ROUTLEDGE ADVANCES IN TRANSLATION STUDIES

Translating Feminism in China

Gender, sexuality and censorship

Zhongli Yu 


\section{Translating Feminism in China}

This book explores translation of feminism in China through examining several Chinese translations of two typical feminist works: The Second Sex (TSS, Beauvoir 1949/1952) and The Vagina Monologues (TVM, Ensler 1998). TSS exposes the cultural construction of woman while TVM reveals the pervasiveness of sexual oppression toward women. The female body and female sexuality (including lesbian sexuality) constitute a challenge to the Chinese translators due to cultural differences and sexuality still being a sensitive topic in China. This book investigates from gender and feminist perspectives, how TSS and TVM have been translated and received in China, with special attention to how the translators meet the challenges. Since translation is the gateway to the reception of feminism, an examination of the translations should reveal the response to feminism of the translator as the first reader and gatekeeper, and how feminism is translated both ideologically and technically in China. The translators' decisions are discussed within the social, historical, and political contexts. Translating Feminism in China discusses, among other issues:

- Feminist translation: practice, theory, and studies

- Translating the female body and sexuality

- Translating lesbianism

- Censorship, sexuality, and translation

This book will be relevant to postgraduate students and researchers of translation studies. It will also interest academics interested in feminism, gender studies and Chinese literature and culture.

Zhongli Yu is Assistant Professor of Translation Studies at the University of Nottingham Ningbo China (UNNC). 


\section{Routledge Advances in Translation Studies}

1 Applying Luhmann to Translation Studies

Translation in Society

Sergey Tyulenev

2 Interpreting Justice

Ethics, Politics and Language

Moira Inghilleri

3 Translation and Web Searching

Vanessa Enríquez Raído

4 Translation Theory and Development Studies

A Complexity Theory Approach

Kobus Marais

5 Perspectives on Literature and Translation

Creation, Circulation, Reception

Edited by Brian Nelson and Brigid Maher

6 Translation and Localisation in Video Games

Making Entertainment Software Global

Miguel Á. Bernal-Merino

7 Translation and Linguistic Hybridity

Constructing World-View

Susanne Klinger

8 The Dao of Translation

An East-West Dialogue

Douglas Robinson

9 Translating Feminism in China

Gender, Sexuality and Censorship

Zhongli $\Upsilon u$

10 Multiple Translation Communities in Contemporary Japan

Edited by Beverley Curran, Nana Sato-Rossberg, and Kikuko Tanabe 


\section{Translating Feminism in China}

Gender, sexuality and censorship

\section{Zhongli Yu}


First published 2015

by Routledge

2 Park Square, Milton Park, Abingdon, Oxon OX14 4RN

and by Routledge

711 Third Avenue, New York, NY 10017

Routledge is an imprint of the Taylor \& Francis Group, an informa business

(C) 2015 Zhongli Yu

The right of Zhongli Yu to be identified as author of this work has been asserted by her in accordance with sections 77 and 78 of the Copyright, Designs and Patents Act 1988.

All rights reserved. No part of this book may be reprinted or reproduced or utilised in any form or by any electronic, mechanical, or other means, now known or hereafter invented, including photocopying and recording, or in any information storage or retrieval system, without permission in writing from the publishers.

Trademark notice: Product or corporate names may be trademarks or registered trademarks, and are used only for identification and explanation without intent to infringe.

British Library Catalogning in Publication Data

A catalogue record for this book is available from the British Library

Library of Congress Cataloging in Publication Data

$\mathrm{Yu}$, Zhongli.

Translating feminism in China : gender, sexuality and censorship / Zhongli Yu. pages $\mathrm{cm}$. - (Routledge Advances in Translation Studies)

Includes bibliographical references and index.

1. Translating and interpreting-China. 2. Gender identity-China. 3. Feminism-China.

I. Title.

P306.8.C6Y8 2015

$418^{\prime} .03305-\mathrm{dc} 23$

2014043522

ISBN: 978-1-138-80431-9 (hbk)

ISBN: 978-1-315-75309-6 (ebk)

Typeset in Galliard

by Graphicraft Limited, Hong Kong 


\section{Contents}

List of tables

Acknowledgements

List of abbreviations

viii

1 Introduction

1.1 Gender, feminism, and translation: Key terms and concepts

1.2 TSS and TVM: Gender, sexuality, and censorship

1.3 Overview of chapters

1.4 Examples, back-translations, strategy terms, and Chinese names and sources

Notes

Bibliography

2 Feminist translation: Practice, theory, and studies

2.1 Feminist approaches to translation

2.1.1 Feminist translation strategies: Flotow's summary

2.1.2 Feminist translation strategies: Massardier-Kenny's redefinition

2.1.3 Feminist translation strategies: Maier's outline

2.1.4 Feminist translation strategies: Wallmach's analysis

2.2 Feminist translation studies: Within and outside China 27

2.2.1 Feminist translation studies outside China 28

2.2.1.1 Feminist translation studies in the 1980s 29

2.2.1.2 Feminist translation studies in the 1990s 29

2.2.1.3 Feminist translation studies in the twenty-first century

2.2.1.4 Sexuality in translation studies 33

2.2.2 Feminist translation studies within China 34

2.2.2.1 Emergence of feminist translation studies in the 1990s

2.2.2.2 Development of feminist translation studies in the twenty-first century 
3 Contextualising the Chinese translations of The Second Sex and The Vagina Monologues

3.1 Le Deuxième Sexe and The Second Sex 59

3.2 Chinese translations of The Second Sex 64

3.3 The Vagina Monologues 68

3.4 Chinese translations of The Vagina Monologues 71

Notes $\quad 76$

Bibliography $\quad 77$

4 Translating the female body and female sexuality in

The Second Sex

4.1 Translating the female body 84

4.1.1 Women's physical appearance $\quad 84$

4.1.2 Women's psychology of their bodies 91

4.2 Translating female sexuality 96

4.3 Summary 103

Notes $\quad 104$

Bibliography 104

5 Translating the female body and female sexuality in The Vagina Monologues

5.1 Translating 'vagina' 106

5.2 Translating sexual violence 119

5.3 Translating misogyny 124

$\begin{array}{lll}\text { 5.4 Summary } & 128\end{array}$

$\begin{array}{ll}\text { Bibliography } & 129\end{array}$

6 Translating lesbianism in The Second Sex and The Vagina Monologues

6.1 Lesbianism in the Chinese translations of The Second Sex

6.2 Lesbianism in the Chinese translations of The Vagina Monologues 141

6.2.1 'The vagina workshop' 142

6.2.2 'The Little Coochi Snorcher That Could' 146

6.2.3 'The Woman Who Loved to Make Vaginas Happy' 150

6.3 Summary 153

Note 154

Bibliography 154 
7 Censorship, sexuality, and translation 158

7.1 Censorship, translation, and translation publishing $\quad 158$

7.2 Translation publishing from 1980 to $2009 \quad 162$

7.2.1 Revival and fluctuation from 1980 to $1989 \quad 163$

7.2.2 Depression and reformation from 1990 to $1999 \quad 166$

7.2.3 Market-oriented development from 2000 to $2009 \quad 167$

7.3 Censorship of sexuality and the Chinese translations of The Second Sex 167

7.4 Censorship of sexuality, and the Chinese translations of The Vagina Monologues $\quad 172$

$\begin{array}{lll}7.5 & \text { Summary } & 178\end{array}$

$\begin{array}{ll}\text { Notes } & 179\end{array}$

$\begin{array}{ll}\text { Bibliography } & 180\end{array}$

8 Conclusion: Gender, feminism, and translation studies 185

8.1 Gender, translation strategies, and translation effects 185

8.2 Female/male: Essentialism? 188

8.3 Feminist translation studies: Where are we going? 190

Bibliography 193

$\begin{array}{ll}\text { Index } & 196\end{array}$ 


\section{List of tables}

2.1 Number of dissertations on women/gender/feminism and translation (2004-2014)

2.2 Number of journal articles on women/gender/feminism and translation (1996-2014) 36

4.1 Number of times the strategies are used (TSS, Examples 1-16, 24 cases)

5.1 Number of times the strategies are used (TVM, Examples 1-14, 18 cases)

6.1 Number of times the strategies are used (TSS, Examples 1-11, 14 cases)

6.2 Number of times the strategies are used (TVM, Examples 12-18, 9 cases) 


\section{Acknowledgements}

I am grateful to the University of Manchester and the University of Nottingham Ningbo China for the funding that enabled me to conduct this research and present it at international conferences.

Special thanks go to Dr James St André for suggesting that I study translations of The Second Sex and Dr Şebnem Susam-Sarajeva for encouraging me to study translations of The Vagina Monologues. I am grateful to Dr James St André, Dr Chen Jianbo, Professor Margaret Littler, Dr Wei-hsin Lin, and Dr Keekok Lee for their repeated reading and proofreading, invaluable and insightful feedback and advice, continual encouragement, and help when difficulties arose.

Thanks go to other CTIS staff and colleagues at the University of Manchester for their comments on my research. In particular, I am grateful to Professor Mona Baker for her help, advice and encouragement throughout this research, especially at the revision stage. Thanks go to IC colleagues at the University of Nottingham for sharing my work when I was on academic leave for this book. I am especially grateful to the Dean of Education and Humanity Professor Fintan Cullen and the Head of School of International Communications Professor Adam Knee for their kind help in creating favorable conditions for my research leave.

Thanks go to Dr Cosima Bruno, Dr David Laven, and the blind reviewers for their critical comments and suggestions for revision. Thanks go to all those who gave me feedback on my presentations at international conferences. Particularly, I am grateful to Professor Sherry Simon and Professor G. C. Spivak for their positive responses at the 2013 Nida School of Translation Studies in Italy. A special word of thanks also to Christina Low, Aletheia Heah, Yuvaneswari Yogaraja, and other editorial staff at Routledge for their contribution to the publication of this book.

Last but not the least, I must thank my family and friends who have supported or helped me over the past few years in various ways so that I can enjoy and accomplish my research in the UK and complete revision of my manuscript in Ningbo. I am most grateful to my husband and parents for their love, inspiration and support. 


\section{List of abbreviations}

Ai: Ai Xiaoming; in the examples, translation by Ai Xiaoming and her students Chen: Chen Cangduo; in the examples, translation by Chen Cangduo

LDS: Le Deuxième Sexe

Li: $\quad$ Li Qiang; in the examples, translation by Li Qiang

S/N: Sang Zhuying and Nan Shan; in the examples, translation by Sang Zhuying and Nan Shan

ST: $\quad$ source text

Tao: Tao Tiezhu; in the examples, translation by Tao Tiezhu

TSS: The Second Sex

TT: target text

TVM: The Vagina Monologues

W/Q: Wang Youqin and Qiu Xichun, et al.; in the examples, translation by Wang Youqin and Qiu Xichun, et al.

Yu: Yu Rongjun; in the examples, translation by Yu Rongjun 


\section{Introduction}

Translation is a cross-cultural as well as cross-lingual activity, involving more than linguistic considerations, especially when the source culture is geographically and/or temporally distant from the target culture. Since the 1980s, translation studies has gradually turned to culture, taking the study of the process and product of translation not just 'as a linguistic phenomenon', but also 'as a form of intercultural mediation located in a specific sociocultural and ideological setting' (Munday 2006: 195); at the same time moving from prescriptive to descriptive methodology, paying more attention to what translators do in their translations than what translators should do to produce a good or correct translation. The concept of linguistic equivalence has gradually given way to the 'cultural turn' (Bassnett and Lefevere 1990), and broader issues, such as context, conventions, and history of translation have attracted growing attention (Bassnett and Lefevere 1998). The cultural turn in translation studies 'prepared the terrain for a fruitful encounter with feminist thought' (Simon 1996: 8). Feminist translation theory nourished the renewal of scholarly interest in translation from the 1990s, giving fresh impetus to the 'cultural turn' of translation studies for its discourse (Lefevere 1992). Feminism allows translation to be viewed as a form of re-writing within a specific historical, social, and cultural context, a re-writing that always implicates the translator's subjectivity. Translators can 'use language as cultural intervention, as part of an effort to alter expressions of domination, whether at the level of concepts, of syntax or of terminology' (Simon 1996: 9). Such a view conflates writing with translation and challenges the long dominant theory of translation as creating some kind of equivalence of fixed meaning (Flotow 1996).

Western feminist translation and its studies emerged decades ago. What is going on now? At 2013 Nida School of Translation Studies, I asked the 2013 Nida School professor Sherry Simon whether feminist translation as a practice was still going on in Canada. Her answer was no, because people were interested in other things now. In her edited book Translating Women (2011), Luise von Flotow proposes returning to feminist theory in translation. We may ask, what has happened in (Western) feminist translation studies since its inception in the 1980s? Where is it going? Feminist translation studies started to appear in China in the late 1990s. Since then, nearly two decades have passed, what trajectory 


\section{Introduction}

has it followed? What are the major concerns? Are the concerns similar to or different from what has been discussed in the West? Does feminist translation happen in China? If yes, in what way, and how similar to or different from the Canadian feminist translation, especially in terms of translation strategy? I am trying to address these (and other questions) in this book, with an examination of several Chinese translations of two typical feminist works: The Second Sex (TSS) by Simone de Beauvoir (1949/1993) and The Vagina Monologues (TVM) by Eve Ensler (1998). There have been efforts to draw a European map of feminist translation studies (Federici and Leonardi 2013). In this book, I venture to paint a larger picture of feminist translation studies outside China, mainly in the West, in order to sketch the trajectory of Chinese feminist translation studies. ${ }^{1}$ The global and local pictures will set the scene for the two case studies. As José Santaemilia says, Chinese feminist translation studies is 'an area practically unknown' to the world (Santaemilia in Santaemila and von Flotow 2011: 24). This book is an effort to fill the lacuna. It is also hoped that when each culture has its own map of feminist translation studies drawn, a world map will be formed.

\subsection{Gender, feminism, and translation: Key terms and concepts}

It has been noted that translation was an important motor for Anglo-American and various feminisms (Flotow 2012: 129). Chinese feminism is another case in point. This book studies translating feminism in China through an examination of Chinese translation of two feminist works from a feminist position. To do this, a brief account of the key terms and concepts used in this study is in place, such as gender, feminism (Western and Chinese), feminist translation, and feminist translation studies, which unfolds the connections and interactions between gender, feminism, translation, and translation studies. These key terms and concepts not only constitute the theoretical context for this study, but in a degree exhibit the historical context of TSS and TVM and their Chinese translations, providing useful background information for analysing the translations.

Gender includes grammatical gender, i.e. 'the grammatical practice of classifying nouns as masculine, feminine or neuter' (Glover and Kaplan, 2000: xi), and social gender, i.e. 'ways of seeing and representing people and situations based on sex difference' (Goodman 1999: vii). Previously used primarily in grammatical and literary contexts, the term gender became current in sexology in the early 1960s (Glover and Kaplan 2000: xix), and was taken over by American feminists in the 1970s to define sex in a social sense (Widerberg 1998: 134). Gender takes masculine and feminine attributes as highly cultural and contingent, leaving human sexual (reproductive) dimorphism basically unchallenged (Hawthorne 2000: 6). Well before the word 'gender' was used to refer to the social and cultural aspects of sexual difference, Beauvoir had proposed this notion in her famous book Le Deuxième Sexe (LDS) [The Second Sex], although the French language does not distinguish between sex and gender. Her aphorism on the social construction of femininity that 'on ne nait pas femme, on le devient' [one 
is not born, but rather becomes a woman] has become well-known and has been quoted worldwide (Beauvoir 1949/1976: 13). In Judith Butler's theory of gender performativity, gender, like theatre performance, is performed without one being conscious of it, representing an internalised notion of gender norms. It is important to undo the restrictively normative conceptions of sexual and gendered life to have more possibilities of living (see Butler 1999 and 2004).

The concept of gender was 'most clearly introduced to China by Chinese diasporic feminists from 1993 onward' and was 'further popularized with the "gender mainstreaming" mandate of the Beijing Conference' (Xu Feng 2009: 203). There have been two Chinese terms for gender: 社会性别 [social gender/ sex] and 性别 [gender/sex], representing two different interpretations of gender and also 'the complex interactions and contradictions between feminisms of various origins'. The translation of gender as ‘社会性别' [social gender/sex] is supported by a 'universalist rhetoric', especially by Chinese diasporic feminists (such as Wang Zheng) and those who have received education in the West. With '社会' [social] being added to '性别' [gender/social], the term stresses the social and constructed nature of gender roles, and breaks away from essentialist definitions of women's roles, displayed in calls for femininity in the feminism of the 1980s and in contemporary commodity culture which instrumentalizes a traditional concept of femininity'. In that case, gender can be used as an analytical weapon to 'fight the myriad manifestations of patriarchy in Chinese society'. To some other Chinese scholars (such as Li Xiaojiang), '性别' [gender/sex] is a better choice, because it refers to both sex and gender roles. In their opinion, it is redundant to add 'social' to a concept that is social in the first place. The added 'social' not only over-emphasises women's and men's social roles, but also ignores the physical differences between the sexes, which is actually another form of women's self-denial, reminding people of the Maoist concept of identical gender roles. They believe that '性别' [gender/sex] represents a 'truly indigenous concept' or 'contextualized concept', reflecting the 'particularity' of Chinese feminism. The trouble in translating gender into Chinese presents an example of 'troublesome intercultural encounters', and somewhat reveals the complex process of reception of Western feminism, a mix of both acceptance and rejection (Spakowski 2011: 34-35; also see Xu Feng 2009).

Feminism has been a 'troublesome' term due to its complexity and diversity (Beasley 1999: ix). To put it simply, feminism is 'a recognition of the historical and cultural subordination of women (the only worldwide majority to be treated as a minority), and a resolve to do something about it' (Goodman 1999: x). Feminism has been regarded as 'innovative, incentive and rebellious' (Beasley 1999: 3). There have been many feminisms (Poovey 1988: 51). The history of feminism is commonly divided into three waves (see Krolokke 2005, Rampton 2008), though some feminists do not see the wave metaphor as a helpful way to understand stages in feminist history (Howie 2007: 283). The first covers the late nineteenth and early twentieth centuries and its agenda appeared to be largely political in nature, either from a liberal or socialist point of view. The 


\section{Introduction}

activities and writings of the suffragette movement are typical of this wave. The second is said to emerge during the 1960s to the 1980s, often referred to as radical, in particular, concerned with the rights of oppressed minorities such as lesbians, women of colour, women of the developing countries, etc., under the general slogan 'The personal is political'. The third wave, emerging from the mid-1990s, is more oriented to diversity, multiplicity and even ambiguity in women's lives. In Europe, this is referred to as 'new feminism', concerning itself with issues such as trafficking, violence against women, pornography, etc., while theoretically undermining the earlier notion that there can be 'universal womanhood'. In some cases, the women even shun the very label 'feminists' to characterise themselves, rejecting the dichotomy of 'us and them'. Some thirdwavers claim the writings of feminists of colour from the early 1980s as the beginning of the third wave (Heywood and Drake in Snyder 2008: 180). ${ }^{2}$

However, the three waves should not be understood to be independent of each other. The first two waves do not stand for rigid boundaries in attitude, content or dates. For instance, Mary Wollstonecraft's A Vindication of the Rights of Women, Virginia Woolf's A Room of Her Own, as well as Beauvoir's TSS, may all be said to be iconic texts of the first wave of feminism. Yet, Wollstonecraft's book appeared as early as 1792 (just after the French Revolution), fighting under the liberal flag of political rights; Woolf's in 1929 (between the two World Wars), introducing the notion of female bisexuality as well as pleading for women's unique voice in writing; and Beauvoir's in 1949 (just after the Second World War), critiquing patriarchy and the 'otherness' of women. TSS, together with Betty Friedan's work The Feminine Mystique (1963), has also been regarded as 'opening the second wave feminism' (Min Dongchao 2005: 279). The third has been thought to be a continuation of the second wave as well as a response to the failures of the second. It continues to emphasise personal experiences, but reject the universal claim that all women share a set of common experiences (Snyder 2008: 184, 186). Some people regard the third wave as just another way of talking about the contemporary moment, while some others prefer calling it post-feminism. Post-feminism literally means 'after feminism' or what has been 'left when feminism is over'. Open to many different, conflicting, and problematic interpretations, on the one hand, post-feminism seems to connote that feminism is in a mess, in decline, and has failed (Showalter in Gillis et al. 2007: 292). TVM is regarded as a 'post-feminist' work (Dapkunaite in Khanna 2007).

Feminist translation is closely related to the 'shift of attention from "androtexts" (books by men) to "gynotexts" (books by women)' in the late 1970s (Showalter in Barry 2002: 123). Specifically, feminist translation emerged from translating experimental feminist writing, the radical feminist writing of the 1970s in Western Europe and North America. Experimental feminist writing resulted from Hélène Cixous's call for écriture féminine (literally 'gendered women's writing') (Baldick 1990: 65), or 'feminine writing' (Moi 1985: 108), aiming at inscribing femininity as a resistance to phallogocentric writing, or masculine writing. As women had been 'marginalized, silenced and repressed in the masculine symbolic order', feminists experimented to produce feminine texts 
in an 'other' language, i.e. to 'produce discursive spaces, in and from which feminine difference and desire may be creatively articulated' (Guild 1992: 74-76). An important theme in experimental feminist writing is the 'objectified, obscured, vilified or domesticated' female body (Flotow 1997: 17), because women have historically and stereotypically been described as sexual objects for men (virgins or prostitutes, wives or mothers), and have been prevented from expressing their sexuality in itself or for themselves (Jones 1981: 362). By writing herself, woman's body can be heard and the immense resources of the unconscious will spring forth (Cixous 1975: 250). Hence, women must write through their bodies and invent the impregnable language to wreck partitions, classes, rhetorics, regulations, and codes (Cixous 1975: 256).

In 'writing the body' or 'writing through the body' (Guild 1992: 74-75), feminists found existing language inadequate to describe the female body. In a patriarchal society, language is created by and for men. Patriarchal language often fails to speak of women's experiences. Feminists also found that the patriarchal language was an instrument of women's oppression and subjugation because it determined to a large extent what women could think and write. This resulted in feminist experimentation in language by exploring new ground, seeking to develop new ideas and a new language for women. Radical feminists even tried to create new words, new spellings, new grammatical constructions, new images and metaphors to undermine, subvert, or even destroy the conventions of patriarchal language (Flotow 1997: 14-17) and the dominant discourses of cultural formation and authority (Chamberlain 1998: 96). Feminism as 'a discourse of emancipation' has caused problems to both readers and translators (Niranjana 1998: 134). Experimental writing in new language with new syntactic structures is very difficult to read and even more difficult to translate. Many of them need 'mediation' (criticism and explanation) within the source language and culture before they can be understood. The neologisms, word plays, puns, and other linguistic and formal innovations in 'writing through the body' require innovative ways to respond to the 'resulting technical and theoretical challenges'. This led to feminist translation practices, and the translator's role became 'overtly political' (Flotow 1997: 10-24). ${ }^{3}$ In Chapter Two, there will be more discussion about feminist translation.

Feminist translation studies resulted from feminist translation practices. Feminist writing brought gender issues into language, which has dramatically raised the gender awareness of translators. This can be clearly identified in translating women's writing in Canada in the late 1970s. Feminist translators' discussions of their own translations in translator's prefaces and essays led to wider scholarly interest in feminist translation. Gender issues in translation, including grammatical gender and social gender, became topical in translation studies. Gender as a concept and an analytical category entered the field of translation studies in the 1980s (Flotow 2009), and has advanced feminist translation studies. Early discussions of feminist approaches to translation in the 1980s in North America were soon echoed in Europe, and a feminist school of translation theory emerged. The attention to gender issues gradually extended to include 'gay' and 'sexuality' 
as new analytical categories. Sexuality refers to the 'linguistic representations of sexual practices' (Flotow 2009). Sexuality in feminist studies usually focuses on women, referring to 'the psychosexual as well as the biological aspects of female sexual existence, [...] the interaction between desire and the body' (Moi in Flotow 2000: 16). As a currently developing analytical category in translation studies (Larkosh 1996), sexuality addresses issues such as forms of censorship (such as self-censorship by the translator or editor and censorship by the institute) imposed on representations of sexuality in translation (Flotow 2009). With the involvement of Judith Butler's notion of gender performativity and queer theory, feminist translation studies seem to be expanding to broader areas, while it is also noted that queer theory has led to 'a notable decline in research relating to women and translation', in spite of the generated 'discursive solution to problems of essentialism and identity politics that plagues feminisms' (Flotow 2012: 131). Gender did not become an analytical category in Chinese (feminist) translation studies until the twenty-first century, 20 years behind the West, and much remains to be explored, such as (homo)sexuality and censorship concerning (homo)sexuality (see Chapter Two for more discussion about feminist translation studies within and outside China).

Chinese feminism is no less difficult to define, due to its linguistic and conceptual ambivalence and controversy (Ko and Wang 2006: 463). Feminism was not indigenous but imported from the West. Integrated with local reality, Western feminism was gradually translated into Chinese feminism, a term which seems to have become current since the late 1990s. The birth of Chinese feminism was 'an event of global proportions' at the turn of the twentieth century (Liu et al. 2013: 4-6). Feminism was introduced to China through Japan during the period of the May Fourth Movement (1915-1921), a political, social, and cultural revolution with the women's movement as a part of it. Chinese intellectuals adopted 'a Western view of history' and endeavoured to 'awaken' Chinese women to 'break from the traditional Confucian highly unequal social relation of men and women'. Arranged marriage was condemned, and young people got the right to choose their own marriage partners. The custom of bound feet was denounced, and the 'new' women were to be educated just like their brothers. Chinese women's liberation movement at this stage was an integrated part of anti-imperial and anti-feudal revolution, and therefore, feminism at this time was translated into '女权主义' [women's rights-ism/ power-ism], a term adopted from Japanese translation of feminism, to reflect the political desires and demands of feminists (Min Dongchao 2005: 274-275, Xu Feng 2009: 203). The spirit of the May Fourth Movement flowed and ebbed, and the feminist movement declined in the decades to come.

From the establishment of the People's Republic of China in 1949, Chinese feminism has been a 'state policy' to 'mobilize rural and urban women into the public sphere' (Barlow 2001: 1288). As an important aspect of socialistic revolution and construction, Chinese feminism is called 'socialist feminism' (Chen 2003: 278, He Ping 2009). During the Cultural Revolution (1966-1967), 'Maoist ideology of gender equality'_'Woman can hold up half the sky'- 
masculinised rather than emancipated women (Schaffer and Song 2007: 19). From 1949 to the end of Cultural Revolution, China turned inwards on the whole, and writings from the capitalist West became unavailable to the ordinary educated people. Western feminism re-entered China in the 1980s when China adopted open policy. The 'movement towards the liberation of thought' and economic reform after the Cultural Revolution increased women's self-awareness. A collective feminist consciousness arose among Chinese women, with growing recognition of gender differences and inequality. As China started to shift from 'state-socialism' to 'market-socialism', Chinese women were found to become 'more vulnerable', 'more frequently turned into sexual objects, and exploited and discriminated against in employment contexts'. The differences between men and women had to be re-emphasised to 'justify inequalities that came with economic reform' (Min Dongchao 2005: 275-276). At this stage, Chinese feminism showed an enthusiastic "return to a female identity or "female essence" (nüxing qizhi)' (Zhong Xueping 2006: 637).

With the proliferation of feminism in China, the previous translation of feminism as '女权主义’ [women’s rights-ism/power-ism] became unsatisfactory and now is often a 'derisive term' in China, as it implies the stereotype of a 'man-hating he-woman hungry for power' and is usually related to 'more Western-oriented, politically-based oppositional feminism'. In the 1990s, the new translation of feminism as '女性主义' [women's gender-ism/feminine-ism, womanism] replaced the old one, 'to describe the orientation of the Chinese women's movement' and 'to distinguish Chinese from western feminism' (Ko and Wang 2006: 463, Min Dongchao 2007: 181, Schaffer and Song 2007: 20, Xu Feng 2009: 203). Women's gender-ism/feminine-ism sounds 'less threatening' and thus 'enjoys more purchase' due to its 'semantic flexibility'. This 'softer' feminism would hardly be regarded as feminist according to the Anglophone standard, since it sounds like 'promoting femininity' and 'reinforcing gender distinctions' (Ko and Wang 2006: 463). Now it refers to 'new cultural strategies and attitudes towards women in the twenty-first century' and signifies a " smiley" or friendly/complimentary Chinese-styled feminism' (Schaffer and Song 2007: 20). Contemporary Chinese feminism is regarded as being 'sharp but not aggressive' and concerned with 'the harmonious development of both sexes' (Huang Lin in Schaffer and Song 2007: 20). This feature can be seen in the Chinese translators' strategies in translating TSS and TVM in China. The implications behind the two Chinese terms for feminism reflect a 'pluralist and complex feminism in China, which does not fit the formula of "difference within commonality" put forth by international feminism' (Spakowski 2011: 47). The very brief account of Chinese feminism here shows a short history, or the development of Chinese feminism, which also represents a process of reception of Western feminism in China. It helps contextualise the issues to be discussed in Chapters Four to Seven and the reception of TSS and TVM. The study of the Chinese translations of TSS and TVM actually presents two cases of reception of Western feminism in China, because 'the history of its local reception is a history of the politics of translation' (Ko and Wang 2006: 463). 


\section{Introduction}

\subsection{TSS and TVM: Gender, sexuality, and censorship}

TSS is a complex academic work with a pivotal analysis of women's oppression by men, exposing the cultural construction of woman. TVM is a bold feminist dramatic work of 'body writing', which tells (un)happy stories of women's sexualities and eroticisms, especially women's relationships with their vaginas. It reveals the pervasiveness of sexual oppression toward women. Both works concern the female body and female sexuality, which have been at the centre of feminist theory, because these often reflect a 'tension between women's lived bodily experiences and the cultural meanings inscribed on the female body that always mediate those experiences' (Conboy et al. 1997: 1). TSS and TVM are not experimental in language; however, both texts highlight the female body and female sexuality that have produced and/or are still producing shock among Chinese readers. The descriptions of the female body, female sexuality, and lesbianism do constitute a challenge to the Chinese translators due to cultural differences and sexuality (homo or hetero) being a 'taboo' topic in China (Lung 2003, Xinran 2005 and 2008). Particularly, the various terms for vagina (mostly slang and vernacular or area-specific terms) and graphic descriptions of female masturbation and same-sex love in TVM make it very challenging for translators from other linguistic, cultural, and ideological backgrounds. Marisa Demarco's remark reveals to some extent the difficulty for translation: 'It's hard to imagine how you might say “coochi snorcher” in Korean' (Demarco 2003). Of course, Demarco is not simply referring to Korean, but to any foreign language.

In China, sexuality has been liberated and repressed by turns in history (Jeffreys 2006). Sexual descriptions, including very erotic and vivid ones, can be seen in pre-modern and early-twentieth-century literary works, such as 金瓶梅 [The Plum in the Golden Vase, also known as The Golden Lotus], a Chinese naturalistic novel composed in the late Ming Dynasty (1368-1644), which contains a graphically explicit depiction of sexuality. However, in the Qing Dynasty (1644-1910), governmental authorities viewed sex 'as something potentially dangerous to the rule of a strong centralizing state' and prohibited representations of sex in the realm of literature and culture. The prohibition gradually 'intensified' as time progressed, but was 'relaxed' in the May Fourth era (Sigley and Jeffreys 1999: 52) when sexuality was openly discussed (Sang 2003: 26). The 1950s were a time of puritanical silence, and in the three decades from the 1950s, discourses on sexuality were subject to stringent ideological controls. Open policy in the 1980s brought 'unfettered' liberatory conversation on sexual matters (Evans 1997, Ruan Fang-fu 2007). The sexologist Pan Suiming, on the one hand, declares that "the subject of "sex" is no longer "taboo"', while, on the other hand, admitting that 'the subject of sex is still a rather delicate and controversial topic' in China (Sigley and Jeffreys 1999: 50-51, my emphasis). In contemporary China, governmental authorities are as much implicated in the creation of new spaces for public discussion of sexual behaviour and mores as they are involved in the control of sexual discourse (Jacka 2007). Several incidents in 2003 have indicated 'how much sex matters 
to the authorities, and how prepared they are to intervene in it': a couple was arrested for watching a pornographic DVD in their bedroom, a university student was expelled for becoming pregnant through premarital sex, and Beijing's first 'sex culture' museum was closed hours after the opening ceremony (McMillan 2006: 128). Chapter Seven has a detailed discussion of censorship of sexuality in China.

In such circumstances, TSS and TVM have had very different experiences in their circulation in China. Since its arrival in China in the 1980s, with eight Chinese translations being published, TSS in general has been well received by the authorities, intellectuals, and general public, and has established itself in academia as an important text on the reading list for university students of philosophy, comparative studies, and gender/women studies. In contrast, the reception of TVM in China has not been that smooth. Up to now, three Chinese translations can be found: one Taiwan translation and two Mainland versions. Unfortunately, the Taiwan translation is not circulated in the Mainland. None of the two Mainland translations has been published in book form, only available on the internet, and no commercial productions of the play were permitted before 2009. Public performance finally gained permission in 2009 but encountered resistance from the public in March 2010 when it toured to Shenzhen, a special economic zone and a supposedly open metropolis. Access to TVM has been mainly through the internet and amateur productions by students. It has been used as an important case study in some universities (such as Sun Yat-sen University, Fu Dan University, Xiamen University, and Beijing Normal University) for students of comparative studies and gender/women studies, and used by sexologists for sexual education (see Chutian Jinbao 2006, aibai.cn 2006).

Well received or not, studies of the Chinese translations of TSS and TVM are hardly seen. As mentioned above, TSS is a complex academic work. It might look daunting to study translation of such a big work. As a matter of fact, studies of translation of academic books are not often seen, at least in China. TSS (and other Western theoretical books) has been read and quoted as if it was written in Chinese. TVM is both linguistically and culturally challenging due to its sexual content. Over the years, I have kept asking my MA students in translation studies whether they would translate TVM if they were approached by a publisher. Reading a monologue like 'Hair' given to them, the students' first responses were almost all the same every year. They all looked greatly shocked, very much embarrassed, and too shy to look at each other, with their eyes downcast. Some students told me in their reflective journals that their heartbeat became faster when reading the monologue. Hence, many students, especially female students, firmly stated that they would not translate TVM if approached by the publisher, because if they were to translate it, their reputation would be undermined and they would be considered as having loose morals. ${ }^{4}$ In 2006, an editor of a translation studies journal in China warned me not to touch such sexually sensitive material and said that research on it would not get published because they did not accept papers on sexually and politically sensitive issues in order not to bring trouble to the journal. It is no wonder that sexuality has not 
become an analytical category in Chinese (feminist) translation studies (see 2.2.2.2).

A line-by-line, paragraph-by-paragraph, and page-by-page initial comparison of the Chinese translations of TSS and TVM discloses differences at both lexical and sectional levels. To be specific, the differences between the translations manifest themselves mainly in translating descriptions of the female body and female sexuality. A rough comparison of the differences gave an impression that there seemed to be 'woman translation' and 'man translation', i.e. the women almost translate in the same or similar way while the men also do the same. This generated a question of the relationship between the translation differences and gender identities of the translators. This prompted me to examine the translation strategies used in the Chinese translations of TSS and TVM. The sentences or sections that contain obvious differences roughly fell into three categories: descriptions of the female body, of female heterosexuality, and of female same-sex sexuality, with lesbianism being censored to some degree. This intimates that gender, sexuality, and censorship are the major issues in translating TSS and TVM. These issues will be addressed through two levels of analysis of the translations in question: micro/textual level concerning lexical choices and sectional rewriting, and macro/social level concerning 'para-translation' factors, including the social, historical, and political factors. The textual analysis focuses on the strategies used by the translators (as cultural mediators rather than mere wordsmiths) in dealing with the descriptions of the female body and female sexuality, and the effects of the strategies that will be discussed from a feminist position. It has been noted that ' $[t]$ ranslating the language of love and sex is a political act, with important rhetorical and ideological implications, and is fully indicative of the translator's attitude towards existing conceptualisations of gender/sexual identities, human sexual behaviour(s) and society's moral norms' (Santaemilia 2014: 104). Since 'the reference to love, sex and intimacy was powerful enough to provoke important translation effects' (Santaemilia 2014: 106, also see Flotow 2000), focusing on translating the female body and female sexuality, 'a contested site- a battle ground for competing ideologies', can better reveal the translators' manipulations in translating feminism and reception of Western feminism in China (Conboy et al. 1997: 7).

In translation studies, there have been two tendencies. Traditional translation studies were preoccupied with language issues, often concerned with translation of words or sentences, with isolated or even invented examples. Little research examines the whole presentation of a translation. Since the cultural turn, more complex issues have being included in translation studies. In recent years, there seems to be a tendency that attentions are being drawn away from language issues in translated works, and translation studies do not really study the translated work per se, i.e. ignoring carefully studying specific translations or even disdaining to do that. A translation is first of all a piece of language work. No word in the translated work is neutral, and no word choice is innocent, especially those concerning the female body and female sexuality. In this study, the translators' performances are examined with the support of plenty of examples. That 
is to say, this study is solidly based on real translation practices, rather than just citing a few examples from different works as seen in many existing studies. This research pays attention to both language and culture, not only studying the textual representations of TSS and TVM, but also trying to delineate the social, historical, and political contexts behind the representations. In other words, language issues are the starting point for digging deeper into the social, historical, and political background that informs or even determines the formation of the translations or the translation strategies. In particular, it relates the textual representations, especially the censorship concerning (homo)sexuality, to the ups and downs of the translation publishing industry. Such research has rarely been seen.

\subsection{Overview of chapters}

This book consists of eight chapters. In Chapter Two, I first review the major Canadian feminist translation strategies discussed from different points of view by four researchers, namely Luise von Flotow (1991), Françoise MassardierKenny (1997), Carol Maier (1998), and Kim Wallmach (2006). Feminist translation strategies have been an important topic in feminist translation studies, especially at the early stage. In this book, they serve as an object of reference in my examining the strategies adopted by the Chinese translators in their translations of TSS and TVM. Then I investigate feminist translation studies within and outside China and sketch the trajectories of the emergence and development of feminist translation studies within and outside China. As a result, two pictures of feminist translation studies are painted: a global one and a local one. From the two pictures, we can easily locate where we are in feminist translation studies, in which the significance of this study unfolds.

Chapter Three introduces the English source texts TSS and TVM, their Chinese translations, and the Chinese translators. It looks into the themes, text types, and natures of TSS and TVM, and the controversies over TSS and TVM, especially the controversies over Howard M. Parshley's English translation of TSS. In this chapter, the paratranslation factors are explored as much as possible, such as the linguistic/cultural/social identities, age, education, and other background of the translators, the translators' motives for translation, and their translation ideologies. All these factors play a role in the translator's decisionmaking process and the formation of the translation. Another important aim is to find out the source text of each translation for the textual analysis, because none of the translations clearly indicate the source text, while both TSS and TVM have actually different versions, which are not completely identical at all. This chapter lays ground for the textual and social analysis of the Chinese translations of TSS and TVM in Chapters Four, Five, Six and Seven.

Chapter Four scrutinises the strategies the Chinese translators use to deal with the descriptions of the female body and female (hetero)sexuality in TSS and discusses from feminist perspective the effects of the strategies. Four Chinese translations of TSS that include Beauvoir's detailed discussion of the female body 


\section{Introduction}

and female sexuality are compared, two by female translators and two by male translators. The analysis of the lexical choices reveals similarities between the translations by the female translators and between the translations by the male translators, but differences between the translations by the female and male translators. The analysis of the selected examples presented in the chapter and many more similar examples not presented in the chapter indicates that there is indeed a gender gap in their word choices, which produce different effects in representing Western feminism.

Chapter Five parallels Chapter Four. It examines the strategies the Chinese translators use to deal with the descriptions of the female body and female (hetero)sexuality in TVM and discusses from feminist perspective the effects of the strategies. The analysis of the lexical choices and sectional rewritings in all the three existing Chinese translations of TVM (one by a female translator and two by male translators) reveals similarities between the translations by the male translators, and differences between the translations by the female and male translators. Gender gap also exists in their word choices and sectional rewritings, which produce different effects in representing Western feminism. The analysis even shows some similarities between the strategies used by the male translators of TSS and the male translators of TVM and between the strategies used by the female translators of TSS and the female translator of TVM.

Chapter Six focuses on translating lesbianism in TSS and TVM. Three Chinese translations of TSS (one by female translators and two by male translators) that include Beauvoir's detailed discussion of lesbianism are compared, with one female translators' version excluded, from which the lesbian chapter is completely removed. The strategies the Chinese translators use to deal with the lesbian content in TSS are examined through analysing the lexical choices in the three Chinese translations of TSS. The strategies the Chinese translators use to deal with the lesbian content in TVM are examined through analysing the lexical choices and sectional rewritings in the three Chinese translations of TVM. Similar phenomena are found in this chapter. Gender gap is seen again. Meaningless translation and mistranslation occur in the translations by the male translators, as seen in the examples in Chapters Four and Five. More importantly, the translation strategies used by the female and male translators reveal their different attitudes towards homosexuality.

Chapter Seven addresses the issue of censorship of (homo)sexuality through looking into the social, historical, and political contexts. I start with a discussion of how censorship operates and what the targets of censorship are in China. Then I explore the ups and downs in the translation publishing industry from 1980 to 2009, during which the Chinese translations of TSS and TVM were produced and were, therefore, actually a part of the fluctuations. Homosexuality in China, especially attitudes towards homosexuality, is another important factor in my exploration, so as to explain the censorship of (homo)sexuality exercised in some of the translations. With the social, historical, and political contexts of the translations in question being reconstructed, I go beyond the censorship of (homo)sexuality to reception of the translations and relate them to the social 
needs at particular historical moments and other factors, because censorship to some extent represents a kind of reception, which is influenced by various factors.

In Chapter Eight, on the basis of the analysis in previous chapters, the overall similarities and differences between the Chinese translations of TSS and TVM are summarised and the implications for the reception of Western feminism in China are discussed. It is followed by a short discussion of the issue of essentialism in (feminist) translation studies, with reference to the recent queer approaches to translation, so as to have a better understanding of the value of studying translations by translators of different gender identities. The discussion is illustrated by the experience of the Chinese male translator of TSS from the French original and the feedback on this study from a male audience, which to some extent explain why pointless translation and mistranslation occur in the Chinese translations of TSS and TVM by the male translators. The chapter ends with a discussion of the prospects of feminist translation studies, which is interrelated with the discussion of the issue of essentialism in (feminist) translation studies.

\subsection{Examples, back-translations, strategy terms, and Chinese names and sources}

In Chapter Four, four Chinese translations of TSS that include Beauvoir's detailed discussion of the female body and female sexuality are examined to discuss translating the female body and female (hetero)sexuality: the 1986 translation by Sang Zhuying and Nan Shan, the 1988 translation by Wang Youqin and Qiu Xichun et al., the 1998 translation by Tao Tiezhu, and the 2004 translation by Li Qiang. In Chapter Six, three Chinese translations of TSS that include Beauvoir's detailed discussion of lesbianism are analysed for a discussion of translating lesbianism in TSS, with the one by Wang Youqin and Qiu Xichun et al. excluded because the lesbian chapter is cut in their translation. In the examples analysed, ST stands for the 1993 English source text of TSS, S/N for the translation by Sang Zhuying and Nan Shan, W/Q for the translation by Wang Youqin and Qiu Xichun et al., Tao for the translation by Tao Tiezhu, and $\mathrm{Li}$ for the translation by Li Qiang. The page number is included in the bracket after each example.

All the existing three Chinese translations of TVM are examined in Chapter Five to discuss translating the female body and female (hetero)sexuality in TVM, and examined in Chapter Six to discuss translating lesbianism in TVM: the 2000 translation by Chen Cangduo, the 2003 translation by Yu Rongjun, and the 2003 translation by Ai Xiaoming. Ai Xiaoming is the initiator, organiser, and supervisor of the translation and director of the production. The translation is a product by her students under her supervision. In this study, for the sake of convenience, Ai Xiaoming is made to represent the group of the translators she leads. In the examples analysed, ST stands for the source text, Chen for the translation by Chen Cangduo, Yu for the translation by $\mathrm{Yu}$ Rongjun, and $\mathrm{Ai}$ 


\section{Introduction}

for the translation by Ai Xiaoming (and her students). Unless otherwise indicated, the source text examples are taken from the revised V-Day edition of 2001, which is longer and contains more content than the 1998 first edition.

In Chapters Four, Five and Six, all the key words and phrases in the examples for examination are underlined. Each underlined word or phrase is counted as a case and is numbered and put in parentheses in later references. For instance, in Example 1 of Chapter Four, three underlined words and phrases (i.e. three cases) are discussed: 'rounded', 'invisible', and 'make their display'. In 4.3, the second and third cases (i.e. 'invisible' and 'make their display') in Example 1 are mentioned as ' $1(2-3)$ ', meaning the second and third cases in Example 1. Similarly, 2(1) refers to the first case in Example $2 ; 3(2)$, the second case in Example 3; 7(1-2), the first and second cases in Example 7; and so on and so forth.

In each example, the translations are presented in chronological order. In some cases, additional material from the source text is given in brackets to provide context for the examples. All the selected short passages of the Chinese translations for analysis are translated back into English for non-Chinese speakers to have an idea of the main feature of the Chinese translations. Just as Mona Baker does in her book In Other Words, I have tried to back-translate the selected passages as literally as possible to 'give some insight into aspects of the structure; if not the meaning of the original, but it is never the same as the original'. It should be noted that ' $\mathrm{t}]$ he quality of the English that appears in a given backtranslation is not meant to reflect the quality of the translation itself. [...] the English used in the back-translation is not necessarily correct and is not to be confused with natural English' (Baker 1992/2000: 8 and 9).

The following terms for translation strategies are used in analysing the translation examples: repetition (i.e. the ST meaning is repeated or reproduced in the target text (TT)), attenuation (i.e. the ST meaning is reduced or not sufficiently expressed in the TT due to language, cultural or ideological reasons), amplification (i.e. the meaning in the TT is richer due to language, cultural or ideological reasons), semantic translation (i.e. the translation coveys the deep meaning or the contextual meaning of the ST), literal translation (i.e. the translation coveys the dictionary meaning or the surface meaning, which often fails to convey the ST meaning properly), reversion (i.e. the ST meaning is changed in the TT to mean the opposite), omission (i.e. some word(s)/expression(s)/ section(s) of the ST is omitted in the TT due to language, cultural or ideological reasons), addition (i.e. some $\operatorname{word}(\mathrm{s}) / \operatorname{expression}(\mathrm{s}) / \operatorname{section}(\mathrm{s})$ is added that is not in the ST due to language, cultural or ideological reasons), bilingual translation (i.e. keep the English term and give the Chinese term or explanation in the ST), zero translation (i.e. adopt the English term in the TT without Chinese translation or explanation), adaptation (i.e. changes are made due to language, cultural or ideological differences), and localising (or domestication, i.e. the ST is rewritten with local elements incorporated for better reception in the local context), transliteration (i.e. reproduce the pronunciation of the English term in the TT), and semiotic translation (i.e. translate the English term into a symbol). 
The Chinese names in this book are translated into the standard Chinese pinyin, and their family names are put first according to the Chinese custom. This does not apply to those names which are a mix of Chinese family names and English given names and those which use other pinyin systems than standard Chinese pinyin, such as Cantonese. All translations from the Chinese references are my own unless otherwise indicated. Some Chinese publications have their own English titles, which are presented as the original in this book.

\section{Notes}

1 In this book, 'feminist translation studies in the West' is confined to feminist translation studies published outside China in English. Publications in other languages are not considered due to the scope of this book and my scant knowledge of other languages.

2 For more discussions of the three waves of feminism, see Gerhard 2000, Fixmer and Wood 2005, Spencer 2007, Olson et al. 2008, Snyder 2008.

3 See Flotow's detailed discussion of experimental feminist writing for examples, such as those by Nicolas Brossard and Mary Daly and how their translators deal with the neologisms, puns and other word-play in their writings (Flotow 1997: 14-24).

4 Nonetheless, there have been brave students who were encouraged by the feminist messages in TVM and worked on it for their course essays or MA dissertations (see 2.2.2.2).

\section{Bibliography}

Ai，Xiaoming 艾晓明 (trans.) (2003) 阴道独白 [The Vagina Monologues], http:// smileinwind.bokee.com/2440712.html (last accessed on 31 March 2006).

aibai.cn 爱白网 (2006) ‘中国性健康文化博览会上演《阴道独白》’ [The Vagina Monologues was Performed in China Sexual Health Culture Exposition], www.aibai.cn/info/open. php?id=15111 (last accessed on 5 July 2008).

Baker, Mona (1992/2000) In Other Words: A Coursebook on Translation, Beijing: 外语 教学与研究出版社 [Foreign Language Teaching and Research Press], Routledge.

Baldick, Chris (1990) The Concise Oxford Dictionary of Literary Terms, Oxford and New York: Oxford University Press.

Barlow, Tani E. (2001) 'Globalization, China, and International Feminism', Signs 26(4): 1286-1291.

Barry, Peter (2002) Beginning Theory: An Introduction to Literary and Cultural Theory, Manchester and New York: Manchester University Press.

Bassnett, Susan and André Lefevere (eds) (1990) Translation, History, and Culture, London: Printer.

— (1998) Constructing Culture: Essays on Literary Translation, Clevedon: Multilingual Matters.

Beasley, Chris (1999) What is Feminism?: An Introduction to Feminist Theory, London, Thousand Oaks, New Delhi: SAGE.

Beauvoir, Simone de (1949/1976) Le deuxième sexe II, L'expérience vécue. Paris: Gallimard (112th edition).

_ (1993) The Second Sex, translated and edited by H. M. Parshley, New York: Knopf. Butler, Judith (1999) Gender Trouble: Feminism and the Subversion of Identity, New York and London: Routledge.

- (2004) Undoing Gender, New York: Routledge. 


\section{Introduction}

Chamberlain, Lori (1998) 'Gender Metaphorics in Translation', in Mona Baker (ed.) Routledge Encyclopedia of Translation Studies, Shanghai: Shanghai Foreign Language Education Press, 93-96.

Chen, Cangduo 陈苍多 (trans.) (2000) 阴道独语 [The Vagina Monologues], Taibei: 新雨出版社 [Xinyu Publishing House].

Chen, Tina Mai (2003) 'Female Icons, Feminist Iconography? Socialist Rhetoric and Women's Agency in 1950s China', Gender and History 15(2): 268-295.

Chutian Jinbao 楚天金报 [Chutian Golden Newpaper] (2006) ‘性文化博览会冷清开场 女学生演绎《阴道独白》' [Sexual Culture Exposition Opened Quietly, Female Students Performed The Vagina Monologues], http://dujia.hsw.cn/2006-09/16/content_5742467. htm (last accessed on 5 July 2008).

Cixous, Hélène (1975) 'The Laugh of the Medusa', in Elaine Marks and Isabelle de Courtivron (eds) New French Feminisms, Amherst: The University of Massachusetts, 1980, 245-264.

Conboy, Katie, Nadia Medina and Sarah Stanbury (eds) (1997) Writing on the Body: Female Embodiment and Feminist Theory, New York: Columbia University Press.

Demarco, Marisa (2003) 'Dare You to Say "Vagina": Eve Ensler's Acclaimed "Vagina Monologues" Swing by Santa Fe This Week', Culture, http://media.www.dailylobo. $\mathrm{com} / \mathrm{media} /$ storage/paper344/news/2003/02/06/Culture/Dare-You.To.Say. vagina-362294.shtml (last accessed on 11 August 2008).

Ensler, Eve (1998) The Vagina Monologues, New York: Villard.

— (2001) The Vagina Monologues: The V-Day Edition, New York: Villard.

Evans, Harriet (1997) Women and Sexuality in China: Dominant Discourses on Female Sexuality and Gender Since 1949, Cambridge: Polity Press.

Federici, Eleonora and Vabessa Leonardi (eds) (2013) Bridging the Gap Between Theory and Practice in Translation and Gender Studies, Newcastle: Cambridge Scholar Publishing House.

Fixmer, Natalie and Julia T. Wood (2005) 'The Personal is Still Political: Embodied Politics in Third Wave Feminism', Women's Studies in Communication 28(2): 235257.

Flotow, Luise von (1991) 'Feminist Translation: Contexts, Practices, Theories', TTR 4(2): 69-84.

(1996) 'Translation Praxis, Criticism and Theory "au feminin"', Etudes Canadiennes/ Canadian Studies: Revue Interdisciplinaire des Etudes Canadiennes en France 22(41): 181-194.

- (1997) Translation and Gender: Translating in the 'Era of Feminism', Manchester: St Jerome.

_ (2000) 'Translation Effects: How Beauvoir Talks About Sex in English', in Melanie C. Hawthorne (ed.) Contingent Loves. Simone de Beauvoir and Sexuality, Richmond, VA: Virginia University Press, 13-33.

_ (2009) 'Gender and Sexuality', in Mona Baker and Gabriela Saldanha (eds) Routlege Encyclopedia of Translation Studies (2nd edition), London: Routledge, 122-126.

- (ed.) (2011) Translating Women, Ottawa: University of Ottawa Press. (2012) 'Translating Women: From Recent Histories and Re-translations to "Queerying” Translation, and Metramorphosis', Quaderns: Revista de traducció 19: 127-139.

Gerhard, Jane (2000) 'Revisiting "The Myth of the Vaginal Orgasm”: The Female Orgasm in American Sexual Thought and Second Wave Feminism', Feminist Studies 26(2): $449-476$. 
Gillis, Stacy and Rebecca Munford (2007) 'Interview with Elaine Showalter', in Stacy Gillis, Gillian Howie and Rebecca Munford (eds) Third Wave Feminism: A Critical Exploration (Expanded 2nd edition), Basingstoke: Palgrave Macmillan, 292-297.

Gillis, Stacy, Gillian Howie and Rebecca Munford (eds) (2007) Third Wave Feminism: A Critical Exploration (Expanded 2nd edition), Basingstoke: Palgrave Macmillan.

Glover, David and Cora Kaplan (2000) Genders, London: Routledge.

Goodman, Lizbeth (1999) Literature and Gender, London: Routledge in association with The Open University.

Guild, Elizabeth (1992) 'Écriture féminine', in Elizabeth Wright (ed.) Feminism and Psychoanalysis: A Critical Dictionary, Oxford: Blackwell, 74-76.

Hawthorne, Melanie C. (2000) 'Introduction', in Melanie C. Hawthorne (ed.), Contingent Loves. Simone de Beauvoir and Sexuality, Richmond, VA: Virginia University Press, $1-12$.

He, Ping (2009) 'On Problems of Chinese Feminism', http://actuelmarx.u-paris10.fr/ m4heping.htm (last accessed on 10 April 2009).

Howie, Gillian (2007) 'Interview with Luce Irigarary', in Stacy Gillis, Gillian Howie and Rebecca Munford (eds), 283-291.

Jacka, Tamara (review) (2007) Sex and Sexuality in China edited by Elaine Jeffreys, in Intersections: Gender, History and Culture in the Asian Context, Issue 15 (May 2007), http://intersections.anu.edu.au/issuel5/jacka_review.htm (last accessed on 5 November 2011).

Jeffreys, Elaine (ed.) (2006) Sex and Sexuality in China, London and New York: Routledge.

Jones, Ann Rosalind (1981) 'Writing the Body: Toward an Understanding of l'Écriture Féminine,' in Elaine Showalter (ed.) The New Feminist Criticism: Essays on Women, Literature, and Theory, London: Virago, 361-377.

Khanna, Shivani (2007) 'Theater Review: “The Vagina Monologues”, The Online Gargoyle, 7 March 2007, www.uni.illinois.edu//gargoyle/2007/03/imagine_spendingtwohours. htm (last accessed on 8 June 2010).

Ko, Dorothy and Wang Zheng (2006) 'Introduction: Translating Feminisms in China', Gender and History 18(3): 463-472.

Krolokke, Charlotte (2005) 'Three Waves of Feminism', www.sagepub.com/upm-data/ 6236_Chapter_1_Krolokke_2nd_Rev_Final_Pdf.pdf (last accessed on 8 October 2011).

Larkosh, Christopher (1996) The Limits of the Translatable Foreign: Fictions of Translation, Migration and Sexuality in 20th Century Argentine Literature, unpublished $\mathrm{PhD}$ dissertation, University of California Berkeley.

Lefevere, André (1992) Translation, Rewriting, and the Manipulation of Literary Fame, London and New York: Routledge.

Li, Qiang 李强 (trans.) (2004) 第二性 [The Second Sex], Beijing: 西苑出版社 [Xiyuan Publishing House].

Liu, Lydia H., Rebecca E. Karl and Dorothy Ko (eds) (2013) The Birth of Chinese Feminism: Essential Texts in Transnational Theory, New York and Chichester: Columbia University Press.

Lung, Rachel (2003) 'Translating Sensitive Texts', Perspectives: Studies in Translatology 11(4): 240-253.

Maier, Carol (1998) 'Issues in the Practice of Translating Women's Fiction', Bulletin of Hispanic Studies 75: 95-108.

Massardier-Kenny, Françoise (1997) 'Towards a Redefinition of Feminist Translation Practice', The Translator 3(1): 55-69. 


\section{Introduction}

McMillan, Joanna (2006) Sex, Science and Morality in China, London and New York: Routledge.

Min, Dongchao (2005) 'Awakening Again: Travelling Feminism in China in the 1980s', Women's Studies Internaltional Forum 28: 274-288.

— (2007) 'Duibua (Dialogue) In-Between: A Process of Translating the Term "Feminism" in China', Interventions 9(1): 174-193.

Moi, Toril (ed.) (1985) Sexual/Textual Politics: Feminist Literary Theory, London and New York: Methuen.

Munday, Jeremy (2006) 'Translation Studies', Year's Work in Critical and Cultural Theory 14: 195-208.

Niranjana, Tejaswini (1998) 'Feminism and Translation in India: Contexts, Politics, Futures', Cultural Dynamic 10(2): 133-146.

Olson, Loreen N., Tina A. Coffelt, Eileen Berlin Ray, Jill Rudd, Renée Botta, George Ray and Jenifer E. Kopfman (2008) '“I'm All For Equal Rights, But Don't Call Me a Feminist": Identity Dilemmas in Young Adults' Discursive Representations of Being a Feminist', Women's Studies in Communication 31(1): 104-132.

Poovey, Mary (1988) 'Feminism and Deconstruction', Feminist Studies 14(1): 51-65.

Rampton, Martha (2008) 'The Three Waves of Feminism', Pacific, The Magazine of Pacific University, www.pacificu.edu/magazine_archives/2008/fall/echoes/feminism. cfm (last accessed on 8 October 2011).

Ruan, Fang-fu (2007) 'Sexuality in China Today', Journal of Sex Research, http:// findarticles.com/p/articles/mi_m2372/is_3_44/ai_n27371539/ (last accessed 5 November 2011).

Sang, Tze-Ian D. (2003) The Emerging Lesbian: Female Same-Sex Desire in Modern China, Chicago and London: The University of Chicago Press.

Sang, Zhuying 桑竹影 and Nan Shan 南珊 (trans.) (1986) 第二性一女人 [ The Second Sex-Women], Changsha: 湖南文艺出版社 [Hunan Literature and Art Publishing House].

Santaemilia, José (2011) 'Gender, Sex and Translation: Preface', in José Santaemilia and Luise von Flotow (eds) MonTI 3 Women and Translation: Geographies, Voices and Identities, 9-28.

- (2014) 'Sex and Translation: On Women, Men and Identities', Women's Studies International Forum 42: 104-110.

Schaffer, Kay and Song Xianlin (2007) 'Unruly Spaces: Gender, Women's Writing and Indigenous Feminism in China', Journal of Gender Studies 16(1): 17-30.

Sigley, Gary and Elaine Jeffreys (1999) 'Interview: On "Sex" and "Sexuality" in China: A Conversation with Pan Suiming', Bulletin of Concerned Scholars 31(1): 50-58.

Simon, Sherry (1996) Gender in Translation. Culture and Identity and the Politics of Transmission, London and New York: Routledge.

Snyder, R. Claire (2008) 'What is Third-Wave Feminism? A New Directions Essay', Signs 34(1): 175-196.

Spakowski, Nicola (2011) “"Gender” Trouble: Feminism in China under the Impact of Western Theory and the Spatialization of Identity', Positions: East Asia Cultures Critique 19(1): 31-54.

Spencer, Jane (2007) 'Afterword: Feminist Waves', in Stacy Gillis, Gillian Howie and Rebecca Munford (eds), Third Wave Feminism: A Critical Exploration (Expanded 2nd edition), Basingstoke: Palgrave Macmillan, 298-303.

Tao, Tiezhu 陶铁柱 (trans.) (1998) 第二性（全译本) [The Second Sex (complete translation)], Beijing: 中国书籍出版社 [China Books Publishing House]. 
Wallmach, Kim (2006) 'Feminist Translation Strategies: Different or Derived?', Journal of Literary Studies 22(1/2): 1-26.

Wang, Youqin 王友琴 and Qiu Xichun 邱希淳 et al. (trans.) (1988) 女人是什么 [ What is Woman?], Beijing: 中国文联出版公司 [China Federation of Literary and Art Circles Publishing Corporation].

Widerberg, Karin (1998) 'Translating Gender', NORA: Nordic Journal of Feminist and Gender Research 6(2): 133-138.

Xinran (2005) 'Sex in Chinese Culture', The Guardian, 6 May 2005, www.guardian. co.uk/world/2005/may/06/china.gender (last accessed on 3 September 2011).

_ (2008) 'In the New China, Sex can Still be the Stuff of Scandal', The Guardian, 16 February 2008, www.guardian.co.uk/commentisfree/2008/feb/16/china (last accessed on 3 September 2011).

$\mathrm{Xu}$, Feng (2009) 'Chinese Feminisms Encounter International Feminisms', International Feminist Journal of Politics 11(2): 196-215.

Yu, Rongjun 喻荣军 (trans.) (2003) 阴道独白 [The Vagina Monologues], http://bbs. sachina.pku.edu.cn/archiver/tid-3681.html (last accessed on 27 December 2006).

Zhong, Xueping (2006) "Who is a Feminist? Understanding the Ambivalence towards Shanghai Baby, 'Body Writing' and Feminism in Post-Women's Liberation China”, Gender and History 18(3): 635-660. 


\section{Feminist translation Practice, theory, and studies}

French feminism is one of the main schools of feminism in the world. Its English translation began in the 1970s, and produced some 'problematic effects'. Subsequently, a group of Canadian translators (such as Godard and LotbinièreHarwood) began to translate works of French Canadian feminists. They call themselves feminist translators 'not just because they translate feminist works (which is not new) but because they wish to imitate the original authors' innovative writing process as part of the translation process' (Wallmach 1998: 19-23). The emergence of Canadian feminist translation in the late 1970s is closely related to the political and cultural background, and must be understood within the wider context of translation itself in Canada, especially from the 1960s onwards. Canada, especially in the province of Quebec, has been and remains acutely conscious of the fact that the country is officially bi-lingual, and must at least in Quebec be seen to be so for obvious political reasons, as Francophone Quebecois had been agitating for secession from the Canadian Confederation. To appease such discontent as well as fear about the survival of French in an increasingly powerful Anglophone world both within and outside Canada, initially literary translation from French into English was carried out on a large scale (presumably to make Anglophone Canadians aware of the richness of Quebec's French literary culture and heritage), but today, translations from English into French can be said to be even greater in volume (Anonymous n.d.).

The Québécois feminist texts make 'extensive' use of linguistic wordplay, allowing the translators to use 'innovative' translation strategies (Wallmach 1998: 23), and Canadian feminist translation is characterised by a 'renewed sense of agency' in translation (Simon 1996: 29). A translation theory to specifically target feminist translation has been proposed (Wallmach 1998: 23). Feminist translation theory takes translation as a creative activity and regards translation as production rather than reproduction, because feminist translators exercise their agency and creativity in translation activities to serve feminist agendas. During the translation process, feminist translators revise and rewrite the source text according to 'feminist truths', aiming at 'imbu[ing] translation praxis with feminist consciousness' and 'making women visible and resident in language and society' (Lotbinière-Harwood in Flotow 1997a: 27). The strategies they use to deal with the language and cultural barriers, taboos as well as patriarchal bias 
in the source text not only show their resourcefulness but also exhibit their sense of humour (Flotow 1997a). Therefore, feminist translation can be described as re-creation, i.e. a productive writing called forth by the source text with an effect of entertainment in addition to its political and educational purpose, transmitting a serious message in a light and humorous manner. More importantly, feminist translators 'quite willingly acknowledge their interventionism' (Simon 1996: 29). They 'put its cards on the table from the very beginning', believing that neither writing nor translating is a neutral act. Hence, 'rewriting in the feminine' is also a self-conscious act for which no apologies are needed (LotbinièreHarwood in Flotow 1997a: 27). Overt interventions by feminist translators have inevitably attracted many criticisms, which have helped the formation of feminist translation studies. The following sections look into feminist approaches to translation, focusing on the major feminist translation strategies, which will serve as a point of reference in my examination of the strategies adopted by the Chinese translators in their translations of The Second Sex (TSS) and The Vagina Monologues (TVM); and review feminist translation studies both within and outside China to locate where we are in feminist translation studies and establish a niche for this study.

\subsection{Feminist approaches to translation}

Translators are traditionally expected or even assumed 'to keep their politics out of their work', whereas 'deliberate changes have often been made in rewritten texts, and frequently in the name of some ideology' (Flotow 1997a: 24). Nevertheless, the agency of feminist translators is not that of a 'free and unfettered writing subject', but a result of heightened awareness of the 'political and interpretative dimensions of their own project'. The 'enunciating position' of feminist translators 'gives content to the "difference" between original and translation, defines the parameters of the transfer process, and explains the mode of circulation of the translated text in its new environment' (Simon 1996: 29). The strategies that highlight feminist translators' active participation and efforts to produce an effect or change have been topical in translation studies. They were first summarised by Flotow (1991), later redefined by Massardier-Kenny (1997), outlined by Maier (1998), and then further clarified by Wallmach (2006), in addition to many other direct or indirect discussions of feminist translation strategies.

\subsubsection{Feminist translation strategies: Flotow's summary}

Flotow bases her discussion of feminist translation mainly on translation of experimental feminist writing, translation of texts that are unpalatable or politically unacceptable to politicised translators, and translation of women's works 'lost' in patriarchy (Flotow 1997a: 14-34). Widely known now are the three major strategies she summarised (and repeatedly mentioned in her works): supplementing, prefacing and footnoting, and hijacking (Flotow 1991: 74-80, also see Flotow 1997a and Simon 1996). 
(1) Supplementing, which compensates for the differences between languages and calls for intervention by the translator. For instance, English lacks the gender agreement that exists in French. When translating from French into English, it is necessary to compensate for the lack in English.

(2) Prefacing and footnoting, in which translators explain the intentions of the source text and outline their own translation strategies. These strategies foreground the translator's subjective input into the translation and have an educational function.

(3) Hijacking, a process by which a feminist translator applies 'corrective measures' to a text in hand, the intentions of which are not necessarily feminist, appropriating the text in order to construct feminist meaning.

These strategies are interconnected. There is some overlap between supplementing and hijacking. Both are a 'very visible and explicit form of interventionism, not necessarily demanded by the text itself, but rendered pertinent by the dissonance between the value and intention of the text in its time and contemporary perception' (Simon 1996: 35). In these three categories, prefacing and footnoting are among the many ways to supplement and compensate. They are often used by translators to explain anything they feel necessary for their translations. There are other ways translators can use to give their explanations, such as translator's notes, diaries, statements, and even theoretical writings or essays. These additional explanatory materials are usually called metatexts or paratexts of the translation (Genette 1997, Webster's New Millennium ${ }^{\mathrm{TM}}$ Dictionary of English 2006). They are all extra textual materials. In addition to summarising the three major strategies, Flotow (1997a) makes an inventory of the specific ways feminist translators have used to carry out feminist interventions, such as neologism, reclaiming some derogatory terms to develop new terms, feminisation, translating word play with other word play, over-translation, corrective measures, and self-censorship (Flotow 1997a: 18-34).

\subsubsection{Feminist translation strategies: Massardier-Kenny's redefinition}

In her essay 'Towards a Redefinition of Feminist Translation Practice', MassardierKenny reflects on and redefines 'feminist-identified translation'. She suggests using terms like 'woman-identified' and 'gender' rather than the term 'feminist', as she finds 'feminist' problematic for anyone wanting to interrogate the very category of gender (Massardier-Kenny 1997: 55, also see Martín 2005: 35). Her suggestion again reflects lack of consensus about the definition(s) on feminism, confusions in using 'feminist' as a modifier, and negative connotations attached to the label of feminism, pervasive both within and outside China (see Showalter 1977, Coward 1980, Moi 1986, Liu Siqian 1993, Sheng Ying 1994, Yan Chunde 1998, Qu Yajun 2003, Jiang Qinglin 2004, Li Youliang 2005, Qiao Yigang 2005). Massardier-Kenny queries the three main feminist strategies described by Flotow and argues that given the explanations of the strategies, it is not the strategies themselves that are feminist, assuming the notion of feminist itself is 
clear and non-controversial, but rather the use to which these strategies are put. Massardier-Kenny argues that the notion of supplementing is similar to the traditional translation strategy called 'compensation'. It becomes feminist when this strategy is used to emphasise the woman's point of view that is present in the source text and that the translator is determined to carry it over into the target text. Prefacing and footnoting are also strategies widely used for purposes other than feminist ones. Hijacking is the only one correctly described as feminist since it consists of deliberately 'feminizing the target text' (Massardier-Kenny 1997: 57). She categorises strategies in feminist translation practice into two general but useful dimensions (1997: 58-65):

(1) Author-centred strategies, which include recovery, commentary, and resistance, seeking to make the reader understand the source text. Recovery refers to the archaeological task of finding, publishing, and translating texts by women authors who were previously excluded from the canon. Commentary involves using the meta-discourse accompanying the translation to make explicit the importance of the feminine or of woman/women (either in terms of structural constraints or in terms of women's agency) in the text translated. Resistance means making the labour of translation visible through linguistic means that have a de-familiarisation effect and that work against easy fluency.

(2) Translator-centred strategies, which include commentary, use of parallel texts, and collaboration, seeking to bring the target text closer to the reader while preserving its difference. Commentary in this context serves a different purpose. It describes the motives of the translator and the way they affect the translated text in order to avoid reproducing a textual power structure which genders the translator as the male confessor of the text. The use of parallel texts refers to the use of the texts in the target language that are produced in a similar situation or that belong to the same genre as that of the source text. Collaboration involves working with one or more translators and/or with the author on a given text, rather than struggling alone to 'master' the text.

One advantage of this brief categorisation of strategies in feminist translation practice is that it can remove suspicion regarding the applicability of feminist translation strategies in non-Euro-American cultures. Massardier-Kenny (1997: 55 ) asserts that in spite of weaknesses of definition, 'feminist' translation practices present clear and significant gains rather than a restriction of the translator's activity. Therefore, in this book, 'feminist' is still used as there seems no better alternative that can embody the overt political implications in feminist translation practice.

\subsubsection{Feminist translation strategies: Maier's outline}

Maier's discussion of feminist translation strategies is closely related, and to some extent, responds to those of Flotow and Massardier-Kenny. Maier (1998: 98-102) 


\section{Feminist translation}

outlines four loosely-defined approaches and regards them not as a set of fixed categories but as elements in a continuum:

(1) No deliberate approach: This refers to a 'null' strategy or 'literal' translation, an approach of many translators both to translating women's fiction and to translation in general. This absence of an acknowledged approach can remove the question of what woman is from the translator, and then the translator would not need a definition of 'woman'.

(2) Feminist approach to woman: This resembles 'no deliberate approach' in two ways: (a) feminist translation is usually not concerned with a definition of 'woman' and feminist translators generally employ 'woman' without question while they have begun to recognise that 'feminism' and 'woman' are not universal terms; (b) the work of feminist translators also arises from a simultaneous affirmation and refusal, i.e. affirming women writers through a refusal to translate work written by men and often choosing to translate only explicitly feminist texts.

(3) Women-identified approach: This is related to a translator's identification or definition of her/his own work. Translators either identify themselves as women or work with authors identified as women.

(4) Women-interrogated approach: This means one works not as a womenidentified translator but as one who questions, even interrogates gender definitions. It involves an endeavour to work less from confidently-held definitions than from a will to participate in re-definitions, to counter the restrictions of a gender-based identity by questioning gender as the most effective or the most appropriate point of departure for a translator's practice.

In her paper, Maier uses the term 'strategy' and 'approach' interchangeably. Maier's first approach supports Massardier-Kenny's discussion of the nature of feminist translation strategies, i.e. it is the feminist use of the strategies that makes the strategies feminist (see 2.1.2). Her second and third strategies seem close to each other. The fourth one needs to incorporate a wide range of approaches. In discussing 'feminist' approach to 'woman', Maier mentions some feminist strategies discussed in Flotow's works (1991 and 1997a), such as footnotes and commentary, in which the translators explain their interventions, like inserting a translator's remarks (or person) in the text itself, or eliminating passages the translator considers non-feminist (Maier 1998: 99). As for 'womenidentified' approach, Maier states that she herself does not identify with it. In her own translation and reading experiences, she finds feminine and masculine language inseparable and the complex interaction between gender and other identities to be destabilising. She also finds that the scholarly editing (excisions and corrections made by men) in many translation projects compromises or even obscures the translation. Consequently, Maier has thought of working not as a women-identified translator, but as a woman-interrogated translator (Maier 1998: 101-102). 


\subsubsection{Feminist translation strategies: Wallmach's analysis}

Wallmach's discussion of feminist translation strategies makes particular reference to four French-Canadian feminist texts by Nicole Brossard and their feminist translations into English (two by Barbara Godard and two by Patricia Claxton). Wallmach analyses the strategies used in the feminist texts and their translations to examine if and how feminist translation differs from conventional translation. Wallmach believes that Canadian feminist translation is 'an approach to translation that has appropriated and adapted many of the techniques and theories that underlie the writing it translates' (Flotow in Wallmach 2006: 10). Drawing on Neubert's notion of translational creativity as derived creativity and the premise that some strategies could be considered to be more creative than others, Wallmach uses the categories of substitution, repetition, deletion, addition and permutation in analysing the nature and creativity of feminist translation strategies. Aiming to find out how innovative feminist translation strategies are, Wallmach defines these five categories as follows (2006: 14-18):

(1) Substitution, the most common translation strategy, which implies that the relevant source text is replaced by the relevant target textual item.

(2) Repetition, subdivided into borrowing and calque, which implies that the source text item is not substituted but repeated or transferred directly from the source text into the translation. Some or all of the formal features are reproduced.

(3) Deletion, a very frequent phenomenon unavoidable in actual translation practice, which means that the source text item is not rendered in the target text at all.

(4) Addition, the opposite process to deletion, which means that the target text turns out to contain linguistic, cultural or textual component features without apparent antecedent in the source text. Addition may also be due to conscious intentional interventions of the translator, and therefore could be considered to be the most important strategy in creating 'difference'.

(5) Permutation, or compensation, which means that the source text items are rendered in the target text (by means of some homologue or analogue, whether or not involving some addition or reduction), but its position within the target text does not reflect the relative position of its source text counterpart. Footnotes, parenthesis, italics and prefaces can be used in this case.

After defining these five categories, Wallmach finds it possible to fully describe feminist translation strategies using categories from Delabastita (1993) and Vinay and Darbelnet (1995), and argues that the types of strategies used in Godard's and Claxton's translations are not unique to feminist translation. That is to say, there is nothing new about feminist translation in terms of strategy. Perhaps, the most important point Wallmach makes is that what really matters is not whether feminist translation theory is substantiated by its practice, but whether there is enough supporting meta-discourse which claims the 'difference' of 
feminist translation theory as opposed to conventional translation theories. Wallmach detects in feminist translation an admirable demonstration of the workings of ideology in texts (2006: 23). Although Wallmach's findings are based on the analysis of only four translations, the conclusion echoes some of the criticisms mounted by Massardier-Kenny (1997), whose work has been outlined earlier (see 2.1.2). Massardier-Kenny has contended that hijacking is properly speaking the only 'feminist strategy' (Massardier-Kenny 1997: 57). Nevertheless, even highjacking is often used in non-feminist translation, if it is not used for feminising the target text but as radical interference with the text to make a point. Typical examples from outside the domain of feminist translation in the Chinese context include Yan Fu translating Evolution and Ethics (1898) and Lin Shu and Wei Yi translating Uncle Tom's Cabin (1901).

To take just one example, Yan Fu translates the title Evolution and Ethics (Huxley 1898) as '天演论' [On Evolution], leaving out the second half of the title. This is because he disagrees with Huxley's argument about social Darwinism. As a result, in translating the contents, he frequently moves away from the source text to give his own opinion based on some points in the source text. He foregrounds his own opinion in the form of an in-text note '复案' [Fu's Comments] at the end of each section. He even embeds his own view in the translation because his purpose is not simply to translate the text, nor even to introduce Western biology, but to take the source text as an instrument to give his own views about reforming and transforming Chinese society to rescue it from failure. Hence his translation is also to some extent creative writing (Yan Fu 1981: iii and 2002: 9). This is a striking example of a translator 'hijacking' the source text for a political purpose in the target context that has nothing to do with feminism. This is also a typical example of Lu Xun's grabbism, 'an active effort to choose and take from foreign cultures what is good and useful to the Chinese' (Zhang Longxi 1998: 154). Yan Fu's translation reveals that 'feminist' translation, however defined, adapts existing translation strategies rather than inventing new ones.

The strategies summarised by Flotow are the most frequently cited (and critiqued) ones, especially in China, while those by the other three complement Flotow's summary and help clarify the nature of the so-called feminist translation strategies. The four discussions reveal that what strategies translators choose and how innovative the translation strategies are, have much to do with the nature of the source text. Evidently, feminist translation strategies are not new inventions by feminist translators but a resourceful selection of general or conventional translation strategies to render the source text for feminist purposes. The so-called feminist translation strategies are conventional strategies that every translator may use or has used. Feminist translators appropriate some of the approaches for feminist intervention that foregrounds the 'aggressive' side of the approaches. Therefore, what is 'new' is the purpose of the translation rather than the approach. They are feminist in ideology rather than in technique. Many years later, Flotow confesses that the strategies she labeled as 'feminist' can be found in many other translation situations (2009a: 245). Feminist translation is a variant element in 
the translational system which shares some common features with other elements in the system but has its own characteristics because of different translation purposes. Therefore, feminist translation theory is more about an ideological meta-discourse than about actual translation techniques. In other words, it is the ideological standpoint that affects translation technique and practice. It is these discussions of feminist translation strategies that have intrigued and motivated me to examine the strategies used in the Chinese translations of TSS and TVM to see what strategies the Chinese translators use, whether the strategies are feminist or not, or how feminist or unfeminist (my term) their strategies are.

\subsection{Feminist translation studies: Within and outside China}

To review feminist translation studies, some questions must be answered: What is the standard for a translator, a researcher, or a work to be gauged as feminist? Where is the boundary of feminist translation studies and what should be included and excluded? Answers can vary, because not every person or text looks purely or explicitly feminist except the most prominent feminist figures or texts. Indeed, many are reluctant or even refuse to be labelled as feminist, even if their works reveal feminism or women's awareness. They may 'live feminist lives and promote feminist ideals but refuse to use the label of feminism' (Olson et al. 2008: $105)$ due to the 'spooky stereotypes about feminists and their freaky excesses' (Baumgardner and Richards 2000: 62).

Although unsatisfactory to many people, the debatable terminology 'feminist/ feminism' developed at a particular moment continues to be used; and what exactly constitutes feminism remains controversial. Varied definitions reflect different demands from different cultural, geographical and historical contexts. For example, Showalter, Coward, and Moi, rigidly or loosely, have all tried to define feminist by making a distinction between feminist, female, and feminine (Showalter 1977: 13, Coward 1980: 379, Moi 1986: 104-116). Coward even tries to differentiate the loosely called feminist novels into four categories but without giving each category a label (1980: 379). In spite of all these efforts, it still seems very difficult to make satisfactory and clear-cut distinctions between female, feminine, and feminist, although broadly 'feminist' can be regarded as a political position, and female and feminine as ways of being. It becomes even more complicated when the implications of feminism have been constantly changing and feminism has evolved into a third wave from the 1990s (Fixmer and Wood 2005, Snyder 2008: 176). Third-wavers have claimed to be less rigid and judgmental, and more inclusive and radically diverse than the secondwavers, 'embrac[ing] a multiplicity of identities, accept[ing] the messiness of lived contradiction, and eschew[ing] a unifying agenda'; as a result, it is hard to thematise the third-wave feminism (Snyder 2008: 176-180). For thirdwavers, feminism is 'a position open and available for everybody-regardless of gender' (Egeland 2004: 185), 'an ongoing project, [...] constantly being reinvented, [...] through determination and compromise' (Douglas 1995: 273), 
and hence 'individual to each feminist' (Snyder 2008: 177). Paying attention to gender issues and favouring social justice, the third-wave feminism seems to be generous and tolerant, embracing diverse approaches. It has been suggested to take those Chinese as feminists who are committed to and strive for 'sexual equality'. Many Chinese are actually feminists in this sense (Jiang Xinyan 2000: 157). ${ }^{1}$

As there have been various feminisms at different times and in different cultures, it is necessary to redefine the term 'feminism' at each use to suit the specific context. The inclusiveness of the third-wave feminism opens a way for reviewing feminist translation studies that appeared in the era of second-wave feminism. In this study, I adopt the third wavers' inclusive stance to review feminist translation studies, which in this book loosely include those directly related to feminism and those related to gender, sex and women, as well as those resulting from feminist influence. In other words, feminism-, women-, and gender-related research, and research exhibiting feminist, woman, and gender awareness are included. Due to the scope and the language pair being English-Chinese in this study, my discussion of existing feminist translation studies focuses on those in China. As for those outside China, I give a very brief review simply to show what has been studied to exhibit the contrast and relation with the studies in China. Only those works that are influential in feminist translation studies in China and important to this study are discussed, because, to some extent, it was these works that ignited and pushed feminist translation studies in China and thus have become an inextricable part of feminist translation studies in China.

\subsubsection{Feminist translation studies outside China}

Several rounds of careful search by early August 2014 from MLA International Bibliography (online resource) and other resources with such keywords as 'feminism, translation', 'woman, translation', and 'gender, translation' gave the following total numbers of journal articles, dissertations, book chapters, and books in four periods: 88 (from 2011 to 2014), 152 (from 2000 to 2010), 54 (from 1990 to 1999), and 22 (from 1981 to 1990). These numbers are by no means exhaustive. Perhaps due to the restriction of the keywords, some articles from such journals as TTR, The Translator, and Meta are not all included. Research written in non-English languages is not counted. But the numbers can give a rough picture of feminist translation studies outside China, showing the trend of the development. Feminist translation studies in the 1980s, 1990s, and the twenty-first century are reviewed below to delineate the emergence and development of feminist translation studies outside China. Translation of sexuality is a recent research subject derived from attention to gender issues in translation. Since translation of the female body and female sexuality is the focus in this project, studies of translating sexuality are reviewed separately, regardless of the time periods. 


\subsubsection{Feminist translation studies in the 1980s}

The discussion of anti-feminism in translation in 1981 (Bornstein 1981) might be the start of feminist translation studies outside China. Thereafter, discussions came one after another, concerning various topics, such as sexist translation in TSS (Simons 1983), ${ }^{2}$ cooperation between the translator and the author to achieve a feminist translation (Levine 1983, Diaz-Diocaretz 1985), the role of the translator's gender (Voldeng 1984, Room 1989), women in translation (Maier 1985, Hannay 1985), translating French feminism (Porter 1987), feminism in translation (Lippit 1988), genre and gender in translation (Krontiris 1988), gender in the representation of translation (Chamberlain 1988), translating sexist language (Bird 1988), and academic discourse in translating feminist theory (Banting 1989). During this period, much work on the nexus of gender, feminism and translation was done by Godard (1983, 1984, 1985 and 1989) and Mezei (1986, 1988a, 1988b and 1989), often based on their own translation practices. During this period, scholarly interest in feminism/women/gender and translation were also expressed in several special issues of journals, such as 'Women in Translation', Translation Review (1985) no. 17, 'La Traduction au féminin/Translating Women', Tessera (1989) no. 6, and 'Special Section on Feminist Translation of the New Testament', Journal of Feminist Studies in Religion (1989) no. 8(2): 25-85. This interest is still continuing and growing today, as will be seen in 2.2.1.3. The scholarship in this period is the basis of the two books respectively by Simon (1996) and Flotow (1997a), and prepared for the formation of feminist translation studies.

\subsubsection{Feminist translation studies in the 1990s}

The 1990s witnessed a proliferation of feminist translation studies from various perspectives, such as the feminism component to translation (Zwarg 1990), feminist biblical translation (Castelli 1990), the connections between feminism and translation in the context of French translation (Lotbinière-Harwood 1991), French feminist theory in translation (Freiwald 1991), the overlapping relational systems of gender and translation (Godard 1991), feminist translation strategies (Flotow 1991 and 1997a, Massardier-Kenney 1997, Maier 1998), more discussions on cooperation between the translator and author or among translators (Levine 1991), the feminist translator's delight in translation (Bassnett 1992), woman's role in translation and translation studies (Krontiris 1992, Morsberger 1993, Robinson 1995), politics of translating the Third World texts on women's writing (Spivak 1992), the political import and impact of translation within the domain of international feminism or feminisms (Penrod 1993), gender and race in translating slavery (Kadish and Massardier-Kenney 1994), contradictions in feminist translation (Arrojo 1994 and 1995), gender in/and literary translation (Cordero 1995, Maier and Massardier-Kenny 1996, Mandrell 1997, Chance 1998, Wahrman 1999), more discussions on genre and gender in translation (Breinburg 1996), sexist language and translation (Cameron 1998), feminist 
approaches to translation and translation studies (Flotow 1996a), translating women's fiction (Maier 1998), interconnections between translation and feminism in several areas (Wallmach 1998), the interface of Anglo-American translation studies and gender studies (Flotow 1999), and gender identity in the text/reader transaction (Henitiuk 1999) or in representation of gender in translation (Hartman 1999).

In this period, two seminal books were published: Gender in Translation (1996) and Translation and Gender (1997a) respectively by Simon and Flotow, two pioneers in the field of gender and translation. Both books have been very influential in feminist translation studies. Gender in Translation is the first full-length study of feminist issues in translation practice and theory, providing a comprehensive introduction to translation practice, theory, and history from a gender perspective. In her book, Simon establishes an interesting link between translation, gender, and cultural studies, foregrounding 'the encounter between gender and translation studies' and 'position translation within cultural studies' (Simon 1996: viii-ix). Her investigation of the role of gender in translation shows how translation studies can be enriched by a cultural studies framework.

Flotow is a figure who has worked steadily in this area since 1991 (see Flotow 1991, 1994, 1995a, 1995b, 1996a, 1996b, 1997a, 1997b, 1998, 1999, 2000a, 2000b, 2002, 2005, 2006, 2007, 2009a, 2011, and 2012). In her 1997 book, she gives a systematic discussion on feminist translation based on her research since 1991, from the emergence and development of feminist translation to specific feminist translation practices. Her book begins with a concise summary of how the women's movement in the late 1960s and early 1970s has 'problematized' language to expose that 'language is not only a tool for communication but also a manipulative tool' (Flotow 1997a: 8). Her thoughtful examination of gender and translation covers feminist influences on contemporary translation practices, theoretical developments and critical work on translation, gender as a cultural construct, and translation as a cultural transfer. She also discusses a plurality of perspectives and criticisms of feminist approaches to translation and translation studies, concluding that '[w] $\mathrm{w}$.re there is no controversy or discussion, there is often only silence' (Flotow 1997a: 88).

Simon's and Flotow's books complement each other, forming a full and clear account of the emergence, development and influence of feminist translation up to the time the books were published. They mark the formation of feminist translation theory, and through them, feminist translation theory has been known worldwide. Studies concerning feminism and gender are often both stimulating and controversial, as pointed out in the two books. Since their publication, these two books have drawn much attention both to themselves and to feminist translation practices and gender issues in translation, which have made them the two most important references in feminist translation studies, especially in China, where they have 'inspired similar feminist approaches to translation' (Sun Yifeng 2012: 43). In this decade, studies involving languages of non-Euro-American countries appeared, such as Japan (Kawachi 1998), India (Zide 1994, Niranjana 
1998), Pakistan (Abbas 1999), Mexico (Johnson 1991, Potter 1998), and Uruguay (Barker 1998). These show that feminist translation studies are spreading to more languages and cultures, a phenomenon rarely seen in the 1980s.

\subsubsection{Feminist translation studies in the twenty-first century}

Many of the works in the 1980s and 1990s were written by those who are feminist translators themselves, because they are 'well aware of the perspective that guides their work, and they often discuss their strategies in detail' (Maier 1998: 99), such as Godard (1989 and 1995), Lotbinière-Harwood (1991), Maier and Massardier-Kenny (1996), Massardier-Kenny (1997), Simon (1996), and Flotow (1997a). In the twenty-first century, many more researchers have joined in, leading to further development of feminist translation studies, with a broader scope than before. The first decade saw a dramatic increase in the number of works published. While some previous topics continue to fare well, such as the influence of gender identity or of feminism in translation (Hellerstein 2000, Hamerlain 2005), gender, feminism and religious translation (Newman 2001, Johns 2003, Spencer 2003, Clason 2006), genre and gender in translation (Grogan 2002), gender issues in translation (Andone 2002, Lee 2002, Leonardi 2007, Baxter 2010, Scarsi 2010, Schabert 2010), women's role in translation in history (Agorni 2005), feminism in translation (Flotow 2006), feminist translation strategies (Wallmach 2006, Eshelman 2007, Reimóndez 2009), and further discussion of Canadian feminist translation (Wheeler 2003, Capperdoni 2007), new perspectives are emerging, such as new possibilities for translation and gender (Littau 2000), feminism and orientalism in translation (Taylor 2000), similarities between feminist and post-colonial translators (Wallace 2002), the relations between translation, feminism, and Women's Studies (Gunew 2002), translation and the just society (Beetham 2002), gender, pedagogy, and translation (Maier 2003, Susam-Sarajeva 2005), translation, gender, and otherness (Bassnett 2005), gender and translation of scientific discourse (Sánchez 2007), feminist ethics of difference in translation (Shread 2007), the intersection between feminist sociolinguistic studies and feminist translation studies (Ergün 2010), and feminism and translation of fairy tales (Hennard Dutheil de la Rochère 2010). More discussions concern languages and cultures of non-Euro-American areas, such as China (Hu Ying 2000, Yue Ming-Bao 2000, Yoshihara 2004, Lai 2007, Chen Lijuan 2008, Lei 2009), Japan (Coutts 2002, Wakabayashi 2003, Kubota 2004, Smith 2005, Kitamura 2008), Korea (Hyun 2004), India (Taylor 2000, Selby 2002, Devika 2008, Sharma 2009), Africa (Hoffman 2007, Mwangi 2007 and 2009), Latin America (Stahl 2000, Bellessi 2002, Masiello 2002, Hedrick 2005), and the Middle East (Kahf 2000, Mehrez 2007, Kamal 2008).

New perspectives are partly reflected in Gender, Sex and Translation, another important book in gender-related translation studies, edited by José Santaemilia (2005c). This book indicates 'a breadth and richness of study [...] typical of Translation Studies' (Munday 2007). Feminist translation has been mostly practiced in genres like belles lettres, specialist feminist texts, and texts addressing 
women as readers (Wolf 2005: 24). Translations of these genres have been the major subject in early feminist translation studies. Santaemilia's collection breaks through this trend to include research on translations of more genres, such as translation of spoken language in film (Baumgarten 2005), and in the medical sphere (Weber, Singy and Guex 2005). It also includes research from perspectives not noticed before, such as gender issues in nationalist discourse (Ríos and Palacios 2005). More importantly, it contains research incorporating recent development in feminism (Martín 2005). As feminist translation emerged in the second wave of feminism, feminist concepts reflected in feminist translation and its studies, such as écriture feminine (Cixous 1975/1980), have sometimes seemed outdated in the era of the third wave of feminism. The theory of performativity gradually takes more currency in understanding the notion of gender (see Butler 1999). All these, together with the advent of queer theories, signify that there are many more areas to be explored in feminism/women/gender and translation, although how useful the 'queer' approach can be for translation and (feminist) translation studies is still uncertain and needs to be answered by time (see Flotow 2012: 133-134).

The beginning of the second decade of the twenty-first century witnessed a boom in feminist translation studies, with at least eighty-eight papers and books published in less than 4 years, more than half of what was published in the last decade. The research in recent years includes such topics as gender and oral (text) translation (Feral 2011, Palmary 2011, Rooyen 2011), female translator and translator-effect (Woods 2011, Jackson 2013), gender and translation (Breen 2011, Hosington 2012, Zoberman 2014), translating poetic texts by women or about women (Weber 2012, Wells 2013), gender in the biblical text translation (Parker 2013), women as translator, translation trainer, and translation scholars (Schaeffner 2013), translation and/or reception of feminism (Reimóndez 2013, Godayol 2014, Yusupova 2014). Studies concerning non-Euro-American languages and cultures have kept appearing, such as Japanese (Clements 2011), Afrikaans (Rooyen 2011), and Chinese (Li Bo 2013).

The boom was opened by two volumes on women and translation, viz. Translating Women edited by Flotow (2011), and MonTI 3 Women and Translation: Geographies, Voices and Identities edited by Santaemilia and Flotow (2011). In the same year, two edited volumes on gender and translation came out: Translating Gender edited by Federici in collaboration with Coppola, Cronin, and Oggero (2011), and Re-Engendering Translation: Transcultural Practice, Gender/Sexuality and the Politics of Alterity edited by Larkosh (2011). Each of the four volumes consists of fifteen, seventeen, sixteen, and six papers respectively, further exploring the intersection between feminism/women/gender and translation, meanwhile further unfolding this 'challenging area', which has 'fuzzy edges' but 'great critical and assertive potential' (Santaemilia 2011: 26). Among the four, the one edited by Federici focuses on translations between English and Italian. The other three, though still largely Euro-American-centred, include non-Euro-American languages and cultures, especially the one edited by Larkosh, which makes a priority of engaging a wide range of cultural and linguistic spaces, 
including African-American, Argentine, Haitian, Brazilian, Japanese, and Vietnamese languages and cultures. In 2013, another volume Bridging the Gap Between Theory and Practice in Translation and Gender Studies edited by Federici and Leonardi was published, which explores a European map of gender and translation. In the same year, a special issue of Gender and Language (7(1)) on translation was published, which reflects upon 'the intersection between gender, language and translation and the multiple crossroads that this conceptual triangle entails' (Castro 2013: 6). In 2014, the special issue of Women's Studies International Forum about 'Rethinking Women and Translation in the Third Millennium' came into being, in which seven papers discuss the position of women in the field of translation from different perspectives. This new issue promises to further nourish and stimulate work around sexual identity, gender, and translation (Flotow 2014: 56).

\subsubsection{Sexuality in translation studies}

Sexuality came to be an analytical category in translation studies recently, often related to censorship on sexuality (see Flotow 2000a and 2009b, Linder 2004, and Santaemilia 2008b). Studies on sexuality in translation started to appear from the mid-1990s (Davis 1995 and Larkosh 1996) and more appeared after 2000. Studies in the twenty-first century have covered several aspects, such as the English translation of sex in Beauvoir's works (Flotow 2000a), sexual imagery in Anglo-American translations of the Divine Comedy (Crisafulli 2001), sexual poetics and the politics of translation (Campbell 2003), sexual language and gender in translation (Santaemilia 2005a, 2005b, 2005c, 2006, 2008a, 2008b, 2014), translating English terms denoting a part of the body (Pârlog 2007), the roles of self-translation in the definition and development of sexual identity (Guldin 2007), the relationship between translation and sexuality, especially the forms of sexuality often considered to be beyond the limits of the normative (Larkosh 2007), and translating a description of an erotic body part and an erotics of translation (West 2010).

In existing research, homosexuality tends to become a new analytical category. Studies concerning gays in/and translation started to appear in the 1990s and is increasing in recent years, such as the treatment of homosexuality in translation (Boone 1993), a gay translator making gays visible in translating a gay text (Keenaghan 1998), translating gay texts and gay identity in translation (Harvey 1998, 2000, and 2003, Parker 2005), overt or covert translation of gay material (Mira 1999), and sexual identity in translating gay theatre (Kinloch 2007). Recent development shows a tendency of moving beyond homosexuality towards queer to be more inclusive and allow for new approaches, even if the study is about homosexuality (see Keenaghan 2011, Baer 2011, Spurline 2014a). In 2014, a special issue was published on 'The Gender and Queer Politics of Translation' in Comparative Literature Studies ((51)2), edited by Spurline, in which six papers address 'the gender and queer politics of translation studies across such diverse language fields as Spanish, French, Russian, Italian, English, 
German, and Arabic' (Spurline 2014b: 207). So far, only a couple of papers have been found on sexuality concerning Chinese language and culture, such as a paper about translations of erotic passages into Chinese written by the translators published in 2000 (Chen and Ma 2000), and a paper on translating gay literature in the Chinese context (Li Bo 2006). Authors of these two papers are all based in Hong Kong and both papers were published in English outside Mainland China. All the studies concerning homosexuality or queer found so far are limited to gays in/and translation. Very limited number of works on lesbian(ism) in/and translation have been found, such as Parker 1993 and Yu Zhongli 2011. In this book, Chapter Six is devoted to studying lesbianism in the Chinese translations of TSS and TVM and Chapter Seven to studying censorship of lesbianism in the Chinese translations of TSS and TVM.

\subsubsection{Feminist translation studies within China}

The data from MLA International Bibliography and the review above have depicted a clear trend of feminist translation studies outside China from its emergence to its expansion. The appearing of more research concerning non-Euro-American languages and cultures is likely to lead to a further expansion of feminist translation studies in the future. Research outside China, especially in the West, has great influence on and promotes feminist translation studies in China. Before the review of Chinese feminist translation studies, it is necessary to have a quick look at (general) translation studies in China, a context in which Chinese feminist translation studies has grown.

The term '译学' [translatology or translation studies] was already in use in the 1930s. Dong Qiusi, the first Chinese to declare translation a science, used the term in 1951 to propose the establishment of translation studies as a discipline. However, due to the social and political upheavals soon afterwards, translation studies could not developed until the early 1980s (Luo Xuanmin and Hong Lei 2004: 25-26, Sun Yifeng 2012: 36). Several rounds of careful search of the China National Knowledge Infrastructure (CNKI) database by 16 August 2014 with 'translation' as the keyword produced a result that paints a rough picture of translation studies in China. The CNKI record of journal articles on or relevant to translation started from 1980, although one paper of 1959 is also collected. In the decade from 1980 to 1989, the total number of journal articles is only 117. The number grew slowly each year from the 1990, and reaches 677 in total in the next decade from 1990 to 1999, during which China 'selectively embraced the discipline' (Munday 2007: 214). The number increases to 530 in the year 2000 alone, and since then it has grown steadily and exponentially. ${ }^{3}$ One important reason for the increase is 'the institutionalization of the Faculty Appraisal System in Chinese colleges, universities, and educational institutions', which requires the members of the teaching or research faculty to meet the standard of the number and quality of academic publications (Jun Tang 2009: 171). Another reason is the influence of Western theories. Before the mid-1990s, Chinese scholars had little access to Western academic literature, 
but since then, have had better access to it (Jun Tang 2009: 171), either through importation or through Chinese scholars going aboard for academic visits. The 'relatively well developed translation theory in the West', first linguistic school, and later cultural school, was embraced with great enthusiasm by Chinese translation scholars 'in search of a new and more vigorous conception of translation' (Sun Yifeng 2012: 38).

Graduate students have constituted another important contributing factor, as many graduate programmes in translation studies and translation and interpreting training have cropped up in recent years. In many universities, MA and PhD students are required to publish a couple of articles in order to obtain their degrees. This leads to MA and PhD students trying to publish their course essays or part of their dissertations before they graduate. Some get their dissertations published after graduation in the form of journal articles or books (usually in the case of PhD dissertations). A dissertation is often turned into one or several papers. Universities gradually discarded the publishing requirement for MA students due to the huge number of students and limited number of journals, but some have resumed it recently. In any case, publications during MA study still count for the students in winning awards during their study and when seeking a job. Therefore, many students try to publish a couple of articles before their graduation although they have to pay for the publications. Many universities still require $\mathrm{PhD}$ students to publish a certain number of papers in good journals before graduation. While the postgraduate programmes lead to an 'unprecedented disciplinary expansion', it is also noted that some postgraduate prospects opt for translation studies because they are 'over-awed by the demanding subjects of literature and linguistics', and that 'there is considerable ignorance on the part of some of the applicants for translation research'. This partly reflects 'the reality of the discipline, which is unfortunately associated with the lack of rigor' (Sun Yifeng 2012: 44). This postgraduate phenomenon in Chinese translation studies is epitomised by Chinese feminist translation studies discussed below.

Translation studies in China in the twentieth century was dominated by 'applied Translation Studies', mostly pertaining to translator training, and Chinese scholars mainly applied linguistic theories to translation issues (Hung 2005: ix, Jun Tang 2009: 171). In the 1990s, Chinese translation studies was even considered as being 'in a crisis and the prison-house of language' (Wang Ning and Sun Yifeng 2008: 11). All this partly explains in China the extreme popularity of Nida and his notions of dynamic, formal, and functional equivalences, and the frequent application of Newmarks' concepts of communicative translation and semantic translation. Since 2000, many more Western translation theories, including feminist translation theory, have come to China and provided new perspectives for Chinese translation studies. Although the main trend in contemporary China is linguistic, more and more Chinese scholars pay attention to cultural factors (Luo Xuanmin and Hong Lei 2004: 28). One instance is that Western feminist translation practice and theory have gradually drawn scholarly attention to feminist thinking on translation, gender issues in translation, women 
translators, and translation of feminist texts or texts about women and/or by women, especially those which reflect feminist or woman awareness. The current state of translation studies, reflected in Translation, Globalisation and Localisation: A Chinese Pespective edited by Wang Ning and Sun Yifeng (2008), gives such an impression that 'China seems to be discarding wholesale linguistic studies' (Munday 2010: 234).

From several rounds of careful search of CNKI from 2008 to 16 August 2014, with such keywords as ‘女性主义, 翻译’ [feminism, translation], ‘性别, 翻译’ [gender, translation], and ‘女性, 翻译’ [women, translation], supplemented by search from other sources like iLib (www.ilib.cn/), VIP (www.cqvip.com/), and the major journals that publish articles of translation studies, including 中国翻译 [Chinese Translators Journal], 中国科技翻译 [Chinese Science \& Technology Translators Journal], 上海翻译 [Shanghai Journal of Translators], 外语教学与研究 [Foreign Language Teaching and Research], and 外国语 [Journal of Foreign Languages], we see that there have been at least 674 journal articles, $229 \mathrm{MA}$ dissertations, and nine $\mathrm{PhD}$ dissertations in or related to feminist translation studies (see Tables 2.1 and 2.2). These figures may not be exhaustive, due to the reasons indicated before. The case of my students is an example in point. In 2008, four MA students of mine graduated with their dissertations on feminist translation. Two of their dissertations can be found in CNKI while so far the other two are not. Nevertheless, even if some studies are left out in some years and although the figures for 2014 (and maybe also some other years) are not final, the data collected can tell the story of the emergence and development of feminist translation studies in China.

Table 2.1 Number of dissertations on women/gender/feminism and translation (2004-2014)

\begin{tabular}{lllllllllllllll}
\hline rear & 2004 & 2005 & 2006 & 2007 & 2008 & 2009 & 2010 & 2011 & 2012 & 2013 & 2014 & Total \\
\hline MA Diss. & 4 & 7 & 28 & 21 & 19 & 27 & 25 & 29 & 30 & 33 & 6 & 229 \\
PhD Diss. & 1 & - & - & 1 & 1 & 1 & 4 & - & - & - & 1 & 9 \\
Total & 5 & 7 & 28 & 22 & 20 & 28 & 29 & 29 & 30 & 33 & 7 & 238 \\
\hline
\end{tabular}

Source: CNKI (16 August 2014).

Table 2.2 Number of journal articles on women/gender/feminism and translation (1996-2014)

\begin{tabular}{lllllllllll}
\hline Year & 1996 & 1998 & 1999 & 2000 & 2001 & 2002 & 2003 & 2004 & 2005 & Total \\
\hline No. & 2 & 2 & 2 & 2 & 3 & 5 & 6 & 12 & 21 & 55 \\
\hline Year & 2006 & 2007 & 2008 & 2009 & 2010 & 2011 & 2012 & 2013 & 2014 & Total \\
\hline $\begin{array}{l}\text { No. } \\
\text { Total }\end{array}$ & 36 & 57 & 78 & 68 & 83 & 67 & 76 & 104 & 50 & $\begin{array}{l}619 \\
674\end{array}$ \\
\hline
\end{tabular}

Source: CNKI and other sources (16 August 2014). 


\subsubsection{Emergence of feminist translation studies in the 1990s}

A 'late player in Translation Studies in its modern sense', China lagged behind the West in feminist translation studies for more than a decade. Feminist translation practices and studies were unknown in China in the 1980s when they appeared in Canada. In 1994, a translated article about Canadian translation tradition was published, in which feminist translation strategies and famous feminist translators in literary translation were briefly mentioned (see Luo Linquan and Mu Lei 1994: 88-89). This might be the first time that the term 'feminist translation' was known in China, which gradually drew scholarly attention. Two years later, a paper on schools of translation studies in the West included a short introduction to Canadian feminist translation theory and pointed out that the target of Canadian feminist translation was to raise the status of translators and stress the subjectivity of translators, which was enlightening to Chinese translation studies (Han Jiaming 1996: 49-50). In 1998, when discussing the dimensions of Western translation theory, Liao Qiyi briefly mentioned feminist thinking on women's language and translation in Canada. Xie Tianzhen (1999) noted the influence of Western feminism in translation studies in his book 译介学 [Medio-translatology], a coined term with a similar meaning to 'translation studies'.

In addition to such brief mentioning of Canadian feminist translation, there also appeared some discussions of feminism in/and translation and women translators. Being aware of non-sexist language in English as a result of the women's liberation movement in the West, Liang Maocheng (1996) proposed that non-sexist language should be used in Chinese-English translation so as to avoid sexist language, such as in the case of translating Chinese pronouns into English. Through comparing the English source and Chinese translations of The Complete Adventures of Sherlock Holmes, Eva Hung (also known as Kong Huiyi, a scholar based in Hong Kong) (1998) discussed the distortion of Western women's image in translated novels in the late Qing dynasty and analysed the cultural motives behind that distorted image. Such type of discussion based on examination of real translations was not commonly seen in Mainland China in the 1990s, when traditional translation studies still prevailed, which consisted of two major types of studies: “空泛的赞赏' [shallow admiration], like 'faithful' and 'fluent', or '集中讨论译文的错误' [focusing on mistranslations], such as those due to translators' incompetence (Wong 1999: 7). Fan Wenmei (1999) interpreted 'free women' in Doris Lessing's short stories and explained her translation of them. Mu Lei interviewed 'Lady Translation' Jin Sheng Hwa (a translator and scholar based in Hong Kong) to probe into the world of female translators, especially the experiences of female translators, to see how different they might be from those of male translators (Mu Lei 1999). This was her first interview with a female translator. The subsequent interviews with Eva Hung and Zhu Hong (a mainland scholar and feminist translator) took place in 2002 and 2003 respectively. Her interest in female translators was triggered when she found that the translation field was almost completely dominated by men. One 
illustration of this is that female translators account for only 7.5 per cent of the total number of translators included in 中国翻译家词典 [Dictionary of Chinese Translators] (Mu Lei et al. 2008: 169).

In China, due to historical, political, and social reasons, it was not until the twentieth century that women translators gradually appeared, most of them being women writers themselves (Mu Lei 1999). Mu Lei's interviews with women translators to some extent have become the start of a 'rediscovery' of Chinese women translators. After her three interviews, there appeared considerable interest in Chinese women translators, as well as translations by women translators, such as Zhu Hong, Eva Hung, and Eileen Chang (known as Zhang Ailing in China, a world famous Chinese writer). Although not numerous, the works in the 1990s constitute the rudiments of feminist translation studies in China. Many more works have appeared in the new century.

\subsubsection{Development of feminist translation studies in the twenty-first century}

At the beginning of the new century, Western feminist translation theory, together with post-structuralism and post-colonialism, still imposed a 'cultural shock' to Chinese scholars with traditional views of translation studies, who had been preoccupied with linguistic issues and literal versus free translation debates (Lin Kenan 2000: 59). In 2000, Liao Qiyi (2000) introduced the influence of feminist translation in his book 当代西方翻译理论探索 [An Exploration of Contemporary Western Translation Theory]. Thereafter, Western feminist translation practice and theory have gradually been introduced into China in various ways, and attracted growing interest that has led to the number of journal articles and MA dissertations in the field increasing each year (see Tables 2.1 and 2.2).

The journal articles and dissertations cover a variety of topics. Such topics as translator's (inter)subjectivity, translation strategies and effects, feminist re-writing and intervention, and fidelity and equivalence appear to be attractive, especially to MA students, taking about 45 per cent in MA dissertations (and 29 per cent in journal articles). Gender and women related issues seem appealing to both MA students and academics, taking about 33 per cent and 29 per cent respectively of the total, including one article on gender issues in interpreting. Feminism-related issues, including (the influence of) feminist translation in China, have also attracted much attention, constituting about 17 per cent of MA dissertations and 15 per cent of journal articles. Translation of the body and sexuality started to appear from 2008 , making up 0.8 per cent of MA dissertations and 1.8 per cent of journal articles. Some study feminist translation from other perspectives, including hermeneutics, adaptation theory, deconstructionism, polysystem theory, manipulation theory, functionalism, ideology, skopos theory, post-colonialism, travelling theory, and relevance theory, accounting for 10 per cent of MA dissertations and 2 per cent of journal articles. Critical studies of feminist translation theory, mostly summaries of, introductions to, and comments on feminist translation theory (e.g. significance, contributions, limitations, 
and its applicability or reception in the Chinese context), constitute 13 per cent and 41 per cent of MA dissertations and journal articles respectively. A couple of short reviews of Chinese feminist translation studies have appeared.

One notable tendency is that studies on real translations have been increasing, showing growing attention to doing research through examining translation practices rather than abstract discussion of translation, especially in MA dissertations. Case studies in MA dissertations make up 67 per cent of the total; while in journal articles, case studies take only 15 per cent, with some examples repeated in different papers. In the case studies, comparative studies of different translations or translations by female and male translators take 27 per cent and 9 per cent in MA dissertations and journal articles respectively. Most of the case studies focus on literary translation, with some translations being repeatedly discussed. The Chinese translations of the following works have been studied in two to as many as eighteen MA dissertations: The Color Purple (18), Jane Eyre (18), Wuthering Heights (12), The Old Man and the Sea (8), Vanity Fair (7), Gone with the Wind (6), The Rouge of the North (5), Pride and Prejudice (4), The Legend of Sleepy Hollow (4), An Ideal Husband (3), Emma (3), the Bible (3), The Scarlet Letter (2), The Rice-sprout Song (2), Gitanjali (2), Lolita (2), Lady Windermere's Fan (2), and To the Lighthouse (2). The English translations of the following works have been studied in two to six MA dissertations: 嬉雪 [A Frolic in the Snow] (6), 荒山之恋 [Love on a Barren Mountain] (5), 水汻传 [Outlaws of the Marsh] (5), 男人和女人, 女人和城市 [Men and Women, Women and the City] (4), 女人的“一样”和“不一样” [Are Women As Good As Men] (3), 并非梦幻 [Unlike a Dream] (3), 拣麦穗 [Gathering Wheat] (3), 金锁记 [The Golden Cangue] (3), and 海上花 [The Sing-song Girls of Shanghai] (2). The cases studied show strong interests in female translators and their translations. The following translators and their translations have been studied in three to as many as twenty-eight MA dissertations: Eileen Chang (28), Zhu Hong (11), Tao Jie (8), Yang Yi (7), Zhu Qingying (7), Pearl S. Buck (7), Yang Bi (7), Bing Xin (6), Eva Hung (4), Zhang Ling (4), and Gladys Yang (Gladys B. Tayler) (3), taking 41 per cent of the total. In the journal articles, there are a few recent very short discussions of female interpreters. In addition to literary texts, there have also appeared a few recent very brief discussions of other types or genres of texts, such as advertisements, trademarks, film subtitles, and songs.

One result of repeated discussions of the same translation or the same translator is that many papers and dissertations look similar, with some contents heavily repeated in some dissertations and articles. One reason is the considerable ignorance on the part of some MA students for translation research mentioned before. The case of one of my students illustrates this. When discussing a dissertation proposal with me, an MA student asked me: 'I find many students have done $\mathrm{X}$, can I also do it?' This question means the student had little idea of what to do and how to do it, even after taking the research methodology module. The existing dissertations (and journal articles) serve as a 'model' to many students. That is why repetition or similarity occurs in many dissertations and journal articles. Such phenomenon even occurs in PhD dissertations. In a 
recent article, Mu Lei and Zou Bing summarise several problems in doctorate dissertations in translation studies, based on their bibliometric analysis of nearly 700 doctorate dissertations in translation studies over the past 20 years, among which 624 dissertations are from the Mainland, forty-seven from Hong Kong, three from Macao, and twelve from Taiwan. The first problem on the list is repetition in research content and methodology (Mu Lei and Zou Bing 2014: $18)$.

It has been mentioned that postgraduate students make a considerable contribution to journal articles. The number (238) of MA and PhD dissertations means there are the same number of $\mathrm{MA}$ and $\mathrm{PhD}$ students working in feminist translation studies. Many students published more than one paper. This means most of the (674) journal articles were published by students. The titles, contents, and authors' names also reveal that a large proportion of the journal articles are adapted from the dissertations. This determines the quality of the research in feminist translation studies in China. Many journal articles are merely one to four pages, repeating or summarising similar things. Quite a number of students publish the same paper twice, a few even three times, mostly without any change, some with slightly changed titles. It seems the postgraduate phenomenon stands out here. Nevertheless, as Sun Yifeng (2012: 44-45) has noted, many graduate students in China pursue translation studies in earnest, and the discipline is flourishing with many translation scholars being trained.

The dates of publication of the journal articles and MA dissertations show the trajectory of the development of feminist translation studies in China, a journey from the landing of the notion of feminist translation in China to growing attention to it, with more and more researchers and postgraduate students being inspired to search, inspect, and reflect feminist translation in China. From 2000 onwards, there have been a few landmarks in the development of feminist translation studies in China. In 2001, the first chapter of Simon's Gender in Translation was translated into Chinese with the title of '翻译理论中的性别' [Gender in Translation Theory] and published in the book 语言与翻译的政治 [Language and the Politics of Translation] edited by Xu Baoqiang and Yuan Wei (2001: 309-357). This signals the arrival of the notion of Western feminist translation in China. Meanwhile, journal articles, introducing and discussing Western feminist translation practice and theory from different perspectives started to appear one after another, such as Wang Jianguo and Jia Jia 2001, Liu Yaru 2001, Liao Qiyi 2002, Yan Jianhua and Liu Jiangang 2002, and Ge Xiaoqin 2003. Postgraduate students became interested in gender issues in translation and started to work on them for their dissertations (see Table 2.2 and Mu Lei et al. 2008: 150). Because MA study usually takes 3 years and PhD study 3 or more years, dissertations in 2004 indicated in Table 2.2 should have been started from 2001 for MA students and before 2001 for $\mathrm{PhD}$ students

All these reached a small climax in 2004 when Flotow's Translation and Gender was reprinted in China in a local English edition. This and the work by Simon are two major references for those who do feminist translation studies and are hence among the most frequently cited works in China. In the same 
year, Chinese Translators Journal (no. 4), the only top-ranking academic journal in translation studies in China, published in the same volume four papers on feminist translation practice and theory respectively by Liu Junping, Jiang Xiaohua, Xu Lai, and Zhang Jinghua. This was the first time this journal published several papers on a single theme in one volume. Each paper contains an introduction to and a discussion of Flotow's Translation and Gender. These four papers together form a kind of detailed introduction, translation, and interpretation of Translation and Gender. This, to some extent, helps the spread of the gist of and the circulation of the book, since in China it is printed in English without Chinese translation. It is much easier for Chinese readers to read and understand what is introduced about the book in the Chinese papers than to read the English book. This volume also contains a report of the first national $\mathrm{PhD}$ forum in translation studies, which mentioned four papers discussing feminist translation practice and theory from different dimensions (Tian Yu and Ma Rao 2004: 55). Well before this point in 2004, the journal (no. 2) had published an article on 10 years of Canadian translation theory, in which Canadian feminist translation theory was introduced, especially the research by Simon and Flotow (Chen Lin 2004). In view of these, it seems reasonable to say that 2004 marks feminist translation studies settling down in China. From then on, steadily increasing interest in feminist translation studies can be seen, not just in journal articles and MA dissertations, but also in conferences. The report of the second national $\mathrm{PhD}$ forum in translation studies contains more research from gender/feminist perspective: eight papers, one-tenth of the total (Mu Lei 2006: 15-16, 18). In another national translation symposium in 2006, two among the eighteen literary translation papers are written from feminist perspective (Wang Hong 2007: 19).

Another important year is 2008 when discussions of translation of the body and sexuality, a new topic in China, appeared in three papers, all examining the Chinese translation of The Color Purple. Han Ziman compares two Chinese translations of The Color Purple and discusses how the translators dealt with sexual descriptions in the translations. He finds that the translators all delete descriptions of sexual acts and sexual organs. He contends that the deletions reflect a hidden ideology, i.e. the power of sexual taboo in literary translation, which constrains the translators (Han Ziman 2008: 84-85). Li Hongyu looks into four Chinese translations of The Color Purple to examine the relationship between translators' gender consciousness and translation practice. She finds that the female translators and the male translator have different understandings of the source text, especially the sexual descriptions, and adopt different strategies in translating the sexual descriptions. For example, two translators delete the description of the woman observing her sexual organ and one female translator (based in America) translates it without change. She attributes the deletion and complete translation of the sexual descriptions to the decisions of the publishers, rather than the translators' gender consciousness. She argues that translator's gender awareness in translation is constrained by the publisher and the cultural context (Li Hongyu 2008: 21-22, 25-28). Zeng Lixin's short paper compares 
two Chinese translations of The Color Purple through discussing two examples: one is about lesbian sexual pleasure and the other about a girl's appearance-her skin, hair and eyes. She finds that the female translator aptly expresses the woman's physical and psychological feeling, while the male translator only expresses the literal meaning, which reads very flat. She attributes the translation differences to the translators' gender identities, and concludes that a female translator can better understand and express woman's psychology and physiology and has a unique aesthetic orientation due to women's physical and psychological features as well as social expectations of women (Zeng Lixin 2008: 112). Thereafter, papers on the Chinese translation of The Color Purple have appeared each year, and similar examples and similar arguments are often seen in different papers.

Translation of the body and sexuality also appeared in a few MA dissertation and course essays. In her MA dissertation, Li Jiachang (2008) discusses translating the body in the Chinese context with a few examples from the two Mainland Chinese versions of TVM. With a brief analysis of the differences in translating female emotional and physical experiences and representing the feminine discourse of the source text, she points out three general influencing factors in translating the body in the Chinese context: the political factor, the cultural factor, and gender consciousness. It may be the third attempt in China in examining the Chinese translations of TVM from a feminist perspective. ${ }^{4}$ The first attempt took place in 2006 when an MA student of mine did a case study of the two Mainland translations to examine manipulation in feminist literary translation in her course essay for my 'Culture and Translation' module. Her essay briefly discusses translation of the female body and female sexuality, and thus may be the first student attempt at the topic in China, published or unpublished (see Huang Xiaoli 2006). The second attempt took place in 2007 when another MA student of mine explored in her course essay feminism in the Chinese translation by Yu Rongjun (see Wang Wen 2007). None of the present few discussions of Chinese translations of TVM include the Taiwan translation, which means that the Taiwan translation is unavailable or even unknown to most Mainland readers, although Ai Xiaoming had a copy for her students to use in producing their own translation of TVM. My analysis in this book is the first comprehensive study of the existing three Chinese translations and detailed examination of translating the female body and female sexuality in TVM in the Chinese context.

An interesting phenomenon in the above studies of translating the body and sexuality is the identities of the authors. All of them are MA students, except one PhD student and one postdoctoral fellow. All of them are female students, with only the one postdoctoral fellow being male. Their identities largely reflect those of the authors of the journal articles and MA dissertations in feminist translation studies. This also shows that feminist translation theory seems especially appealing to MA students, who are usually young and easily attracted by exciting subjects. The number of MA dissertations on the whole shows an increasing interest in feminism/women/gender and translation. 
However, the limited number of $\mathrm{PhD}$ theses on the subject so far implies that students have faced a kind of block in doing the research. It seems hard for the students to dig deeper into the subject, which might have prevented more students from continuing to work in the same direction. Another reason could be 'resistance' from some male examiners. Mu Lei has observed from the experiences of her own students that a dissertation on gender and translation received very good comments and a good mark from a female professor but a very low mark from a male professor who disagreed with the arguments of the student, while this dramatic difference in marking seldom happens in dissertations on other topics. Moreover, these students had to face more challenging questions in their oral examinations (Mu Lei et al. 2008: 151). The gender identity of the examiner that seems to have played a role in Mu Lei's story may be incidental, but an examiner's ideology does seem to affect his/her judgement in such occasions if he/she forgets that the student's research should also be given proper respect, whether he/she agrees or not. Anyhow, the story seems to have had a negative impact. A PhD student from Lingnan University, whom I met at the First International CTIS Postgraduate Conference 'Translation Frames: Gateways and Gatekeeping' held in Manchester in 2008, said that due to such incidents, many students would not choose to work on the subject for their PhD projects. This to some extent also shows that the research level has yet to be raised in feminist translation studies.

The MA dissertations show another phenomenon that the research interests of MA students often rely on the interests of their supervisors and the modules available in their first year. Take $\mathrm{Mu}$ Lei as an example. She seems to have exerted great influence on her students with her research interest in gender issues, although her major efforts are placed on translation teaching and she herself has not worked much on gender and translation. Many of her MA students have worked on gender-related issues for their MA dissertations: one in 2008, one in 2007, six in 2006, two in 2005 and one in 2004. Some have continued the research after their graduation (Mu Lei et al. 2008: 151-152). Their research can be found not only in the journal articles, but also in the book Gender Perspective in Translation Studies (Mu Lei et al. 2008), a collection of MA dissertations of her students. Their research composes a salient part of the upsurge of feminist translation studies in China. My students are another case in point. My teaching of translation theories has included feminist translation theory since 2006. Four students of the 2006 cohort chose to work on feminist translation or translation of feminist/female writing for their dissertations after I delivered the course. Among the students of 2005 whom I did not teach, no students worked on this or other issues that I covered in my teaching. Every year since 2006, quite a few of my students worked on translation from feminist/ gender perspective in their coursework or dissertations.

To sum up, the growing number and subjects of journal articles and MA dissertations since the last decade embody growing interest, increased topics, and more perspectives in feminist translation studies in China. Over half of the dissertations involving case studies indicate a shift in translation studies in China, 


\section{Feminist translation}

where traditional translation research pays much attention to abstract meditations or reflections on translation standard, criteria, and effect. However, the fact that the number of case studies in journal articles occupies only a small proportion in the total means that there is still insufficient examination of translation practices. The subjects and cases show the beginning of interest in women translators and translations by women translators, which have long been neglected in translation studies in China. Most of the translations for case study are by women translators or comparisons of translations by female translator(s) with those by male translator(s). This is another shift in translation studies in China. Interest in female translators and translations of women's writing indicates increased gender awareness of researchers, an indirect result from feminist translation studies. The emerging studies in translating the body and sexuality, although limited and largely fragmentary, show a breakthrough in studying taboo topics in China. This is an important progress as well as an expression of the influence of feminism. On the whole, feminist translation studies in China is still at a low level and at an early stage, with many works consisting of simple summaries and repetitions or short and shallow discussions. Most of the journals publishing the articles are low ranking, reflecting the low level of the research and the peripheral position of feminist translation studies in China. Nonetheless, the growing interest to some extent implies that feminist translation studies as an emerging branch in translation studies is gradually gaining momentum.

Although feminist translation studies in China came over a decade later and have not produced as much sound research, the existing research shows a similar trajectory of the development of feminist translation studies within and outside China. The existing feminist translation studies within and outside China from whatever perspective or stance reveal the major feature of feminist work-dis-unity and diversity. More importantly, Chinese feminist translation studies reflect growing interest in feminism in/and translation and geographical expansion in feminist translation studies, though it is still true that 'feminist work is largely produced by Anglophones or in response to translations to English' (Flotow 1998: 8). Feminist translation practices discovered in examining translations from a feminist perspective in other languages and cultures (such as China) imply that feminist translation as a practice is not a new invention of Canadian feminist translators, but has existed in other languages and cultures, where translators may not necessarily know the term or practice of 'feminist translation'. My analysis in Chapters Four to Six will illustrate this. Perhaps, the foremost contribution the radical Canadian feminist translation approaches have made to translation studies is that it has aroused and is still arousing feminist awareness of researchers, especially from outside the Euro-American context, that stimulates them to study translations from feminist perspective and to discover feminist translation practices or feminist translators in their own cultures. This research is one such attempt. 


\section{Notes}

1 Here 'sexual equality' should be understood as gender equality, according to the context.

2 Criticisms of the first English translation started in the 1980s; more criticisms came later, which will be discussed in Chapter Three.

3 The numbers given here are not necessarily exhaustive, nor precise. I searched several times to update them over the years, and each time I got different numbers. I am also aware that some papers on translation are not included, which I have also found in searching papers and dissertations in feminist translation studies. As the numbers are intended to show a rough picture of Chinese translation studies only, whether the numbers are precise or not does not affect the analysis.

4 In 2008, an MA student under my supervision worked out her dissertation on the two Mainland Chinese translations of TVM from the perspective of drama translation (Yuan Xidi 2008).

\section{Bibliography}

Abbas, Nuzhat (1999) 'Conversing to/with Shame: Translation and Gender in the Urdu Ghazal', Annual of Urdu Studies 14: 135-149.

Agorni, Mirella (2005) 'A Marginal(ized) Perspective on Translation History: Women and Translation in the Eighteenth Century', Meta L(3): 817-830.

Andone, Oana-Helena (2002) 'Gender Issues in Translation', Perspectives: Studies in Translatology 10(2): 135-150.

Anonymous (n.d.) 'Translation Studies', www.compcanlit.ca/about_translation.html (last accessed on 21 October 2011).

Arrojo, Rosemary (1994) 'Fidelity and the Gendered Translation', TTR 8(2): 147-164.

_ (1995) 'Feminist, "Orgasmic" Theories of Translation and Their Contradictions', Tradterm 2: 67-75.

Baer, Brian James (2011) 'Translating Queer Texts in Soviet Russia', Translation Studies 4(1): 21-40.

Banting, Pamela (1989) 'S(m)other Tongue? Feminism, Academic Discourse, Translation', Tessera 6: 81-91.

Barker, Patricia (1998) 'Looking Through the Barriers: Issues of Gender and Identity in Translating Mario Benedetti', Translation Review 56: 59-63.

Bassnett, Susan (1992) 'Writing in No Man's Land: Questions of Gender and Translation', Jlha do Desterro: A Journal of Language and Literature 28(2): 63-73.

- (2005) 'Translation, Gender and Otherness'. Perspectives: Studies in Translatology 13(2): 83-90.

Baumgardner, Jennifer and Amy Richards (2000) Manifesta: Young Women, Feminism, and the Future, New York: Farrar, Straus, and Giroux.

Baumgarten, Nicole (2005) 'On the Women's Service?: Gender-conscious Languages in Dubbed James Bond Movies', in José Santaemilia (ed.) Gender, Sex and Translation: The Manipulation of Identities, Manchester, UK and Northampton, USA: St Jerome Publishing, 53-70.

Baxter, Robert Neal (2010) 'Approaching Androcentrism in Galician Translation: Trends and Patterns', Galicia 21(1): 3-25.

Beetham, Margaret (2002) 'Speaking Together; Heteroglossia, Translation and the (Im)possibility of the Just Society', Women's Studies International Forum 25(2): 175184. 
Bellessi, Diana (2002) 'Gender and Translation', in Daniel Balderston and Marcy Schwartz (eds) Voice-overs: Translation and Latin American Literature, Albany, NY: State University of New York Press, 26-29.

Bird, Phyllis A. (1988) 'Translating Sexist Language as a Theoretical and Cultural Problem', Union Seminary Quarterly Review 42(1/2): 89-95.

Bogic, Anna (2011) 'Why Philosophy Went Missing: Understanding the English Version of Simone de Beauvoir's Le deuxième sexe', in Luise von Flotow (ed.) Translating Women, Ottawa: University of Ottawa Press, 151-167.

Boone, Joseph A. (1993) 'Framing the Phallus in the Arabian Nights: Pansexuality, Pederasty, Pasolini', in Valerie Wayne, Cornelia Moore, and Wimal Dissanayake (eds) Translations/Transformations: Gender and Culture in Film and Literature East and West: Selected Conference Papers, Honolulu, HI: University of Hawaii Press, 23-33.

Bornstein, Diane (1981) 'Anti-feminism in Thomas Hoccleve's Translation of Christine de Pizan's Epistre au dieu d'amours', English Language Notes 19(1): 7-14.

Breen, Margaret Sönser (2011) 'Gender and Translation: Writing as Resistance in Primo Levi's Se questo è un nomo', The European Legacy: Toward New Paradigms 16(2): 147-165.

Breinburg, Petronella (1996) 'Surinam Women Writers and Issues of Translation', in Joan Anim-Addo (ed.) Framing the Word: Gender and Genre in Caribbean Women's Writing, London: Whiting and Birch, 185-193.

Butler, Judith (1999) Gender Trouble: Feminism and the Subversion of Identity, New York and London: Routledge.

Cameron, Deborah (1998) 'Lost in Translation: Non-Sexist Language', in Deborah Cameron (ed.) The Feminist Critique of Language: A Reader, London: Routledge, $155-163$.

Campbell, Emma (2003) 'Sexual Poetics and the Politics of Translation in the Tale of Griselda', Comparative Literature 55(3): 191-216.

Capperdoni, Alessandra (2007) 'Acts of Passage: Women Writing Translation in Canada', TTR 20(1): 245-279.

Castelli, Elizabeth A. (1990) 'Les Belles Infidèles/Fidelity or Feminism? The Meanings of Feminist Biblical Translation', Journal of Feminist Studies in Religion 6(2):25-39.

Castro, Olga (2013) 'Introduction: Gender, Language and Translation at the Crossroads of Disciplines', Gender and Language 7(1): 5-12.

Chamberlain, Lori (1988) 'Gender and the Metaphorics in Translation', Signs 13(3): $454-472$.

Chance, Jane (1998) 'Gender Subversion and Linguistic Castration in Fifteenth-century English Translations of Christine de Pizan', in Anna Roberts (ed.) Violence against Women in Medieval Texts, Gainesville, FL: UP of Florida, 161-194.

Chen, Chapman 曾焯文 and Audrey Ma 马怡乐 (2000) “《近亲恋日记》的情色翻译” [Translations of Erotic Passages in Incest: A Journal of Love], 翻译学报 [Journal of Translation Studies] 4: 95-110.

Chen, Lijuan (2008) 'A Chinese Woman in Translation: A Feminist Rereading of Hong Ying's Ji'er de nü'er in English Translation', Translation Review 75: 27-36.

Chen, Lin 陈琳 (2004) ‘近十年加拿大翻译理论研究评介’ [Canadian Translation Theory and Research in the Recent Ten Years], 中国翻译 [Chinese Translators Journal] 25(2): 68-71.

Cixous, Hélène (1975/1980) 'The Laugh of the Medusa', in Elaine Marks and Isabelle de Courtivron (eds) New French Feminisms, Amherst: The University of Massachusetts, $245-264$. 
Clason, Marmy A. (2006) 'Feminism, Generic 'He', and the TNIV Bible Translation Debate'. Critical Discourse Studies 3(1): 23-35.

Clements, Rebekah (2011) 'Suematsu Kenchō and the first English translation of Genji Monogatari: Translation, Tactics, and the "Women's Question", Japan Forum 23(1): 25-47.

Comparative Literature Studies (2014) 'The Gender and Queer Politics of Translation', special issue, $5 \mathrm{l}(2)$.

Cordero, Anne (1995) 'Gender Terminology in Simone de Beauvoir and her Translators', Platte Valley Review 23(2): 51-61.

Coutts, Angela (2002) 'The Gendering of Japanese Literature: The Influence of Englishlanguage Translation on Concepts of Canon in the West', Japan Forum 14(1): 103-125. Coward, Ros (1980) “"This Novel Changes Lives”: Are Women's Novels Feminist Novels? A Response to Rebecca O'Rourke's Article "Summer Reading”, in Maggie Humm (ed.) Feminisms: A Reader, London and New York: Harvest Wheatsheaf, 377-380.

Crisafulli, Edoardo (2001) 'Dante's "Shameless Whore": Sexual Imagery in AngloAmerican Translations of the Comedy', TTR 14(1): 11-38.

Davis, Kathleen (1995) 'The Sexual Poetics of Translating "Desire in the Desert" in the Tenth Century', Studies in the Humanities 22(1/2): 86-99.

Delabastita, Dirk (1993) There's a Double Tougue: An Investigation into the Translation of Shakespeare's Wordplay, with Special Reference to Hamlet, Amsterdam: Rodopi.

Devika, J. (2008) 'Being "In-translation" in a Post-colony: Translating Feminism in Kerala State, India', Translation Studies 1(2): 182-196.

Diaz-Diocaretz, Myriam (1985) Translating Poetic Discourse: Questions on Feminist Strategies in Adrienne Rich, Amsterdam and Philadelphia: John Benjamins.

Douglas, Susan (1995) Where the Girls Are: Growing up Female with the Mass Media, New York: Random House.

Egeland, Cathrine (2004) 'Contentions: What's Feminist in Feminist Theory?', European Journal of Women's Studies 11(2): 177-188.

Ergün, Emek (2010) 'Bridging Across Feminist Translation and Sociolinguistics', Language and Linguistics Compass 4(5): 307-318.

Eshelman, David J. (2007) 'Feminist Translation as Interpretation'. Translation Review 74(1): 16-27.

Fan, Wenmei 范文美 (1999) ‘自由女性、互文关系和翻译’ [Free Women, Intertexuality and Translation], 中国比较文学 [Comparative Literature in China] 2: 110-121.

Federici, Eleonora (ed.) (in collaboration with Manuela Coppola, Michael Cronin and Renata Oggero) (2011) Translating Gender, Bern: Peter Lang.

Federici, Eleonora and Vabessa Leonardi (eds) (2013) Bridging the Gap Between Theory and Practice in Translation and Gender Studies, Newcastle: Cambridge Scholar Publishing House.

Feral, Anne-Lise (2011) 'Gender in Audiovisual Translation: Naturalizing Feminine Voices in the French Sex and the City', European Journal of Women's Studies 18(4): 391-407.

Fixmer, Natalie and Julia T. Wood (2005) 'The Personal is Still Political: Embodied Politics in Third Wave Feminism', Women's Studies in Communication 28(2): 235257.

Flotow, Luise von (1991) 'Feminist Translation: Contexts, Practices, Theories', TTR 4(2): 69-84.

_ (1994) 'Québec's “Écriture au féminin” and Translation Politicized', in F. Eguíloz, R. Merino (eds) Transvases Culturales: Literatura, Cine, Traduccion, Vitoria, Spain: Facultad de Filologia, Universida del Paris Vasco, 219-229. 
(1995a) 'Appendix: Beginnings of a European Project: Feminism and Translation Studies', TTR 8(1): 271-277.

_ (1995b) 'Translating Women of the Eighties: Eroticism, Anger, Ethnicity', in Sherry

Simon (ed.) Culture in Transit: Translating the Literature of Quebec, Montreal: Véhicule Press, 31-46.

_ (1996a) 'Translation Praxis, Criticism and Theory "au feminin"', Etudes Canadiennes/ Canadian Studies: Revue Interdisciplinaire des Etudes Canadiennes en France 22(41): 181-194.

— (1996b) 'Legacies of Quebec's “Écriture au féminin”: Bilingual Transformances,

Translation Politicized, Subaltern Versions of the Text of the Street', Journal of Canadian Studies, Spring Issue, 89-109.

_ (1997a) Translation and Gender: Translating in the 'Era of Feminism', Manchester: St Jerome.

_ (1997b) 'Mutual Pun-ishment? Translating Radical Feminist Wordplay: Mary Daly's “Gyn/Ecology” in German', in Dirk Delabastita (ed.) Traductio: Essays on Punning and Translation, Manchester: St Jerome and Namur: Presses Universitaires de Namur, $45-46$.

_ (1998) 'Dis-unity and Diversity: Feminist Approaches to Translation Studies', in Lynne Bowker, Michael Cronin, Dorothy Kenny and Jennifer Pearson (eds) Unity in Diversity? Current Trends in Translation Studies, Manchester: St Jerome Publishing, 3-13.

- (1999) 'Genders and the Translated Text: Developments in "Transformance", Textus 12(2): 275-288.

_ (2000a) 'Translation Effects: How Beauvoir Talks About Sex in English', in Melanie

C. Hawthorne (ed.) Contingent Loves. Simone de Beauvoir and Sexuality, Richmond, VA: Virginia University Press, 13-33.

— (2000b) 'Women, Bibles, Ideologies', TTR 13(1): 9-20.

- (2002) 'Gender in Translation: The Issues Go On', http://orees.concordia.ca/ numero2/essai/Von\%20Flotow.html (last accessed on 10 October 2007).

- (2005) 'Tracing the Context of Translation: The Example of Gender', in José

Santaemilia (ed.) Gender, Sex and Translation: The Manipulation of Identities, Manchester: St Jerome Publishing, 39-51.

— (2006) 'Feminism in Translation: The Canadian Factor', Quaderns. Revista de traducció 13: 11-20.

- (2007) 'Gender and Translation', in Piotr Kuhiwczak and Karin Littau (eds) A

Companion to Translation Studies, Clevedon, UK: Multilingual Matters, 92-105.

_ (2009a) 'Contested Gender in Translation: Intersectionality and Metramorphics', Palimpsestes 22: 245-255, 270.

— (2009b) 'Gender and Sexuality', in Mona Baker and Gabriela Saldanha (eds) Rou-

tlege Encyclopedia of Translation Studies (2nd edition), London: Routledge, 122-126.

_ (ed.) (2011) Translating Women, Ottawa: University of Ottawa Press.

- (2012) 'Translating Women: From Recent Histories and Re-translations to "Queerying” Translation, and Metramorphosis', Quaterns: Revista de traducció 19: 127-139. — (2014) 'Prologue', Women's Studies International Forum 42: 56.

Freiwald, Bina (1991) 'The Problem of Trans-lation: Reading French Feminisms', TTR 4(2): 55-68.

Gender and Language (2013), special issue, 7(1).

Genette, Gérard (1997) Paratexts: Thresholds of Interpretation, Cambridge: Cambridge

University Press, 1-2. 
Ge, Xiaoqin 葛校琴 (2003) ‘女性主义翻译之本质’ [The Essence of Feminist Translation], 外语研究 [Foreign Languages Research] 6: 35-38.

Godard, Barbara (1983) 'Translator's Preface', These Our Mothers, Toronto: Coach House Press; translation of Brossard (1977).

_ (1984) 'Translating and Sexual Differences', Resources for Feminist Research 13(3): $13-16$.

_ (1985) 'The Translator as She: The Relationship Between Writer and Translator', in Ann Dybikowski, Victoria Freeman, Daphne Marlatt, Barbara Pulling, and Betsy Warland (eds) In the Feminine: Women and Words/Les femmes et les mots, Edmonton: Longspoon Press, 193-198.

_ (1989) 'Theorizing Feminist Discourse/Translation', Tessera 6: 42-53.

— (1991) 'Translating (with) the Speculum', TTR 4(2): 85-121.

- (1995) 'A Translator's Journal', in Sherry Simon (ed.) Culture in Transit: Translating the Literature of Quebec, Montreal: Véhicule Press, 69-82.

Godayol, Pilar (2014) 'Feminism and Translation in the 1960s: The Reception in Catalunya of Betty Friedan's The Feminine Mystique', Translation Studies 7(3): 267283.

Grogan, Claire (2002) 'Crossing Genre, Gender and Race in Elizabeth Hamilton's Translation of the Letters of a Hindoo Rajah', Studies in the Novel 34(1): 21-42.

Guldin, Rainer (2007) " "I Believe that my Two Tongues Love Each Other cela ne m'étonnerait pas": Self-translation and the Construction of Sexual Identity', TTR 20(1): $193-214$.

Gunew, Sneja (2002) 'Feminist Cultural Literacy: Translating Difference, Cannibal Options', in Robyn Wiegman (ed.) Women's Studies on its Own, Durham, NC: Duke University Press, 47-65.

Hamerlain, Souad (2005) 'Translation as a Transmitter of Feminist Ideology', Annales du Partrimoine 3: 55-58.

Han, Jiaming 韩加明 (1996) ““翻译研究”学派的发展” [The Development of 'Translation Studies’ School], 中国翻译 [Chinese Translators Journal] 5: 48-50.

Han, Ziman 韩子满 (2008) ‘翻译与性禁忌——以The Color Purple的汉译本为例' [Translation and Sex Taboo-A Case Study of the Two Chinese Translations of The Color Purple], 解放军外国语学院学报 [Journal of PLA University of Foreign Languages] 31(3): 80-86.

Hannay, Margaret Patterson (ed.) (1985) Silent but for the Word: Tudor Women as Patrons, Translators, and Writers of Religious Works, Kent, OH: Kent State University Press.

Hartman, Kabi (1999) 'Ideology, Identification and the Construction of the Feminine: Le journal de Marie Bashkirtseff', The Translator 5(1): 61-82.

Harvey, Keith (1998) 'Translating Camp Talk: Gay Identities and Cultural Transfer', The Translator 4(2): 295-320.

- (2000) 'Gay Community, Gay Identity and the Translated Text', TTR 13(1): $137-165$.

(2003) Intercultural Movements: 'American Gay' in French Translation, Manchester: St Jerome.

Hedrick, Tace (2005) “"Mãe é para isso": Gender, Writing and English-language Translation in Clarice Lispector', Luso-Brazilian Review 41(2): 56-83.

Hellerstein, Kathryn (2000) 'Translating as a Feminist: Reconceiving Anna Margolin', Prooftexts: A Journal of Jewish Literary History 20: 191-207.

Henitiuk, Valerie (1999) 'Translating Woman: Reading the Female Through the Male', Meta XLIV(3): 369-484. 
Hennard Dutheil de la Rochère, Martine (2010) “ "But marriage itself is no party": Angela Carter's Translation of Charles Perrault's "La belle au bois dormant"; or, Pitting the Politics of Experience against the Sleeping Beauty Myth', Marvels o Tales 24(1): $131-151$.

Hoffman, Barbara G. (2007) 'Transgendered Translation of Mande and Maa Languages', in José Santaemilia, Patricia Bou, Sergio Maruenda and Gora Zaragoza (eds) International Perspectives on Gender and Language, Valencia, Spain: Universitat de València, 306-317.

Hosington, Brenda M. (2012) 'Translating Women in Early Modern England: Gender in the Elizabethan Versions of Boiardo, Ariosto and Tasso', Translation Studies 5(3): $372-375$.

Hu, Ying (2000) Tales of Translation: Composing the New Woman in China, 1899-1918, Stanford, CA: Stanford University Press.

Huang, Xiaoli 黄晓丽 (2006) '女性主义文学翻译中的操纵——阴道独白》个案研究' [Manipulations in Feminist Literary Translation: A Case Study on Vagina Monologues], unpublished MA course essay, Nanjing Agricultural University.

Hung, Eva (Kong, Huiyi) 孔慧怡 (1998) ‘晚清翻译小说中的妇女形象' [Women’s Image in Translated Novels in Late Qing Dynasty], 中国比较文学 [Comparative Literature in China] 2: 71-87.

- (ed.) (2005) Translation and Cultural Changes: Studies in History, Norms and Image-Projection, Amsterdam and Philadelphia: John Benjamins.

Hyun, Theresa (2004) Writing Women in Korea: Translation and Feminism in the Colonial Period, Honolulu: University of Hawai'i Press.

Jackson, Stevi (2013) 'Diana Leonard and Materialist Feminism', Gender and Education 25(1): 108-112.

Jiang, Qinglin 蒋青林 (2004) ‘论中国当代女性小说的困境与突围' [On the Plight and Breakthrough of Chinese Contemporary Feminist Fiction], 北京理工大学学报 (社会 科学版) [Journal of Beijing Institute of Technology (Social Sciences Edition)] 6(1): 51-56.

Jiang, Xiaohua 蒋骁华 (2004) ‘女性主义对翻译理论的影响’ [Influence of Feminism upon Translation Theory], 中国翻译 [Chinese Translators Journal] 25(4): 10-15.

Jiang, Xinyan (2000) 'The Dilemma Faced by Chinese Feminists', Hypatia 15(3): 140160.

Johns, Donald A. (2003) Understanding the Controversy over Gender Language in Bible Translation, Journal of Religious \& Theological Information 6(1): 43-53.

Johnson, David E. (1991) 'Woman, Translation, Nationalism: La Malinche and the Example of Juan García Ponce', Arizona Quarterly: A Journal of American Literature, Culture, and Theory 47(3): 93-116.

Journal of Feminist Studies in Religion (1989) 'Special Section on Feminist Translation of the New Testament', special issue, 8(2): 25-85.

Jun, Tang (2009) 'The Metalanguage of Translation: A Chinese Perspective', in Yves Gambier and Luc van Doorslaer (eds) The Metalanguage of Translation, Amsterdam and Philadelphia: John Benjamins, 167-182.

Kadish, Doris and Françoise Massardier-Kenney (eds) (1994) Translating Slavery: Gender and Race in French Women's Writing, 1783-1823, Kent, OH: Kent State University Press.

Kahf, Mohja (2000) 'Packing "Huda": Sha'rawi's Memoirs in the United States Reception Environment', in Amal Amireh and Lisa Suhair Majaj (eds) Going Global: The Transnational Reception of Third World Women Writers, New York and London: Garland Publishing, 148-172. 
Kamal, Hala (2008) 'Translating Women and Gender: The Experience of Translating The Encyclopedia of Women and Islamic Cultures into Arabic', Women's Studies Quarterly 36(3/4): 254-268.

Kawachi, Yoshiko (1998) 'Gender, Class, and Race in Japanese Translations of Shakespeare', in Jonathan Bate, Jill L. Levenson, Dieter Mehl, and Stanley Wells (eds) Shakespeare and the Twentieth Century, Newark, DE: University of Delaware Press, 390-402.

Keenaghan, Eric (1998) 'Jack Spicer's Pricks and Cocksuckers: Translating Homosexuality into Visibility', The Translator 4(2): 273-294.

- (2011) 'Recognizing Forbidden Pleasures', Translation Studies 4(2): 149-165.

Kinloch, David (2007) 'Lilies or Skelfs: Translating Queer Melodrama', The Translator 13(1): 83-103.

Kitamura, Yuika (2008) 'Sexuality, Gender, and The Tale of Genji in Modern Japanese Translations and Manga', in Haruo Shirane (ed) Envisioning The Tale of Genji: Media, Gender, and Cultural Production, New York: Columbia University Press, 329-357.

Krontiris, Tina (1988) 'Breaking Barriers of Genre and Gender: Margaret Tyler's Translation of The Mirrour of Knighthood', English Literary Renaissance 18(1): 19-39.

- (1992) Oppositional Voices: Women as Writers and Translators of Literature in the English Renaissance, London: Routledge.

Kubota, Noriko (2004) 'Orlando and Literary Tradition in Japan: Sex Change, Dressing and Gender in Torikaebaya Monogatari', in Natalya Reinhold (ed.) Woolf Across Cultures, New York: Pace University Press, 167-177.

Lai, Amy (2007) 'Two Translations of the Chinese Cinderella Story', Perspectives: Studies in Translatology 15(1): 49-56.

Larkosh, Christopher (1996) The Limits of the Translatable Foreign: Fictions of Translation, Migration and Sexuality in 20th Century Argentine Literature, unpublished PhD dissertation, University of California Berkeley.

- (2007) 'The Translator's Closet: Editing Sexualities in Argentine Literary Culture', TTR 20(2): 63-88.

— (ed.) (2011) Re-engendering Translation: Transcultural Practice, Gender/Sexuality and the Politics of Alterity, Manchester: St Jerome.

Lee, Jongsook (2002) 'Gender and Translation in Early Modern England', Medieval English Studies 10(2): 169-181.

Lei, Daphne P. (2009) 'The Blood-Stained Text in Translation: Tattooing, Bodily Writing, and Performance of Chinese Virtue', Anthropological Quarterly 82(1): 99-127.

Leonardi, Vanessa (2007) Gender and Ideology in Translation: Do Women and Men Translate Differently? A Contrastive Analysis from Italian into English, Bern: Peter Lang.

Levine, Suzanne J. (1983) 'Translation as (Sub)Vision: On Translating Infante's Inferno', SubStance 42: 85-94.

— (1991) The Subversive Scribe: Translating Latin American Fiction, Saint Paul, MN: Graywolf Press.

Li, Bo (2006) 'Transferred or Transformed? The Translation of Gay Literature in the Chinese Context', in Norwich Papers (University of East Anglia, UK) 14: 69-84.

_ (2013) 'The Manipulation of Images of Women in Translation in Early Twentieth Century Hong Kong Chinese Newspapers', Media History 19(3): 270-283.

Li, Hongyu 李红玉 (2008) '译者的性别意识与翻译实践——谈性别视角下的《紫色》 四译本' [Translators' Gender-consciousness and their Translation Practice: On Four Translations of The Color Purple from Gender Perspective], 中国比较文学 [Comparative Literature in China] 2: 28. 
$\mathrm{Li}$, Jiachang 李佳畅 (2008) '中国语境下的身体翻译——以《阴道独白》的两个中译本为 例' [Translating the Body in Chinese Context: A Case Study of Two Chinese Translations of The Vagina Monologues], unpublished MA dissertation, Guangdong University of Foreign Studies.

$\mathrm{Li}$, Youliang 李有亮 $(2005)$ 给男人命名一二十世纪女性文学中男权批判的流变 [To Name Men: Ideological Evolution of Criticising Men's Rights in the Twentieth Century Female Literature], Beijing: 社会科学文献出版社 [Social Sciences Academic Press].

Liang, Maocheng 梁茂成 (1996) ‘无性别歧视语言及翻译中的代词问题” [Non-sexist Language and English Translation of Chinese Pronouns], 山东外语教学 [Shandong Foreign Languages Journal] 4: 50-52.

Liao, Qiyi 廖七一 (1998) ‘跨学科综合 - 文化回归 - 多元互补一一当代西方翻译理论走 向试评' [Dimensions of Contemporary Western Translation Theory], 外国语 [Journal of Foreign Languages] 5: 26-33.

- (2000) 当代西方翻译理论探索 [An Exploration of Contemporary Western Translation Theory], Nanjing: 译林出版社 [Yilin Press].

— (2002) '重写神话: 女性主义与翻译研究” [Re-writing the Myths: Feminism and Translation Studies], 四川外语学院学报 [Journal of Sichuan International Studies University] 18(2): 106-109.

Lin, Kenan 林克难 (2000) '翻译教学在国外' [Translation Teaching Abroad], 中国翻译 [Chinese Translators Journal] 2: 56-59.

Linder, Daniel (2004) 'The Censorship of Sex: A Study of Raymond Chandler's The Big Sleep in Franco's Spain', TTR 17(1): 155-182.

Lippit, Noriko Mizuta (1988) 'Affirming the Other's Madness: Feminism in Translation'. Critical Asian Studies 20(3): 68-69.

Littau, Karin (2000) “"Pandora's Tongues”, TTR 13(1): 21-35.

Liu, Junping 刘军平 (2004) ‘女性主义翻译理论研究的中西话语' [Towards an East-West Discourse on Feminist Translation Studies], 中国翻译 [Chinese Translators Journal] 25(4): 3-9.

Liu, Siqian 刘思谦 (1993) ‘关于中国女性文学’ [On Chinese Women’s Literature], 文学 评论 [Review of Literature] 1: 61-70.

Liu, Yaru 刘亚儒 (2001) “语言的“重新性化”一一谈女权主义的翻译观” ['Resexation” of Language-On Feminist Translation View], 海南大学学报 (人文社会科学版) [Humanities \& Social Sciences Journal of Hainan University] 19(4): 69-75.

Lotbinière-Harwood, Susanne de (1991) Re-belle et infidèle: La traduction comme pratique de réécriture au féminin/The Body Bilingual. Translation as a Rewriting in the Feminine, Quebec: Les éditions du remue-ménage/Women's Press.

Luo, Linquan 罗林泉 and Mu Lei 穆雷 (trans.) (1994) ‘加拿大的翻译传统' [Canadian Translation Tradition], 语言与翻译 [Language and Translation] 1: 76-89.

Luo, Xuanmin and Hong Lei (2004) 'Translation Theory and Practice in China', Perspectives: Studies in Translatology 12(1): 20-30.

Maier, Carol (1985) 'A Woman in Translation, Reflecting', Translation Review 17(1): 4-8.

- (1998) 'Issues in the Practice of Translating Women's Fiction', Bulletin of Hispanic Studies 75: 95-108.

_ (2003) 'Gender, Pedagogy, and Literary Translation: Three Workshops and a Suggestion', in Brian James Baer and Geoffrey S. Koby (eds) Beyond the Ivory Tower: Rethinking Translation Pedagogy, American Translators Association Scholarly Monograph Series 12, Amsterdam: John Benjamins, 157-172. 
Maier, Carol and Françoise Massardier-Kenny (1996) 'Gender in/and Literary Translation', in Marilyn Gaddis Rose (ed.) Translation Perspectives IX: A Collection of Essays Situating and Proposing New Directions and Major Issues in Translation Studies, Translation Horizons Beyond the Boundaries of Translation Spectrum, New York: State University of New York, Binghamton, 225-242.

Mandrell, James (1997) “"Experiencing Technical Difficulties”: Genre and Gender, Translation and Difference: Lourdes Ortiz, Maria Antònia Oliver, and Blanca Alvarez', Journal of Narrative Technique 27(1): 55-83.

Martín, M. Rosario (2005) 'Gender(ing) Theory: Rethinking the Targets of Translation Studies in Parallel with Recent Developments in Feminism', in José Santaemilia (ed.) Gender, Sex and Translation: The Manipulation of Identities, Manchester, UK and Northampton, USA: St Jerome Publishing, 27-37.

Masiello, Francine (2002) 'Bodies in Transit: Travel, Translation, and Gender', in Daniel Balderston and Marcy Schwartz (eds), Voice-overs: Translation and Latin American Literature, Albany, NY: State University of New York Press, 213-223.

Massardier-Kenny, Françoise (1997) 'Towards a Redefinition of Feminist Translation Practice', The Translator 3(1): 55-69.

Mehrez, Samia (2007) 'Translating Gender', Journal of Middle East Women's Studies 3(1): 106-127.

Mezei, Kathy (1986) 'The Question of Gender in Translation: Examples from Denise Boucher and Anne Hébert', Tessera 3: 136-141.

- (1988a) 'Speaking White: Literary Translation as a Vehicle of Assimilation in Quebec', Canadian Literature 117: 11-23.

_ (1988b) 'Tessera, Feminist Literary Theory in English-Canadian and Quebec Literature, and the Practice of Translation as Betrayal, Exchange, Interpretation, Intervention, Transformation and Creation', in David Homel and Sherry Simon (eds) Mapping Literature: The Art and Politics of Translation, Montréal: Véhicule Press, 47-49.

- (1989) 'Traverse/ Traversée', Tessera 6: 9-10.

Mira, Alberto (1999) 'Pushing the Limits of Faithfulness: A Case for Gay Translation', in Jean Boase-Beier and Michael Hofman (eds) The Practices of Literary Translation: Constraints and Creativity, Manchester: St Jerome Publishing, 109-123.

Moi, Toril (1986) 'Feminist, Female, Feminine', in Catherine Belsey and Jane Moore (eds) $(1989 / 1997)$ The Feminist Reader: Essays in Gender and the Politics of Literary Criticism (2nd edition), Malden, MA: Blackwell Publishers, 104-116.

Morsberger, Katherine M. (1993) 'Voices of Translation: Poet's Voice and Woman's Voice', Pacific Coast Philology 28(1): 3-19.

$\mathrm{Mu}$, Lei 穆雷 (1999) ‘心弦——女翻译家金圣华教授访谈录’ [An Interview with Female Translator and Professor Jin Shenghua], 中国翻译 [Chinese Translators Journal] 2: $36-38$.

— (2002) ‘翻译界: 男性的一统天下? ——香港女翻译家孔慧怡博士访谈’ [Translation Circles: A Male Cirlces? An Interview with Hong Kang Female Translator Dr. Kong Huiyi], 西安外国语学院学报 [Journal of Xi'an Foreign Languages University] 10(2): $101-119$.

— (2003) ‘翻译与女性文学——朱虹教授访谈录’ [Translation and Women’s Literature: An Interview with Professor Zhu Hong], 外国语言文学 [Foreign Languages and Literature] 20(1): 41-44.

— (2006) ‘为翻译学事业培养人才一一第二届全国翻译学博士论坛” [A Report of the Second National PhD Forum in Translation Studies], 上海翻译 [Shanghai Journal of Translators] 4: 14-18. 


\section{Feminist translation}

$\mathrm{Mu}$, Lei et al. 穆雷等 (2008) 翻译研究中的性别视角 [Gender Perspective in Translation Studies], Wuhan: 武汉大学出版社 [Wuhan University Press].

$\mathrm{Mu}$, Lei 穆雷 and Zou Bing 邹兵 (2014) '中国翻译学研究现状的文献计量分析 (19922013)——对两岸四地近700篇博士论文的考察' [A Bibliometric Analysis of Two Decades of China's Production of Doctorate Dissertations on Translation: What the Findings Say about the Development of TS in the Country], 中国翻译 [Chinese Translators Journal] 2: 14-20.

Munday, Jeremy (2007) 'Translation Studies', Year's Work in Critical and Cultural Theory 15: 203-216.

- (2010) 'Translation Studies', Year's Work in Critical and Cultural Theory 18: 221-238.

Mwangi, Evan (2007) 'Gender, Unreliable Oral Narration, and the Untranslated Preface in Ngũgĩ wa Thiong'o's Devil on the Cross', Research in African Literatures 38(4): $28-46$.

- (2009) 'Amandina Lihamba's Gendered Adaptation of Sembene Ousmane's The Money-Order', Research in African Literatures 40(3): 149-173.

Newman, Barclay M. (2001) 'Mother Goose and Poppa Gander: Gender Faithfulness in Bible Translation', Notes on Translation 15(4): 3-16.

Niranjana, Tejaswini (1998) 'Feminism and Translation in India: Contexts, Politics, Futures', Cultural Dynamic 10(2): 133-146.

Olson, Loreen N., Tina A. Coffelt, Eileen Berlin Ray, Jill Rudd, Renée Botta, George Ray and Jenifer E. Kopfman (2008) “'I'm All for Equal Rights, but Don't Call Me a Feminist": Identity Dilemmas in Young Adults' Discursive Representations of Being a Feminist', Women's Studies in Communication 31(1): 104-132.

Palmary, Ingrid (2011) “"In Your Experience”: Research as Gendered Cultural Translation”, Gender, Place \& Culture: A Journal of Feminist Geography 18(1): 99113.

Parker, Alice (1993) 'Under the Covers: A Synesthesia of Desire (Lesbian Translations)', in Susan J. Wolfe and Julia Penelope (eds) Sexual Practice, Textual Theory: Lesbian Cultural Criticism, Cambridge: Blackwell, 322-339.

Parker, Emma (2005) 'Lost in Translation: Gender and the Figure of the Translator in Contemporary Queer Fiction', in Douglas Burnham and Enrico Giaccherini (eds) The Poetics of Transubstantiation: From Theology to Metaphor, Aldershot, UK: Ashgate, $118-25$.

Parker, Julie F. (2013) 'Blaming Eve Alone: Translation, Omission, and Implications of עמה in Genesis 3:6b', Journal of Biblical Literature 132(4): 729-747.

Pârlog, Hortensia (2007) 'Translating the Body', RRL LII(3): 325-336.

Penrod, Lynn K. (1993) 'Translating Hélène Cixous: French Feminism(s) and AngloAmerican Feminist Theory', TTR 6(2): 39-54.

Porter, Catherine (1987) 'Translating French Feminism: Luce Irigaray's Ce sexe qui n'en est pas un', in Marilyn Gaddis Rose (ed.) Translation Perspectives III, Selected Papers, 1985-86, New York: State University of New York, Binghamton, 40-52.

Potter, Anthony (1998) 'Gender and Aesthetics? Two Translations of La Respuesta', Mester 27: 17-34.

Qiao, Yigang 乔以钢 (2005) ““五四”传统与新时期女性文学” [The Tradition of “The May Fourth Movement' and the Female Literature in the New Period], 江汉论坛 [Jianghan Tribune] 7: 115-117.

Qu, Yajun 屈雅君 (2003) '女性文学批评的本土化' [Localisation of Women's Literary Criticism], in Chen Huifen 陈惠芬 and Ma Yuanxi 马元曦 (eds) 当代中国女性文学文 
化批评文选 [Selected Works of Contemporary Women's Literary and Cultural Criticism in China], Guilin: Guangxi Normal University Press, 35-39.

Reimóndez, María (2009) 'The Curious Incident of Feminist Translation in Galicia: Courtcases, Lies and Gendern@tions’. Galicia 21(1): 68-89.

— (2013) 'Of Masters and Tools', Interventions: International Journal of Postcolonial Studies 15(3): 418-434.

Ríos, Carmen and Manuela Palacios (2005) 'Translation, Nationalism and Gender Bias', in José Santaemilia (ed.) Gender, Sex and Translation: The Manipulation of Identities, Manchester, UK and Northampton, USA: St Jerome Publishing, 71-80.

Robinson, Douglas (1995) 'Theorizing Translation in a Woman's Voice: Subverting the Rhetoric of Patronage, Courtly Love and Morality', The Translator 1(2): 153-175.

Room, Adrian (1989) 'Don't Keep Sex Out of It: How to Handle a Translator's Problem', Journal of Russian Studies 56: 25-26.

Rooyen, Marlie van (2011) 'A Mediation Model for the Translation of Radio News Texts in a Multicultural Newsroom', Southern African Linguistics and Applied Language Studies 29(1): 17-29.

Sánchez, Dolores (2007) 'The Truth about Sexual Difference: Scientific Discourse and Cultural Transfer', The Translator 13(2): 171-194.

Santaemilia, José (2005a) 'Researching the Language of Sex: Gender, Discourse and (Im)Politeness', in José Santaemilia (ed.) The Language of Sex: Saying \& Not Saying, Valencia: Universitat de València, 3-22.

- (2005b) 'The Translation of Sex, The Sex of Translation: Fanny Hill in Spanish', in José Santaemilia (ed.) Gender, Sex and Translation: The Manipulation of Identities, Manchester, UK and Northampton, USA: St Jerome Publishing, 117-136.

- (ed.) (2005c) Gender, Sex and Translation: The Manipulation of Identities, Manchester, UK and Northampton, USA: St Jerome Publishing.

_ (2006) 'Researching Sexual Language: Gender, (Im)Politeness and Discursive Construction', in P. Bou (ed.) Ways into Discourse, Granada: Editorial Comares, 93-115.

— (2008a) 'Gender, Sex, and Language in Valencia: Attitudes Toward Sex-Related Language Among Spanish and Catalan Speakers', International Journal of the Sociology of Language 190: 5-26.

- (2008b) 'The Translation of Sex-related Language: The Danger(s) of Selfcensorship(s)', TTR 21(2): 221-252.

— (2011) 'Gender, Sex and Translation: Preface', in José Santaemilia and Luise von Flotow (eds) MonTI 3 Women and Translation: Geographies, Voices and Identities, 9-28.

- (2014) 'Sex and Translation: On Women, Men and Identities', Women's Studies International Forum 42, 104-110.

Santaemilia, José and Luise von Flotow (eds) (2011) MonTI 3 Women and Translation: Geographies, Voices and Identities.

Scarsi, Selene (2010) Translating Women in Early Modern England: Gender in the Elizabethan Versions of Bioardo, Ariosto and Tasso, Farnham, UK: Ashgate.

Schabert, Ina (2010) 'Translation Trouble: Gender Indeterminacy in English Novels and Their French Versions', Translation and Literature 19(1): 72-92.

Schaeffner, Christina (2013) 'Women as Translator, as Translation Trainer, and as Translation Scholars', Women's Studies International Forum 40: 144-151.

Selby, Martha Ann (2002) 'A Woman's Voice: Wendy Doniger on the Need for a New Translation of the Kamasutra', Persimmon: Asian Literature, Arts, and Culture 3(2): $32-36$. 
Sharma, Sunil (2009) 'Translating Gender: Āzād Bilgramī on the Poetics of the Love Lyric and Cultural Synthesis', The Translator 15(1): 87-103.

Sheng, Ying 盛英 (1994) '20世纪中国女性文学特征' [The Characteristics of Chinese Women's Literature in the Twentieth Century], 妇女研究论从 [Collection of Women's Studies] 2: 41-45.

Shread, Carolyn (2007) 'Metamorphosis or Metramorphosis? Towards a Feminist Ethics of Difference in Translation', TTR 20(2): 213-242.

Simon, Sherry (1996) Gender in Translation: Culture and Identity and the Politics of Transmission, London and New York: Routledge.

Simons, Margaret A. (1983) 'The Silencing of Simone de Beauvoir: Guess What's Missing from The Second Sex', Women's Studies International Forum 6(5): 559564.

Showalter, Elaine (1977) A Literature of Their Own: British Novelists from Brontë and Lessing, Princeton: Princeton University Press.

Smith, Janet S. Shibamoto (2005) 'Translating True Love: Japanese Romance Fiction', in José Santaemilia (ed.) Gender, Sex and Translation: The Manipulation of Identities, Manchester, UK and Northampton, USA: St Jerome Publishing, 97-116.

Snyder, R. Claire (2008) 'What is Third-Wave Feminism? A New Directions Essay', Signs 34(1): 175-196.

Spencer, Aida Besançon (2003) 'The Translation Issues in the Gender Inclusive Controversy', Journal of Religious \& Theological Information 6(1): 11-23.

Spivak, Gayatri (1992) 'The Politics of Translation', in Michèle Barrett and Anne Philipps (eds) Destabilizing Theory: Contemporary Feminist Debate, Stanford: Stanford University Press.

Spurline, William J. (2014a) 'Queer Translation', in Sandra Bermann and Catherine Porter (eds) A Companion to Translation Studies, Oxford: Wiley Blackwell, 299.

— (2014b) 'The Gender and Queer Politics of Translation: New Approaches', Comparative Literature Studies 51(2): 201-214.

Stahl, Aletha (2000) 'Does Hortense Have a Hoo-Hoo? Gender, Consensus, and the Translation of Gisèle Pineau's L'Espérance-Macadam', TTR 13(2): 127-148.

Sun, Yifeng (2012) 'The Shifting Identity of Translation Studies in China', Intercultural Communication Studies XXI(2): 32-52.

Susam-Sarajeva, Şebnem (2005) 'A Course on "Gender and Translation": As an Indicator of Certain Gaps in the Research on the Topic', in José Santaemilia (ed.) Gender, Sex and Translation: The Manipulation of Identities, Manchester, UK and Northampton, USA: St Jerome Publishing, 161-176.

Taylor, Susan B. (2000) 'Feminism and Orientalism in Elizabeth Hamilton's Translation of the Letters of a Hindoo Rajah', Women's Studies: An Inter-Disciplinary Journal 29(5): $555-581$.

Tessera (1989) 'La traduction au féminin/Translating Women', special issue, 6.

Tian, Yu 田雨 and Ma Yao 马尧 (2004) '开阔的理论视野, 强烈的学科意识——首届全 国翻译学博士论坛学术综述” [A Report of the First National PhD Forum in Translation Studies], 中国翻译 [Chinese Translators Journal] 25(4): 55-56.

Translation Review (1985) 'Women in Translation', special issue, 17.

Vinay, Jean-Paul and Jean Darbelnet (1958/1995) 'A Methodology for Translation', in Lawrence Venuti (ed.) (2000) The Translation Studies Reader, London and New York: Routledge, 84-93.

Voldeng, Evelyne (1984) 'TransLata/Latus', Room of One's Own: A Feminist Journal of Literature and Criticism 8(4): 82-96. 
Wahrman, Dror (1999) 'Gender in Translation: How the English Wrote Their Juvenal, 1644-1815', Representations 65: 1-41.

Wakabayashi, Judy (2003) 'Out of the Shadows: Applying a Feminist Framework to Translation in Meiji and Modern-Day Japan', PAJLS: Proceedings of the Association for Japanese Literary Studies 4: 195-206.

Wallace, Melissa (2002) 'Writing the Wrongs of Literature: The Figure of the Feminist and Post-Colonialist Translator', The Journal of the Midwest Modern Language Association 35(2): 65-74.

Wallmach, Kim (1998) 'Translation and Gender: Interconnections'. Language Matters: Studies in the Languages of Africa 29(1): 5-25.

— (2006) 'Feminist Translation Strategies: Different or Derived?', Journal of Literary Studies 22(1/2): 1-26.

Wang, Hong 王宏 (2007) ‘多元互补和谐共进——2006年全国翻译高层研讨会综述” [A Report of 2006 National Translation Symposium], 上海翻译 [Shanghai Journal of Translators] 1: 18-19.

Wang, Jianguo 王建国 and Jia Jia 贾佳 (2001) “翻译文学中的女权主义创造性叛逆” [On Feminist Creative Infidelities in Translation Literature], 广东外语外贸大学学报 [Journal of Guangdong University of Foreign Studies] 5: 57-60.

Wang, Ning and Sun Yifeng (eds) (2008) Translation, Globalisation and Localisation: A Chinese Pespective, Clevedon, UK and Buffalo, NY: Multilingual Matters.

Wang, Wen 汪雯 (2007) '女性主义翻译理论关照下的《阴道的独白》的喻荣军中译本剖 析' [Feminist Translation of The Vagina Monologues into Chinese by Yu Rongjun], unpublished MA course essay, Nanjing Agricultural University.

Weber, Orest, Pascal Singy and Patrice Guex (2005) 'Gender and Interpreting in the Medical Sphere: What is at Stake?', in José Santaemilia (ed.) Gender, Sex and Translation: The Manipulation of Identities, Manchester, UK and Northampton, USA: St Jerome Publishing, 137-148.

Weber, Wendolyn (2012) 'Transmitting Fantasies: Sexist Glossing, Scholarly Desires, and Translating the Heroic Woman in Medieval Germanic Literature', Translation Studies 5(3): 312-326.

Webster's New Millennium ${ }^{\mathrm{TM}}$ Dictionary of English, Preview Edition (v 0.9.7) (2006) 'metatext', Dictionary.com website: http://dictionary.reference.com/browse/meta-text (last accessed on 7 August 2008).

Wells, Will (2013) 'Keep Faith: Translating the Poems of Sarra Copia Sulam', Shofar: An Interdisciplinary Journal of Jewish Studies 31(3): 131-144.

West, Kevin (2010) 'Translating the Body: Towards an Erotics of Translation', Translation and Literature 19(1): 1-25.

Wheeler, Anne-Marie (2003) 'Issues of Translation in the Works of Nicole Brossard', The rale Journal of Criticism 16(2): 425-454.

Wolf, Michaela (2005) 'The Creation of a "Room of One's Own": Feminist Translators as Mediators between Cultures and Genders', in José Santaemilia (ed.) Gender, Sex and Translation: The Manipulation of Identities, Manchester, UK and Northampton, USA: St Jerome Publishing, 15-25.

Women's Studies International Forum (2014) 'Rethinking Women and Translation in the Third Millennium', special issue, 42.

Wong, Lawrence Wang-Chi (Wang Hongzhi) 王宏志 (1999) ‘重释“信、达、雅”一 二十世纪中国翻译研究' [Re-interpreting 'xin, da, ya': Study of Translation in China in the Twentieth Century], Shanghai: 东方出版中心 [Orient Publishing Centre].

Woods, Michelle (2011) 'Reassessing Willa Muir', Translation Studies 4(1): 58-71. 
Xie, Tianzhen 谢天振 (1999) 译介学 [Medio-translatology], Shanghai: 上海外语教育出 版社 [Shanghai Foreign Language Education Press].

$\mathrm{Xu}$, Baoqiang 许宝强 and Yuan Wei 袁伟 (eds) (2001) 语言与翻译的政治 [The Politics of Languages and Translation], Beijing: 中央编译出版社 [Central Compilation \& Translation Press], 309-357.

Xu, Lai 徐来 (2004) ‘在女性的名义下重写' [Rewriting in the Name of Feminine: The Significance of the Feminism Translation Theory in the Study of the Translator's Subjectivity], 中国翻译 [Chinese Translators Journal] 25(4): 16-19.

Yan, Chunde 阎纯德 (1998) '20世纪中国女性文学的发展' [The Development of Chinese Feminist Literature in the Twentieth Century], 文学评论 [Review of Literature] 4: 69-76.

Yan, Fu (trans.) (1981) 天演论 [On Evolution], Beijing: 商务印书馆 [The Commercial Press].

— (trans.) (2002) 天演论 [On Evolution], Beijing: 华夏出版社 [Huaxia Press].

Yan, Jianhua 间建华 and Liu Jiangang 刘建刚 (2002) '性别差异与翻译: 解读女权主义 的翻译观' [Sex Difference and Translation: A Dialectical Study of Feminist Opinions on Translation], 浙江工业大学学报 [Journal of Zhejiang University of Technology] 30(6): 594-597.

Yoshihara, Mari (2004) 'Putting on the Voice of the Orient: Gender and Sexuality in Amy Lowell's “Asian" Poetry', in Adrienne Munich, Melissa Bradshaw and Jane Marcus (eds) Amy Lowell, American Modern, New Brunswick, NJ: Rutgers University Press, 120-35.

Yu, Zhongli (2011) 'Gender in Translating Lesbianism in The Second Sex', in José Santaemilia and Luise von Flotow (eds) MonTI 3 Women and Translation: Geographies, Voices and Identities, 421-445.

Yuan, Xidi 袁夕娣 (2008) ‘表演性和戏剧翻译: 兼论《阴道独白》的两个中译本' [Performability and Drama Translation: With an Analysis of the Two Chinese Versions of The Vagina Monologues], unpublished MA dissertation, Nanjing Agricultural University. Yue, Ming-Bao (2000) “"Am I That Name?”: Women's Writing as Cultural Translation in Early Modern China', Comparative Criticism 22: 63-89.

Yusupova, Marina (2014) 'Pussy Riot: A Feminist Band Lost in History and Translation', Nationalities Papers: The Journal of Nationalism and Ethnicity 42(4): 604-610.

Zeng, Lixin 曾丽馨 (2008) '性别差异与翻译——管窥《紫色》男女译者的译著特征' [Gender Differences and Translation-Characteristics of the Translations of The Color Purple by Male and Female Translators], 湖州师范学院学报 [Journal of Huzhou Teachers College] 30(3): 109-113.

Zhang, Jinghua 张景华 (2004) ‘女性主义对传统译论的颠覆及其局限性' [On the Contribution and Limitations of Feminist Translation Theory], 中国翻译 [Chinese Translators Journal] 25(4): 20-25.

Zhang, Longxi (1998) Mighty Opposites: From Dichotomies to Differences in the Comparative Study of China, Stanford: Stanford University Press.

Zide, Arlene R. K. (1994) 'Normative Canons, Women's Language, and Translation of the Other', in Alice Davison and Fredereick M. Smith (eds) Papers from the Fifteenth South Asian Language Analysis Roundtable Conference 1993, Iowa City, IA: South Asian Studies Program, University of Iowa, 409-428.

Zoberman, Pierre (2014) “ "Homme” peut-il vouloir dire "Femme”?: Gender and Translation in Seventeenth-century French Moral', Comparative Literature Studies 51(2): 231-252.

Zwarg, Christina (1990) 'Feminism in Translation: Margaret Fuller's Tasso', Studies in Romanticism 29(3): 463-490. 


\section{Contextualising the Chinese translations of The Second Sex and The Vagina Monologues}

This chapter looks into what type of works The Second Sex (TSS) and The Vagina Monologues (TVM) are, what they are about, what responses they have received, when and why they are translated, on which English version each translation is based, who the translators are, and what the Chinese translations look like. All these help explain why the Chinese translators deal with the materials on the female body and female sexuality in certain ways and why censorship operates in different degrees in different translations.

\subsection{Le Deuxième Sexe and The Second Sex}

Le Deuxième Sexe (LDS) was published in 1949 in France and its first English translation The Second Sex (TSS) was published in 1952. A twentieth-century classic and a pivotal analysis of women's oppression by men, TSS is 'a complex work of theoretical philosophy', as well as a brilliant and persuasive polemical work (Evans 1998: 1). Today it remains a foundational text in philosophy, feminism, and women's studies (Simons 1995, 1998 and 2006, Lennon 2010, Mussett 2010, Bauer 2011). In this voluminous book, Beauvoir explores the historic situation of women and makes a scholarly and passionate plea for the abolition of the myth of the eternal feminine (i.e. the vague and basic essence of femininity). The book begins with her question 'What is woman?' to which she answers initially that woman is defined as that which is not man-as other. In the end, she concludes that women have been prevented from taking active control of their own lives and been unfree throughout history. Woman was subjected to man who, partly with woman's consent, made her merely an extension of himself. Men and women have never shared an equal relationship. Changing this situation would be advantageous to all (Vintges 1996: 21, Kruks 1998: 58).

This massive work draws upon materials from a wide range of disciplines, including philosophy, biology, anthropology, psychology, sociology, literature, and history. It runs to about a thousand pages of close print and is divided into two volumes, with the first volume being more academic than the second. Each volume is composed of a number of sections organised into chapters. Book I Les faits et les mythes [Facts and Myths] talks about women from the perspective of biology, psychology, history, and literature. It contains an introduction and 
three sections: 'Destin' [Destiny] dealing with the biological, psychoanalytical, and Marxist views of women; 'Histoire' [History] giving an account of women's position in society over the centuries; and 'Mythes' [Myths] analysing archetypal representations of women. In the introduction, Beauvoir explains the theoretical framework in a nutshell and attacks the concept of 'l'éternal féminin' [the eternal feminine] that constitutes her underlying target throughout her book. According to Beauvoir, there is a series of myths about woman that contributes to the formation of the myth of the eternal feminine. The series of myths include the myth of the mother, the virgin, the motherland, and nature. The eternal feminine (the sanctity of the mother, the purity of the virgin, and the fecundity of the earth and of the womb) serve to deny the individuality and situation of all different kinds of women, thereby trapping women into embracing certain impossible ideals. Book II L'expérience vécue [Woman's Life Today] deals with woman's life from childhood to old age; predicaments of marriage; motherhood; lesbianism; prostitution; escapes into narcissism, religion and love; and possibilities of independence. It comprises four sections: 'Formation' [The Formative Years] (examining the upbringing and development of women), 'Situation' [Situation] (analysing the characteristic situations that women face in society), 'Justifications' [Justifications] (discussing certain broad types of reaction to the oppression involved), and 'Vers la libération' [Towards Liberation] (talking about the pitfalls and possibilities that await the independent woman trying to find a way forward) (Beauvoir 1975: 195, Keefe 1983: 95, Vintges 1996: 26, Lennon 2010, Mussett 2010).

Due to its richness and its multi-faceted nature, TSS has provoked a range of varying responses, each reflecting the characteristic interest of its time, and there is no reason to believe that this process has been completed (Pilardi 1995, Fullbrook and Fullbrook 1998: 117). For instance, upon its appearance, while being praised for its seriousness and stylistic excellence (Fullbrook and Fullbrook 1998: 117), TSS was dismissed as 'one-sided and tendentious', and Beauvoir herself was labelled a 'man-hater', or 'nymphomaniac' (Bair 1990: 21). TSS has been said to mime phallogocentric thinking (Evans 1998: 5), contain 'a male view of women', and be 'in opposition to the female body' (Bair 1990: 22 and 45). Moreover, TSS was labelled a careless work, unsystematic in structure, overtaken by the facts (Vintges 1996: 21), and lack of 'specific plans for accomplishing the liberation of women from patriarchal oppression' (Pilardi 1995: 31). Some feminist philosophers regard TSS as 'heterosexist, maculinist and Sartean' (Simons 1999: 115). ${ }^{1}$ Over time, positive responses have grown. Pilardi (1995: 30) points out that the power of TSS resides in Beauvoir's notion of woman as the Other. Beauvoir's central arguments are that women are forced by patriarchy into immanence and denied freedom by men. Since Beauvoir's notion of otherness is dialectical, the book concerns not just woman, but man as well; that is, it concerns humanity under patriarchy or gender. TSS is regarded as Beauvoir's weightiest work on social and historical dimensions (Keefe 1983: 116), and the source of the twentieth-century women's movement (Patterson 1992: 41). 
The first English translation from French was published in 1952, a translation by a professor of zoology Howard M. Parshley (1884-1953). Parshley's translation of TSS appeared to be a great success, making the New York Times bestseller list soon after its publication in America. It came to be considered the most ambitious and brilliant study of women ever written. Beauvoir was greatly satisfied to see the 'fortune' of TSS changed once it was published in America and Britain (Pilardi 1995: 39), unlike in France where it was 'unsoiled by any salacious comment' (Beauvoir 1975: 298). Since its publication, the translation has sold 'too well to go out of print' (Moi 2002: 1030, 1032).

However, little glory has accrued to the translator. On the contrary, Parshley becomes a controversial figure among Beauvoir scholars who are dissatisfied with the translation (Gillman 1988), such as Simons (1983), Fallaize (2002), and Moi $(2002,2008)$. Parshley has not only been severely criticised for the quality of his translation, but even suspected of ideological bias (Keefe 1994: 20). Simons (1983) was the first one who cogently criticised Parshley's translation. Simons points out that in the translation, without indication, over ten per cent of the material in the French original has been deleted, including fully one-half of a chapter on history, one-quarter of another, the names of seventy-eight women in history and almost every reference to socialist feminism. Moreover, key philosophical terms are mistranslated, which is said to 'compound the confusion'. These non-indicated deletions and mistranslations 'seriously undermine the integrity of Beauvoir's analysis of some important topics such as the American and European nineteenth-century suffrage movements and the development of socialist feminism in France', 'obscure the philosophical context of Beauvoir's work and gives the mistaken impression to the English reader that Beauvoir is a sloppy writer and thinker' (Simons 1983: 559-560, 1999: xviii). These critical comments have been quoted by many scholars, such as Flotow (1997).

In order to 'alert' readers to the shortcomings of the English translation, Moi (2002) further discusses Parshley's cuttings, omissions and misunderstandings in much more detail, and illustrates her criticism with many examples (Moi 2002, 2008). She points out how damaging the translation is 'to Beauvoir's intellectual reputation in particular and to the reputation of feminist philosophy in general' due to the translator's philosophical incompetence. She argues that 'the translation at times makes it difficult to discover what Beauvoir actually thought about important feminist issues' (Moi 2002: 1005). Fallaize (2002) criticises the cuts and omissions in the chapter 'The Married Women'. Beauvoir herself was also very unhappy when she knew the problems in the English translation, saying that it was a 'gross error to have translated it in that way' and she 'would like very much for another translation of The Second Sex to be done, one that is much more faithful, more complete and faithful' (Simons 1982/1999: 59, 1985/1999: 94). Many feminist and Beauvoir scholars wondered why a male professor of biology with no apparent expertise in French was selected to translate such a feminist and philosophical book (Patterson 1992: 41).

Patterson's article 'Who Was this H. M. Parshley?' answers the question. According to Patterson, Parshley received a solid academic background when 
young, including the study of classical and modern languages at Boston Latin School. Parshley obtained his Doctoral of Science degree in Entomology in 1917 from Harvard University. Dissatisfied with studying insects only, he branched out into an analysis of some of the broader aspects of science and wrote The Science of Human Reproduction: Biological Aspects of Sex in 1933. This study elicited an invitation to lecture at a national Birth Control and Population Conference in Washington D.C. in January 1934, and later to advise the publisher Alfred A. Knopf whether LDS should be translated into English. Parshley found that the book was a profound and unique analysis of woman's nature and position, eminently reasonable and often witty, and concluded that it definitely merited translation and publication in America. He was subsequently assigned to the translation work, as his academic background in both Latin and French left the publisher in no doubt of his ability to translate French (Patterson 1992: 41-42).

In the translator's preface, Parshley explained why and how he translated the book. He undertook the arduous task because he had long been concerned with certain scientific and humanistic aspects of the subject. In $L D S$, Beauvoir employs a kind of informal style, which is for the most part precise and sometimes elevated and poetic. Parshley conceived it his duty to adhere faithfully to what Beauvoir had said and to maintain to the best of his ability the mood she had created. Therefore, he intended to avoid all paraphrasing not required by language differences and to provide an exact and complete translation, with slight exceptions. Occasionally, at the publisher's request, he added an explanatory word or two (especially in connection with existentialist terminology), and provided a few additional footnotes and bibliographic data that he thought might be of interest to the reader. He also cut and condensed here and there for brevity, chiefly in reducing illustrative material, especially in her quotations from other writers. He declared that all such modifications had been made with Beauvoir's permission, passage by passage (Parshley in Beauvoir 1972: 7-12).

Parshley's preface conveys several messages: he tried to keep faithful to the French original; he obtained permission from Beauvoir for all the modifications; some changes are made at the request of the publisher; and some changes are made for the interest of the reader. Obviously, the reader here means the general reader, rather than the specialist reader. It seems these messages did not catch the attention of the critics. And, when criticising Parshley's translation in their critical papers, the critics, by and large, seem to be aware of the constraints imposed by the publisher under which Parshley carried out the translation. Unfortunately, Parshley died soon after the publication of his translation, leaving him no chance either to enjoy the popularity of his translation or to meet the criticisms.

Gillman, a freelance writer and neighbour of Parshley, wrote to defend Parshley in The New York Times (1988). Apparently, his defence has also been largely ignored by many critics. Fortunately, Parshley's correspondence with the publisher and Beauvoir tells the story of the formation of the translation. His daughter Elsa Parshley Brown made available to scholarly examination the voluminous 
correspondence between Parshley and Knopf. After a careful examination of the correspondence, Patterson explains why Parshley was selected to translate, and tells of Parshley's struggle with the publisher over the publisher's requirement of cutting and omitting, and of Beauvoir's slow and sparse response to Parshley's questions regarding the cuts and omissions (Patterson 1992). Bogic's recent study of the correspondence further reveals Parshley's struggle with Beauvoir's philosophical concepts, the questionable role of the publishers, and the lack of much needed contact between Parshley and Beauvoir during the translation process itself (Bogic 2009, 2011).

Bogic's studies signify that Parshley's translation may receive more objective comments in translation studies where scholars have long been aware of the complicated factors, i.e. 'paratranslation' factors, in the making of a translation product. Paratranslation means an analytical environment for studying the 'ideological adaptation undergone by any cultural product in order to be incorporated to the target culture wealth'. The criticisms of the English translation, the reasons behind the problems charged by the critics, and the role 'paratranslators' (who could be sponsors, patrons or editors) play in the translation process again indicate that a translation is seldom an autonomous or independent operation by the translator alone, but a result of many factors with the translator as the executor. It is often not fair to criticise the translator alone for all the problems in a translation without considering 'paratranslation' factors (Vazquez 2008: 133). TSS is a typical example of this. The interesting phenomenon that TSS sells very well in spite of all the criticisms regarding the cuts and omissions reflects different needs of general readers and researchers. Therefore, retranslations are always necessary to meet different or changing needs of readers, and such needs and translation purposes are important factors to consider in translation studies.

Parshley's translation was the only English translation until 2009, but its different editions were published in America and Britain and in different years, and contain some differences. For instance, the edition published in Britain is surprisingly not a full reprint of the American edition, with further cutting and editing. Some citations are cut and some words are changed. On page 453 in the 1984 Penguin reprint, a case from Stekel is gone (cf. Beauvoir 1993: 455-456); and the last word of the second paragraph in 'The Married Woman' is changed from 'itself' into 'in part' (Beauvoir 1972: 455, 1993: 448). It is not clear why and by whom such changes are made in the British reprint. In addition, in the 1993 American edition, the translator's preface disappears, and instead, an introduction by Margaret Crosland is added. Since the Chinese translations are based on either the American or the British editions, all these contribute to some of the differences between the various Chinese translations.

For decades, both Moi and Simons have called in vain for 'a new, authoritative translation', a 'fresh, complete, and correct translation' to remedy the 'problems' in the first English translation (Simons 1983: 564, Moi 2002: 1033). In 2007, Random House, Beauvoir's publisher in the United States, finally 
announced that a new English translation had been commissioned (Moi 2008) to celebrate the sixtieth anniversary of the publication of LDS (Liu Kunya 2009). The longed-for new translation (by Constance Borde and Sheila MalouvanyChevallier) came out in America at the end of 2009, but immediately received an even more severe criticism by Moi (2010), who claimed that the new translation was even worse. Later Bauer (2011) and Parker (2011) also expressed disappointment to the new translation. As it has nothing to do with the Chinese translations in question, I will not dwell on the new English translation here.

\subsection{Chinese translations of The Second Sex}

TSS informally arrived in China in the late 1970s, shortly after the Cultural Revolution (1966-1976), when a Taiwan translation of Book II was circulating privately among Mainland readers. This was the usual way in which Chinese readers in the Mainland had access to a translation of a Western literary or philosophical work at that time, especially during the Cultural Revolution (Dai Jinhua 2007: 37). From 1986, Chinese readers could have access to TSS through bookstores and libraries. The first Chinese translation was published in the Mainland in 1986, which is a reprint from a Taiwan version by Sang Zhuying and Nan Shan (Tao Tiezhu 1998: 2). This reprint is a translation of Book II Women's Life of Today, published with the title of 第二性一女人 [ The Second Sex-Women]. The added 'women' has rich meaning in that particular time in China (discussed in Chapter Seven). In Book I Facts and Myths, Beauvoir discusses women from the viewpoints of biology, psychoanalysis, and economic philosophy, and elaborates on the historical changes of Western women's position from primitive times to after the French Revolution and the various myths about women. This part was not translated because it mainly consists of scholarly theories (Sang Zhuying and Nan Shan 1986: 1), which suggests the publisher's marketing considerations by targeting more general readers. There is no indication of the source text in the translation. A comparison of this translation with American and British editions indicates that this is a translation from an American edition.

It is not an accident that the first Chinese translation of TSS is a reprint of a previous translation. It was a common practice at that time when the whole nation was thirsty for reading and the publisher could not immediately provide new books (translated or domestic) to meet the great need (see 7.2). At such time, every book sold well, even often sold out in a short time (Anonymous 2008). The Chinese translation of the big and difficult TSS was no exception. Once published, this translation became a popular book among female university students of that time (Li Qiang 2004: Translator's Preface) and exerted much influence in academia, particularly on Chinese female literature and the development of feminist literary criticism (Chen Xiaoli 2009: 50).Yet, according to Tao Tiezhu, this reprint has some demerits. It contains terms typically used in Taiwan, different from those used in the Mainland, which may cause a hindrance to smooth reading and understanding for Mainland readers. For instance, 'proletarian' is transliterated into 'puluo dazhong 普罗大众' rather than '无产者' 
[proletarian]. ${ }^{2}$ Moreover, some philosophical expositions are deleted. There are also some mistranslations that are misleading to readers (Tao Tiezhu 1998: 2).

The success of the 1986 translation may have encouraged the publisher to bring out a Mainland translation to make the reading process smoother for Mainland readers. In 1988, another translation of Book II by Wang Youqin and Qiu Xichun et al. came into being, a translation based on the 1983 English version in the Penguin Modern Classics series. It may also be due to marketing considerations that the 1988 translation still does not include Book I. In the translation, there are several sections and parts deleted: 'The Lesbian', 'Prostitutes and Hetairas', 'Justifications' and 'Towards Liberation'. In the 1980s, homosexuality and prostitution were unknown to the majority of ordinary Chinese people. Homosexuality was something generally unimaginable and unacceptable at that time while prostitution was supposed not to exist since it was officially extinguished soon after the founding of the People's Republic of China. Understandably, the sections on lesbian and prostitutes were deleted because they were entirely out of context in China (see Chapter Seven for more discussion). 'Justifications' discusses certain broad types of reaction to the oppression involved, and 'Towards Liberation' talks about the pitfalls and possibilities that await the independent woman trying to find a way forward. Both chapters are based on the French context, which may have been regarded as less interesting to Mainland readers and thus were cut. Because the parts translated deal with the whole life of a woman and answer the question 'What is woman?', the translation is renamed as '女人是什么' [What is Woman?] (Wang Youqin and Qiu Xichun et al. 1988: 441). Tao Tiezhu (1998: 2) praises this version as being much more accurate and fluent than the one by Sang Zhuying and Nan Shan, but it has the same problem as the first translation, i.e. it is still a partial translation of TSS.

The first Chinese translation of Book I came out one month after the 1988 translation of Book II was published. Seeing that the 1986 translation of Book II was well received upon publication, the translators thought it a great pity for the readers to have no access to a Chinese version of Book I. Hence, they produced the translation of Book I so the reader could have a deeper and more comprehensive knowledge of Beauvoir's thoughts and for all the Chinese readers concerned about women (Xiao Yi et al. 1988: 4). In this version, Part II History (about one fifth of Book I) is deleted. Beauvoir thinks that the history of woman in the East (such as in India and China) has been that of a long and unchanging slavery, and therefore, her study focuses on the West, especially on France where she thinks the situation is typical (Beauvoir 1993: 86). It may just be this French focus that led to the translators' or the editor's decision to delete the history part, because it may not be interesting to general Chinese readers. The rest of the two parts are much edited and condensed, making the final translation a small book of just over 200 pages. The rationale must be that general readers can hardly feel interested in the lengthy abstruse academic discussion in Book I, such as the biological discussion of animal sexes. The editing and deletion should have more to do with market consideration. It is interesting to see that 
the translation of Book I, which mainly consists of scholarly theories, was given a very exoteric and eye-catching title '女性的秘密’ [Female Secrets]. On its cover is a beautiful female figure, with her naked arm on a man's face in the dark, also showing marketing consideration. This translation was produced by Xiao Yi, Zhang Yali and eight other translators, i.e. as many as ten people were involved in the translation. It is not clear how the work was divided among the ten and whether the editing was decided by the editor or by the translators. Due to the fact that this is their 'first attempt at translating', their translation may have been much guided or directed by the editor (Xiao Yi et al. 1988: 5). The fact that 'ten' translators produced such a small volume may imply another story, which is outside of the scope of this research.

In 1998, the first 'complete' Chinese translation was published, a translation by Tao Tiezhu, with one section 'The Myth of Women in Five Authors' translated by Kang Zhengguo. Tao Tiezhu was a researcher in women's studies. He stated in the translator's preface that he translated it to provide a reference for and meet the needs of women's studies in China, which had been expanding over the decade. Advised by specialists, he adopted a strict literal translation approach, except in a very few cases where some alternatives had to be used to express exactly what the source text meant. He adopted this strategy to maintain the original feature of TSS and keep faithful to the message of TSS, respecting the reader's right to understand TSS (Tao Tiezhu 1998: 5-6). Although it is claimed to be a complete translation, as it is based on the 1953 English translation which is not complete in itself, Tao's translation is not complete in the strictest sense (Chen Huan 2004, Shen Ke and Xu Jun 2009: 203).

In 2004, an abridged translation (by Li Qiang) of the 1974 edition by Vintage Books was published. It covers every part except the short section 'The Mystic'. In the translator's preface, Li Qiang explains why such an abridged version is necessary. As a theoretical classic of Western feminism, TSS is a great book containing complicated subjects, difficult to follow in some parts. A general reader can hardly read through the whole book. Therefore, he selects what he considers to be the essence to translate, believing that this abridged translation provides the main ideas and brilliance of TSS to enable the reader to appreciate Beauvoir's outstanding talents as well as her far-sightedness concerning women's fate and their future (Li Qiang 2004). This translation was published as one in a series of Western philosophical and theoretical translation works, which gives the translation an academic appearance. However, the reason for the abridged version that the translator gives in the translator's preface shows that the translation is in fact targeted at general readers. In this version, a large proportion of descriptions, analysis and illustrations of women's life experience are cut. These cuts seem justified by the fact that TSS is seriously lacking multiculturalism or cultural diversity (Pilardi 1995: 38). In Okely's words, TSS is a local study, in part an anthropological village study of specific women, with the village being largely mid-century Paris and the women studied mainly middle class (Okely 1998: 21). Therefore, the cuts could be the editor's or publisher's idea for attracting a larger readership so as to maximise profits, since the deleted 
descriptions, analysis and illustrations of women's life experience are exclusively Western, which general readers in China might not be interested in. It is true that the idea of universal sisterhood was the great appeal of feminism at that time. Nevertheless, economic consideration, rather than universal sisterhood, seems to dominate in the editorial process.

Five years later, another two abridged translations of TSS appeared. A careful comparison of the two 2009 versions shows that they are identical in most parts. Most importantly, although published with different titles (one with 第二性女 人 [The Second Sex Women] and the other with 第二性 [The Second Sex]), under the names of different translators (one is Tang Yi and the other Shu Xiaofei), and in different months by different publishers (Beijing Yanshan Press and Xiyuan Publishing House), all the evidence seems to suggest that these two versions are virtually reproduced from the 2004 abridged translation, with some further chapters deleted: 'Through the Middle Ages to Eighteenth Century France' and 'Since the French Revolution: The Job and the Vote' in Book I, and 'Prostitutes and Hetairas', 'Justifications' and 'Towards Liberation' in Book II. ${ }^{3}$ The deleted chapters are mainly based on French stories from past times, and therefore may generate little reading interest among Chinese readers who do not have much knowledge of them. Thus the deletion may be done to lighten the burden for Chinese readers, just as the publisher Knopf did for American readers (Patterson 1992: 43). On the other hand, cutting potentially uninteresting chapters can reduce the cost and price of the book, increasing sales, and ultimately producing more profit for the publisher. This deletion also indicates that the copies are targeted at general readers, although they appear to be sophisticated, because on the covers the publishers indicate that they are among a series of either '世界经典名著' [The World’s Classic Masterpieces] or ‘西方大师的智慧' [Wisdom of the Western Great Masters]. What is odd is that one of the 2009 copies is produced by the same publisher (Xiyuan Publishing House) as that of the 2004 translation. It is even odder that the same reproduction was printed in the name of another translator (perhaps non-existent) by another publisher (Beijing Yanshan Press) in the same city (Beijing) almost at the same time. These two have little value for textual analysis in this study and thus are not included in the translation analysis in Chapters Four, Five, and Six. But they at least indicate continued interest in, a good market for, and a considerable profit to be gained from TSS.

To summarise, up until 2009, at least seven Chinese translations of TSS had been published in Mainland China, if the two 2009 versions are counted as translation. The translations of the 1980s are no longer available, with only a few copies in some university libraries. Tao's translation, reprinted in 2004, is generally available in libraries and on the market, and is the one most often referred to in relevant research works. As described above, these translations are all partial to some extent, and all based on the first English translation. The 'defective' English source inevitably undermines the credibility of all the Chinese translations. However, the controversy over the English translation has received little attention in China, not only in the fields of philosophy, sociology, and 
humanity and arts, but also in translation studies, except for a few references to the problems in the English translation to justify a new Chinese translation from the French original, such as Chen Huan 2004, Liu Kunya 2009, and Shen Ke and Xu Jun 2009. In 2004, Shanghai Translation Publishing House initiated a new Chinese translation from the French original. Similar to the case in America, the new Chinese translation was intended to be published in 2008 for the one-hundredth anniversary of Beauvoir's birth, but did not come out until 2011. It is claimed to be 'the first and only complete Chinese translation from the French original', and almost immediately, in 2012, the translator Zheng Kelu, a professor of French Literature, was awarded the fourth '傅雷翻译出版 奖' [Fu Lei Translation Publication Prize] (Chen Tao 2012, Zheng Kelu 2012). This translation came out when the research for this book had been completed, and hence is not included in the analysis. Hereafter 'the English translation' refers to Parshley's translation only.

\subsection{The Vagina Monologues}

TVM is a bold feminist dramatic work produced by Eve Ensler, a radical feminist and a playwright. It was published in 1998, and revised into a V-day version in 2001. It explores women's bodies and sexuality, unveils truths, not usually told, about the vagina, and reminds people how women have felt and been abused (physically, emotionally, and sexually) and what has caused women to neglect such an important part of their bodies as their vaginas. It reveals unequal power relations between men and women by exposing the horrible aspects of female disempowerment and the magnitude of violence and abuse that takes place towards women in the world today, such as rape, sexual abuse, and genital mutilation. Although feminism has existed for more than 100 years and 'body work' started in the 1970s, this dramatic work still produced great shock and sensation when published in the late 1990s, shock which continues to be felt wherever it goes in the world. This to some extent shows how difficult it is to change traditional views about women, especially women's bodies and sexualities.

Ensler's own experience of sexual abuse in her childhood led to her concern with women's bodies and sexualities. She interviewed over 200 women from all over the world regarding their vaginas. Ensler believes that how women regard this organ is deeply connected to the state of women in the world (Braun and Ensler 1999: 517). Through investigating what happened to women, especially their vaginas, and how women treat their own bodies, Ensler tries to reclaim women's sexual organs from denigration, to draw people's attention to sexual violence against women in order to stop it, and advocates women's right to enjoy sexuality. She openly talks about women's experiences that have never been talked about, such as women's sexualities, desires, and vaginas, topics that have been taboo in most parts of the world (Hammers 2006).

Ensler is credited with finally opening up a discussion about women's bodies and bringing a humorous side back to feminism (Demarco 2003). TVM has 
already been labeled a 'feminist classic' when it was less than a decade old (Bell and Reverby 2005: 431). It is regarded as 'politically useful for feminists because it utilizes women's experiences of their bodies to provide an avenue for many women to reclaim and learn to love and celebrate their female bodies' (Hall 2005: 102). It may not be great literature, but is fantastic as a performance piece: 'a cabaret floor show by turns hilarious, brassy, lyrical, poignant, charming, romantic, tragic, vulgar, sentimental, raunchy and exhilarating' (Pollitt 2001: 10). Most parts of TVM are 'funny, insightful, and empowering' (ISNA in Hall 2005: 101). Its power comes from its 'transgressive and carnivalesque public stance' (Bell and Reverby 2005: 433). TVM is said to be 'clitically' acclaimed (Demarco 2003). Participants in the productions said they loved TVM and the productions have been well received, with college-age and younger women in general as its major audience. The Monologues often draw 'belly laughs and claps' at just about every piece presented, even when the subject matter is less than pleasant, and win a 'standing ovation' at the end of the show (Swope 2000, McElroy 2000, Tucker 2002, Scott 2003: 407, Bu Wei 2004a, Bell and Reverby 2005: 437).

Inevitably, such a radical feminist work attracts significant criticism and backlash, both lay and scholarly, from inside and outside feminism. ${ }^{4}$ It is charged with promoting lesbianism, sado-masochism, and female masturbation; practising double standards and dishonesty; equating men with 'the enemy' and heterosexual love with violence; giving a blast of hatred at men and heterosexuality; being pro-rape; and unremittingly portraying men as adulterers, abusers, weirdoes, rapists, predators and aggressors, which reveals its vicious anti-male bias (Swope 2000, McElroy 2000, 2002 and 2004). TVM is also accused of materialising the vagina, marginalising intersexed bodies, and reinforcing hetero-patriarchal regulatory norms (Hall 2005: 101). TVM's expression of an ostensibly positive amplification of the vagina as part of a woman's subjectivity is seen as threatening to reduce women to nothing more than their vaginas and vagina-related experiences (Kingston and Norman in Hammers 2006). In addition, with its emphasis on sexuality, TVM is regarded as threatening to over-determine what counts as violence against women (Cooper 2007: 739). What is more, TVM is said to be a 'monologue' controlled from the centre, not a 'dialogue', and thus fails to acknowledge the problems of a global movement that begins with American voice-overs and interpretations of other women's lives (Bell and Reverby 2005: 431, Cooper 2007: 738-739). Consequently, TVM is regarded as a work that 'mobilizes a colonialist discourse' (Hall 2005: 103). All these charges in America represent a force of resistance, which can also happen in other cultures.

Actually, the plural 'monologues' in the title signifies many different voices of women of different ages, sexual orientations, classes, races, and ethnicities speaking out their own (un)happy vagina stories. The monologues, written by an American playwright, are not merely monologues of American women, because they are based on interviews with women from different countries and different cultural backgrounds. Therefore, the monologues are 'not just about one group of women' (Bell and Reverby 2005: 439). Moreover, Ensler adds new stories 
to the production from time to time, mainly according to the annual focus of the international $\mathrm{V}$-day movement, which was the result of her productions of this piece. Thus the work has become an ongoing dynamic project. For example, the story of comfort women of the Second World War and their fight for an apology is included in the 2006 production. Some change resulted from audience complaints. 'Because He Liked to Look at It' was introduced in the $2002 \mathrm{HBO}$ production as a response to audience complaints that there were not enough sketches about vagina-loving heterosexual men. In 2003, men were included in the productions for the first time and were asked to write and perform original ensemble pieces about violence against women from the male perspective (Cooper 2007: 740). In general, women from different parts of the world can find more or less familiar elements in TVM, as women throughout the world sustain more or less the same sexual status and social constraints on their bodies and sexuality. The vitality of TVM lies in its close relationship with women's experiences, which makes it easy to reach out to people worldwide (Bu Wei 2004b). This is an advantage, provided it can overcome the social and institutional constraints and resistance it faces everywhere.

In order to widen its availability, Ensler allows staging for non-commercial purposes and some limited changes to be made to suit local conditions, but its title must remain unchanged. Strict V-Day rules have been made for the groups participating in its college or worldwide campaigns: they must perform specific monologues in a particular order, with no additions, no alterations, no revisions, such as rewording, reorganisation of the monologues, or insertion of more explanatory text into the play itself, even if such changes might arise from the published version, or previous V-Day seasons (Cheng 2004: 327, Bell and Reverby 2005: 432-440, Hall 2005: 112-116, Cooper 2007: 729). Some worry that these restrictions will discourage student and community involvement in the practice of translation and adaptation (Bell and Reverby 2005: 440). Nevertheless, the campus productions in Mainland China, in which local stories are often created and added, have proved that such restrictions hardly work. One reason is that when TVM is performed by different women all over the world, the meanings of the vagina are inevitably transformed in every performance of the play. TVM is actually a point of departure, an invitation to women and girls to create their own stories and find their own voices (Hall 2005: 107). The fluidity, multiplicity, and openness of TVM make it possible for the translators in different parts of the world to supplement or replace with local elements without affecting the ultimate theme and purpose of the source text. The translation by Ai Xiaoming (discussed in Chapters Five, Six, and Seven) is a case in point.

Overall, TVM is a good illustration of how the female body, female sexuality, women's sexual rights, and feminism are closely related to each other. TVM represents a certain strand of Anglo-American feminism. Many of these issues discussed in the play also exist in China, such as domestic violence, rape, sexual abuse or harassment, women's lack of self-awareness and knowledge about pleasure and violence, and unequal power relations between men and women; 
but many would not be openly discussed, such as women's bodies and sexualities and lesbian love. Therefore, the Chinese translations of this play are very good data for analysis to see how Western feminism is received in the Chinese context and whether and how feminist translation strategies are adopted in the Chinese translations.

\subsection{Chinese translations of The Vagina Monologues}

The first Chinese translation of TVM was published in 2000 in Taiwan. Its translator Chen Cangduo (1942-) is a professor of English in National Chengchi University in Taiwan, and also a translator and literary critic. He is said to be a lover of 'erotic literature' and to have a good collection of such books (Chen Guangda 2006). He is the translator of a number of books of erotic literature, such as 爱经 [Kama Sutra], an ancient Sanskrit text giving rules for sensuous and sensual pleasure, love, and marriage in accordance with Hindu law, and 我妹妹与我 [My Sister and I], a book by Friedrich Nietzsche about his affair with his sister. Chen Cangduo is described as 'very diligent in translation' (Zhou Xingxing 2008) and has translated about 200 books since 1968 (Chen Guangda 2006). This means he has translated at least four books a year on average. He declares that he takes translation as a means to help himself read a book in a most intensive and careful way, as well as to obtain remuneration for buying books (Chen Guangda 2006). This way of reading an English book to some extent accounts for his tendency towards a literal translation style, which has attracted much criticism according to my Taiwan colleagues. The Comments by Jiujian may be representative. In comparing the two Chinese translations of On the Road by Chen Cangduo and Wen Chu'an, Jiujian (2006) gives a very severe criticism of the translation by Chen Cangduo:

陈苍多不少奇怪的直译文楚安都意译了过来。[ . . . 陈苍多版本向来是吐口 水的对象, [...] 陈苍多的版本如何叫人愉快地看下去呢? [...]看陈苍多 的版本你是不明白的。 [ . . . 没那个勇气看完陈苍多的译本 [...]。

[The translation by Chen Cangduo is strangely literal in most parts, while that by Wen Chu'an conveys the sense. [. . . T Translations by Chen Cangduo always attract negative comments. [...] How can you enjoy reading his translation? [...] You cannot understand his translation. [...] I have no courage to read through his translation, [...].] (My emphasis)

Why publishers continue to accept and publish his translations given that (some of) his readers express dislike of his translations will not be discussed here as it falls beyond the scope of this study. The limited merit of his translation may be that people can use his translation as a kind of dictionary in order to catch the basic meaning of the source text. What Ai Xiaoming (2003b) did implies this, who gave her students a copy of his translation of TVM to help them understand the text so as to produce their own translation. 
According to Chen Cangduo, ‘翻译像女人, 最好是既忠实又漂亮' [Translation is like a woman, best be both faithful and beautiful] (Chen Guangda 2006). This translational view is more popular among people of his generation. It sounds rather sexist and further indicates that he has a very traditional translation view. It seems an irony that a translator with such an ideology is the translator of a feminist work. His translations, such as his translation of TVM, may appear faithful, but not necessarily beautiful because of his stiff literal translation style. A comparison of Chen's translation with the 1998 edition of TVM shows clearly that his translation matches the 1998 version. In his translation, he adds his own preface. At the end of the translated book, there are two short pieces of introduction, one to the author (Ensler) and the other to the translator.

In 2003, two Chinese translations were produced in Mainland China, both for the stage. One was produced by Yu Rongjun (1971-), an amateur playwright and a manager in the Shanghai Dramatic Arts Centre. When first reading the script in 2001, Yu Rongjun was greatly moved and shocked by the play. After watching the production and the video, he felt that it was a play of great significance. He contacted the agent of the play and was authorised to translate it into Chinese. He finished translating TVM at the end of 2001 and revised it in 2003 for commercial production in Shanghai. The content of his translation shows that his revision absorbed elements from the $2001 \mathrm{~V}$-Day version. His translation contains one 'Vagina fact' (Ensler 2001: 51) and two monologues'Because He Liked to Look at It' and 'My Angry Vagina', present in the 2001 version but absent in the 1998 version. Yu Rongjun must have updated his translation during his revision in 2003, because his translation has two monologues that are not in the 2001 edition: 'Inside Burqua' and 'My Short Skirt'. Moreover, 'Infamous Vagina' in his translation is at least 50 per cent different from the corresponding untitled section in the 1998 and 2001 editions. The difference is not a result of localising or domestication as it still talks about American stories.

In order to make it suitable for the stage, Yu Rongjun made some changes. First of all, he removed the sections that are not necessary or suitable for the stage, such as the forward, acknowledgements, and information about the author and V-Day movement. In Yu's translation, there is one section rewritten and two omitted. The prelude of Yu Rongjun's script is a rewriting of the first part of TVM 'I bet you're worried. ...', a section which constructs an international context by mentioning interviews with women from different countries in spite of its strong American content. Yu Rongjun sticks more to the English source, but adds Chinese ways of referring to the vagina with a hint of humour (see Example 1 in Chapter Five). With the Chinese terms for vagina, Yu Rongjun extends the context of the play to China, making the play less alien to Chinese audiences. One omitted section is the follow-up interview after the monologue 'The Woman who Loved to Make Vaginas Happy'. In the interview, the interviewee gives an erotic description of how she has sex with women, which seems more suitable for reading privately than presenting publicly on the stage (discussed in Chapter Six). The other omitted part is the monologue 'I Was Twelve. My 
Mother Slapped Me', in which some young girls from seven to sixteen talk about their first menses stories. He might think such stories of young girls were less important for a commercial production and thus removed it. Also, he had to trade off what was to be included within normal production time.

Lei Guohua, the director of the production, said that they abridged the original work and dramatised it (Shi Xiaoyan 2010). According to Yu Rongjun, translating this work “更像是又一次创作, 很多地方都采用了诗化的语言来进行 处理, 单纯、严肃, 却更具冲击。' [is more like doing creative writing. Poetic language is used to deal with many parts of the play, simple, serious, but more shocking] (Yu Rongjun in Liu Lifang 2004). Li Shengying, the producer of the Shanghai production, comments that the language of Yu's translation is beautiful. The production keeps close to the source text without dramatic change in order to arouse responses from the society and reduce the distance between Chinese and international feminist discourses (Li Shengying in Liu Lifang 2004). Unfortunately, the production was banned three days before it was due on the stage in the spring of 2004 (Anonymous 2003, Duanmu Zhengyang 2004). Due to the banning, Yu Rongjun's translation ended up as a script on the internet. His translation has been used with adaptation for productions in America and Taiwan, and also for productions in some universities in Mainland China, such as Fudan University in Shanghai (Xiao Pan 2005, Ye Zhou 2005, Anonymous 2005a, Mu Kang 2006).

The other translation was organised by Ai Xiaoming (1953-), a professor in Gender Studies in Sun Yat-sen University in Guangzhou (a port and the third largest city in China). Ai Xiaoming is also a well-known feminist and activist in China, active in safeguarding the rights and interests of women, including anti-(sexual)violence against women. ${ }^{5}$ Unlike many Chinese women writers who are reluctant to be tagged as feminists and would take every opportunity to dissociate themselves from feminism (Lv Pin 2003, Zhang Hongping 2003), she acknowledges that she is a feminist, but does not think that there is much difference between 女性主义 [women's gender-ism/feminine-ism] and 女权 主义 [women's rights-ism/power-ism]. It depends on the circumstances. When facing a male chauvinist, she prefers to use the term '女权' [women's rights/ power]. She believes that the key issues of feminism are rights, resources, and power relationship, and language is a weapon for achieving the aims (Jiang Hua and Dong Jun 2004).

Ai Xiaoming was first attracted to TVM in 2000 when she was in America as a visiting researcher on Women and Gender Studies and witnessed the controversy over TVM there. She found the play successful as it had been put on stage in over 150 universities in North America, and bought a copy, which is very likely to have been the 1998 edition since she was in American in 2000. She appreciated its opposition to violence against women, its positive presentation of how women look at their bodies and their sexual desires (Ai Xiaoming 2004). After she came back to China, Ai Xiaoming (2004) was invited to join the V-Day movement, the worldwide production of TVM. Subsequently, she organised her students to translate the play and put it on stage both for her 
course and the V-Day movement. For this event, Ai Xiaoming obtained the video of the English production at Harvard University, and made her students note down and type the script separately so that each student had an e-version of it. The script helped the students understand the play when they watched the video recording (Ai Xiaoming 2003b). This means the Harvard production is not identical to the 1998 edition; otherwise it would be unnecessary for the students to note down the script of the Harvard production. She also bought a copy of Chen Cangduo's translation to help the students understand the script in their preparation for class discussion. ${ }^{6}$ Compared with the 1998 and 2001 English versions, the translation seems an adaptation based on more than one single version. The translation contains the monologue called 'Because He Liked to Look at It', which is added in the 2001 English version but absent in the 1998 version. The translation also contains the part called 'My Short Skirt', which is not included in either the 1998 or the 2001 version. Therefore, it is likely that the translation is based on at least three sources: the 1998 version, the 2001 version, and the Harvard production, as is Yu's translation.

Like Yu Rongjun, Ai Xiaoming also removes the sections that are not necessary or suitable for the stage, such as the forward and acknowledgements, but she keeps the information about the author and V-Day movement, which is turned into a condensed introduction placed after the translation. Because people in different cultures face different problems, she does not simply present foreign stories that seem irrelevant to Chinese life, but tries to make the piece sound like Chinese people telling Chinese stories. The prelude of Ai's translation reflects such efforts, which is a combination of the first part of TVM 'I bet you're worried. ...' and the 'Introduction' in the 1998 English version (Ensler 1998: $\mathrm{xix}-\mathrm{xxv}$ ). She rewrites to fit the student translation and to shift the American context into the Chinese student context (discussed in Chapter Five). After the classroom discussion of TVM, Ai Xiaoming felt that the discussion lacked a local dimension, i.e. 'ourselves, our local vagina culture and experiences' (Ai Xiaoming 2003b). Therefore, in her translation, some local stories were created and added, such as 'Dry River', and some monologues were localised or domesticated, such as 'Menarche' and 'Moaning' (discussed in Chapters Five and Six). She also omits the follow-up interview with the woman who loved to make vaginas happy (discussed in Chapter Six). She adds numerous stage directions to explain the meaning of the play and how to perform the play, which is one of the major features of her translation (discussed in Chapters Five and Six).

Ai Xiaoming successfully translated the script into a production. Her script does not look completely identical to her production, For example, there is '弃婴' [Deserted Female Babies] in the production but not in the script. This story comes from a startling news report about twenty-eight female babies found by the police in a bus. They were packed in threes in travel bags. The oldest was no more than three months old. One had already died. Like 'My grandma said, if you wash your hair during your period, you will not give birth to a son' (see 'Menarche' discussed in Chapter Five), this added story exposes the oppression Chinese women have long suffered, and denounces the evil of traditional 
concepts of '男尊女卑, 重男轻女' [men are superior to women] and '多子 多福' [the more sons, the more happiness]. Such concepts still prevail in many areas. As a result, female babies are more prone to discrimination, desertion, being sold or even killed. Some foetuses may even be reduced to stewed tonic (Cao Shuying 2007, Xiao Hui 2009). ${ }^{7}$ Such localising or domestication brings the play closer to Chinese audiences, and makes the piece work better in the Chinese context.

As a professor, Ai Xiaoming organised the translation and production as part of her course. As a feminist, she intends to raise awareness of sexual violence and change the society through putting the play on stage. To her, drama is also an instrument of education. It attracts attention and allows experiences to be shared. The power of TVM lies in its talking about women's own stories and disclosing ignored women's experiences (He Liangzi 2004). She gave her production a subtitle: 'Re-imagine Women's Body' to foreground the central motif of the production, because an important part of TVM is to imagine women's sexual experiences, which have been fragmented, twisted, and falsified in men's interpretation. In China, women are often said to have been quite liberated. In Ai Xiaoming's view, this implies that whether women are liberated or not is a matter to be judged by men, not by women. When it is judged by women, it is often regarded as one-sided, subjective and personal. It is a prejudice against women. The production is an initiation to talk about women's experiences by women themselves. The aim is to achieve equality and mutual understanding between women and men (Zhang Qi and Pang Minghui 2004). Such a subtitle is first of all a call for women to draw attention to their own bodies. Only when a woman knows her body and understands it, can she care, value and protect it. It is also a call for men to listen to women's stories so as to understand and respect women's bodies and sexuality. Hence, Ai's translation and production play a didactic role.

Her production is the first Chinese production in Mainland China. She made a documentary ‘阴道独白: 幕后故事” [The Vagina Monologues: Stories Behind the Scenes], which recorded the process of their efforts on the production. As part of the global V-Day movement to stop violence against women, she distributed the DVD to many universities, colleges and schools in Mainland China as well as in Hong Kong. In particular, she distributed it to all the centres of gender and women studies in universities and called on people to watch and discuss the play. The DVD has been played not only in universities in developed areas such as Guangdong, Shanghai, and Beijing, but also in relatively backward areas such as Hunan, Hebei, and Guizhou. Not only university students, but also workers, peasants and migrant workers have watched the production ( $\mathrm{Ai}$ Xiaoming 2004, Liang Huimin 2007, Xiao Hui 2009: 66). Her production is the most influential one in China.

Among the three translations, only the translation by Chen Cangduo was published in book form, while the other two are posted and available on the internet. On the whole, there are more omissions, additions and adaptations in Ai's translation than in Yu's translation. The reasons for the omissions, additions 
and adaptations are co-related. Some changes result from language and cultural differences, some from form and time restriction for a production, and some from (self-)censorship. For example, more additions in Ai's translation account for more deletions in view of the time limit for a production. In general, the translation by Ai Xiaoming is longer than that by Yu Rongjun, perhaps due to their different aims: the former is for a student production and the latter for a commercial production. As a professor who closely works with young students, Ai Xiaoming pays great attention to educating students. She believes that students are the future of the society: they will work in some important organisations, they will be decision-makers, and they will be important participants in social activities (Ai Xiaoming 2004). The influence of these translations can be identified to a degree from student productions in the Chinese context, because these three translations, particularly the translations by Ai Xiaoming and Yu Rongjun, are the major sources or references for student productions. However, when the translations are used for productions in different places, they are all more or less revised, adapted, localised, and supplemented with other (local) stories to suit the appreciation and experiences of local audiences. Therefore, there are actually many more Chinese adaptations of the play. However, these adaptations are mostly not available, except for some brief reports. For example, on the internet, only a few parts of the adaptation by Zhejiang University can be found. As a result, in this study, the focus is on these first three major translations.

\section{Notes}

1 Beauvoir does accept some of what she terms masculine values, but not all of them (Simons 1999: 83).

2 This can reasonably be explained in plain ideological terms - in Taiwan, anything to do with communism or Marxism would be held with suspicion. The translators (or editors), especially in 1986, might feel it safer to transliterate rather than to use a term well known and used in Mainland China. This could be an instance of self-censorship (due to political reasons) at work.

3 In the market-oriented translation publishing industry, many 'new' translations have been produced through 'cut and paste' in order to gain quick profit (Li Jingrui 2008, see Chapter Seven for more discussion).

4 There is a wealth of popular commentary, but scholarly discourse has not yet taken up a thorough treatment of TVM (Hammers 2006: 221). Many feminist (and other) researchers have found researching 'taboo', 'private' or 'sensitive' topics problematic (Braun 1999: 367). This is even more so in China. This partly contributes to the limited treatment of TVM by researchers.

5 A famous example is that Ai Xiaoming was involved in the case of Huang Jing in 2003. See www.iciba.com/\%E9\%BB\%84\%E9\%9D\%99\%E6\%Al\%88/ for a brief account of the case. Ai Xiaoming said, as a researcher in women studies, she could not keep silent when seeing a woman being violated (Jiang Hua and Dong Jun 2004).

6 See Guo Jia and Huang Haitao (2002), Chen Yu et al. (2002), Luo Fan et al. (2002), Chen Cuiping et al. (2002), Chang Bin et al. (2002), Dong Yan et al. (2002), and Gao Hong and Yang Yuan (2002) for information about their discussion of TVM.

7 Some people believe that eating foetuses can keep one young. Dumplings, a 2004 Hong Kong horror movie, directed by Fruit Chan (also Chen Guo), exemplifies this (Chan 2004). 


\section{Bibliography}

Ai, Xiaoming 艾小明 (trans.) (2003a) 阴道独白 [The Vagina Monologues], http://smileinwind. bokee.com/2440712.html (last accessed on 31 March 2006).

— (2003b) ‘《阴道独白》与对话教学小结’ [The Vagina Monologues and Dialogue: A Brief Teaching Summary], http://genders.zsu.edu.cn/board/viewpoint/display.asp?id=31 (last accessed on 1 April 2006).

- (2004) ‘全球女性主义口述史访谈’ [An Interview on Global Feminist Oral History], www.umich.edu/ glblfem/en/transcripts/china/aixiaomingm.pdf (last accessed on 22 February 2008).

Anonymous (2003) ‘美国当代经典名剧《阴道独白》开排” [Contemporary American Classic Drama The Vagina Monologues is in Rehearsal], http://drama.anhuinews.com/ system/2003/12/26/000526821.shtml (last accessed on 22 February 2008).

— (2005) ‘专访《阴道独白》导演蓝贝芝’ [A Special Interview with Lan Beizhi, Director of The Vagina Monologues], http://bloguide.ettoday.com/mathink/textview.php?file=9836 (last accessed on 4 July 2008).

- (2008) '中国改革开放30年引进版畅销书甄析——兼观三十年外来文化引进与中国 人心灵成长历程' [The Examination of Translated Bestsellers in Three Decades of Reform and Opening Up in China: How did Western Culture and Translated Bestsellers Change Chinese People's Thoughts], 中国图书商报 [China Book Business Report], www.cbbr.com.cn/infol85061.htm (last accessed on 15 February 2010).

Bair, Deirdre (1990) Simone de Beauvoir: A Biography, New York: Summit.

Bauer, Nancy (2011) 'Simone de Beauvoir: The Second Sex', Notre Dame Philosophical Reviews, http://ndpr.nd.edu/news/25488-the-second-sex/ (last accessed on 28 August 2011).

Beauvoir, Simone de (1975) Force of Circumstance, translated by Richard Howard, Harmondsworth: Penguin. The French original was first published in Paris by Librairie Gallimard in 1963.

_ (1972) The Second Sex, translated and edited by H. M. Parshley, Harmondsworth: Penguin.

_ (1993) The Second Sex, translated and edited by H. M. Parshley, New York: Knopf.

Bell, Susan E. and Susan M. Reverby (2005) 'Vagina Politics: Tensions and Possibilities in The Vagina Monologues', Women's Studies International Forum 28: 430-444.

Bogic, Anna (2009) 'Translating the Philosophy of Simonde de Beauvoir: The Case of Le Deuxième Sexe', Candian Association for Translation Studies Bulletin/Newsletter 1 January 2009, 4.

— (2011) 'Why Philosophy Went Missing: Understanding the English Version of Simone de Beauvoir's Le deuxième sexe', in Luise von Flotow (ed.) Translating Women, Ottawa: University of Ottawa Press, 151-167.

Braun, Virginia (1999) 'Breaking a Taboo? Talking (and Laughing) about the Vagina', Feminism \& Psychology 9(3): 367-372.

Braun, Virginia and Eve Ensler (1999) 'Virginia Braun in Conversation with Eve Ensler: Public Talk about "Private Parts", Feminism \& Psychology 9(4): 515-522.

$\mathrm{Bu}, \mathrm{Wei}$ 卜卫 (2004a) “阴道——这个词让你微笑, 它让你骄傲, 它让你成为你自己' [Vagina-This Word Makes You Smile, Proud and Become Yourself], http://cyc6. cycnet.com:8090/othermis/stopdv/content.jsp?id=9023 (last accessed on 6 July 2008).

— (2004b) '从上海到全国' [From Shanghai to the Whole China], http://cyc6.cycnet. com:8090/othermis/stopdv/content.jsp?id=9024\&scode=0201020101 (last accessed on 6 July 2008). 
Cao, Shuying 曹疏影 (2007) “阴道的复数“独白”一一记《阴道独白》在中国, [Plural 'Monologue' of Vagina: The Vagina Monologues in China], http://genders.zsu.edu.cn/ News/1768-Content-1768.html (last accessed on 7 June 2010).

Chan, Fruit 陈果 (dir.) (2004) 饺子 [Dumplings], Film 4 broadcast.

Chang, Bin 常涁, Zhu Kunling 朱坤领, and Peng Qiwen 彭绮文 (2002) '战争强暴中, 女人失去了什么?' [Rape in War, What Have Women Lost?], http://genders.zsu.edu. $\mathrm{cn} /$ board/viewpoint/display.asp?id=28 (last accessed on 26 July 2008).

Chen, Cangduo 陈苍多 (trans.) (2000) 阴道独语 [The Vagina Monologues], Taibei: 新雨出版社 [Xinyu Publishing House].

Chen, Cuiping 陈翠平, Chen Xia 陈霞, Tang Hongmei 唐红梅, and Ke Qainting 柯倩婷 (2002) '女性笑声的革命性力量一一分析《热衷让阴道快乐的女人》' [The Revolutionary Power of Women's Laughter: An Analysis of 'The Woman who Loved to Make Vaginas Happy'], http://genders.zsu.edu.cn/board/viewpoint/display.asp?id=27 (last accessed on 26 July 2008).

Chen, Guangda 陈光达 (2006) ‘陈苍多:书瘾病历图’ [Chen Cangduo: A Map of his Book-addiction], 书摘 [Digest], 11, http://qkzz.net/Announce/announce.asp? BoardID= $19300 \& I D=495072$ (last accessed on 28 July 2008).

Chen, Huan 陈欢 (2004) ““正本清源”女性“圣经”' [Tracing the Women’s Bible Back to its Origin], 中华读书报 [China Reading Weekly], 4 August 2004, http://www.gmw. cn/01ds/2004-08/04/content71928.htm [last accessed on 16 May 2009].

Chen, Tao 陈涛 (2012) ‘郑克鲁: 民意说哪个译本好, 就差不到哪里去' [Zheng Kelu: The Translation Cannot be Bad if Readers Say it is Good]. 中国新闻周刊 [China Newsweek], 24 December 2012, ‘文学' [Literature].

Chen, Xiaoli 陈肖利 (2009) ‘波伏娃《第二性》对中国女性主义的启蒙’ [The Enlightenment from Beauvoir's The Second Sex to Chinese Feminism], Journal of China Women's University 6: 48-52.

Chen, Yu 陈瑜, Chen Jingmei 陈静梅 and Yi Yumei 易玉梅 (2002) ‘肯定身体, 肯定自我 ——谈《阴道独白》剧“阴毛”一幕' [Love our Bodies, Love Ourselves: On 'Hair' in The Vagina Monologues], http://genders.zsu.edu.cn/board/viewpoint/display.asp?id=25 (last accessed on 26 July 2008).

Cheng, Sea Ling (2004) 'Vagina Dialogues?', International Feminist Journal of Politics 6(2): 326-334.

Cooper, Christine M. (2007) 'Worrying about Vaginas: Feminism and Eve Ensler's The Vagina Monologues', Signs 32(3): 727-758.

Dai, Jinhua 戴锦华 (2007) ‘岁月留痕’ [Time Leaves Traces], 书屋 [Book Room] 10: 36-41.

Demarco, Marisa (2003) 'Dare You to Say "Vagina": Eve Ensler's Acclaimed "Vagina Monologues" Swing by Santa Fe This Week', Culture, http://media.www.dailylobo. $\mathrm{com} / \mathrm{media} /$ storage/paper344/news/2003/02/06/Culture/Dare-You.To.Say. vagina-362294.shtml (last accessed on 11 August 2008).

Dong, Yan 董艳, Liang Jiamin 梁嘉敏, and Lu Tianyu 卢天玉 (2002) '儿童的阴道 独白' [Children's Vagina Monologues], http://genders.zsu.edu.cn/board/viewpoint/ display.asp?id=29 (last accessed on 26 July 2008).

Duanmu, Zhengyang 端木正阳 (2004) ‘女性的秘密花园会说话’ [Woman’s Secret Garden Can Speak], http://qkzz.net/article/3aaf3f9b-2039-4547-aee6-a7353d7e8a57.htm (last accessed on 7 June 2010).

Ensler, Eve (1998) The Vagina Monologues, New York: Villard.

— (2001) The Vagina Monologues: The V-Day Edition, New York: Villard. 
Evans, Ruth (1998) 'Introduction: The Second Sex and the Postmodern', in Ruth Evans (ed.) Simone de Beauvoir's The Second Sex: New Interdisciplinary Essays, Manchester: Manchester University Press, 1-30.

Fallaize, Elizabeth (2002) 'Le destin de la femme an foyer: Tradiure "la femme mariée» de Simone de Beauvoir', in Christine Delphy, Sylvie Chaperon, Kate Fullbrook and Edward Fullbrook (eds.) Cinquantenaire du Deuxieme Sexe, Paris: Syllepse.

Flotow, Luise von (1997) Translation and Gender: Translating in the 'Era of Feminism', Manchester: St Jerome.

Fullbrook, Edward and Kate Fullbrook (1998) Simone de Beauvoir: A Critical Introduction, Oxford: Polity Press in association with Blackwell Publishers.

Gao, Hong 高泓 and Yang Yuan 杨媛 (2002) ‘重新想象身体的方式——阴道之美’ [Ways of Reimagining the Body: The Beauty of the Vagina], http://genders.zsu.edu.cn/ board/viewpoint/display.asp?id=30 (last accessed on 26 July 2008).

Gillman, Richard (1988) 'The Man Behind the Feminist Bible', The New York Times, 22 May 1988, Book Review.

Guo, Jia 国佳 and Huang Haitao 黄海涛 (2002) '导言: 我们为什么要讨论《阴道独白》' [Introduction: Why should We Discuss The Vagina Monologues], http://genders.zsu. edu.cn/board/viewpoint/display.asp?id=24 (last accessed on 26 July 2008).

Hall, Kim Q. (2005) 'Queerness, Disability, and The Vagina Monologues', Hypatia 20(1): 99-119.

Hammers, Michele L. (2006) 'Talking About "Down There": The Politics of Publicizing the Female Body through The Vagina Monologues', Women's Studies in Communication 29(2): 220-243.

He, Liangzi 何亮子 (2004) “《阴道独白》幕后女人帮” [The Women behind The Vagina Monologues], 潇酒 [Chic], January 2014, http://genders.sysu.edu.cn/News/835Content-835.html (last accessed on 6 July 2008).

Jiang, Hua 江华 and Dong Jun 董珺 (2004) ‘艾小明: 我大概勉强可以归为女人’ [Ai Xiaoming: I May be Categorised as a Woman with Bad Grace], 人物周刊 [VIP Weekly], www.nanfangdaily.com.cn/nfrwzk/20041103/gg/200411220019.asp (last accessed on 4 July 2008).

Jiujian 九间 (2006) “《在路上》两个中文译本片段比较 [On the Road: A Comparison of a Segment of its Two Chinese Translations]', http://smalloranges.ycool.com/ post.1247685.html (last accessed on 28 July 2008).

Keefe, Terry (1983) Simone de Beauvoir: A Study of Her Writings, London: Harrap.

_ (1994) 'Another "Silencing of Beauvoir"? Guess What's Missing This Time', French Studies Bulletin 50: 18-20.

Kruks, Sonia (1998) 'Beauvoir: The Weight of Situation', in Elizabeth Fallaize (ed.) Simone de Beauvoir: A Critical Reader, London and New York: Routledge, 43-71.

Lennon, Kathleen (2010) 'Feminist Perspectives on the Body', in Edward N. Zalta (ed.) The Stanford Encyclopaedia of Philosophy, http://plato.stanford.edu/archives/fall2010/ entries/feminist-body/ (last accessed on October 18, 2011).

$\mathrm{Li}$, Jingrui 李景端 (2008) ‘引进版图书现状浅析 [The Status Quo of Imported Books]', 中华读书报 [China Reading Weekly], 18 January 2008, www.cbi.gov.cn/wisework/ content/14067.html (last accessed on 16 March 2010).

Li, Qiang 李强 (trans.) (2004) 第二性 [The Second Sex], Beijing: 西苑出版社 [Xiyuan Publishing House].

Liang, Huimin 梁惠敏 (2007) ‘专访《阴道独白》两位年轻搞手一人生中必要做的事” [A Special Interview with Two Young Producers of The Vagina Monologues: A Must 
in One's Life], 女流 [Women] 45: 22-25, www.womenresources.org/archives/1253 (last accessed on 4 July 2008).

Liu, Kunya 刘琨亚 (2009) “波伏瓦《第二性》出版60年: “她”不在萨特身后” [The 60th Anniversary of the Publication of The Second Sex: 'She' is not Behind Sartre], 深圳 晚报, [Shenzhen Evening News], 14 April 2009, http://book.sina.com.cn/news/v/ 2009-04-14/1139253998.shtml (last accessed on 16 May 2009).

Liu, Lifang 刘莉芳 (2004) ““V”的呐喊: 亚洲首个专业剧团排演《阴道独白》’ [A Whoop by V: The First Asian Professional Troupe Rehearsing The Vagina Monologues], 外滩 画报 [The Bund], http://news.sina.com.cn/s/2004-01-13/08442616843.shtml (last accessed on 22 February 2008).

Luo, Fan 罗璠, Hu Kejian 胡克俭, and Zhao Huifang 赵慧芳 (2002) ‘破除迷思, 寻找 阴蒂' [Break the Myths, Look for Clitoris], http://genders.zsu.edu.cn/board/viewpoint/ display.asp?id=26 (last accessed on 26 July 2008).

Lv, Pin 吕频 (2003) ‘被负面化的女性主义者及其他’ [Demonised Feminists and Other Issues]. 中国妇女报 [China Woman], 18 February 2003, ‘女性与社会' [Women and Society].

McElroy, Wendy (2000) 'The "Monologues” Ride Again', www.lewrockwell.com/mcelroy/ mcelroy 19.html (last accessed on 10 August 2008).

_ (2002) 'Take Back Valentine's Day!' www.ifeminists.com/introduction/editorials/ 2002/0212.html (last accessed on 10 August 2008).

_ (2004) 'A Not Very Funny Valentine', www.canadiancrc.com/NewspaperArticles/ FoxNotFunnyValentine27JAN04.asp (last accessed on 11 August 2008).

Moi, Toril (2002) 'While We Wait: The English Translation of The Second Sex', Signs 27(4): 1005-1035.

- (2008) 'It Changed my Life!', The Guardian, 12 January 2008.

- (2010) 'The Adulteress Wife', London Review of Books 32(3): 3-6. www.lrb.co.uk/ v32/n03/toril-moi/the-adulteress-wife (last accessed on 16 February 2010).

$\mathrm{Mu}$, Kang 慕康 (2006) ‘附表一: 上海部分高校剧社情况调查表' [Appendix I: Drama Societies in Universities and Colleges in Shanghai], www.wxnyjs.net/bbs/dispbbs.asp ?BoardID=8\&replyID=12384\&ID=2586\&skin=1 (last accessed on 6 July 2008).

Mussett, Shannon (2010) 'Simone de Beauvoir (1908-1986)', Internet Encyclopedia of Philosophy, www.iep.utm.edu/beauvoir/ (last accessed on 18 October 2011).

Okely, Judith (1998) 'Reading The Second Sex', in Elizabeth Fallaize (ed.) Simone de Beauvoir: A Critical Reader, London and New York: Routledge, 19-28.

Parker, Emily Anne (2011) 'A Second Look at The Second Sex', www.philosophynow.org/ issue82/The_Second_Sex_by_Simone_de_Beauvoir (last accessed on 8 October 2011).

Patterson, Yolanda Astarita (1992) 'Who was this H. M. Parshley?: The Saga of Translating Simone de Beauvoir's The Second Sex', Simone de Beauvoir Studies 9: 41-47.

Pilardi, Jo-Ann (1995) 'Feminists Read The Second Sex', in Margaret A. Simons (ed.) Feminist Interpretations of Simone de Beauvoir, University Park, PA: Pennsylvania State University Press, 29-43.

Pollitt, Katha (2001) 'Vagina Politics (Review)', The Nation 272(9): 10.

Sang, Zhuying 桑竹影 and Nan Shan 南珊 (trans.) (1986) 第二性一女人 [ The Second Sex-Women], Changsha: 湖南文艺出版社 [Hunan Literature \& Art Publishing House].

Scott, Shelly (2003) 'Been There, Done That: Paving the Way for The Vagina Monologues', Modern Drama 46(3): 404-423.

Shen, Ke 沈珂 and Xu Jun 许钧 (2009) ‘《第二性》在中国的译介历程” [The Introduction and Translation of The Second Sex in China], 江海学刊 [Jianghai Academic Journal] 4: 199-206. 
Shi, Xiaoyan 史小岩 (2010) ‘说说女人的那些事《阴道独白》6月再来深 [Talking About Women's Things, The Vagina Monologues Will Come Again to Shenzhen in June]', 深圳晚报 [Shenzhen Evening Post] B8, 27 May 2010, http://wb.sznews. com/html/ 2010-05/27/content1089621.htm (last accessed on 7 June 2010).

Shu, Xiaofei 舒小菲 (trans.) (2009) 第二性 [The Second Sex], Beijing: 西苑出版社 [Xiyuan Publishing House].

Simons, Margaret A. (1982/1999) 'Beauvoir Interview', in Margaret A. Simons, Beauvoir and The Second Sex: Feminism, Race, and the Origins of Extentialism, Lanham, MD: Rowman \& Littlefield Publishers, 55-59.

_ (1983) 'The Silencing of Simone de Beauvoir: Guess What's Missing from The Second Sex', Women's Studies International Forum 6(5): 559-564.

— $(1985 / 1999)$ 'Beauvoir Interview', in Margaret A. Simons, Beauvoir and The Second Sex: Feminism, Race, and the Origins of Extentialism, Lanham, MD: Rowman \& Littlefield Publishers, 93-100.

— (1995) Feminist Interpretations of Simone de Beauvoir, University Park, PA: Pennsylvania State University Press.

- (1998) 'Is The Second Sex Beauvoir's Application of Sartrean Existentialism?', Philosophy and Gender (A collection of papers given at the Twentieth World Congress of Philosophy, in Boston, Massachusetts from 10-15 August 1998), www.bu.edu/ wcp/Papers/Gend/GendSimo.htm (last accessed on 28 August 2011).

_ (1999) Beauvoir and The Second Sex: Feminism, Race, and the Origins of Extentialism, Lanham, MD: Rowman \& Littlefield Publishers.

- (ed.) (2006) Philosophy of Simone de Beauvoir: Critical Essays, Bloomington, IN: Indiana University Press.

Swope, Robert (2000) 'Applauding Rape at Georgetown', www.academia.org/ campusreports/2000/may20004.html (last accessed on 10 August 2008).

Tang, Yi 唐译 (trans.) (2009) 第二性女人 [The Second Sex Woman], Beijing: 北京燕山 出版社 [Beijing Yanshan Press].

Tao, Tiezhu 陶铁柱 (trans.) (1998) 第二性（全译本) [The Second Sex (Complete Translation)], Beijing: 中国书籍出版社 [China Books Publishing House].

Tucker, Charlotte (2002) 'V-Day Filled with Moans, Screams: Vagina Monologues Draws Hundreds to David Lawrence', http://media.www.pittnews.com/media/storage/ paper879/news/2002/02/15/News/VDay-Filled.With.Moans.Screams-1795031.shtml (last accessed on 11 August 2008).

Vazquez, Olga Castro (2008) '(Para)Translated Ideologies in Simone de Beauvoir's Le Deuxième Sexe: The (Para)Translator's Role', in Teresa Seruya and Maria Lin Moniz (eds) Translation and Censorship in Different Times and Landscapes, Newcastle, UK: Cambridge Scholars Publishing, 130-146.

Vintges, Karen (1996) Philosophy as Passion: The Thinking of Simone de Beauvoir, translated by Anne Lavelle, Bloomington and Indianapolis: Indiana University Press.

Wang, Youqin 王友琴 and Qiu Xichun 邱希淳, et al. (trans.) (1988) 女人是什么 [ What is Woman], Beijing: 中国文联出版公司 [China Federation of Literary and Art Circles Publishing Corporation].

Xiao, Hui 肖慧 (2009) “《阴道独白》的跨国旅行” [Transnational Voyage of The Vagina Monologues], 妇女研究论丛 [Collection of Women's Studies] 2, http://qkzz.net/article/ 8ad0ae2e-736c-45a9-b5al-d007c6602c4e.htm (last accessed on 7 June 2009).

Xiao, Pan 小潘 (2005) '记《阴道独白》的演员们' [On the Actresses of The Vagina Monologues], www.redphoenixusa.com/ShowThread.aspx? PostID=11760 (last accessed on 22 February 2008). 


\section{Contextualising the Chinese translations}

Xiao, Yi 晓宜 and Zhang Yali 张亚莉, et al. (trans.) (1988) 女性的秘密 [Female Secrets], Beijing: 中国国际广播出版社 [China International Radio Press].

Ye, Zhou 叶舟 (2005) “最大胆的“独白”' [The Boldest Monologues] www.yrdrama.org/ vm/vmlining l.htm (last accessed on 22 February 2008).

Yu, Rongjun 喻荣军 (trans.) (2003) 阴道独白 [The Vagina Monologues], http://bbs. sachina.pku.edu.cn/archiver/tid-3681.html (last accessed on 27 December 2006).

Zhang, Hongping 张红萍 (2003) '女性主义者怎么了?' [What Happens to Feminists?], 中国妇女报 [China Woman], 11 February 2003, ‘两性论坛' [Gender Forum].

Zhang, Qi 张祺 and Pang Minghui 庞明慧 (2004) “从“V”的独白到阴道独白” [From "V" Monologues to The Vagina Monologues], http://genders.sysu.edu.cn/News/840Content-840.html (last accessed on 6 July 2008).

Zheng, Kelu 郑克鲁 (2011)《第二性》[The Second Sex]. Shanghai: 上海译文出版社 [Shanghai Translation Publishing House].

- (2012) '你看过《第二性》吗?' [Have You Ever Read The Second Sex?]. 文艺报 [Journal of Literature and Art], 21 December 2012, '世界文坛' [World Literature].

Zhou, Xingxing 周星星 (2008) ‘从台北到布鲁塞尔: 谈出版' [From Taibei to Brussels: On Publication], http://blog.chinatimes.com/jostar2/jostar2/archive/2008/07/15/ 298873.html (last accessed on 28 July 2008). 


\section{Translating the female body and female sexuality in The Second Sex}

Beauvoir believes that 'the intimate, the affective, and the sexual' are 'at the heart of lived experience, the center of philosophical enquiry, and the core of the human condition'; therefore, sexuality is 'inextricable from politics' and 'the way to change other people's politics [is] to write about one's own emotional life' (Hawthorne 2000: 5). Beauvoir is regarded as the first thinker in France explicitly to politicise sexuality, seeking to 'assail and destroy patriarchal myths of femininity' in The Second Sex (TSS) (Moi in Hawthorne 2000: 7), which greatly influenced the 'sexual revolution' in the 1960s (Hawthorne 2000: 5 ). In Book II, Beauvoir discusses the formation of women, in which the female body and eroticism are essential and extensively dealt with, especially in such chapters as 'Childhood', 'The Young Girl', 'Sexual Initiation', 'Lesbianism', 'The Married Woman', 'The Mother', and 'From Maturity to Old Age'. This is said to have given the book a 'strongly sexual' nature. Some critics have noted that too much attention has been paid to the sexual content rather than to the philosophical merit of her work (Fallaize 1998: 8). For instance, Millett complains that it is 'a very disturbing book' due to the sexual content (in Forster and Sutton 1989: 20). Mauriac claims that the book has made him entirely familiar with Beauvoir's vagina (Beauvoir 1975: 197). It is even regarded as 'the best manual of instruction on making love' available in English (Bair 1990: 439), which was the major motivation of the publisher to bring out an English translation of it. Therefore, although the English translation omits references to cultural taboos and the tedium of women's daily lives (Flotow 1997: 50), the passages on the female body and female sexuality remain almost intact as they are the selling points for the publisher.

How the Chinese translators deal with the material of the female body and female sexuality is of significance in respect of transmitting feminism. In this chapter, I compare the 1986, 1988, 1998, and 2004 Chinese translations that all contain Book II, and discuss the translation strategies from feminist perspective. It is a comparison between the translations by six female translators and those by two male translators. The 1986 translation is conducted by two female translators (Sang Zhuying and Nan Shan). The 1988 translation is co-worked by three female translators (Wang Youqin, Ding Wenjuan and Yu Yingchun) and one male translator (Qiu Xichun). Since three of the four translators are 


\section{The female body and female sexuality in TSS}

female and the first and female translator is presumably responsible for the $\mathrm{co}^{-}$ ordination of the whole translation, and since the male translator Qiu Xichun is responsible for only two sections (Part IV, sections 1 and 3, pp. 24-105 and 166-208), in this discussion, the 1988 translation is taken as a translation by female translators, with Qiu Xinchun considered as an 'honorary female'. The 1998 and 2004 translations are produced by male translators. Here the gender identities of the translators are established on the basis of the femininity and masculinity of the names and Chinese naming practice, except that of Tao Tiezhu. ${ }^{1}$ In his translator's preface, Tao Tiezhu made his gender identity clear in thanking his wife for her help in proofreading his translation and pointing out some language problems, such as '语言生涩和不准确的地方' [jerky and inaccurate language] (1998: 6). No information about the other translators has been found. The comparison consists of sixteen selected short passages that describe the female body and female sexuality. Female sexuality here refers to heterosexuality only. Lesbian sexuality is discussed separately in Chapter Six. In these selected passages, twenty-four cases of different translations relevant to gender and feminism are discussed.

\subsection{Translating the female body}

In TSS, Beauvoir discusses the development and changes of the female body from childhood to old age which often result in confusion, shame, depression or pride in women in different ages because 'women imagine themselves in response to being imagined' (Felstiner 1980: 250). This is similar to what Butler says that the body is never a natural phenomenon since it is entrenched in a specific cultural language (1986: 45-46). Bartky also points out that '[i]n contemporary patriarchal culture, a panoptical, male connoisseur resides within the consciousness of most women: They stand perpetually before his gaze and under his judgment.' As a result, it is common to see that in the regime of institutionalised heterosexuality, 'woman lives her body as seen by another' (Bartky 1997: 140). Many women tend to be critical of their appearance and sensitive to the changes of their bodies. Changes to female breasts and buttocks especially show the changes to the female body with age, which often bring about psychological or emotional fluctuation, as shown in the following examples.

\subsubsection{Women's physical appearance}

Examples 1 to 4 describe women's physical appearance at different ages. Example 1 comes from 'Childhood', Examples 2 to 3 from 'Sexual Initiation', and Example 4 from 'The Mother'. In the abridged translation by Li Qiang, a large proportion of descriptions, analysis and illustrations of women's life experience is cut. Examples 2 to 4 (and 6 to 8 ) fall in these cuts and are absent in Li's translation. 
I ST: Arms, legs, skins, muscles, even the rounded bottom on which she sits - up to now all these have had their obvious usefulness; only her sex, clearly a urinary organ, has seemed to be somewhat dubious, but secret and invisible to others. Under her sweater or blouse her breasts make their display, [. . . ]. (324)

$\mathrm{S} / \mathrm{N}$ : 四肢、皮肤、筋肉, 甚至那圆润起来的臀部一一这一切, 到目前 为止, 一直有着它们的用处。性器官除了解尿之外, 用处有点可 疑, 但隐秘不露在外。在她的毛衣或祄衫之下, 她的双乳却显露 出来。(66)

[The four limbs, skins, muscles, even the rounded and smooth bottom-all these, up to now, have had their usefulness; the sexual organ, except for urination, is of dubious use, but secret and not exposed to the outside. Under her sweater or blouse, her breasts become visible.]

$\mathrm{W} / \mathrm{Q}$ : 四肢、皮肤、肌肉, 甚至那圆润起来的臀部——这一切, 到目前 为止, 一直有着显而易见的用处。性器官除了能尿之外, 用处有点 可疑, 但它隐秘不露在外。在她的毛衣或衬衫下面, 双乳却显露 出来。(78)

[The four limbs, skins, muscles, even the rounded and smooth bottom-all these, up to now, have had their obvious usefulness; the sexual organ, except for urination, is of dubious use, but secret and not exposed to the outside. Under her sweater or blouse, her breasts become visible.]

Tao: 胳臂、腿、皮肤、肌肉, 甚至还有那丰满的臀部一一至今这一切 都显然有各自的用处。只有她的性器官, 除了无疑是用来撒尿 的, 作用还有点暧昧, 但它是隐秘的, 别人看不见。罩在毛衣或 外衣下面的乳房, 却在炫耀自己, [...]。(355)

[Arms, legs, skins, muscles, even the plump bottom-up to now all these have had their obvious usefulness; only her sexual organ, except that it is undoubtedly for urination, has dubious function, but it is secret, and others cannot see it. Under her sweater or garment, her breasts are showing off themselves, [...].]

$\mathrm{Li}$ : 手臂、大腿、皮肤、肌肉, 甚至于那丰满的臀部——此时这些还 明显有自身的用处。惟独她的性器官, 排泄无疑是一个用处, 其 他的作用还有些暧昧, 但它是隐藏的秘密, 别人无法看到。而在 毛衣或外衣之下的乳房, 却在炫耀着自己, [...]。(137)

[Arms, legs, skins, muscles, even the plump bottom-up to now all these have had their obvious usefulness; only her sexual organ, urination is doubtless a use, has dubious other functions, but it is a hidden secret, and others cannot see it. While under her sweater or garment, her breasts are showing off themselves, $[\ldots]$. 
The adjective 'rounded' is derived from the verb 'round'. One meaning of 'round' as a verb is 'make or become round' (Hornby 1984/1990: 1008). 'Rounded' in the source text describes that the shape of the young girl's bottom has become round. The Chinese expression of 'rounded' is '成圆形的' [becoming round-shaped]. S/N and W/Q all render 'rounded' into ‘圆润(起来)' [(becoming) round and smooth]. The compound phrase '圆润' consists of two characters: ‘圆' and ‘润'. ‘圆' as an adjective means 'round' or 'circular' (Hui Yu 2011: 2008), qualifying the shape of an object. '润', when used as an adjective, means 'glossy, smooth, sleek' to qualify the surface of an object (Hui Yu 2011: 1378). The phrase '圆润', when used to qualify a part of the body (such as neck or arm), means ‘饱满而润泽' [plump and smooth] (Zhou Xingjian 1990: 815). '起来', when used after a verb or an adjective, indicates the beginning and continuation of an action (Hui Yu 2011: 1260), and here it is used to convey the meaning of 'becoming' implied in the source text. Hence, '圆润 (起来)' not only conveys the meaning of 'becoming round', but also indicates the fine texture of the skin. Tao and Li both translate 'rounded' into '丰满'. '丰' in the compound phrase can be used to describe one's appearance or posture as 'fine-looking, good-looking, handsome, full and round', and '满' means 'full'. When used to qualify the body or part of the body (such as face, breast, bosom, and figure), ‘丰满' implies ‘胖得匀称好看' [fat in a pleasant-looking way] (Zhou Xingjian 1990: 194, Hui Yu 2011: 2008). English expressions for ‘丰满' include ‘full and round, plump, full-grown, fleshy, and crummy' (Hui Yu 2011: 478). Thus the central meaning of '丰满' is plump, in which the sense of 'becoming' is absent. '圆润' [rounded and smooth] and ‘丰满' [plump] both are positive phrases and express the sense of 'plump'. Although the former does not have the 'full-grown' meaning of the latter, both give richer meaning than the source word 'rounded'. This amplification of meaning is more the result of different ways of expression in Chinese and English.

The adjective 'invisible' literally means 'cannot be seen' (Hornby 1984/1990: 610), and in the source text, stresses the physical feature of the female sexual organ. $\mathrm{S} / \mathrm{N}$ and $\mathrm{W} / \mathrm{Q}$ render 'invisible (to others)' into '不露(在外)' [not expose (to the outside)], while Tao and Li into '(别人)看不见'“(别人)无法看 到' [(others) cannot see]. In appearance, the two translations both reproduce the source text meaning; however, they imply different points of view. In the source text, what is 'invisible (to others)' is the girl's sex organ, which is vital for the chastity of a girl and thus must be carefully protected. ${ }^{2}$ In the source text, 'others' is not gender specific. Nevertheless, in Chinese culture, it is a hurt and disgrace for the female body to be seen by men, but not a problem to be seen by women. Therefore, although the Chinese translations of 'others' look ambiguous, it could be inferred that '在外 [to the outside]' and '别人' [others] actually refer to men. ${ }^{3}$ This can be identified especially in the expression '不露 (在外)' [not expose (to the outside)], which adopts a female point of view: the girl does (will, shall, should, etc.) not expose her sex organ to the outside (i.e. men). It reveals a kind of female instinct to protect the vital organ from being seen (by men). Such concern does not seem to exist in Tao's and Li's '(别人) 
看不见’ ‘(别人)无法看到’ [(others) cannot see], which adopts the point of view of others (i.e. men) and takes the female sexual organ as an object of the male gaze. This distinction is further reflected in the different translations of 'make their display'.

The noun 'display' means 'show' or 'exhibition', expressed in Chinese as “显露, 表现'. The Chinese expression for 'make a display of x' is “炫耀 $\mathrm{x}$ ' [ show off $\mathrm{x}$ ] (Hornby 1984/1990: 342). '炫' on its own can mean 'to dazzle'. '炫耀' as a transitive verb means 'dazzle, show off, flaunt' (Hui Yu 2011: 1840), and is used negatively to express 'using something to dazzle someone' (Zhou Xingjian 1990: 755). According to the context, 'make their display' is used for an objective description to indicate that the girl's breasts have grown to have visible shape. It does not contain the connotation of 'show off'. Tao's and Li's '炫耀 自己' / “炫耀着自己' [ show off themselves] conveys one of the dictionary meanings of 'display', giving the text the overtone that the young girl, by flaunting her breasts, is using them as a kind of sexual bait to dazzle the male onlooker(s), and she is (or at least her breasts are) actively conniving at the male gaze. Such translations turn the adolescent newly-grown large breasts into an object of male gaze. This is totally contrary to Beauvoir's intention in writing her book, as the aim of that work is to condemn the male perception of women as a sexual object in all ways. S/N's and W/Q's '显露出来' [become visible] sounds more objective and descriptive. '显露' means 'become visible, appear, reveal, manifest itself, show'. '出来' [come out], when used after a verb, indicates revealing, detecting, etc. (Hui Yu 2011: 1259 and 245). '显露出来' describes that the young girl's breasts become visible as a result of the growth of her body. In such translation, $\mathrm{S} / \mathrm{N}$ and $\mathrm{W} / \mathrm{Q}$ seem determined not to turn the adolescent's newly-grown large breasts into an object of the male gaze; while Tao and $\mathrm{Li}$ appear to be keen to do so, increasing the sexual charge with their translation. $\mathrm{S} / \mathrm{N}$ and W/Q's version conveys or embodies feminist stance, whereas Tao and Li's does not, but virtually subverts it. As a result, it could be said that the male translators have 'manhandled' (my term) the text to promote their own view of the female body as a sex object, whether consciously, sub-consciously or unconsciously; whereas the female translators have 'womanhandled' the text to promote their own feminist view of the female body and its appearance (Godard in Simon 1996: 13).

The above comparison of the three cases shows an interesting phenomenon: the two sets of the female translators choose the same words and so do the male translators, while obvious differences exist between the translations by the female translators and by the male translators, particularly in terms of translation strategies and translation effects. In the case of 'rounded', although all the translators adopt amplification due to different ways of expression between the two languages, the translations by $\mathrm{S} / \mathrm{N}$ and $\mathrm{W} / \mathrm{Q}$ retain and convey the dynamics of the bodily growth, which is lost in the translations by Tao and Li. All the translators adopt repetition in the case of 'invisible', but the different points of view taken by the female and male translators result in different effects. S/N's and $\mathrm{W} / \mathrm{Q}$ 's translations to some extent reveal the cultural constraints on the 
female body and sexuality, while Tao's and Li's reflect the male gaze. In the case of 'make their display', $\mathrm{S} / \mathrm{N}$ and $\mathrm{W} / \mathrm{Q}$ use semantic translation to convey the contextual meaning, making the translations closer to the source text. Amplification is again used in Tao's and Li's translations of 'make their display', which carry richer meaning than the source text and reflect a male perspective or male gaze of the female body.

2 ST: My breasts, which until then had been hardly perceptible, began to swell softly and astonish me with charming but embarrassing sensations. (395)

$\mathrm{S} / \mathrm{N}$ : 我一向平平的双乳, 开始柔软地肿胀, 而使我惊奇地感受迷人却 又使人发窘的骚动。(143)

[My breasts, which had always been $\underline{\text { flat, }}$, began to swell softly, and surprise me with charming but embarrassing agitation.]

$\mathrm{W} / \mathrm{Q}$ : 我一向平坦的双乳, 开始柔软地膨胀, 我惊奇地感受到迷人却又 使人若迫的骚动。(172)

[My breasts, which had always been flat, began to swell softly, and I felt with surprise a charming but embarrassing agitation.]

Tao: 我的乳房在那以前几乎不为人察觉, 现在却松弛地隆起, 使我惊 奇地觉得它们既可爱, 又使我感到窘迫。(432-433)

[My breasts, which had been almost imperceptible, now swelled

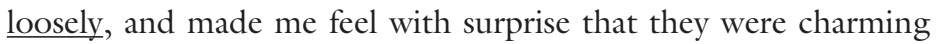
but also embarrassing me.]

Li: $\quad$ (cut) (161)

Example 2 describes the growth of the female body at adolescence. The word 'perceptible' means 'great enough for you to notice' (Hornby 2009: 1473). Similar to 'make their display' in Example 1, 'hardly perceptible' is used in the context to describe the girl's breasts as having not materialised into a visible shape. Tao translates 'hardly perceptible' into '不为人察觉' [imperceptible], meaning 'very small and therefore unable to be seen or felt' (Hornby 2009: 1022). It conveys the dictionary meaning or the surface meaning of the source text, in which 'the size' and 'to be seen' are stressed, giving the translation an implication that the female body is an object of the male scrutinising gaze. S/N's and W/Q's “平平的' “平坦的' [flat] conveys the deep meaning, or the contextual meaning, indicating the shape of the breasts of a young girl before the spurt of growth at puberty and describing a fact in the development of a girl's body.

The next case, 'swell softly', describes the growing of an adolescent girl's breasts. There is almost no difference between the source text and '柔软地肿胀/柔软 地膨胀' [swelled softly] by $\mathrm{S} / \mathrm{N}$ and $\mathrm{W} / \mathrm{Q}$, who simply repeat the source text expression. Whereas, Tao’s translation, ‘松弛地隆起’ [swelled loosely] indicates his uncertainty regarding the female body, especially when it is in the process 
of growth. ‘隆起’ means 'swell, bulge’ (Hui Yu 2011: 1026). ‘松弛地’ means 'loosely' or 'slackly' (Hui Yu 2011: 1533). Tao wrongly equates 'softly' with 'loosely' or 'slackly'. When something swells, it has an upward tendency, while 'loosely' means the opposite. If something is loose, it can hardly have an upward tendency but tends to relax, which is contradictory to anything in growth and creates a different image. This difference could be related to the lived experiences of the female and male translators.

$S / N$ 's and W/Q's semantic translation in the case of 'hardly perceptible' and repetition in translating 'swell softly' show their precise understanding and expressing of the source text meaning. Tao's literal translation of 'hardly perceptible' seems to bring the female body under the male gaze again, and his literal translation of 'swell softly' produces a mistranslation, disclosing his misunderstanding of the source text, or to be exact, misunderstanding of the state of the female body in growth.

3 ST: Even if she longs for caresses, she revolts at the idea of being seen and touched; and all the more since her breasts and bottom are a peculiarly fleshly growth. (401)

$\mathrm{S} / \mathrm{N}$ : 纵使她渴望爱抚, 她反对被看被摸; 特别因为她的胸脯与臀部 萌大异常; (149)

[Even if she longs for caresses, she opposes being watched and touched; especially due to her chest and bottom being abnormally fat and big.]

$\mathrm{W} / \mathrm{Q}$ : 即使她渴望爱抚, 她却反对被看被摸; 更因为她的胸脯与臀部 特别寿满; (179)

[Even if she longs for caresses, she opposes being watched and touched; especially due to her chest and bottom being particularly plump.]

Tao: 即使她渴望抚摸, 一想到被注视和触摸也会感到厌恶。自从她的 乳房和臀部发育得特别肉感以后, 情况反倒更是如此。(438)

[Even if she longs for caresses, she feels averse once thinking of being watched and touched. It is even more so since her breasts and bottom become particularly voluptuous.]

Li: $\quad$ (cut) (164)

This passage describes the physical appearance of an adolescent girl. Two words about the female body deserve attention here: 'breasts' and 'fleshly'. The word 'breast' refers to 'part of body' with three different meanings: (1) either of the two round soft parts at the front of a woman's body that produce milk when she has had a baby, expressed in Chinese '(女子的)乳房' [female breasts]; (2) the similar smaller part on a man's body, which does not produce milk, expressed in Chinese '(男子的)退化乳房' [male vestigial breasts]; (3) chest, i.e. the top part of the front of one's body, below one's neck, expressed in Chinese ‘胸脯, 
胸部' (Hornby 1984/1990: 141, Hornby 2009: 235). The first two are gender specific, while the third one is not. In the source text, 'breasts' refers to female breasts. S/N and W/Q translate it into '胸脯' [chest]; while Tao translates it as '乳房' [breast]. In Chinese culture, female '乳房' [breast] often gives an erotic association, while ‘胸脯’ [chest] has a less sexual implication. Therefore, ‘胸脯’ [chest] is often used as a euphemism for '乳房' [breast]. Traditionally, Chinese women usually feel shy concerning the terms for sexual organs and would not speak them out. The analysis of Chinese translations of TVM in Chapters Five to Seven will further illustrate this and show cultural constraints on women in terms of sex. Nevertheless, Chinese men are less constrained in (and seem to enjoy) talking about sex (usually with friends), including the female body. This could be the reason why Tao is more straightforward in rendering 'breasts', simply repeating the source term, while $S / N$ and $W / Q$ appear to be more conservative and choose to attenuate the sexual implication. Such attenuation is also applied in their translation of 'fleshly'.

The dictionary meaning of 'fleshly' is connected with physical and sexual desires (Hornby 2009: 774). This does not fit the context. In the sentence 'her breasts and bottom are a peculiarly fleshly growth', 'growth' as a countable noun means 'a lump caused by a disease that forms on or inside a person, an animal or a plant' (Hornby 2009: 774). Hence, the sentence conveys an unpleasant feeling of the girl towards her bodily growth. Thus, 'fleshly' refers to 'corporeal' in this context, with little connection with physical or sexual desire. Tao's '肉感' [voluptuous] expresses the dictionary meaning, giving the translation the implication that the girl's breasts and bottom have grown up to be sexually appealing. $\mathrm{S} / \mathrm{N}$ 's '肥大' [fat and big] has a negative connotation when used to refer to the human body, especially the female body, and hence better conveys the source text sense. This negative sense is lost in W/Q's '丰满' [plump], a positive term to describe the female body. Its meaning has been discussed in Example 1 and will not be repeated here.

This example shows that in translating the female breasts, all the translators reproduce the source text meaning; however, Tao is more straightforward, while $\mathrm{S} / \mathrm{N}$ and $\mathrm{W} / \mathrm{Q}$ are more conservative, showing the power of cultural constraints on women. In the case of 'fleshly', S/N's '肥大' [fat and big] conveys the contextual meaning; W/Q’s/“丰满’ [plump] is close to the source text meaning, but the negative sense is lost. Both $\mathrm{S} / \mathrm{N}$ and $\mathrm{W} / \mathrm{Q}$ do a sort of semantic translation, focusing on the physical appearance, whereas Tao's literal translation '肉感' [voluptuous] stresses the sexual appeal of the female body, showing a male perspective of looking at the female body.

4 ST: Her menstruation ceases, she grows stout, her breasts become heavy and tender, she suffers from vertigo and nausea; (523)

$\mathrm{S} / \mathrm{N}$ : 月经停止了, 身体粗肥了, 奶胀大了, 昏眩, 呕吐; (226-227) [Her menstruation ceases, her body becomes stout, her breasts have swollen, she feels dizzy and vomits; ] 
$\mathrm{W} / \mathrm{Q}$ : 月经停止了, 身体肥大了, 乳房更加丰满了, 她还由于头晕和呕 吐而难受。(289)

[Her menstruation ceases, her body enlarges, her breasts have become more plump, she suffers from vertigo and nausea;]

Tao: 她的月经停止了, 她变胖了, 她的乳房变得又大又娇嫩, 她头军 和呕吐。(565)

[Her menstruation ceases, she becomes fat, her breasts have become both big and delicate, she feels dizzy and vomits;]

Li: (cut) (197)

Example 4 is about the changes in the body of a pregnant woman. The adjective 'heavy' can mean 'fat' in describing the body, and 'tender' can mean 'painful when part of the body is touched' (Hornby 2009: 948/2082). Thus, 'heavy and tender' in the source text express what happens to the breasts when a woman is pregnant and also what the pregnant woman feels in her breasts. S/N's '胀大' [swollen] expresses such meaning. When a part of the body swells, it becomes larger and often feels painful. Hence, S/N's translation not only expresses the appearance, but also the delicacy and sensitivity of the breasts of a pregnant woman. W/Q's rendition '更加丰满' [more plump] describes the physical feature of a pregnant woman's breasts, expressing the larger size, but the feeling of pain is lost. In Tao's '又大又娇嫩' [both big and delicate], 'big' does render the size; however, the phrase '娇嫩' [delicate] conveys one of the dictionary meanings of 'tender', but not the contextual meaning. '娇嫩' [delicate] is often used positively in the Chinese language to express the beauty of the skin of a baby or young woman, of flowers or shoots, etc. (Hui Yu 2011: 789, Zhou Xingjian 1990: 313). '又大又娇濑' [big and delicate] shows a focus on the size and masculine feel of the breasts, and also reflects male gaze and masculine judgment. The pain brought about by the 'heavy breasts' is lost. In translating such content, lived experiences seem to be helpful.

\subsubsection{Women's psychology of their bodies}

Driscoll (1997: 94) pungently points out that women internalise 'patriarchal standards of bodily acceptability'. In her discussion of the development and changes of the female body, Beauvoir repeatedly points out the important fact of women's lack of confidence, shame or even dislike of their bodies. Examples 5 to 8 show that negative feelings about the female body may continue throughout a woman's life. That is to say, a woman may worry about her body all her life. Examples 5 to 6 are from 'Childhood', Example 7 from 'Sexual Initiation', and Example 8 from 'From Maturity to Old Age'. Examples 6 to 8 are absent in Li's abridged translation. 
5 ST: In themselves her breasts would seem to be a useless and obtrusive proliferation. (324)

$\mathrm{S} / \mathrm{N}$ : 乳房本身就显得无用, 讨厌。(66)

[The breasts themselves seem to be useless and a nuisance.]

$\mathrm{W} / \mathrm{Q}$ : 乳房本身就显得无用, 讨厌。(78)

[The breasts themselves seem to be useless and a nuisance.]

Tao: 她的乳房, 就本身来说, 好象是一种无用的、强加于人的增 生。(355)

[Her breasts, in and of themselves, are like a kind of useless and imposed proliferation.]

$\mathrm{Li}$ 就她的乳房本身来说, 就象是某种没有用的、强行加诸于她的赘 生物。(137)

[As far as her breasts are concerned, they are like some kind of useless and imposed excrescence.]

Example 5 (and 6) describes the distance of a young girl from her body in the process of her physical growth. The passage tells that the young girl feels ashamed of her body when her body changes shape and she is not yet psychologically prepared for the physical development of adulthood. In particular, she rejects the growth of her breasts which become a kind of burden to her childish carefree movement. The word 'obtrusive' means 'noticeable in an unpleasant way' (Hornby 2009: 1376), and 'proliferation' refers to 'the sudden increase in the number or amount of something' (Hornby 2009: 1586). The phrase 'obtrusive proliferation' implies the girl's dislike of her growing breasts and the embarrassment the girl feels because her breasts become noticeable. S/N and W/Q use “讨厌” [nuisance] to express such mentality. Tao renders into “强加于人的增生” [imposed proliferation] and Li into '强行加诸于她的赘生物' [imposed excrescence], both literal translation of the source text expression. Tao's “强加于人 的' [imposed] and Li's “强行加诸于(她)的' [imposed (on her)] reflect one of the dictionary meanings of 'obtrusive', but not the contextual meaning. The translations by Tao and Li both convey the girl's dislike, but the sense of embarrassment is lost. S/N's and W/Q's semantic translation and Tao's and Li's literal translation also produce different stylistic effects here. '讨厌' [nuisance] is daily language, which is fit for the language style of a child and conveys the emotions, while ‘强加于人的增生” [imposed proliferation]/强行加诸于她的赘 生物' [imposed excrescence] look scientific, fit for the genre of the academic work.

6 ST: At each recurrence the girl feels again the same disgust at this flat and stagnant odor emanating from her-an odor of the swamp, of wilted violets - disgust at this blood, less red, more dubious, than that which flowed from her childish abrasions. (329)

$\mathrm{S} / \mathrm{N}$ : 每发生一次, 女孩就再度经验对发自自身的凝滞臭味之厌恶一 一种类似沼泽, 或枯萎兰花的臭味一一并厌恶这污血, 暗红, 暧 昧, 与儿童跌伤时所流之鲜血颇不相同。(72) 
[At each recurrence, the girl experiences again the disgust at this stagnant foul odour emanating from her-an odour similar to that of the swamp or wilted violets-disgust at this dirty blood, dark red, dubious, very different from that which flowed from her childish injury from fall.]

W/Q: 每发生一次, 女孩就重新体验一次对发自自身的凝滞臭味之厌 恶一一种类似沼泽, 或枯萎兰花的臭味一一她庆恶这暗红、暖 昧的污血, 它与童年时代跌伤时流出的鲜血不一样。(85)

[At each recurrence, the girl experiences again the disgust at this stagnant foul odour emanating from her-an odour similar to that of the swamp or wilted violets-she is disgusted with this dark red, dubious dirty blood, which is different from that which flowed from her childish injury from fall.]

Tao: 每当月经重新出现时, 女孩都重新感到对身上发散出来的那种淡 淡的难闻气味——种沼泽地或枯萎紫罗兰的气味一一的厌恶, 对那种血的厌恶。这种血不象她小时侯受伤时那么红, 因而更可 疑。(360-361)

[Every time the menstruation recurs, the girl feels again the disgust at that faint unpleasant smell emanating from her-an odour of the swamp or wilted violets - disgust at that kind of blood. This type of blood is not as red as that which flowed when she was injured in her childhood.]

Li: (cut) (138)

Example 6 describes how the young girl is distressed by her menstruation. The differences in translating 'flat and stagnant odor' and 'this blood' are meaningful. '[F]lat and stagnant odor' describes the smell of menstruation. '[F]lat' can be used to qualify drink, meaning 'not fresh' and to qualify food, meaning 'stale' (Hornby 2009: 771). Flat drink or food gives out an unpleasant smell. '[S]tagnant' can be used to qualify water or air which 'is not moving and therefore smells unpleasant', and 'odor' refers to 'a smell, especially one that is unpleasant' (Hornby 2009: 1958 and 1380). S/N and W/Q both translate 'flat and stagnant odor' into ‘凝滞臭味' [stagnant foul odour], expressing the exact meaning of the source text. Tao renders it into “淡淡的难闻气味' [faint unpleasant smell]. '淡淡的' (meaning 'faint, vague') is a mistranslation of 'flat' and dilutes the sense of the bad smell that caused the disgust of the girl (Hui Yu 2011: 331). Moreover, the sense of 'stagnant' is lost.

Difference also appears in their translating 'this blood'. The determiner 'this' contains a sort of stress in the source text to distinguish menstruation from 'normal' blood. Such words as 'disgust' and 'dubious' reveal the girl's emotional distance from her body. $\mathrm{S} / \mathrm{N}$ and $\mathrm{W} / \mathrm{Q}$ translate 'this blood' into '这污血.' [this dirty blood], which amplifies the meaning of 'this blood' and expresses the girl's emotional distance from her menstruation. The words '污' [dirty] and '臭' [foul] not only explicate the reason why the girl is disgusted at this blood, but also 


\section{The female body and female sexuality in TSS}

to a degree disclose the emotion of the female translators about menstruation. In Chinese culture, menstruation blood is often regarded as dirty and sometimes is even connected with bad luck. One of the Chinese terms for menstruation is '倒霉' [bad luck], perhaps because menstruation often brings pain, inconvenience, and/or other sufferings to women. $\mathrm{S} / \mathrm{N}$ and $\mathrm{W} / \mathrm{Q}$ as women know very well how much women suffer from menstruation, and inevitably project their own experience into their translations. Tao translates 'this blood' into '那种血' [ that kind of blood], which expresses the source text meaning, but with a shift of determiner. 'That' as a determiner is used for referring to a person or thing that is not near the speaker or as near to the speaker as another (Hornby 2009: 2090). With '那种' [that kind of], the translator consciously or unconsciously or subconsciously distances himself from it. It sounds like an outsider commenting on menstruation, revealing a kind of detachment.

In this example, $\mathrm{S} / \mathrm{N}$ and $\mathrm{W} / \mathrm{Q}$ adopt the same strategies, either repeating or amplify the source text meaning, while the source text meaning is attenuated in both cases in Tao's translation, with the first case mistranslated. Gender (or lived experiences) seems to play a role here, reflected in $S / N$ 's and W/Q's amplified translation and Tao's mistranslation.

7 ST: Many young girls are distressed by these too thick ankles, these too meager or too ample breasts, these slender things, this wart; (401)

$\mathrm{S} / \mathrm{N}$ : 许多少女沮丧于太粗的足踝、太小或太大的乳房、太瘦的臀部、 某个疮肿; (150)

[Many young girls are depressed by the too thick ankles, too small or too big breasts, too thin hips, some wart;]

$\mathrm{W} / \mathrm{Q}$ : 许多少女对于太粗的足踝、太小或太大的乳房、太瘦的臀部、某 个疮肿都会感到沮丧; (180)

[Many young girls feel depressed by the too thick ankles, too small or too big breasts, too thin hips, some wart;]

Tao: 许多少女对这太粗的足踝, 这太王瘪或太丰满的乳房, 这太细的 大腿，这肉赘深感烦恼。(439)

[Many young girls feel distressed by these too thick ankles, these too wizened or too plump breasts, these too thin thighs, this wart;]

Li: $\quad$ (cut) (164)

This example describes not only the physical appearance of adolescent girls but also how they look at their bodies. Their psychology reveals that the female body is 'a site of shame' (Driscoll 1997: 101), because 'women, aware that they are always being watched and judged, internalise the male normative gaze and are controlled by it' (Bartky in Driscoll 1997: 102). In other words, women internalise 'patriarchal standards of bodily acceptability' which affect their 
'self-understanding' (Driscoll 1997: 94, 102). As a result, women survive by 'the gaze of others' (Ellmann, in Driscoll 1997: 103), which is in fact 'a form of obedience of patriarchy' (Bartky in Driscoll 1997: 103). The differences in the translations of the two adjectives ('meager', 'ample') and one phrase ('slender things') reveal different perspectives of the female and male translators.

The adjective 'meager' means 'thin, lacking in flesh' (Hornby 1984/1990: 713). It makes sense to describe the lacking-in-flesh breasts of adolescent girls as ‘小’ [small] as $\mathrm{S} / \mathrm{N}$ and $\mathrm{W} / \mathrm{Q}$ do. Tao's translation ‘干瘐” [wizened] means 'dry, dried-up, wizened, and shrivelled' (Hui Yu 2011: 510), which is more related to the aged body and seldom used to describe the adolescent body, and hence is a mistranslation of the source text meaning. The adjective 'ample' means 'large, often in an attractive way' (Hornby 2009: 62). However, according to the context, the girls 'are distressed' by their 'ample breasts', and hence would not regard them as something attractive. S/N's and W/Q's '大' [big] convey the contextual meaning. Tao's ‘丰满' [plump] conveys the surface meaning. As discussed in Example 1, '丰满' [plump] is a positive term for describing the female body, which would not cause 'distress'. In addition, '小' [small] and '大' [big] used by $S / \mathrm{N}$ and $\mathrm{W} / \mathrm{Q}$ are rather neutral and vague, while '干瘪' [wizened] and '丰满' [plump] used by Tao draw a vivid picture of both the size and shape of the breasts, revealing to some extent a masculine judgment of the female body.

In this example, the translations of 'slender things' also deserve attention. In the source text, 'slender things' is not explicit as to which part of the body it refers to. It is very vague and misleading, and could be understood as 'slender legs'. This could be the reason why Tao translates 'slender things' into '太细的 大腿' [ too thin thighs]. $\mathrm{S} / \mathrm{N}$ and $\mathrm{W} / \mathrm{Q}$ both translate into '太瘦的臀部” [too thin hips]. Then questions arise here: Which of the translations conveys the source text meaning? What does 'things' in the English source text really mean? The answers can only be found in the French original LDS. Parshley's 'slender things' is translated from the French original 'ces hanches maigres', meaning 'skinny or bonny hips' (Beauvoir 1949/1976: 159). Hence, the translations by $\mathrm{S} / \mathrm{N}$ and $\mathrm{W} / \mathrm{Q}$ reproduce the exact source text meaning and Tao's translation is a mistranslation, as 'thighs' refers to a different part of the body, to be exact, the part of the leg between the hip and the knee.

In this example, $\mathrm{S} / \mathrm{N}$ and $\mathrm{W} / \mathrm{Q}$ adopt the same strategy, repeating the source text meaning in all the three cases; while mistranslation appears in two of the three cases in Tao's translation. Tao's amplification in the other case discloses masculine judgement of the female body. Again, we seem to see the role of gender here.

8 ST: Long before the eventual mutilation, woman is haunted by the horror of growing old. (605-606)

$\mathrm{S} / \mathrm{N}$ : 早在身体发生变化以前, 女人就因害怕衰老而心绪不宁。 (361)

[Long before changes of the body happen, woman is haunted by the fear of growing old.] 
$\mathrm{W} / \mathrm{Q}$ : 远在身体发生变故之前, 妇女就由于耽心变老而提心吊胆。 (366)

[Long before changes of the body happen, woman is haunted by the fear of growing old.]

Tao：早在发生这种致使她的身体变得不健全的事故很久以前, 女人就 被变老恐惧缠绕着。(651)

[Long before the accident that leads to her body becoming defective happens, woman is haunted by the horror of growing old.]

Li: (cut) $(222)$

An important difference between the translations in this example is in rendering 'mutilation'. The verb of 'mutilation' literally means 'to damage sb's body very severely, especially by cutting or tearing off part of it (Hornby 2009: 1323). As this selected passage describes how women worry about getting old, 'mutilation' in the source text is meant figuratively, similar to the Chinese expression '残花 败柳' [withered flowers and willows], used to refer to the faded beauty of a woman usually above middle age. Here women are compared to flowers and willows which start to wither in autumn and perish in winter. In the source text, the 'mutilation' could be the wrinkles on one's face, hair growing white, teeth decaying, or an arthritic hip which makes one walk with great difficulty in an awkward and embarrassing way. Such changes of the body are normal to aged people of both genders, but women would worry or fear even before they appear. It again proves that women have internalised 'the male normative gaze and are controlled by it' (Bartky in Driscoll 1997: 102), and their self-understanding is based on 'patriarchal standards of bodily acceptability' (Driscoll 1997: 94, 102). Beauvoir intends to prevent women from 'obedience to patriarchy' with her analysis of woman's life (Bartky in Driscoll 1997: 103). S/N and W/Q translate 'mutilation' into ‘身体发生变化' / 身体发生变故' [changes of the body], conveying the source text meaning in a neutral and descriptive way, which somewhat removes the male normative gaze and patriarchal standards of bodily acceptability. Tao's '她的身体变得不健全' [her body becoming defective] conveys the surface meaning of the source text. '不健全' [defective] contains a negative sense and reflects patriarchal judgment of the female body.

\subsection{Translating female sexuality}

Female sexuality is an important part in the formation of woman and in the experience of woman's life, because 'eroticism is movement toward the other' (Vintges 1996: 29-30). Beauvoir discusses the development of female eroticism and various sexual experiences that accompany women's lives. She focuses largely on heterosexuality, except in 'The Lesbian' chapter. Her analysis exposes woman's erotic experience as almost always the experience of passivity (Fuchs 1980: 307). She intends to make women know themselves, be aware of patriarchal oppression, and move toward liberation. In discussing heterosexuality, Beauvoir frequently 
refers to the violent character of male sexuality, which is said to give the impression that 'intercourse between woman and man is a rather brutal affair' (Moberg 2000: 96). Several words repeatedly occur in Beauvoir's analysis of the heterosexuality happening to women at different ages: 'insert', 'penetrate', 'deflorate', 'defloration', and 'deflower'. Such words are often associated with violation of, violence against, or harm to women. The following examples show how the Chinese translators deal with the male 'brutality' in sexuality. Examples 9 to 10 come from 'Childhood', Examples 11 to 14 from 'Sexual Initiation', and Example 15 from 'The Married Women'. Examples 9, 11, and 13 to 15 are cut in Li's abridged translation.

9 ST: when her grandfather, an old man of seventy, tampered with her genitals, inserting his finger. The child felt severe pain but was afraid to speak of the incident. (336)

$\mathrm{S} / \mathrm{N}$ : 当时她的七十岁的老祖父, 玩弄了她的性器官并将他手指翟了进 去。那小孩感受强烈痛楚, 但不敢提起此事。(79)

[Then, her 70-year-old grandfather played with her sexual organ and poked his finger into it. The child felt intense pain, but did not dare to mention this incident.]

$\mathrm{W} / \mathrm{Q}$ : 当时她的七十岁的老祖父, 玩弄了她的性器官并将他的手指翟了 进去。那小孩感到激烈的疼痛, 但不敢提起此事。(93)

[Then, her 70-year-old grandfather played with her sexual organ and poked his finger into it. The child felt intense pain, but did not dare to mention this incident.]

Tao: 当时她的外祖父, 一个70岁的老头子, 用手指插进她的生殖器, 胡乱摸了一阵儿。这个孩子感到非常疼, 但不敢提起这件 事。(368)

[Then, her maternal grandfather, a 70-year-old man, inserted his finger into her sexual organ and fumbled about for a while. The child felt very painful, but did not dare to mention this incident.]

Li: $\quad$ (cut) $(140)$

This passage is taken from a story of domestic sexual harassment of a child. The verb 'insert' means 'put sth into sth else or between two things' (Hornby 2009: 1054). S/N and W/Q all translate it into '翟” [poke], meaning 'jab, stab, poke, prick, prickle, thrust' (Hui Yu 2011: 273). '翟' [poke] suggests that the action is done with force, which often results in pain or harm to the female victim in such instances, and expresses a stronger sense than the source text. Tao's translation '插' [insert] seems equivalent to the source text meaning. However, the following sentence has made it clear that the child 'felt severe pain'. Thus, Tao's literal translation fails to convey the contextual meaning. In addition, his translation of the adjective 'severe' (meaning 'extremely bad or serious') into '非常' [very], a general term in the Chinese language, does not sufficiently convey the degree 
of the pain the girl suffered (Hornby 2009: 1826). In comparison, S/N's “强烈' (meaning 'strong, intense, violent, vehement') and W/Q's “激烈' (meaning 'violent, acute, fierce, sharp, vehement, intense') better express the degree of the pain from the 'inserting' (Hui Yu 2011: 1284, 728). ‘羽倠' [poked] and “强烈” / 激烈' [intense] that the female translators use vividly convey the physical and psychological attack on the girl described in the source text, foreground the great shock and pain the girl suffered, and are much stronger than the more general words '插' [inserted] and '非常' [very] that Tao uses. The word choices of the female translators reflect not only the emotional implication of the source text, but also their own emotions against this kind of sexual attack on young girls. Tao's translation reads more like an 'objective' description of the incident, with the emotional implication lost.

10 ST: (In particular, the little girl is revolted when she realizes that she is virginal and closed, and that,) to change her to a woman, it will be necessary for a man's sexual organ to penetrate her. (320)

$\mathrm{S} / \mathrm{N}$ : 而要变成一个妇女, 她必须让一个男人的性器官翟入她体内。 (62)

[to become a woman, she must let a man's sexual organ poke into her body.]

$\mathrm{W} / \mathrm{Q}$ : 而要变成一个妇女, 她必须让一个男人的性器官翟入她体内。

[to become a woman, she must let a man's sexual organ poke into her body.]

Tao: 而要变成女人, 必须让男人的性器官插入她的体内 [...]。(351) [to become a woman, she must let a man's sexual organ insert into her body [...].]

$\mathrm{Li}$ 而要成为女人, 就要让男人的阳具插入她的体内 $[\ldots]$ 。(136) [to become a woman, she must let a man's penis insert into her body [...].]

Example 10 describes the girl's sexual psychology. The verb 'penetrate' is commonly used in describing sexual intercourse (Hornby 2009: 1469). Beauvoir repeatedly uses the word in her analysis of the heterosexuality happening to women at different ages. This and other examples (such as ST: 338-339, 403, 405 ) show that 'penetrate' not only means a physical violation which often brings suffering, but also imposes a kind of psychological threat to a woman. $\mathrm{S} / \mathrm{N}$ and $\mathrm{W} / \mathrm{Q}$ use the same expression '翟入' [poke into] to convey the same effect in this example and elsewhere in their translations of TSS (see S/N: 81, 151, 153; W/Q: 97, 182, 185). Tao and Li almost always use '插入' [insert], a word more neutral and general, which reduces the effect of the source text (see Tao/Li: 370/141, 371/141, 440/165, 443/165). Occasionally, Li uses 
'进入' [enter into] which is even weaker than 'insert' (see Li: 165). Such difference will also be seen in Example 11 in Chapter Five, where the female and male translators of TVM behave in the same way.

In Examples 11 to 15, 'deflorate', 'defloration' and 'deflower' are used. As they have the same meaning, they can be regarded as one word in different forms. For better comparison, I discuss the translations of them together.

11 ST: (who buys herself a young man;) she enjoys caressing him passionately but does not let him deflorate her. (397)

$\mathrm{S} / \mathrm{N}$ : 她享受热烈地安抚他, 但不让他翟进她。(145)

[she enjoys caressing him ardently but does not let him poke into her.]

$\mathrm{W} / \mathrm{Q}$ : 她享受热烈地安抚他, 但不让他翟进她。(174)

[she enjoys caressing him ardently but does not let him poke into her.]

Tao: 她 [...]享受着他的热情抚摸, 却不许他和自己性交。(434)

[she [...] enjoys his passionate caresses but does not allow him to have sexual intercourse with her.]

Li: $\quad$ (cut) (162)

12 ST: who feels insulted by his wife's resistance and even enraged if the defloration is difficult. (402)

$\mathrm{S} / \mathrm{N}$ : 若妻子抵抗, 则感觉受辱; 若翟入困难, 则甚至发脾气。 (151)

[If his wife resists, he will feel insulted; if poking into is difficult, he may even lose his temper.]

$\mathrm{W} / \mathrm{Q}$ : 如果妻子抵抗, 他会感到受辱; 若翟入困难, 他甚至发脾 气。(181)

[If his wife resists, he will feel insulted; if poking into is difficult, he may even lose his temper.]

Tao: 若是妻子反抗, 他会感到受辱, 若是破坏处女贞操进行得不顺 利, 他甚至会勃然大怒。(440)

[If his wife resists, he will feel insulted; if damaging the virgin's chastity is not smooth, he may even fly into a temper.]

$\mathrm{Li}$ : 要是妻子拒绝, 他会觉得羞辱, 要是破坏处女贞操的行动受到阻 碍，他甚至会怒不可遏。(164)

[If his wife rejects, he will feel humiliated; if the act of damaging the virgin's chastity is impeded, he may even become violently angry.] 


\section{The female body and female sexuality in TSS}

13 ST: (and two days later) a brutal defloration, carried out by force and in spite of pleas for mercy. (409)

$\mathrm{S} / \mathrm{N}$ : 不顾她的哀求, 他使用暴力残忍地翟破她。(158) [ignoring her supplication, by violence he brutally poked through her.]

$\mathrm{W} / \mathrm{Q}$ : 不顾她的哀求, 他使用暴力残忍地翟破了她。(190) [ignoring her supplication, by violence he brutally poked through her.]

Tao: 他不顾她的哀求, 用暴力残忍地夺走了她的处女贞操。(447)

[he ignored her supplication, and by violence, brutally took away her virgin chastity.]

Li: (cut) (167)

14 ST: Defloration is a kind of rape in this case. (403)

$\mathrm{S} / \mathrm{N}$ : 在这例子中, 处女之破坏即等于强奸。(152)

[In this case, damage of virgin amounts to rape.]

$\mathrm{W} / \mathrm{Q}$ : 在这一例子中, 处女的破坏就等于强奸。(183)

[In this case, damage of virgin amounts to rape.]

Tao：在这种情况下, 夺走处女贞操实际上是一种强奸。(441)

[Under this circumstance, taking away the virgin's chastity in fact is a kind of rape.]

Li: $\quad$ (cut 165)

$15 \mathrm{ST}$ : and often against those who have not attempted to deflower them during the first night or have been unable to do so. (465)

$\mathrm{S} / \mathrm{N}$ : 但也永远埋怨那不想或不能在头一个晚上翟破处女膜的男性。 (217)

[but always blame the man who has not wanted to or been unable to poke through hymen during the first night.]

$\mathrm{W} / \mathrm{Q}$ : 但也永远埋怨那些藐视自己, 不想或不能在新婚之夜给她以欢乐 的男性。(226)

[but always blame the man who has despised her, has not wanted to or been unable to give her happiness during the wedding night.]

Tao：并往往痛恨那些在第一夜不想或不能使她们失去处女贞操的 男人。(506)

[but always hate those who have not wanted to or been unable to make them lose their virgin's chastity during the first night.]

Li: $\quad$ (cut 183) 
The verb 'deflorate' (also deflower) is used figuratively in the source text, meaning 'deprive of virginity', especially by rupturing the hymen through sexual intercourse (Hornby 1984/1990: 311), and 'defloration' refers to the act of depriving a woman of her virginity. In the Chinese language, similar terms also exist, such as '采花' [pluck flower], '摘花' [pick/pluck flower], and '摧花' [destroy flower]. The virgin is likened to a flower and the first male (be this husband, lover, rapist) to 'pluck' that 'flower' 'deflorates/deflowers' her and robs her of her virginal chastity. The cultural charge of these terms involves precisely the act of rendering the woman no longer a virgin. Virginity in patriarchal culture is a 'must have'. Women would desperately want to hold on to it until their wedding night. In the old days, women were expected to be virgins on their wedding night. The surest proof that they were would be the appearance of blood following the breaking of the hymen when the penis is inserted right into the vagina. In certain cultures today where virginity is still very important, some women resort to cosmetic surgery to get the hymen repaired before the wedding night (see Example 4 in Chapter Five for further discussion). For the convenience of comparison, translations of 'deflorate', 'defloration, and 'deflower' are picked out from the passages and presented as below:

\begin{tabular}{|c|c|c|}
\hline$S T$ & $S / N$ and $W / Q$ & Tao and $\mathrm{Li}$ \\
\hline 11 deflorate & $\begin{array}{l}\text { 翟进 } \\
\text { [poke into] }\end{array}$ & $\begin{array}{l}\text { 和 ... 性交 (cut in } \mathrm{Li} \text { ) } \\
\text { [have sexual intercourse with] }\end{array}$ \\
\hline 12 defloration & $\begin{array}{l}\text { 翟入 } \\
\text { [poking into] }\end{array}$ & $\begin{array}{l}\text { 破坏处女贞操 } \\
\text { [damaging the virgin's chastity] }\end{array}$ \\
\hline 13 defloration & $\begin{array}{l}\text { 翟破 } \\
\text { [poked through] }\end{array}$ & $\begin{array}{l}\text { 夺走了她的处女贞操 (cut in Li) } \\
\text { [took away her virgin chastity] }\end{array}$ \\
\hline 14 Defloration & $\begin{array}{l}\text { 处女之破坏 } \\
\text { [virgin's damage] }\end{array}$ & $\begin{array}{l}\text { 夺走处女贞操 (cut in Li) } \\
\text { [taking away the virgin's chastity] }\end{array}$ \\
\hline 15 deflower & $\begin{array}{l}\mathrm{S} / \mathrm{N}: \text { 唯破处女膜 } \\
\text { [poke through hymen] } \\
\mathrm{W} / \mathrm{Q}: \text { 给她以欢乐 } \\
\text { [give her happiness] }\end{array}$ & $\begin{array}{l}\text { 使她们失去处女贞操 (cut in } \mathrm{Li} \text { ) } \\
\text { [make them lose their } \\
\text { virgin's chastity] }\end{array}$ \\
\hline
\end{tabular}

The translations of 'deflorate', 'defloration, and 'deflower' again show that the female translators almost use the same words or expressions and so do the male translators. S/N and W/Q use '准进' [poke into], '翟入' [poke into], and “翟破' [poke through] in Examples 11, 12 and 13 respectively, and $\mathrm{S} / \mathrm{N}$ use “准破' [poke through] in Example 15. The meaning of '翟' [poke] has been explained in Example 9. The words '进' [into], ‘入' [into], and '破' [through/ broken] after '翟” indicate either direction (进/入 [into]) or result (破 [broken/ through]). '翟进' [poke into], ‘翟入' [poke into] and '翟破' [poke through] focus on the physical act of 'poke', which often brings women physical and psychological suffering, and ignores the cultural implication surrounding the act of poking. This reflects a feminist intervention to challenge patriarchal control 
on women's sexuality. This is more evident in W/Q's rendition in Example 15, where 'deflower' is boldly translated as “给她以欢乐' [give her happiness]. This translation turns what many women would fear into a welcoming happiness, subverting the traditional image of heterosexual women. In Example 14, S/N and W/Q translate 'defloration' as '处女之破坏' [virgin's damage] (Hui Yu 2011: 253/1238), reproducing the source text meaning, with a focus on the violent nature of the act and the physical harm to the virgin. The translations by $\mathrm{Tao}$ and $\mathrm{Li}$ also reproduce the source text meaning, but with a focus on chastity, except that in Example 11, Tao translates 'deflorate' into '和 ... 性交' [have sexual intercourse], which is rather formal and neutral, and does not contain the cultural charge.

$\mathrm{S} / \mathrm{N}$ in all the five examples and $\mathrm{W} / \mathrm{Q}$ in four of the five use the same strategy to reproduce the source text meaning, but attenuate the cultural charge. W/Q in one example womanhandle the text, reversing the traditional image of woman as a sufferer of sexuality into an enjoyer. Tao and $\mathrm{Li}$ reproduce the source text meaning and retain the cultural charge in all the examples, except for the one case in Tao's translation discussed above.

16 ST: (who buys herself a young man;) she enjoys caressing him passionately but does not let him deflorate her. (397)

$\mathrm{S} / \mathrm{N}$ : 她享受热烈地安抚他, 但不让他嚾进她。(145)

[ she enjoys caressing him ardently but does not let him poke into her.]

$\mathrm{W} / \mathrm{Q}$ : 她享受热烈地安抚他, 但不让他翟进她。(174)

[she enjoys caressing him ardently but does not let him poke into her.]

Tao: 她 [... . 享受着他的热情抚摸, 却不许他和自己性交。(434)

[she [...] enjoys his passionate caresses but does not allow him to have sexual intercourse with her.]

Li: (cut) (162)

The translations of the first half of the sentence 'she enjoys caressing him passionately' deserves attention, because the differences in the translations disclose important message seen from feminist perspective. This passage gives an example of female initiative in heterosexuality, which is not often seen because 'in a majority of women a passive sexuality has also developed since childhood' (Beauvoir 1993: 397). The translations by $S / N$ and $W / Q$ are the same and both reproduce the source text meaning. However, Tao reverses it, turning the rare female active sexuality back into 'normal' passive sexuality. It is difficult to understand this 'mistranslation'. Tao, as a researcher in women's studies, who devoted himself to translating such a long feminist work, should not have made such an obvious mistake. Such a translation well reflects the power of a patriarchal ideology on female sexuality. Tao seems to have 'lost' sight of the 
fact that the source text is a feminist text about women's sexuality. The subject of the sentence is 'she'. It is the woman who is caressing the man. Tao's translation transforms this significant act of sexual initiation on the part of the female into one in which she becomes the object upon which the lover bestows his caresses. In his version, the woman in love-making is back to playing the passive role she is expected to play. Tao simply reinforces this patriarchal attitude towards women in heterosexual love-making.

\subsection{Summary}

In the sixteen examples analysed above, six translation strategies are identified: repetition, attenuation, amplification, semantic translation, literal translation, and reversion. Table 4.1 summarises the number of times the strategies are used in the translations. Repetition is used more in the translations by the female translators, and attenuation is used more in the translations by the male translators, though the difference between them is not very big. Amplification is used equally in the translations by $S / N, W / Q$, and Tao. Semantic translation is used only by the female translators, and literal translation by the male translators. Reversion appears in one case in W/Q's translation and one in Tao's translation. In most cases, the female translators use the same or similar words or expressions, and so do the male translators, showing an interesting contrast between 'woman translation' and 'man translation' in the examples.

Different strategies produce different effects in transmitting feminism. The translations by $\mathrm{S} / \mathrm{N}$ and $\mathrm{W} / \mathrm{Q}$ on the whole reflect their sympathy to heterosexual women and their conscious or unconscious feminism, expressed in their condemnation of the sexual abuse, foregrounding the harm to heterosexual women, promoting a feminist view of the female body and female appearance, subverting the traditional image of heterosexual women, removing the male normative gaze and patriarchal standards of bodily acceptability, and challenging patriarchal control on women's sexuality (such as Examples 1(2-3), 2(1), 8, $9(1-2), 10,11,12,13$, and 15). Their lived experiences appear to influence

Table 4.1 Number of times the strategies are used (TSS, Examples 1-16, 24 cases)

\begin{tabular}{lccll}
\hline Strategie & $S / N$ & $\begin{array}{l}\text { W/Q } \\
\text { (No. of times) }\end{array}$ & $\begin{array}{l}\text { Tao } \\
\text { (No. of times) }\end{array}$ & $\begin{array}{l}\text { Li } \\
\text { (No. of times) }\end{array}$ \\
\hline Repetition & 9 & 8 & 6 & 2 \\
Attenuation & 6 & 7 & 9 & 1 \\
Amplification & 5 & 5 & 5 & 2 \\
Literal translation & - & - & 3 & 1 \\
Semantic translation & 4 & 3 & - & - \\
Reversion & - & 1 & 1 & - \\
Total & 24 & 24 & 24 & 6 \\
\hline
\end{tabular}

NB: Examples 2 to 4,6 to 9, 11, 13 to 16 are cut in Li's translation, and only six cases in four examples are involved here. 
their translation of the female body and female sexuality (such as Examples 2(2), 4 , and 6(1-2)). Compared with radical feminist strategies in the Euro-American context, their feminist interventions in the examples examined on the whole look mild (such as 1(2-3), and 2(1)), although 'womanhandling' happens once. The translations by $\mathrm{Tao}$ and $\mathrm{Li}$ in many cases reflect or retain the male gaze and masculine judgment or patriarchal view of the female body and female sexuality (such as Examples $1(2-3), 2(1), 3(2), 4,7(1-2), 8,11(1)$ and 16). In some cases, Tao and $\mathrm{Li}$ appear to be detached in translating the female body and female sexuality (such as Examples 6(2) and 10). In a couple of cases, their translations fail to sufficiently transmit the pain of or harm to the female victim (such as Examples 9(2) and 10). Four mistranslations appear in their translations of the female body and female sexuality, which seem to be due to lack of lived experiences (see Examples 2(2), 6(1), 7(1, 3)).

\section{Notes}

1 See Zheng Yangwen and Macdonald (2009) on the subject of naming and names in Chinese culture.

2 See discussion of Example 14 in Chapter Five.

3 See discussion of Example 14 in Chapter Five.

\section{Bibliography}

Bair, Deirdre (1990) Simone de Beauvoir: A Biography, New York: Summit.

Bartky, Sandra Lee (1997) 'Foucault, Femininity, and the Modernization of Patriarchal Power', in Katie Conboy, Nadia Medina and Sarah Stanbury (eds) Writing on the Body: Female Embodiment and Feminist Theory, New York: Columbia University Press, 129154.

Beauvoir, Simone de (1949/1976) Le deuxième sexe II, L'expérience Vécue, Paris: Gallimard (112th edition).

- (1975) Force of Circumstance, translated by Richard Howard, Harmondsworth: Penguin. The French original was first published in Paris by Librairie Gallimard in 1963.

_ (1993) The Second Sex, translated and edited by H. M. Parshley, New York: Knopf. Butler, Judith (1986) 'Sex and Gender in Simone de Beauvoir's Second Sex', in Hélène Vivienne Wenzel (ed.) Simone de Beauvoir: Witness to a Century, Yale French Studies, special issue, 72: 35-49.

Driscoll, Ellen (1997) 'Hunger, Representation, and the Female Body: An Analysis of Intersecting Themes in Feminist Studies in Religion and the Psychology of Women', Journal of Feminist Studies in Religion 13(1): 91-104.

Fallaize, Elizabeth (ed.) (1998) Simone de Beauvoir: A Critical Reader, London and New York: Routledge.

Felstiner, Mary Lowenthal (1980) 'Seeing The Second Sex Through the Second Wave', Feminist Studies 6(2): 247-276.

Flotow, Luise von (1997) Translation and Gender: Translating in the 'Era of Feminism', Manchester: St Jerome.

Forster, Penny and Imogen Sutton (eds) (1989) Daughters of de Beauvoir, London: The Women's Press. 
Fuchs, Jo-Ann P. (1980) 'Female Eroticism in The Second Sex', Feminist Studies 6(2): 304-313.

Hawthorne, Melanie C. (2000) 'Introduction', in Melanie C. Hawthorne (ed.) Contingent Loves: Simone de Beauvoir and Sexuality, Richmond, VA: Virginia University Press, $1-12$.

Hornby, A. S. (ed.) (1984/1990) Oxford Advanced Learner's Dictionary of Current English (4th edition, 2nd impression), A. P. Cowie (Chief ed.), Oxford: Oxford University Press.

- (ed.) (2009) 牛津高级英汉双词典（第7版） [Oxford Advanced Learner's EnglishChinese Dictionary] (7th edition), translated by Wang Yuzhang 王玉章, Zhao Cuilian 赵翠莲 and Zou Xiaoling 邹晓玲, Beijing: 商务印书馆 [The Commercial Press], Oxford University Press.

Hui, Yu 惠宇 (ed.) (2011) 新世纪汉英大词典 [A New Century Chinese-English Dictionary], Beijing: 外语教学与研究出版社 [Foreign Language Teaching and Research Press].

Li, Qiang 李强 (trans.) (2004) 第二性 [The Second Sex], Beijing: 西苑出版社 [Xiyuan Publishing House].

Moberg, Åsa (2000) 'Sexuality and Brutality: Contradictions in Simone de Beauvoir's Writings about Sexuality', in Melanie C. Hawthorne (ed.), 84-116.

Sang, Zhuying 桑竹影 and Nan Shan 南珊 (trans.) (1986) 第二性一一人 [ The Second Sex一Women], Changsha: 湖南文艺出版社 [Hunan Literature \& Art Publishing House].

Simon, Sherry (1996) Gender in Translation: Culture and Identity and the Politics of Transmission, London and New York: Routledge.

Tao, Tiezhu 陶铁柱 (trans.) (1998) 第二性（全译本）[The Second Sex (Complete Translation)], Beijing: 中国书籍出版社 [China Books Publishing House].

Vintges, Karen (1996) Philosophy as Passion: The Thinking of Simone de Beauvoir, translated by Anne Lavelle, Bloomington and Indianapolis: Indiana University Press.

Wang, Youqin 王友琴 and Qiu Xichun 邱希淳, et al. (trans.) (1988) 女人是什么 [ What is Woman], Beijing: 中国文联出版公司 [China Federation of Literary and Art Circles Publishing Corporation].Zheng, Yangwen and Charles J.-H. Macdonald (eds) (2009) Personal Names in Asia: History, Culture and Identity, Singapore: National University of Singapore Press.

Zhou, Xingjian 周行健 (ed.) (1990) 实用汉语用法词典 [A Dictionary of Practical Chinese Usage], Beijing: 国际文化出版公司 [International Culture Publishing Corporation]. 


\section{Translating the female body and female sexuality in The Vagina Monologues}

Because of the political implications, women's bodies, sexualities and eroticism, described from a woman's perspective, have been an important subject in feminist writing (see Beauvoir 1972, Jones 1981, Moi 1985 and 1999/2001, Belsey and Moore 1989/1997, Mills and Pearce 1996, Conboy et al. 1997, McClintock et al. 1997, and Price and Shildrick 1999). Writing about women's sexuality and eroticism have been regarded as a means to deconstruct and subvert the patriarchal control over women and the myths of women's image framed by a patriarchal society (Flotow 1997: 17). The Vagina Monologues (TVM) is a piece of such writing, a popular play about the female body and female sexuality, narrating women's erotic or violent sexual experiences for the purposes of consciousness-raising and activism. It is successful in 'stirring public discussion and private awareness about women's sexuality' and in the 'fight against violence against women' (Cheng 2004: 333). The major issues TVM is concerned with include the estrangement from and negative attitudes towards the vagina, sexual violence against women in society and at home, misogyny from men as well as from women themselves, and same-sex love. This chapter examines the three existing Chinese translations to see how the Chinese translators deal with the material on the female body and female sexuality that reflects the first three issues and what effects the strategies produce. Translation of same-sex love will be discussed separately in Chapter Six, together with the Chinese translations of the lesbian chapter from TSS. The comparison in this chapter consists of fourteen examples, in which eighteen cases of different translations that matter concerning gender and feminism are discussed. The analysis includes both lexical choices and sectional rewriting by the female and male translators.

\subsection{Translating 'vagina'}

No doubt, 'vagina' is the most important word in TVM, a work consisting of vagina stories. The estrangement from and negative attitudes towards the vagina are best reflected in 'the myths, shame, and fear' around it (Ensler 1998: XXV). Patriarchal culture has divided women's physical selves into 'the part we talk about' and 'the part we don't', and 'saying the unsayable' is believed to be able 
to save women's sanity (Steinem 2001: xii-xvi). In the first part of TVM 'I bet you're worried. ...', Ensler talks about various terms for vagina used by Americans from different parts of the USA (Ensler 2001: 5-6). The play's humour comes in part from these various names for female genitalia from different groups of women (Bell and Reverby 2005: 439). However, the vagina terms Ensler collects and lists are vernacular terms in America. Even an indigenous American may not know all of them since many of them are area-specific. We can image how challenging it is for the Chinese translators to render them. The following passage gives us a taste of the translators' strategies and creativity in meeting the lexical challenge in the first place:

I ST: In Great Neck, they called it a pussycat. [...] In Westchester they called it a pooki, in New Jersey a twat. There's 'powderbox,' 'derrière,' a 'poochi,' a 'poopi,' a 'peepe,' a 'poopelu,' a 'poonani,' a 'pal' and a 'piche,' [...]. (6)

Chen: 在‘大颈’地方, 人们称阴道为 pussycat (原意为‘猫儿’一泽注)。[... 在威斯彻斯特地方, 人们称阴道为 pooki, 在新泽西州, 人们称 阴道为 twat。除外, 阴道还有以下的称呼: powderbox (化妆盒一 译注, 下同)、derrière (臀部)、poochi (小狗)、poopi (噗噗声)、 peepe (尿)、poopelu、poonani、pal (朋友)、piche、[ . . . 。 (31) [In Great Neck, people called vaginas pussycat (originally means 'cat'-translator's note). [...] In Westchester, people called vaginas pooki, in New Jersey, people called vaginas twat. Besides, vaginas are also referred to in the following terms: powderbox (cosmetic case-translator's note, the same below), derrière (hips), poochi (pup), poopi (bubbling sound), peepe (urine), poopelu, poonani, pal (friend), piche, [...].]

$\mathrm{Yu}$ : 女人 3: 在纽约的格瑞德尼克, 她们叫它小猫咪。[...]

[Woman 3: In New York's Great Neck, they called it pussy cat] 女人 1 : 在威斯切斯特, 她们叫它pooki。

[Woman 1: In Westchester, they called it pooki] 女人 2: 在新泽西, 叫它 twat!

[Woman 2: In New Jersey, called it twat!]

女人 3: 还有叫它力量盒子, poochi, Poopi, Peepe, Poopelu, Poonani, Pal或是piche。

[Woman 3: also called it power box, poochi, Poopi, Peepe, Poopelu, Poonani, Pal or piche.]

Ai: (cut)

Chen Cangduo adopts bilingual translation for some of the terms, such as translating 'pussycat' as 'pussycat (原意为“猫儿”一译注)' [pussycat (originally means 'cat'—translator's note)]. Interestingly, he keeps the English terms in his 
translation, followed by the Chinese translation in brackets, turning the Chinese translation into a translator's note. He adopts zero translation for the other terms, simply presenting the English terms without Chinese translation or explanation, such as 'pooki' and 'twat', perhaps because such terms can hardly be found in general English-Chinese dictionaries. Yu Rongjun also adopts zero translation for some terms, such as 'pooki' and 'twat', and reproduces the meanings of the other terms in his translation, such as translating 'pussycat' as '小猫咪' [pussy cat]. Besides, Yu Rongjun makes it explicit in his translation that Great Neck is located in New York, which is better known to Chinese people. Incidentally, he mistranslates 'powderbox' as '力量盒子' [power box]. Bilingual translation and zero translation in this case could be problematic to general Chinese readers or audiences, because very few Chinese people know the American vernacular terms. The foreign terms would mean little or nothing to Chinese audiences. Therefore, the English terms retained in Chen's and Yu's translations are merely strange terms with strange pronunciations to Chinese readers or audiences unless they are bilingual. Monolingual Chinese readers or audiences might well be bored with a long list of foreign terms. That could be the reason why Ai Xiaoming simply removes these terms, omitting them in her translation (Liu Weiming: 2004).

Perhaps to compensate for the strangeness brought about by the English terms, after dealing with the American vagina terms, Yu Rongjun adds many Chinese ways of referring to the vagina, bringing the play closer to Chinese audiences:

Yu: 女人 1 : 而在中国, 我们通常叫它 ......那个!

[Woman 1: But in China, we usually call it ... that!]

女人 2: 那玩意!

[Woman 2: That thing!]

女人 3 : 那东西!

[Woman 3: That stuff!]

女人 1 : 没毛的叫白虎精。

[Woman 1: Without hair, jinx.]

女人 2: 有毛的叫芳草地。

[Woman 2: With hair, fragrant grassland.]

女人 $3:$ 以前叫那活!

[Woman 3: Previously, that part!]

女人 1 : 现在叫妹妹! 网上叫MiMi!

[Woman 1: Now, younger sister! On the internet, MiMi!]

女人2: 不好意思时叫下身、下面、下体!

[Woman 2: When feeling shy, call it lower part of the body, lower part, private parts.]

女人 3: 可要好意思的时候, 就都叫 B, A、B、C、D的B!

[Woman 3: But when having the nerve, call it B: A, B, C, D-B!]

女人 1 : 大多数的时候, 我们通常总是很好意思。

[Woman 1: For most of the time, we usually have the nerve.] 
女人 2: 莎士比亚说过—-To be or not to be, that's a question!

[Woman 2: Shakespeare said-To be or not to be, that's a question!] 女人 3: 生存还是毁灭, 这是个值得考虑的问题。

[Woman 3: To survive or to perish, this is a question worth thinking of.] 女人 2: 生存不是问题, 阴道是我们的问题。

[Woman 2: Survival is not a problem, vagina is our problem.]

女人 $1 、 2 、 3:$ 我们真的很担忧, 真的, 我们为我们的阴道担忧。

[Woman 1, 2 and 3: We are really much worried, really, we are worried about our vaginas.]

In the Chinese ways of referring to the vagina, some are indirect, such as 那个 [that], 那玩意 [that thing], 那东西 [that stuff], 那活 [that part], 下身 [lower part of the body], 下面 [lower part], and 下体 [private parts]; some shocking and degrading, such as 白虎精 [jinx]; some very rough and vulgar, such as B (implying ' $b i$ 房' [cunt], Chinese slang and a vulgar term for vagina, often used as an obscene swear word or abusive term); some very poetic, such as 芳草地 [fragrant grassland]; and some quite modern and fashionable, such as MiMi. These Chinese terms for the vagina not only sound familiar to Chinese audiences but also create some humorous effect, making the scene livelier. Perhaps not every Chinese knows all these terms because people from different parts of China and people of different generations have different ways to refer to the vagina, similar to the American case in the source text, but this mixture of knowing and ignorance may arouse interest among the audience.

In ending the section, Yu Rongjun makes creative use of intertextuality by quoting the well-known line by Shakespeare, 'to be or not to be'. Like 'B' discussed above, 'be' is a kind of wordplay here, which intimates the vulgar Chinese vagina term ' $b i$ 㞕' [cunt] and enhances meaning through sound. This quotation is obviously intended for humour, especially among bilingual audiences. Following the sentence structure of 'to be or not to be', Yu Rongjun produces the line: 'To survive or to perish, this is a question worth thinking of'. This increases the dramatic as well as humorous effect of his translation. Of course, this effect would only work for well-educated audiences, but all the same, it is imaginative. More to the point, it is in conformity with the feminist stance, which requires that the source text be handled as humorously as possible in order to do the job of celebrating all forms of female sexual expression, including lesbian love-making. With the added Chinese terms, Yu Rongjun projects a Chinese voice into the global movement that begins with American voice-overs. This rewritten part is the prelude in Yu's translation.

As in Yu's translation, the first part of TVM 'I bet you're worried. . . ' is also the prelude in Ai's translation. In addition to omitting the vagina terms as just mentioned, Ai Xiaoming combines this section with the introduction in the 1998 English version (Ensler 1998: xix-xxv) and rewrites them into a prelude fit for her translation. The beginning of the introduction, particularly the underlined parts, shows the context of the play: 
'Vagina.' There, I've said it. 'Vagina'-said it again. I've been saying that word over and over for the last three years. I've been saying it in theatres, at colleges, in living rooms, in cafes, at dinner parties, on radio programs all over the country. I would be saying it on TV if someone let me. I say it one hundred and twenty-eight times every evening I perform my show, The Vagina Monologues, which is based on interviews with a diverse group of over two hundred women about their vaginas.

This passage clearly constructs a Western context by describing how (over and over for the last 3 years), where (in theatres, at colleges, in living rooms, in cafes, at dinner parties, on radio programmes), and when (every evening when I perform my show) 'I' have been saying the word 'vagina'. None of these three factors concerning TVM productions can be found in China. Ai Xiaoming moves the scene into a more specific Chinese student context by describing when (from first access to this script to starting rehearsal) and where (in classrooms, in seminars, in dormitories, in gatherings, in research and rehearsals) 'we' have spoken the word:

甲: ‘阴道', 我说出来了。

[A: 'Vagina', I've spoken it out.]

乙: '阴道', 我再说一遍。

[B: 'Vagina', I said it again.]

甲: 从读到这个剧本, 到开始排练, 我们一直不断重复这个词; 我们在教 室里说、在学术研讨会说、在寝室说、在聚会中说; 如果有可能的话, 我们愿意到全国各地巡回演出说。每次演出“阴道独白”, 我们都要说 它个一百二十八遍。

[A: From first access to this script, to starting rehearsal, we have kept speaking this word; we have spoken it in classrooms, in seminars, in dormitories, in gatherings; if possible, we would like to speak it in touring performances all over the country. We said it one hundred and twenty-eight times in each performance of The Vagina Monologues.]

甲: 我们说出 “阴道”, 是在研究和排练中获得的勇气; 我们每个人都是这 样。

[A: We speak out 'vagina', because we have gained the courage in research and rehearsals; it is true to each of us.]

The section 'I bet you're worried...' starts with a lengthy talk about why Ensler repeatedly says the word 'vagina'. Ai Xiaoming condenses the reasons into a few lines, quickly bringing in the 'worry' motif, in a different way, a way pertinent to the context and the audience:

乙: 在座的观众, 你们或许很担心, 担心我们怎么表演这出戏。

[B: Audiences here, maybe you're worried, worried about how we will perform this play.] 
甲: 我也很担心, 我担心的是: 人们为什么对这出戏心存疑虑。我担心人 们如何说“阴道”这个词, 我更担心人们不说这个词。我担心我自己的 阴道。

[A: I am also worried. What I am worried about is: Why people are doubtful of this play. I am worried about how people would say the word 'vagina'; I am even more worried that people would not say this word. I am worried about my own vagina.]

Cf: I bet you are worried. I was worried. That's why I began this piece. $\underline{\mathrm{I}}$ was worried about vaginas, and even more worried that we don't think about them. I was worried about my own vagina. (Ensler 1998: 3)

Ai's version is concerned that Chinese people are too conservative even to say the word. The production serves to break the ice and push women (and men) to face and value women's bodies. In TVM, the worry is that women ignore their bodies. Hence, women should take care of their bodies. Expressed slightly differently, the essence of the English and Chinese versions is the same: women's bodies have been neglected for too long, which should be changed. Subsequently, Ai Xiaoming uses the second and the last two paragraphs of the 'Introduction' to finish the prelude of her script, omitting the lengthy explanation of the necessity to talk about vaginas (in Introduction) and the terms Americans use for vaginas (in 'I bet you're worried....'). This brief prelude quickly brings the audience into the play.

In this example, Chen's bilingual translation and zero translation convey the least information to a monolingual reader; Yu's zero translation and intertexuality in English also convey little information to a monolingual reader, but the loss is compensated in a way though his addition. His rewriting reveals his feminist stance in translating this feminist text. Ai Xiaoming's omission of the American vagina terms and her adapting the prelude to a Chinese student context reflect her consideration of reception, helpful in transmitting feminism in the local context.

The next example is about vagina talks. In TVM, there is a section 'If your vagina could talk, what would it say, in two words' (Ensler 2001: 19-21). Ensler gives many answers to this question. The question and answers are amusing, but it is difficult to translate the questions in two Chinese words, though the answers Ensler herself gives are not all in two words, sometimes in three words or more. The following excerpt shows how the Chinese translators deal with the difficulty: 


\begin{tabular}{|c|c|c|}
\hline$S T(19-20)$ & Chen (41-42) & $r_{u}$ \\
\hline $\begin{array}{l}\text { Slow down. } \\
\text { Is that you? } \\
\text { Feed me. } \\
\text { I want. } \\
\ldots \\
\text { Let's play. } \\
\text { Don't stop. } \\
\text { More, more. } \\
\ldots\end{array}$ & $\begin{array}{l}\text { 如果你的阴道会讲话, } \\
\text { 它会说些什么? 两个字。 } \\
\text { [If your vagina could talk, } \\
\text { what would it say, in } \\
\text { two words?] } \\
\text { 慢慢 (Slow down)。 } \\
\text { 是你? (Is that you?) } \\
\text { 喂我 (Feed me)。 } \\
\text { 我要 (I want)。 } \\
\text { ․ } \\
\text { 我们来玩 (Let's play)。 } \\
\text { 不要停 (Don't stop)。 } \\
\text { 更多, 更多 (More, more)。 } \\
\text {... }\end{array}$ & 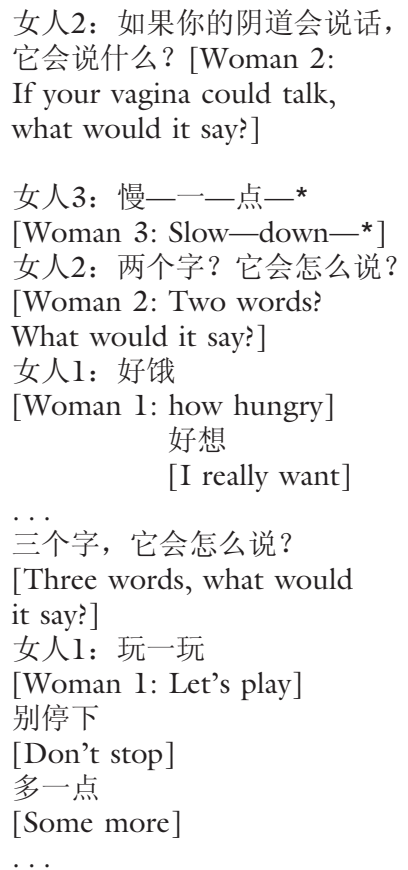 \\
\hline
\end{tabular}

Chen Cangduo adopts bilingual translation again, but in this case, he attaches the English original in brackets after his Chinese translation of each answer. The answers in the source text are given in a very poetic way, brief, beautiful and humorous. Chen's translation looks very mechanical, which pays little attention to poetics and hardly conveys the intended humour of the source text. Yu's translation again shows his creativity. Since the original question suggests an answer in 'two words' and it is hard to translate each answer in exactly two Chinese words, Yu Rongjun breaks the original question into two in his translation: ‘两个字? 它会怎么说?’ [Two words? What would it say?] and ‘三个字, 它会怎么说?' [Three words, what would it say?], and then answers the questions in two words and three words respectively. This adaptation solves very well the problem caused by language difference, and retains both the sense and beauty of the source text. Ai Xiaoming resorts to omission again, possibly due to time constraints for a production as she adds local stories in her translation (see Chapters Three and Seven).

Another challenge for the translators comes from the short onomatopoeic monologue 'Reclaiming Cunt' (Ensler 2001: 101-102), in which Ensler explicates the spelling and pronunciation of the word 'cunt'. 'Cunt', as taboo and slang, refers to a woman's vagina and outer sexual organ, and is also a very offensive word used to insult someone and to show anger or dislike (Hornby 
2009: 488). This abusive term is considered the most offensive swearword in referring to a woman. Betty Dodson, a 1960s liberal feminist leader whose life's work aimed at demystifying women's sexuality, tells Ensler that 'cunt' is her favourite word for the female genitals because this old Anglo-Saxon noun includes all the parts, and it sounds strong (Dodson 2001, McElroy 2002). Ensler reclaims it in her play because she loves its 'deliciousness, and the all-inclusiveness and the fierceness' (Braun and Ensler 1999: 518). This monologue celebrates the curves and hardness of the word by simple recitation. It usually involves an actress leading the audience in a chant of the obscene slang term, which creates much humour and often makes the performance hilarious. Though short, it is very difficult to reproduce in the Chinese language the sound effect of the English text.

3 ST: I call it cunt. I've reclaimed it. 'Cunt.' I really like it. 'Cunt.' Listen to it. 'Cunt.' C C, Ca Ca. Cavern, cackle, [...] then, $\mathrm{u}$-then $\mathrm{cu}$-then curvy, [...] ugh, $\mathrm{u}$-then $\mathrm{n}$ then cun-snug letters fitting perfectly together [...], then $\mathrm{t}$ - then sharp certain tangy t-texture, take, [...] tell me, tell me 'Cunt cunt,' say it, tell me 'Cunt.' 'Cunt.' (101-102)

Chen: 我把它称为 孔儿' (cunt), 我已经收回它, ‘孔儿’。我真的喜欢它, ‘孔儿’。倾听它吧。‘孔’。C C, Ca Ca. Cavern (洞一译注, 下同), cackle (呵呵笑), [ . . ] 然后是 $\mathrm{u}$ 一然后是 $\mathrm{cu}$ 一然后curvy (曲线美的), [...] 然后是 $n$, 然后cun一舒适的字母完美地契合在 一起。[ . . . 然后t一然后尖锐、确定、强烈的 $\mathrm{t}$ 一texture (触感), take (取), [...] tell me (告诉我), tell me 'Cunt, cunt' (告诉我 ‘孔儿, 孔儿’), 说它, 告诉我“孔儿‘孔儿’。(94-95)

[I call it 'hole' (cunt), I have retrieved it, 'hole'. I really like it, 'cunt'. Listen to it. 'Hole'. C C, Ca Ca. Cavern (hole-translator's note, the same below), cackle (chortle), [...] then is u-then is $\mathrm{cu}$ -then curvy (curvaceous), [...] then is $\mathrm{n}$, then cun-comfortable letters perfectly fit together. [...] then $\mathrm{t}-$ then sharp certain tangy t-texture (sense of touch), take (get), [...] tell me (tell me), tell me 'Cunt, cunt' (tell me 'hole, hole'), say it, tell me-'hole' 'hole'.]

Yu: 我叫它 cunt, 虽然它的意思是阴道, 可是我要把它的意思找回来, 'cunt', 我真的很喜欢它, 'cunt', 你听, 'cunt', 这么发音, 克, 克, 卡, 卡, Cavern, 山洞, cackle, 咯咯地笑, [ . . 然后就是 $\mathrm{u}$, curvy, 弯弯的, [...] 然后是 $\mathrm{n}$, 接着是 $\mathrm{c}-\mathrm{u}-\mathrm{n}$, cun, 啊, 你 看, 这几个柔和的字母组在一起真是完美极了。 [ . . 接着就是 $\mathrm{t}$ 了, 强烈的, 刺激的 $\mathrm{t}$, texture, 质地, take, 感受, [...] 告诉 我, 对, 告诉我, 'Cunt, cunt,', 说, 对, 说, 跟着说, 告诉我一 'Cunt', 'cunt'。

[I call it cunt, though its meaning is vagina, but I want to retrieve its meaning, 'cunt', I really like it, 'cunt', you listen, 'cunt', pronounce in this way, ke, ke, ka, ka, Carvern, cave, cackle, giggle, 
$[\ldots]$ then is $\mathrm{u}$, curvy, arched, [...] then is $\mathrm{n}$, next is $\mathrm{c}-\mathrm{u}-\mathrm{n}$, cun, ah, you see, these soft letters combined together are really perfect. $[\ldots]$ next is $t$, sharp, tangy $t$, texture, quality, take, feel, [...] tell me, right, tell me, 'Cunt, cunt,', say it, right, say it, follow me, tell me-'Cunt', 'cunt'.]

Ai: (cut)

In this example, Chen Cangduo still uses bilingual translation for rendering the spelling and pronunciation of 'cunt', retaining in his translation the key terms from the source text, followed by the Chinese translations of them in brackets in the form of 'translator's note' (as he does in Example 1). He translates 'cunt' into '孔儿' [hole], a vulgar term for vagina. It is pronounced as kong'er, similar to the pronunciation of 'cunt', and hence reproduces both the meaning and sound of 'cunt'. Perhaps to avoid misunderstanding of '孔儿' [hole], he puts 'cunt' immediately after '孔儿' in brackets to specify the meaning. Yu Rongjun adopts the same strategy as Chen Cangduo, but with different presentation. He place the English terms side by side with the Chinese translations. In this section, he does not provide a Chinese translation for 'cunt', but explains that its meaning is vagina. The Chinese equivalent of 'cunt' is ' $b i$ 屏' [cunt], equally offensive in Chinese culture. Yu Rongjun has in a way reclaimed the Chinese term in the added Chinese expressions of vagina discussed in Example 1, though he uses the English letter ' $\mathrm{B}$ ' instead of ' $b i$ 屏' [cunt]. The example shows that Chen Cangduo and Yu Rongjun try hard to reproduce the sound effect with the bilingual translation strategy, which only works with bilingual readers or audiences, though. Ai Xiaoming does not translate this monologue at all. She thinks that due to the 'different language background', the reclaiming of an English slang for vagina is not significant to the Chinese audience (Liu Weiming 2004).

Menstruation is an important female physical phenomena or experience. In TSS, Beauvoir talks at length about the impact of menstruation on the body and psychology of young girls, especially the first menstruation. Many women can find experiences similar to their own in the numerous examples Beauvoir gives. Coincidently, TVM also contains such stories. In the monologue 'I Was Twelve. My Mother Slapped Me' (Ensler 2001: 35-40), some young girls from seven to sixteen talk about their first menses: how they come to know, feel, and treat (and have been treated with) their period. The passage below foregrounds the differences of the strategies the translators use in dealing with such typical female bodily experiences:

4 ST: I was twelve. My mother slapped me.

Second grade, seven years old, my brother was talking about periods. I did not like the way he was laughing. I went to ask my mother. 'What's a period?' I said. 'It's punctuation,' she said. 'You put it at the end of a sentence.' [. . .] My mother made me hot water and wine, and I fell asleep. $(35,39)$ 
Chen: 我十二岁。母亲掌掴我。

[I was twelve. My mother smacked me.]

我二年级, 七岁, 我的哥哥在谈论月经。我不喜欢他笑着的样 子。我跑去找母亲。'月经 (period) 是什么?' 我说。'它是一种 标点符号 (按“月经”的原文period也有“句点”的意义一一译者注), 她说。“是使用在一个句子结束的时候。” [... 我的母亲为我准备 热水和酒, 我睡着了。(54,59)

[I was in second grade, seven years old, my brother was talking about menstruation. I did not like the way he was laughing. I went to ask my mother. 'What's menstruation (period)?' I said. 'It is a kind of punctuation (according to the original word "period", "period" also has the meaning of "punctuation"translator's note),' she said. 'It is used at the end of a sentence.' [...] My mother prepared hot water and wine for me, I fell asleep.]

Yu: (cut)

Ai: 初潮

[Menarche]

七岁时, 我二年级, 我的哥哥开始说什么 “一月一次”。我不喜欢 他大笑的样子。我找妈妈问: “谁一月来一次?”。妈妈说: ‘一个朋 友”, 她说: ‘就像收水电费的人一样。” [...]我妈给我保红糖水, 接着我睡着了。

[Seven years old, I was in second grade, my brother started talking about something 'once a month'. I did not like the way he was laughing. I went to ask my mama: 'Who comes once a month?' Mama said: 'A friend,' she said, 'like the one who comes to collect utilities fees.' [...] My mum cooked brown sugar water for me, and I fell asleep.]

Chen's translation of this monologue is literal as usual, which occasionally fails to convey the deep meaning or contextual meaning of the source text, though it may look very faithful in appearance. His translation of the title 'I Was Twelve. My Mother Slapped Me.' is a case in point. The title refers to the mother's response when she knows the appearance of her daughter's menses. The word 'slap' can be used in two ways: to hit hard or smack angrily, or hit in a friendly manner, depending on the context (Hornby 2009: 1884). In the story, 'My mother said, "Mazel tov." She slapped me in the face.' (Ensler 2001: 38) Obviously, the mother is wishing her daughter good luck, because the first menses is usually regarded as an emblem of a girl's growing up. Hence the 'slap' should be one with love, rather than with anger. Beauvoir's analysis in TSS expounds how a mother would respond to the first menstruation of her daughter and how a young girl would respond to her first menstruation: 
No doubt the mother who brutally slapped her daughter, saying: 'Idiot, you are too young,' is exceptional. But more than one will show bad humour; most fail to give the child adequate information, and the latter remains filled with anxiety concerning the new status that the first menstruation inaugurates.

(Beauvoir 1972: 337)

This monologue from TVM further illustrates Beauvoir's analysis. Chen Cangduo translates 'slap' into '掌掴' [smack], giving the translation an implication that the girl did something wrong and was slapped by the angry mother, which is not the source text meaning. This monologue is excluded in Yu's translation. He might think that this monologue of young girls' menarche stories was less important for a commercial production and thus removed it. Ai Xiaoming leaves out the original title and replaces it with another one: ‘初潮' [Menarche], which is exactly what the monologue talks about and makes the title more intelligible to Chinese audiences.

'Period' is an informal word for 'menstruation', used in this example to pun. It appears several times in the monologues when the young girls talk about their experiences of their first menses. Throughout the monologue, Chen Cangduo translates the informal 'period' into 月经 [menstruation], a formal and medical term, and keeps the English word 'period' in brackets in his translation of the question 'What's a period?'. Then he translates the answer 'It's punctuation' into “它是一种标点符号” [It is a kind of punctuation] and adds a note in brackets to explain that “按“月经”的原文 period 也有“句点”的意义' [ according to the original word 'period', 'period' also has the meaning of 'punctuation']. This literal translation conveys the surface meaning, but the humorous effect from the punning is lost. Ai Xiaoming translates 'period' into '一月一次' [once a month], alluding to 'period', and translates the question 'What's a period?' into “谁一月来一次?' [Who comes once a month?]. The punning effect is conveyed through a Chinese pun used in her translation of the answer to the question: “一个朋友” [a friend], another allusion to 'period'. In Chinese culture, ‘老朋友' [old friend] is commonly used to refer to 'period', especially among young people or students. Ai Xiaoming completes her translation of the answer with ‘就像收水电费的人一样' [like the one who comes to collect utilities fees]. In China, a person who collects water and electricity fees comes once a month. Such localising or domestication preserves the humour of the source text, and evokes knowing smiles among Chinese audiences.

The rest of the monologue consists of the menarche stories of the young girls. Chen Cangduo translates each of them, literally. In a story, a girl said that when she was suffering from her period, her mother made her 'hot water and wine', and she fell asleep. This practice seldom happens in China. Chen Cangduo keeps close to the source text, rendering the foreign practice '我的母亲为我准 备热水和酒, 我睡着了。' $[\mathrm{My}$ mother prepared hot water and wine for me, I fell asleep.].

Ai Xiaoming localises or domesticates the menarche stories into Chinese ones that most Chinese women are familiar with, such as the menarche experiences 
of me, my mother and my mother's mother, including the Chinese ways to deal with periods at the time when there were no sanitary towels. A popular brand of sanitary towel '护舒宝' is referred to in one of the stories. '护舒宝', pronounced as 'Hushubao', is a very good transliteration of its English name 'Whisper', as it not only reproduces the pronunciation, but also contains the meaning of 'good and comfortable protection'. In another story, a traditional Chinese custom is mentioned that a girl should not wash her hair when her period comes, otherwise she will not give birth to a son in the future, which is vital to a traditional Chinese family. In Ai's translation, 'My mother made me hot water and wine, and I fell asleep.' is turned into a familiar Chinese practice: “我妈给我煲红糖水, 接着我睡着了。' [My mum cooked brown sugar water for me, and I fell asleep.]. In China, hot 'brown sugar water' is believed to be good for a woman during her period or in childbirth. The Chinese stories or experiences are said to be obtained from the students themselves, which bring the production closer to its target audiences. The Chinese elements would arouse echoes in a Chinese female audience, remind them of their own experiences, and amuse them when they read or watch it, because an important part of their 'common gender experience' is menstruation (Cao Shuying 2007). At the end of this piece, Ai adds a touching song about menarche called 'The First Time', which creates a climax for this scene.

This monologue has moved many female audience members and inspired further reflection on gender issues. They suggested that the production should include a discussion of the hymen and 'virginal complex' because these problems still afflict women in many parts of China (Cao Shuying 2007), and traditional values of chastity and virginity are still highly regarded even in cosmopolitan cities such as Shanghai (Farrer 2002). A recent news story on fake hymens and surgery to restore the hymen proves how deeply the ancient standard of being a traditional, virtuous woman is still ingrained in many men's minds (Lin Meilian 2010, also see Sigley 2006: 44). According to Burger (2012: 1), every year, thousands of Chinese women pay for an operation to restore their hymens shortly before their wedding, and those who cannot afford the operation fee can buy a cheap artificial hymen in a sex shop or online, so that husbands can see blood on the sheets on their honeymoon night. For some husbands, the absence of blood on the sheets can be a reason for divorce. In a way, Ai's production provides an opportunity for sharing experiences (Anonymous 2005a).

The next example is a short poem at the end of 'The Vagina Workshop'. The translations also show the different approaches of the translators.

5 ST: My vagina is a shell, a tulip, and a destiny. I am arriving as I am beginning to leave. My vagina, my vagina, me. (50)

Chen：我的阴道是一个贝壳, 一朵郁金香, 一种命运。我正要到达, 就 像我正要开始离开。我的阴道, 我的阴道, 我。(69)

[My vagina is a shell, a tulip, a kind of fate. I am arriving, as I am beginning to leave. My vagina, my vagina, me.] 
Yu: 我的阴道是一个贝壳, 一朵郁金香, 一个命运之神。当我到达 时, 我就开始离开, 我的阴道, 我的阴道, 我已经变成了我自己 的阴道。

[My vagina is a shell, a tulip, a god of fate. When I arrive, I begin to leave, my vagina, my vagina, I have become my own vagina.]

Ai: (下面的诗句, 用自己的自然、真诚、抒情的风格来处理, 表现出 作者认同自己的身体, 也认同了工作坊的理念: 让妇女重新获得 自己的身体, 赞美和肯定自己, 非常抒情和喜悦: ) 我的阴道是 一个贝壳, 一朵郁金香, 一种命运。我正在到达, 如同我正在离 开。我的阴道, 我的阴道, 我, 自己。

[(For the following verses, treat them in your own natural, sincere, lyric style; show the author's identification with her body, and with the idea of the workshop; let women regain their body, praise and affirm themselves, very expressive and joyful:) My vagina is a shell, a tulip, a kind of fate. I am arriving as I am beginning to leave. My vagina, my vagina, me, myself.]

The translations show little difference in understanding and expressing the poem. All the three translators keep close to the source text, reproducing the meaning of the English poem. However, Ai Xiaoming gives a note before the poem, giving detailed instructions for performers, explicating the feminist message and underlining the purpose of the play: let women regain their bodies and praise and affirm themselves. In Ai's translation, there are many such in-text parenthetical notes to give detailed explanations and directions of how to understand and present the lines, and what effect to achieve on the stage (also see Example 13). The notes explicate and foreground the feminist message to performers so that they can catch the feminism of the play and convey it to the audience. Unlike the notes Chen uses in his translation, Ai's in-text parenthetical notes serve feminist purposes, similar to the 'paratexts' or 'metatexts' used by Western feminist translators (Genette 1997: 1-2, also see 2.1.1). Paratexts is one of the major strategies Ai Xiaoming uses in her translation.

Chen uses nine short in-text parenthetical notes in his 113 pages of translation (see Chen 2000: 5, 8, 11, 31, 41, 46, 87 and 94, also see Examples 1, 3 , and 4). These notes are usually given to explain some terms or names in case a Chinese audience may not know them, such as who Eisenhower was (see Example 12). These notes are not 'feminist', but rather intended to make the source text intelligible to the Chinese audience. As Chen's translation is not intended for the stage, it is understandable that it contains no stage directions. Yu's translation is intended for the stage, but there are only three short endnotes and a few prompts. For example, at the beginning of the script, Yu Rongjun gives the following stage directions: '人物: 女人 1、女人 2、女人 3 ' [Characters: Woman 1, Woman 2, Woman 3], and in the next line, he gives a note in brackets: '这个剧本是三个演员的版本, 也可以根据实际演出需要, 用任何数量的女 演员来进行演出。' [This script is a three-actress version. It can be used for 
performances by any number of actresses according to the practical needs of the performances.]. Some parts of his script are presented in the format of three actresses speaking lines alternately (see Example 1).

\subsection{Translating sexual violence}

Sexual violence is an important issue in TVM. Among the different forms of sexual violence, domestic sexual violence may be more harmful to women. It is often regarded as family trouble, thus more invisible and difficult to gain outside intervention, just as a popular Chinese saying makes clear: ‘清官难断家务事' [even upright officials would find it hard to settle domestic cases]. The monologue 'Hair' is an example of domestic sexual violence and sexual abuse. In 'Hair', the husband derived some kind of sadistic pleasure from shaving the pubic hair of his wife before making love to her, completely ignoring her psychological and physical reaction to it. Shaving excited the man, but the woman was injured and suffered pain, and hence refused to be shaved. Then the couple went to see a marital therapist in order to save their marriage. The marital therapist suggested to the wife that she should 'compromise', 'jump in', in order to get 'a good beginning' (Ensler 2001: 10). The result is that the husband felt encouraged to impose his will on his wife, and she suffered more. The following examples from 'Hair' exhibit differences between the translations.

6 ST: He made me shave my vagina. It looked puffy and exposed and like a little girl. This excited him. (9)

Chen: 他要我剃阴道的毛。剃完之后, 阴道看起来膨胀、暴露, 像一个 小女孩。这种景况令他兴奋。(34)

[He made me shave the hair of my vagina. After shaving, the vagina looked puffy and exposed, like a little girl. This look made him excited.]

Yu: 他甚至要求我把我的阴毛给剃掉, 让它看上去暴露而光滑, 就像 个年轻的女孩子。而这会令他很兴奋, 可我就惨了。

[He even asked me to shave my pubes to let it look exposed and

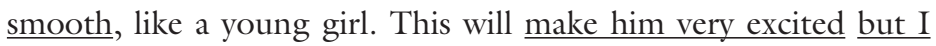
will be miserable.]

Ai: 他要我把它剃掉。剃完之后, 我的阴道看起来膨胀、暴露, 像一 个小女孩。这个样子令他格外兴奋。

[He made me shave it. After shaving, my vagina looked puffy and exposed, like a little girl. This look made him extremely excited.]

The adjective 'puffy' refers to '(eyes, faces, etc.) looking swollen (= rounded, larger, etc. than usually)' (Hornby 2009: 1602). Here it describes the physical effect that shaving the hair has on the wife. Chen Changduo and Ai Xiaoming reproduce the source text meaning. Yu Rongjun translates 'puffy' as '光滑', 
which means 'smooth, glossy, sleek' (Hui Yu 2011: 597). ‘光滑' [smooth] is usually used positively, and hence fails to express the unusual look and feeling of the 'puffy' part of the body. In the source text, what excites the husband so much is that he has got his wife to shave off her pubic hair. Chen Cangduo remains faithful to the source text, reproducing the meaning of 'excited him'. Yu Rongjun adds a modifier '很' (meaning 'very, quite') for 'excited', increasing the tone of his translation (Hui Yu 2011: 653). Then he adds another sentence '可我就惨了 [but I will be miserable]' to emphasise the difference between the feelings of the husband and the wife. Ai Xiaoming also adds a modifier '格外' (meaning 'unusually, extraordinarily, extremely') to underline the sharp contrast between the psychological states of the husband and wife (Hui Yu 2011: 541). “格外' [extremely] gives the translation a much stronger tone.

Chen's performances in the two cases remain consistent, faithfully conveying the source text meaning. Yu's performance in the first case shows his failure to catch and convey the physical suffering of the woman; nonetheless, his addition in the second case embodies a feminist stance. Ai reproduces the source text meaning in the first case and her addition in the second case clearly exhibits her feminist stance.

7 ST: When he made love to me, my vagina felt the way a beard must feel. (9)

Chen: 当他跟我做爱时, 我的阴道感觉起来像胡子给我的感觉。(34)

[When he made love to me, my vagina feels what a beard makes me feel.]

Yu: 当我们做爱时, 我的阴道就像是刚刮过胡须的下巴。

[When we made love, my vagina was like a shaved chin.]

Ai: 当他跟我做爱时, 我的阴道就像被刺扎着。

[When he made love to me, my vagina was like being pricked by thorns.]

The translations of the when-clause by Chen Cangduo and Ai Xiaoming show no difference, all keeping close to the source text. In Yu's translation '当我们 做爱时' [When we made love], the subject 'he' becomes 'we', which fails to convey the unequal position between the husband and wife and the wife's unwillingness in the sexual activity.

The main clause 'my vagina felt the way a beard must feel' describes the wife's physical feeling as a result of the shaving, i.e. the sharp pain she felt. Ensler uses 'a beard', as an analogy, comparing shaving pubic hair to shaving a beard in order to express the feeling of the wife whose pubic hair was shaved. The analogy, together with the auxiliary verb 'must', conveys the sense of estrangement of this part of the female body, after being submitted to the man's request. Frankly, a female reader may not readily catch the effect of this analogy. However, there is little vocabulary available for describing women's sexuality in patriarchal discourse and sexual activity is mostly described from a male point of view. This 
to some extent shows the predicament feminists have long faced: feminists do not have a language of their own and they have to express feminism in patriarchal language in a patriarchal world. With this analogy, Ensler perhaps intends to make the woman's experience easily understandable to men so that such violations of women can be reduced in the future.

Traditionally, many men regard beards to be a sign of their masculinity. Many women regard pubic hair to be a sign of their femininity. Hair on the face or under the armpits is considered by many women to be embarrassing or detracting from their appearance. They spend a lot of time and money getting rid of it. However, pubic hair, not on public display, is different. It is not a common practice for women to get rid of it. When the husband, given his idiosyncratic perversion, insisted that his wife shaved it off, and when she finally gave in, she felt naked and exposed, just as a man might feel naked and exposed if he is forced to shave off his beard. A newly shaven face feels raw as well as rough and hurts the hand which touches it. Strictly speaking, it is the man with the shaven chin who feels this way, just as it is the woman whose pubic hair has been shaven off feels the way described. But Ensler achieves a more dramatic effect by making body parts speak for themselves, abandoning the normal way of saying that it is the whole person who speaks for himself/herself. Hence it is the vagina that feels 'the way a beard must feel'. It is the vagina that has been insulted, humiliated and hurt by the husband's insistence that its pubic hair be shaved off, just as a beard might similarly feel insulted, humiliated, and hurt if someone were to order a man to shave it off.

Chen Cangduo appears to have misunderstood the source text, as in his translation ‘我的阴道感觉起来像胡子给我的感觉' [my vagina feels what a beard makes me feel]. That means it is no longer about the beard's own feelings, but simply what the beard makes the woman herself feel, which is ambiguous, and not necessarily as negative as the source text. Actually, his translation does not make much sense in the Chinese language. This may be the result of his literal translation strategy. Yu Rongjun comes closest to capturing the feminist charge of the source text with '我的阴道就像是刚刮过胡须的下巴' [ my vagina was like a shaved chin]. Ai Xiaoming leaves the analogy, and uses another analogy to express the effect of the shaving: ‘我的阴道就像被刺扎着' [my vagina was like being pricked by thorns], which conveys the contextual meaning and foregrounds the pain resulted from the shaving- 'it felt like it was on fire' (Ensler 2001: 9). Her translation is consistent with what the source text tries to show (sexual inequality between men and women in the family) and also reveals her sympathy to the wife. As a woman, Ai Xiaoming can perceive what the wife was suffering both psychologically and physically.

In this example, Chen's performance fails to keep consistency in the two cases. $\mathrm{He}$ is able to reproduce the source text meaning in the first case, but fails to make sense in the second case. Yu Rongjun fails to convey the unequal position between the husband and wife and the wife's unwillingness in the sexual activity the first case, but catches and conveys very well the feminist charge in the second case. Ai Xiaoming reproduces the source text meaning in the first case, 
and reproduces the contextual meaning with another analogy in the second case, making the source text meaning (the psychological and physical suffering of the woman) more intelligible to Chinese readers or audiences.

8 ST: he said he screwed around because I wouldn't please him sexually. I wouldn't shave my vagina. (10)

Chen: 他说他去玩女人, 因为我不在性方面取悦他, 因为我不剃阴 毛。(34)

[he said he went to womanise, because I didn't please him sexually, and because I didn't shave my pubes.]

Yu: 他声称他之所以在外面鬼混的原因是因为我不能满足他的性需 要——而不能满足的原因仅仅是因为我没有剃掉阴毛。

[He claimed that the reason why he fooled around was because I couldn't satisfy his sexual need-and he was not satisfied only due to the fact that I didn't shave my pubes.]

Ai: 我丈夫说, 他出去玩女人, 是因为我不肯剃阴毛, 丕愿在性生活 中满足他。

[My husband said, he went out to womanise, because I wouldn't shave my pubes and wouldn't satisfy him in sex life.]

The two 'wouldn't's in the source text are very important because they emphasise the wife's will. Chen Cangduo translates them into '不 ... 不' [didn't... didn't], which simply conveys a fact but does not cover the will of the wife. Similarly, Yu Rongjun renders into '不能 ... 没有' [couldn't . . . didn't]. ‘不能” [couldn't] implies inability or impossibility; ‘没有' [didn't] expresses the fact, with no reference to the will of the wife. Ai Xiaoming translates into '不肯... 不愿' [wouldn't... wouldn't] to convey the unwillingness of the wife. Her translation is faithful to the source text both in terms of language and feminism. The male translators have not grasped that the context is one of a power play between husband and wife, with the former imposing his will upon the latter and also accusing her of resisting his will, which, in his view ought to be obeyed. It seems unlikely that Chen's and Yu's respective translations are due to their ignorance about the precise meaning of such modal verbs in English. Given that they are both male translators, it seems to provide some evidence that the men's deep-seated patriarchal view could manifest itself unconsciously, or sub-consciously, or even consciously to distort their translation of a feminist text.

9 ST: She asked me why I didn't want to please my husband. I told her I thought it was weird. (10)

Chen: 她问我为何不取悦丈夫。我告诉她说, 我认为那样是很怪异 的。(34)

[She asked me why I didn't please my husband. I told her, I thought that was very weird.] 
Yu: 她问我为什么不愿意满足我的丈夫? 我...告诉她, 我觉得我丈 夫的那种做法很古怪, [...]。

[She asked me why I wouldn't satisfy my husband? I . . told her, I thought that practice of my husband was very weird.]

Ai: 她问我, 为什么你不肯满足你丈夫? 我告诉她, 我觉得丈夫的要 求太古怪, $[\ldots]$ 。

[She asked me, why you wouldn't satisfy your husband? I told her, I thought the request of my husband was too weird.]

In this example, Chen Cangduo is again deficient when he translates 'didn't want to please' as '不取悦' [didn't please]. Without 'want', the message the reader gets from 'didn't please' is that it was the wife's fault for failing to please her husband. This misses the important point that the request of the husband was unreasonable and against the wife's will. Yu Rongjun and Ai Xiaoming use ‘不愿意” / 不肯' [wouldn't] to express 'didn't want', which conveys the source text meaning. It is interesting to note that Yu Rongjun, in this instance, appreciates the feminist significance behind 'didn't want to please', an appreciation he has failed to show in Example 8, where he translates the two 'wouldn't's as 'couldn't' and 'didn't'. In dealing with 'weird', Ai's translation '太古怪' [too weird] expresses a much stronger sense than Chen's translation ‘很怪异的' [very weird] and Yu's translation “很古怪” [very weird] as well as the source text. The word 'too' intimates that the husband's request is too strange to be accepted, and stresses the woman's spirit of rebellion against sexual oppression.

In this example, Chen's translation in the first case ignores the woman's will, though his translation in the second case conveys the source text meaning. Yu Rongjun reproduces the source text meaning in both cases. Ai Xiaoming reproduces the source text meaning in the first case, and her translation in the second case accentuates the weirdness of the husband's request and the wife's strong objection to the request, again revealing her feminist stance.

10 ST: (I felt little when my hair was gone down there, and I couldn't help talking in a baby voice, and) the skin got irritated and even calamine lotion wouldn't help it. (10)

Chen: 那儿的皮肤变得过敏, 甚至润滑剂也没用。(34-35)

[the skin there became allergic and even lubricant wouldn't help it.]

$\mathrm{Yu}$ : 我暴露的肌肤就没了感觉。

[my exposed skin lost feeling.]

$\mathrm{Ai}$ : 那儿的皮肤发炎疼痛, 连抗过敏药膏都没用。

[the skin there was inflamed and painful, and even anti-allergic ointment wouldn't help it. ]

This passage talks about the effect of shaving on the woman's skin. One meaning of 'irritate' is 'to make your skin or a part of your body sore or painful' 


\section{The female body and female sexuality in TVM}

(Hornby 2009: 1081). Thus, 'the skin got irritated' in the source text means the skin is painful. Chen Cangduo mistranslates 'got irritated' as '变得过敏' [became allergic], reducing the pain resulting from the shaving. In Yu's translation '我暴露的肌肤就没了感觉' [my exposed skin lost all sensation], the pain the wife suffered from her shaved vagina is also lost. Ai's translation '发炎疼痛' [inflamed and painful] clearly conveys the wife's suffering from her shaved vagina. This translation also underlines the consequence of or the suffering from the unreasonable request of the husband and shows her sympathy with the wife. This is another example showing the differences between the female and male translators in grasping and conveying women's physical feeling.

11 ST: Then, later, when my husband was pressing against me, I could feel this spiky sharpness sticking into me, my naked puffy vagina. $(10-11)$

Chen: 以后, 当我的丈夫压在我身上时, 我可以感到他那如钉子般的尖 锐东西进入我的身体, 进入我那赤裸、膨胀的阴道。(35)

[Later, when my husband was pressing against me, I could feel his sharp-pointed thing like a nail entering into my body, into my naked puffy vagina.]

Yu: 接着, 他便兴奋地扑在我身上, 不由分说地进入了我的体内, 可 是, 我暴露的阴道却再也没有了热情, [ . . . 。

[Then, he threw himself on me excitedly, and, allowing no arguments, entered into my body; but, my exposed vagina had no enthusiasm any longer, $[\ldots]]$

Ai: 以后, 当我的丈夫压在我身上时, 我可以感到他那如钉子般尖锐 的东西刺入我的身体, 刺入我那赤裸、膨胀的阴道。

[Later, when my husband was pressing against me, I could feel his sharp-pointed thing like a nail sticking into my body, into my naked puffy vagina.]

The verb 'stick' means 'to push sth, usually a sharp object, into sth' (Hornby 2009: 1980, my emphasis), used in the source text to foreground the wife's painful feeling. Chen Cangduo, as well as Yu Rongjun, translates it as '进入' [entering into], which is too mild to convey the piercing pain the wife was suffering. Ai Xiaoming translates 'sticking into' as '刺入' [stick into]. '刺' means 'sting, stab, stick, thrust, piece, prick, puncture' (Hui Yu 2011: 280). '刺入' [sticking into] conveys the exact meaning of the source text and vividly expresses the pain the wife was suffering. The female and male translators' performances here are very similar to those in Examples 9 and 10 in Chapter Four.

\subsection{Translating misogyny}

Misogyny is a kind of emotional abuse against women and even from women themselves, deeply embedded in patriarchal culture and generally invisible. 
Misogyny from women themselves often results from the misogyny from men; after all, women's attitudes towards their own bodies have been constructed on the basis of social or patriarchal norms. Instances of misogyny appear several times in the play, revealing that both men and women may be misogynous to different degrees, wittingly or unwittingly. Ensler's main purpose of writing the work is to prevent sexual violence against women and reverse women's negative attitude towards their bodies so that they can appreciate and gain happiness from their bodies and their sexuality. The following examples show how the translators deal with misogyny.

12 ST: (Down there?) I haven't been down there since 1953. No, it had nothing to do with Eisenhower. (25)

Chen: 自从一九五三年以来, 我就不曾到下面那儿了。不, 这跟艾森豪 (Eisenhower，美国第三十四任总统一一译注)无关。(46)

[I haven't been down there since 1953. No, it had nothing to do with Eisenhower (Eisenhower, the thirty-fourth president of the United States-translator's note)]

Yu： 自从1953年起我就没有碰过下面了。不，这和抗美援朝没有关 系。

[I haven't been down there since 1953. No, it had nothing to do with the War to Resist US Aggression and Aid Korea.]

Ai: 哎吆, 我的天啊, 有多少年我都没再去过下面那儿了。 [Oh, my heaven! For many years I haven't been down there.]

Examples 12 and 13 come from a monologue called 'The Flood', which is based on the vagina interviews of a group of women between the ages of sixty-five and seventy-five. Ensler feels these interviews are the most poignant of all, because most of the women in this age group 'had very little conscious relationship to their vaginas', not to mention having ever enjoyed an orgasm (Ensler 2001: 23). This monologue illustrates that 'patriarchal culture has established distance between women and their vaginas' (Hall 2005: 104). This example shows that the interviewee was greatly surprised by the vagina question 'Down there?', and had been indifferent to her vagina for many years, i.e. from 1953 until the time she was interviewed. For her, 1953 is an important year, in which an incident made her shut herself off from her vagina (see Example 13). The interviewee laughed at herself for her indifference to her vagina for too long by referring to Eisenhower, the thirty-fourth president of the United States (19531961), because coincidently Eisenhower started his presidency in 1953. This joke should be easily understood by English speakers, especially in America.

Chen Cangduo transliterates the name 'Eisenhower', followed by a note in parentheses to explain who Eisenhower is. This translation can hardly achieve the same effect for a Chinese audience. Yu Rongjun turns 'Eisenhower' into ‘抗美援朝' [the War to Resist US Aggression and Aid Korea]. It was Eisenhower 
who obtained a truce in Korea in 1953. Many Chinese people from the Mainland know or even remember the historical event in 1953 when the Chinese People's Liberation Army helped the North Korean people resist US aggression. This localised or domesticated translation reproduces the humour of the source text and can achieve a better reception in the Mainland. Chen Cangduo is a professor from Taiwan. This localising could not and would not have occurred to him for political reasons as any reference to such an event would not be well received by his readers in Taiwan. Both Chen Cangduo and Yu Rongjun have sought to retain the original interviewee's sense of humour and ironic empowerment.

In Ai's translation, '1953' and 'Eisenhower' are gone. She focuses on the fact that the interviewee had ignored her vagina for many years, and felt surprised and uneasy with the topic. Since not every Chinese person can quickly identify the connection between '1953' and 'Eisenhower', or may not even know who Eisenhower is, the humorous effect is not that outstanding in the Chinese context. Thus in her translation, 'since 1953' becomes ‘有多少年' [for many years] and 'Eisenhower' is removed. And, she adds '䒝哟, 我的天啊' [Oh, my heaven], a very common feminine way to express surprise, which not only conveys the surprise of the interviewee and highlights the indifference of the woman towards her own body, but also gives a taste of humour. The lost humour due to the removal of 'Eisenhower' is compensated here.

13 ST: but he said, Andy said, that smelled like sour milk and it was staining his car seat. (27)

Chen: 但是, 他却说, 安迪却说, 那味道像是酸牛奶, 玷污他的车座。 (48)

[but, but he said, but Andy said, that smell was like sour milk, it was smearing his car seat.]

Yu: 他说那就像一种酸奶。 [...]因为我沾污了他的跑车。 [he said that was like a kind of yoghurt. [...] because I dirtied his roadster.]

Ai: 安迪却说, 你怎么像......馊了的牛奶 (夸张一点, 做动作)。 [But Andy said, how come you are like... sour milk (be exaggerative, make a motion).]

'The flood' monologue describes a mishap a woman experienced that led to her shutting herself off from the 'messy, smelly, and mishap-laden world of the vagina' (Hammers 2006: 228). In her date with a young man, Andy, when she was young, her sexual excitement following an unexpected kiss from Andy led to what she called a 'flood'. This passage shows Andy's reaction to the accidental flood, which 'shamed the woman into distancing herself from her vagina and her experience of sexual pleasure' (Hammers 2006: 228). The translations of 'sour milk' deserve attention. The expression 'sour milk' refers to milk that has 
'an unpleasant taste or smell because it is not fresh' (Hornby 2009: 1923), and is used in the source text to show Andy's dislike of the girl's flood. It is Andy's dislike that causes the girl to dislike herself in later life. That is to say, women's views of themselves and their sexuality are much influenced by a patriarchal point of view. Chen Cangduo translates it as '酸牛奶', which refers to 'sour milk' in Taiwan but would be understood as 'yoghurt' in the Mainland, hence producing different effects to Chinese readers from different places. Yu Rongjun translates it as '酸奶' [yoghurt], which is more expensive than fresh milk in the Mainland, containing no negative meaning at all, and hence a wrong translation of the source text meaning. Ai Xiaoming translates it as '舅了的牛奶' [sour milk], conveying the same meaning as the source text. The ellipsis she adds before ‘舅了的牛奶' [sour milk] helps convey Andy's distance and dislike, and the note in brackets she adds after “舅了的牛奶” tells the performer how to act out the misogyny. All these produce a dramatic and humorous effect.

As can be seen in the examples already discussed, addition is an important strategy for Ai Xiaoming. In her translation, Ai Xiaoming adds a monologue '干涸的河流' [Dry River], which is completely a Chinese story, but in essence similar to 'The Flood'. It tells the experience of a modern Chinese girl in a city, the story of how her vagina became dry. Her menarche at eleven was a nightmare for her. She was raped by a company boss in the summer before she went to university that upset her lest she became pregnant. In her first love, her boyfriend found that she was not a virgin and deserted her. Since then, her vagina remained dry while making love to other men. Stories of Chinese women's frigidity are said to have resonated especially with women in their forties and fifties who were brought up in closed and conservative social conventions (Anonymous 2005b).

14 ST: she yells at me and says never to let anyone touch me down there again. (78)

Chen: 她就对我大声说, 永远不要再让任何人触碰我下面那个地 方。(81)

[She said loudly to me, never let anyone touch me down there again.]

Yu: 可是妈妈却对我怒吼着, 要我以后再也不要让任何人碰我那里。 [But mother roared at me, asked me not to let anyone touch me there again.]

Ai：她冲我大声怒吼, 她说: 永远别让男人再碰你那儿。

[She roared at me loudly, she said: don't let man touch you there again forever.]

This is an example from 'The Little Coochi Snorcher That Could'. The example is about a 7-year-old girl, whom a 10-year-old boy gets angry at and punches with all his might between her legs. She limps home and cannot pee. Her mother 


\section{The female body and female sexuality in TVM}

asks her what was wrong with her coochi snorcher (i.e. vagina). When she hears the story, she yells at the girl. The word 'anyone' in the source text is ambiguous as to gender identity, although we may infer that her mother meant 'any man'. In her translation, Ai Xiaoming makes it explicit that the little girl should not allow any '男人' [man] to touch her, because it will cause disgrace and harm to her. Doing so, Ai Xiaoming foregrounds the irritation and deep worry of the mother by the incident, and the serious result of being touched by a man. This, to some extent, reflects gender imbalance in society, and women's inferior position in sexually-related matters. It is disgraceful if a young girl were to be touched by a man, but the society does not impose the same restriction upon a man, though a man may also suffer from sexual harassment. Ai Xiaoming makes the gender ('man') explicit and thus adds to the feminist charge. Chen Cangduo and Yu Rongjun use the same word '任何人' [anyone] to represent the English word. Why did not Ensler herself make the feminist charge explicit as she, more than anybody else, ought to make the point obvious and not retreat into imprecision at such a critical moment? But this is not a matter that directly concerns this research. However, it remains correct to say that Ai Xiaoming has been more sensitive in this context, and embodies a feminist stance.

\subsection{Summary}

TVM is a very different type of text from TSS, and a lot more strategies are found in the translation examples. To be exact, in the fourteen examples analysed above, as many as eleven translation strategies are identified: repetition, attenuation, amplification, omission, addition, bilingual translation, zero translation, semantic translation, literal translation, adaptation, and localising (or domestication). Table 5.1 is a summary of the number of times the strategies are used in each translation.

The contrast between 'woman translation' and 'man translation' found in Chapter Four does not seem that clear here in terms of word choices. Here

Table 5.1 Number of times the strategies are used (TVM, Examples 1-14, 18 cases)

\begin{tabular}{lccc}
\hline Strategies & Chen (No. of times) & $\Upsilon$ (No. of times) & Ai (No. of times) \\
\hline Repetition & 8 & 6 & 7 \\
Attenuation & 4 & 4 & - \\
Amplification & - & 2 & 1 \\
Literal translation & 2 & - & - \\
Semantic translation & - & - & 5 \\
Bilingual translation & 4 & 1 & - \\
Zero translation & 1 & 1 & - \\
Omission & 0 & 1 & 4 \\
Addition & 3 & 1 & 1 \\
Adaptation & - & 3 & 1 \\
Localising & - & 1 & 22 \\
Total & 22 & 20 & \\
\hline
\end{tabular}


'cross resemblance' between the three translations is sometimes seen. Chen and Yu choose the same or similar words or phrases in Examples 11 and 14; Chen and $\mathrm{Ai}$, in Examples 6(1) and 7(1); and $\mathrm{Yu}$ and $\mathrm{Ai}$, in Example 9. However, differences in choices of strategies produce different effects, though repetition is used equally in the three translations, a sign that the translators mainly keep close to the source text. Attenuation occurs four times in each of the translations by the male translators, who either disclose a patriarchal view, fail to convey or reduce the feminist message, or fail to convey the harm to women (see Chen, Examples 8, 9, and 10; Yu, Examples 8 and 13). Literal translation occurs in Chen's translation only, which either loses the humour of the source text or makes little sense (see Examples 4 and $7(2)$ ). Bilingual translation and zero translation are used by the male translators only, which Ai Xiaoming does not use at all throughout her translation. The bilingual representation and zero translation require bilingual audiences, to some extent reflecting the elitist feature of feminist texts, even in such a popular play. These strategies do not fit the goal of Ai Xiaoming's translation and production. As a feminist activist and professor, Ai Xiaoming seems to pay much attention to reception so that her translation and production can reach wide audiences and be instrumental in improving women's status in society. That is also the reason why omission and addition are more used in Ai's translation. The added translator's notes in Chen's translation can also help readers understand the text, as in Examples 1, 3 , and 4. A feminist stance or interventions and sympathy for women are found in many examples of Ai's translation (such as Examples 6(2), 7(2), 9(2), 10, 12, and 14). A few strategies Ai Xiaoming uses resemble Western feminist translation strategies in spirit, such as her semantic translation in Examples 4, 7(2), 9(2), 12, and 14, localising in Example 4, and addition in Examples 5 and 13. A feminist stance is also found in some examples of Yu's translation (such as Examples 1, 6(2), 7(1), and 12), but are not outstanding in Chen's translation. Mistranslations are found in Chen's translation (as in Example 7(2)) and Yu's translation (as in Example 13). The findings here to a certain degree echo the findings in Chapter Four.

\section{Bibliography}

Ai, Xiaoming 艾小明 (trans.) (2003) 阴道独白 [The Vagina Monologues], http://smileinwind. bokee.com/2440712.html (last accessed on 31 March 2006).

Anonymous (2005a) ‘专访《阴道独白》导演蓝贝芝' [A Special Interview with Lan Beizhi, Director of The Vagina Monologues], http://bloguide.ettoday.com/mathink/textview. php? file $=9836$ (last accessed on 4 July 2008).

— (2005b) '戏剧一阴道独白' [Drama-The Vagina Monologues], http://myweb. ncku.edu.tw/ kailing/generaled/g\&l_s05/activity.htm, (last accessed on 4 July 2008).

Beauvoir, Simone de (1972) The Second Sex, translated and edited by H. M. Parshley, Harmondsworth: Penguin.

Bell, Susan E. and Susan M. Reverby (2005) 'Vagina Politics: Tensions and Possibilities in The Vagina Monologues', Women's Studies International Forum 28: 430-444. 
Belsey, Catherine and Jane Moore (eds) (1989/1997) The Feminist Reader: Essays in Gender and the Politics of Literary Criticism (2nd edition), Malden, MA: Blackwell Publishers, 104-116.

Braun, Virginia and Eve Ensler (1999) 'Virginia Braun in Conversation with Eve Ensler: Public Talk about "Private Parts"', Feminism \& Psychology 9(4): 515-522.

Burger, Richard (2012) Behind the Red Door: Sex in China, Hong Kong: Earnshaw Books. Cao, Shuying 曹疏影 (2007) “阴道的复数“独白”——记《阴道独白》在中国” [Plural 'Monologue' of Vagina: The Vagina Monologues in China], http://genders.zsu.edu.cn/ News/1768-Content-1768.html (last accessed on 7 June 2010).

Chen, Cangduo 陈苍多 (trans.) (2000) 阴道独语 [The Vagina Monologues], Taibei: 新雨出版社 [Xinyu Publishing House].

Cheng, Sea Ling (2004) 'Vagina Dialogues?', International Feminist Journal of Politics 6(2): 326-334.

Conboy, Katie, Nadia Medina and Sarah Stanbury (eds) (1997) Writing on the Body: Female Embodiment and Feminist Theory, New York: Columbia University Press.

Dodson, Betty (2001) 'Vagina Monologues \& V-Day', www.bettydodson.com/vaginano. htm (last accessed on 12 August 2008).

Ensler, Eve (1998) The Vagina Monologues, New York: Villard.

— (2001) The Vagina Monologues: The V-Day Edition, New York: Villard.

Farrer, J. (2002) Opening Up: Youth Sex Culture and Market Reform in Shanghai, Chicago: University of Chicago Press.

Flotow, Luise von (1997) Translation and Gender: Translating in the 'Era of Feminism', Manchester: St Jerome.

Genette, Gérard (1997) Paratexts: Thresholds of Interpretation, Cambridge: CUP, 1-2.

Hall, Kim Q. (2005) 'Queerness, Disability, and The Vagina Monologues', Hypatia 20(1): 99-119.

Hammers, Michele L. (2006) 'Talking About "Down There": The Politics of Publicizing the Female Body through The Vagina Monologues', Women's Studies in Communication 29(2): 220-243.

Hornby, A. S. (ed.) (2009) 牛津高级英汉双词典 (第7版) [Oxford Advanced Learner's English-Chinese Dictionary] (7th edition), translated by Wang Yuzhang 王玉章, Zhao Cuilian 赵翠莲, Zou Xiaoling 邹晓玲, Beijing: 商务印书馆 [The Commercial Press], Oxford University Press.

Hui, Yu 惠宇 (ed.) (2011) 新世纪汉英大词典 [A New Century Chinese-English Dictionary], Beijing: 外语教学与研究出版社 [Foreign Language Teaching and Research Press].

Jones, Ann Rosalind (1981) 'Writing the Body: Toward an Understanding of L'écriture féminine,' in Elaine Showalter (ed.) The New Feminist Criticism: Essays on Women, Literature, and Theory, London: Virago, 361-377.

Lin, Meilian (2010) 'Like a Virgin', Global Times, 17 June 2010, http://special. globaltimes.cn/2010-06/542926.html (last accessed on 21 June 2010).

Liu, Weiming 刘炜苔 (2004) '日常生活中的女性主义' [Feminism in Daily Life], http:// she.563.net/article/2004/2004-11-23/33759.html and www.lalabar.com/news/Read News.asp? NewsID=209 (last accessed on 6 July 2008).

McClintock, Anne, Aamir Mufti and Ella Shohat (eds) (1997) Dangerous Liaisons: Gender, Nation, and Postcolonial Perspectives, Minneapolis, London: University of Minnesota Press, 255-411.

McElroy, Wendy (2002) 'Take Back Valentine's Day!' www.ifeminists.com/introduction/ editorials/2002/0212.html (last accessed on 10 August 2008). 
Mills, Sara and Lynne Pearce (1996) Feminist Readings/Feminists Reading (2nd edition), London: Prentice Hall.

Moi, Toril (ed.) (1985) Sexual/Textual Politics: Feminist Literary Theory, London and New York: Methuen.

- (1999/2001) What is a Woman? And Other Essays, Oxford: Oxford University Press.

Price, Janet and Margrit Shildrick (eds) (1999) Feminist Theory and the Body: A Reader, New York: Routledge.

Sigley, Gary (2006) 'Sex, Politics and the Policing of Virtue in the People's Republic of China', in Elaine Jeffreys (ed.) Sex and Sexuality in China, London and New York: Routledge, 43-61.

Steinem, Gloria (2001) 'Foreword', in Eve Ensler, The Vagina Monologues: The V-Day Edition, New York: Villard, ix-xix.

Yu, Rongjun 喻荣军 (trans.) (2003) 阴道独白 [The Vagina Monologues], http://bbs. sachina.pku.edu.cn/archiver/tid-3681.html (last accessed on 27 December 2006). 


\section{Translating lesbianism in The Second Sex and The Vagina Monologues}

Sexuality has been much emphasised by radical feminists because it relates to oppression as well as liberation, and concerns women of different sexual orientations (Ai Xiaoming 2004). Lesbianism has played an important part in feminism, because to some extent it represents women's sexual autonomy and hence freedom from patriarchal sexual oppression. Beauvoir takes lesbianism as one of the ways to overcome women's erotic passivity (Fuchs 1980: 310), 'an authentic alternative for women in a sexist society that offers and legitimates only inauthentic alternatives' (Simons and Benjamin 1979/1999: 8). Wittig claims that 'lesbianism provides for the moment the only social form' in which women can live freely, and lesbianism is the only concept that is 'beyond the categories of sex (women and men)' because a lesbian is not a woman economically, politically and ideologically; therefore by refusing to become or to stay heterosexual, lesbians escape woman's social relationship with man, a relationship which has been called servitude and implies personal, physical, and economic obligation (Wittig 1997: 316). The female body and female sexuality discussed in Chapters Four and Five concern heterosexual relations. This chapter focuses on the Chinese translations of lesbianism in The Second Sex (TSS) and The Vagina Monologues (TVM).

Homosexuality is regarded as abnormal and unacceptable by most Chinese people, and is typically represented in the Chinese media as an 'abnormality' or a 'perversion' (Ho 2008: 496). There are many pejorative/derogatory Chinese terms for homosexuals, such as “二尾子' (a person who is neither a man nor a woman), ‘兔子' (rabbit, an offensive term for homosexual), and '屁精' (male prostitute, an offensive term for gay). The Chinese term '同性恋' [homosexuality] 'carries a social stigma' (Ho 2008: 496). Consequently, homosexuals suffer much discrimination and usually live in depression and pain ( $\mathrm{Li}$ Yinhe and Wang Xiaobo 1992, Liu Dalin and Lu Longguang 2004: 62-71, Wen Jianguo and Luo Lina 2009). Even scholars working on homosexuality attract attacks, such as Li Yinhe, the first scholar to study sexual subculture (i.e. subculture concerning homosexuality, sadomasochism and sex workers, etc.) in China. Her speeches on homosexual rights often incur invective, as can be seen in netizens' posts in her blog. Research works on homosexuality can be difficult to have published. Li Yinhe and Wang Xiaobo could not find a Mainland publisher for their book 
他们的世界——中国男同性恋群落透视 [Their World-An Investigation into the Chinese Gay Community], based on their research on gay life in China from 1989 to 1991. The book was first published in Hong Kong in 1992 and later in the Mainland. Similarly, the book 中国同性恋研究 [A Study on Homosexuality in China] by Liu Dalin and Lu Longguang was planned for 1994, but was not published until 2004. In that book, the last chapter is about '同性恋的防治' [the prevention and treatment of homosexuality], treating homosexuality as a disease.

In the 2009 Research Report on the Living Conditions of Homosexuals in China, there is a story about a university student who was rejected for blood donation due to the student's homosexuality, as given on the blood donation health registration form (Wen Jianguo and Luo Lina 2009). In November 2010, two pieces of news attracted the public attention. One was that Fei Xiang, a handsome popular singer, was exposed as being gay, which caused a big surprise and sensation (Xin Feng 2010a). The other was that Fan Bingbing, a female film star and a charming actress, French-kissed a female director when she received the movie queen cup of the twenty-third Tokyo International Movie Festival. This was commented upon as being shocking, disgusting and unbearable, and she was suspected of being a lesbian (Anonymous 2010, Ma Shanji 2010, Xin Feng 2010b). Under such circumstances, Chinese translations of lesbianism in the two texts deserve a separate discussion. The ways the translators treat the lesbian materials might be especially revealing in terms of the representation of Western feminism.

\subsection{Lesbianism in the Chinese translations of The Second Sex}

In Book II of TSS, Beauvoir devotes a special chapter entitled 'The Lesbian' to a discussion of lesbian formation. Actually, lesbian experiences and feelings are not confined to this chapter. Lesbianism occurs from the first chapter 'Childhood', through 'The Young Girl', to 'Sexual Initiation'. Beauvoir's lovers included both women and men (Simons 1999: 143). Inevitably, Beauvoir has been regarded as a lesbian although she never said she was (Beauvoir 1975: 197, Altman 2007: 211). Her analysis of lesbian formation to some degree reflects her understanding of lesbianism from her own intimate relations with some female friends. This section scrutinises the Chinese translations of the lesbian chapter in TSS to see how the Chinese translators deal with the lesbian content and discuss the translation effects from a feminist perspective. In Chapter Four, four Chinese translations are examined. In this section, three Chinese translations are analysed: one by Sang Zhuying and Nan Shan (1986), one by Tao Tiezhu (1998), and the other by Li Qiang (2004). The lesbian chapter is cut in the translation by Wang Youqin and Qiu Xichun et al., and hence is not included here. In the abridged translation by Li Qiang, a large proportion of description, analysis and illustrations of women's life experiences are cut. Consequently, most of the lesbian chapter is cut out with only six pages left, while the lesbian chapter is twenty-two pages long in the other two translations. As a result, Li's translation is absent in six out of the eleven examples discussed below. 
I ST: Only the lesbian could have as rich a libido as that of the male, and she would therefore represent a 'superior' feminine type. (427)

$\mathrm{S} / \mathrm{N}$ : 唯有女同性恋才能有男性一般的强盛性欲, 如此她可代表女性之 间的“优越型”。(176)

[Only a lesbian can have the same strong sexual desire as a man does, thus she may represent the 'superior' type among women.]

Tao: 唯有女性同性恋才可以有和男人一样丰富的利比多, 因而她将代 表一种“优越的”女性类型。(464)

[Only a lesbian can have the same rich libido as a man does, hence she will represent a 'superior' type of women.]

Li: $\quad$ (cut) $(172)$

The word 'libido' in the source text refers to 'sexual desire or impulse' which remains the same in the translation by $\mathrm{S} / \mathrm{N}$. Tao transliterates it, retaining its pronunciation. It is true that 'libido' is mostly transliterated in Chinese as in the Chinese translations of Freud's works (see Gao Juefu 1984/2004: 2, Zhou Quan et al. 2000/2007: 4) and in some English-Chinese and Chinese-English dictionaries (see Lu Gusun 1989/2003: 1885, Wu Guanghua 1993/2002: 1027 and 1998: 1347, Ge Chuangui et al. 2000/2002: 745, Thompson and Chen Kai 2003: 1169). It is also true that the meaning is not widely known to most general readers. Even if some readers have heard of this pronunciation, they may not necessarily know the exact meaning and may not immediately understand the translation. This may interrupt the reading flow. The translation by the female translators makes unobstructed reading for both the general reader and the academic reader. In the source text, 'would' refers to a possibility rather than the past tense of 'will'. S/N translate it into '可' [may] which retains the meaning of possibility although the Chinese character '可' does not have inflections indicating tense. Tao misunderstands 'would' as the past tense of 'will' and mistranslates it into '将' [will], turning a possibility into a fact. In this example, $\mathrm{S} / \mathrm{N}$ reproduce the source text meaning in both cases. Tao transliterates to convey the sound in the first case and translates the dictionary meaning in the second case, which changes the source text meaning.

2 ST: (certain women decline passivity,) whereas others choose feminine arms in which to abandon themselves passively. (429)

$\mathrm{S} / \mathrm{N}$ ：另一些女人则选择女性之怀抱来被动地放纵自己。(178) [while others choose female arms in which to indulge themselves passively.]

Tao: 而另一些女人则愿意用女性的武器被动地放纵自己。(466) [while others are willing to use female weapons in which to indulge themselves passively.] 
$\mathrm{Li}$ ：而另外一些女性则甘愿用女人的本钱来被动地放纵自己。(173) [while others are willing to use female assets in which to indulge themselves passively.]

In this example, 'feminine arms' refers to lesbian intimate or sexual relations and bodily contact. S/N's '女性之怀抱' [female arms] conveys the source text meaning. Tao and Li mistranslate 'feminine arms' as '女性的武器' [female weapons] and '女人的本钱' [female assets] respectively. The translations by the two men reflect their misunderstanding of the source text, or to be exact, the word of 'arms'. '武器' [weapon] is one of the dictionary meanings of 'arm'. 'Female weapons' in the Chinese language is usually used in a context where women make use of their sexual attractiveness and sex in exchange for certain favours from men, which is not the source text meaning. Li's 'female assets' is another phrase to express the same idea. The two expressions, in any case, are closely related to heterosexual relationships. Even if they can be used to describe sexual attraction between lesbians, it is not what the source text is about (i.e. some women choose to lose themselves passively in feminine arms). The understanding of lesbianism on the part of the male translators is virtually nonexistent in this passage.

3 ST: most little girls feel the same sense of outrage and the same desperation when they learn that the chance conformation of their bodies renders their tastes and aspirations blameworthy. (430)

$\mathrm{S} / \mathrm{N}$ : 多年 [ sic] 的小女孩, 在得知她们生来之性别使她们的爱好与抱负 变得不正当时, 都会感到同样的愤怒与绝望。(179)

[Little girls of many years [sic] will feel the same anger and despair when they know that their sex by birth makes their hobbies and ambitions improper.]

Tao：许多小女孩当认识到对她们身体的偶然适应将使她们的爱好与抱 负变得有罪时, 也会同样感到愤怒和绝望。(468)

[Many little girls will also feel the same anger and despair when they are aware that chance adaptation to their bodies will make their hobbies and ambitions guilty.]

Li: $\quad$ (cut) $(173)$

In this passage, 'the chance conformation of their bodies' refers to 'anatomy or structure of the body formed by accident'. Beauvoir points out in TSS that the lives of women should not be determined by the fact that their anatomy is different from that of men. It is merely an accident that one is born into the female sex. It is the patriarchal society that relegates women to the inferior sex. There is nothing wrong with their biological sex. S/N translate it as '生来之性别' [sex at birth], conveying the sense of the source text, while Tao translates as '对她 们身体的偶然适应' [chance adaptation to their bodies]. This seemingly literal 
translation makes little sense in Chinese, showing that Tao does not understand the source text. Incidentally, '多年' [many years] in S/N's translation is a typographical error. It should be '多数' [majority, or many].

4 ST: the 'garçon manqué' stubbornly retains her boyishness. (431)

$\mathrm{S} / \mathrm{N}$ : 这位“顾皮姑娘”就固执地保留她的男孩子气。(180)

[this 'tomboy' stubbornly retains her boyishness.]

Tao: 'gracon [sic] manqué' [男孩子气的女孩子] 就会顽固保持她的男 孩子气质。(468)

['gracon [sic] manqué' [boyish girl] will stubbornly retain her boyishness.]

Li: $\quad$ (cut) $(173)$

5 ST: Because the partners are homologous, basically alike, all kinds of combinations, transpositions, exchanges, comédies are possible. (441)

$\mathrm{S} / \mathrm{N}$ : 由于双方是对等的, 基本上是相象的, 所以各种组合、转移、 交替、喜剧, 都是可能的。(190-1)

[Because both sides are equal, basically alike, all kinds of combinations, transpositions, alternations, comedies are possible.]

Tao: 由于两个性伙伴是对等的、基本相似的, 种种结合、易位、交替 和 comédies [可笑的举动] 都可能发生。(478)

[Because the two sexual partners are equal, basically alike, all kinds of combinations, transpositions, alternations, comédies [funny behaviours] are possible.]

Li: $\quad$ (cut) (173)

Examples 4 and 5 each contain a French term. The expression 'garçon manqué' means 'tomboy', and 'comédies' refers to the affectation, play-acting, or performing of the partners. S/N's translation '顽皮姑娘' [tomboy] reproduces the meaning of the French expression 'garçon manqué'. S/N render 'comédies' into ‘喜剧' [comedy], conveying the performativity of lesbian identity and implying that the partners' play-acting is amusing. The Chinese term “顽皮姑娘” [tomboy] has the implication of 'active' and 'lovely' and the term '喜剧' [comedy] implies 'interesting' and 'fun', both positive, showing a kind of sympathy with the lesbian relationship. Tao adopts bilingual translation in rendering the two French terms, keeping the French terms and explaining the meaning in Chinese in square brackets, just as Chen Cangduo does in translating the vagina terms (discussed in Chapter Five). The French terms in the English source text may not appear very strange or cause reading difficulty to English readers due to the similarities between the two languages. A good example is 'comédies' and 'comedy'. In practice, 'comedy' has different implications to and produces different associations 
among Chinese and Euro-American readers. This is an interesting topic but falls outside the scope of this study and is not discussed here. In the Chinese context, they may make sense to some bilingual readers, making them aware of the source language, but are probably a burden to many general readers.

6 ST: Though she can employ artificial means for deflowering and possessing her loved one, she is none the less a castrate [...]. (434)

$S / N$ : 但虽然她能运用人造工具翟入而占有她的爱人, 她到底缺乏男性 之性能, [...]。(183)

[But although she can use artificial tools to penetrate and possess her lover, she after all lacks masculine sexual function, [...].]

Tao: 虽然她能够以人为方式夺取她爱人的贞操并将她占有, 但她仍然 是个菴人, [...]。(471)

[Although she can dispossess the virtue of her lover and possess her in an artificial way, she is still a castrated person, [...].]

$\mathrm{Li}$ 然而就算她可以用人为手段夺走她情人的贞操而占有她, 也改变 不了她是个菴人的事实, [...]。(175)

[However even if she can dispossess the virtue of her lover and possess her in an artificial way, she cannot change the fact that she is a castrated person, [...].]

This passage embodies Beauvoir's understanding of the potential sexual embarrassment in lesbianism due to the lack of a male sexual organ. In the source text, 'employ artificial means' tells how a masculine lesbian can deflower her loved one. The word 'means' has different meanings. It can refer to either a method or an instrument used to obtain a result or achieve an end. S/N translate it into '运用人造工具' [use artificial tools], which makes the meaning of the source text very explicit, while Tao and Li translate it as '以人为方式/手段' [in an artificial way], which expresses one of the dictionary meanings of 'means', making their translations ambiguous. More such specious or wrong expressions in their translations of the lesbian chapter can be found, especially in Tao's translation (see Tao/Li: 468/173 (cut), 471/175, 474/175 (Example 8), $475 / 175$ (cut), 477/176 (Example 9), and 482/176 (cut)).

The noun 'castrate' refers to the sexual inability of a masculine lesbian to satisfy her lover as she does not have a male sexual organ. It draws attention to lesbians' deep unhappiness and frustration, which are as profound as that endured by male castrates when faced with the fact that they can no longer realise their masculine potential. The translation by $S / \mathrm{N}$ simply expresses the fact that a castrate is a person who '缺乏男性之性能' [lacks masculine sexual function], avoiding any disparaging connotation the term 'a castrate' may have and again showing a kind of sympathy with lesbianism. Tao and $\mathrm{Li}$ both translate it into '阉人' [castrated person], a term with strong derogative connotation in Chinese culture. Castrates, such as eunuchs, were traditionally even more humiliated, 
more pitilessly despised than such persons were in English culture. It now refers to not only a man who has been castrated and is incapable of reproduction, but also a sexually repressed person. It often implies that such a man is not a man, or even neither man nor woman. It is a hurtful term when used against a person, usually a man. It is seldom linked to a woman.

In this example, $\mathrm{S} / \mathrm{N}$ reproduce the source text meaning explicitly in the first case and render it in a neutral way, reducing the negative implication of the term and showing their sympathy with lesbianism. Tao and Li make a literal translation in the first case and use a strong negative Chinese term in the second case, revealing their vague understanding of lesbian sexuality and conscious or unconscious negative attitude towards lesbianism.

7 ST: She is unfulfilled as a woman, impotent as a man, [...]. (434)

$\mathrm{S} / \mathrm{N}$ : 就女人身份而言, 她得不到满足与报偿, 就男人身份而言, 她没 有性能力, [ . . . 。 (183)

[As a woman, she gains no satisfaction and reward; and as a man, she has no sexual capacity, [...].]

Tao: 她作为一个女人是未实现的, 作为一个男人又是无性能力 的, [...]。(471)

[As a woman, she is unrealised, and as a man, she has no sexual capacity, $[\ldots]$.

$\mathrm{Li}$ 她不能以一个女人的身份也不能真正作为一个男人而实现其性行 为, $[\ldots]$ 。 $(175)$

[She cannot realise her sexual act either as a woman or as a real $\operatorname{man},[\ldots]$.

Example 7 explains that, being deprived of the virile organ, a lesbian may suffer acutely: she can neither gain sexual satisfaction from same-sex love as a woman, nor can she satisfy her loved one as a man. The adjective 'unfulfilled' means '(of a need, wish, etc.) that has not been satisfied or achieved'. Here it refers to sexual dissatisfaction. S/N's translation '得不到满足与报偿' [gains no satisfaction and reward] reflects this sense. Tao translates it literally as '未实现的' [unrealised], which conveys one of the dictionary meanings of 'unfulfilled', but makes little sense in the Chinese sentence. Li's translation '不能 ... 实现其性行为' [cannot realise her sexual act] is another literal translation of 'unfulfilled', which does not convey the exact source text meaning, as 'realise her sexual act' refers to the action, the process, while 'fulfil' refers to the result. The men's translations here again show their difficulty in understanding lesbian sexuality.

8 ST: (In the first case their relation often verges upon homosexuality:) they sleep together, caress each other, or indulge in breast kisses; the young girl will later seek the same happiness in other arms. (437) 
$\mathrm{S} / \mathrm{N}$ : 她们一同睡觉, 相互爱抚, 或互吻胸部; 此少女以后将在别的怀 抱中寻索同样的快乐。(186)

[they sleep together, caress each other, or kiss each other's breasts; the young girl will later seek the same happiness in other arms.]

Tao: 她们睡在一起, 相互抗摸, 或很喜欢轻触乳房。少女后来在别人 的怀抱里也会有这种快活。(474)

[they sleep together, caress each other, or enjoy very much lightly touching breasts; the young girl will later have the same happiness in other arms.]

$\mathrm{Li}$ : 她们在一起睡觉, 相互爱抚, 或着 [sic] 喜欢轻轻地触摸乳房, 这 样的少女未来躺在别人怀抱中也会感到这种快感。(175)

[they sleep together, caress each other, or enjoy lightly touching breasts; such a young girl will in the future feel the same happiness in other arms.]

In 'The Lesbian' chapter, the importance of the relationship a homosexual woman had earlier with her mother is discussed, and two cases are mentioned in which the adolescent girl has difficulty escaping the influence of her mother. The selected passage in Example 8 is the first case: if she has been overly protected by an anxious mother, their relations often border on homosexuality. What happens between the daughter and mother (caressing each other or kissing each other's breasts) influences the girl's sexuality in her future life. Since the girl is used to and enjoys the happiness from the caresses and kisses, she will be desirous of these in her future sexuality. S/N's translation in the example expresses the same meaning with the source text. Tao and Li translate 'kisses' as 'lightly touching', which is a different act from 'kiss' and produces different physical feelings. Tao and Li translate 'seek' as 'have' or 'feel', again deviating from the source text meaning. The word 'seek' implies 'try to obtain' while 'have' and 'feel' entail no effort (Hornby 2009: 1805). Their translations dramatically dilute the sexual pleasure and the resultant desire in the girl. These mistranslations are difficult to understand as the passage is not linguistically difficult at all. But one can speculate. As men, Tao and Li might be ignorant about the different degrees of sexual pleasure involved in 'lightly touching breasts' and 'kissing the breasts'. Gender identity appears to have played some role here.

9 ST: If she is passive and sensual, she will not be repelled by the caresses of a woman friend, since she will in this case have only to give way and let herself be gratified. (440)

$\mathrm{S} / \mathrm{N}$ : 如果她被动而因感, 她将不厌恶女朋友的爱抚, 因为在此情形下 她只需给出去, 并让自己获得满足。(189)

[If she is passive and sexy, she will not dislike the caresses of a girlfriend, because, under such circumstances, she only needs to give (herself) away, and let herself be satisfied.] 
Tao: 如果她是被动的、淫荡的, 就不会讨厌女友的抚摸, 因为她这时 只能退却, 让自己得到满足。(477)

[If she is passive, lewd, she will not dislike the caresses of a girlfriend, because at this time she can only fall back, let herself be satisfied.]

Li: $\quad$ (cut) (176)

The adjective 'sensual' in the source text suggests 'an interest in physical pleasure, especially sexual pleasure' (Hornby 2009: 1816). S/N translate 'sensual' as '肉感', which refers to a woman being 'voluptuous and sexy' (Hui Yu 2011: 1370), implicitly conveying the source text meaning. This example again shows that the women translators are more conservative in expressing sexuality and consciously or unconsciously attenuate the sexual implication (as discussed in Example 3 in Chapter Four). Tao translates into '淫荡的', meaning 'loose in morals, lascivious, lewd' (Hui Yu 2011: 1940). It contains very strong negative connotations in Chinese culture, as expressed in the Chinese saying: '万恶淫 为首' [Lewdness is the worst of all vices]. It reflects a kind of moral judgement, and somewhat reveals Tao's attitude towards lesbian sexuality.

10 ST: If she is active and fiery, she will seem 'androgynous', [...]. (440)

$\mathrm{S} / \mathrm{N}$ : 如果她主动而狂热, 她将象个“两性人”, [...]。(189)

[If she is active and fanatic, she will be like 'a bisexual person', $[\ldots]$.

Tao: 如果她是主动的、狂热的, 她就会像个“阴阳人”似的, [...]。 (477)

[If she is active, fanatic, she will be like 'an epicene person', $[\ldots]$.

Li: $\quad$ (cut) (176)

The word 'androgynous' means 'having both male and female characteristics; looking neither strongly male nor strongly female' (Hornby 2009: 66). S/N translate it into '两性人' [a bisexual person]. In biology, 'bisexual' means 'having both male and female sexual organs', the same as 'androgynous' (Hornby 2009: 186). Tao's translation '阴阳人' [an epicene person] also refers to a person that has both male and female sexual organs or characteristics. Hence, ‘两性人' [a bisexual person] and '阴阳人' [an epicene person] share the same meaning. However, the former is a descriptive term, more technical, while the latter is more a disparaging term, containing strong negative connotations and associations in Chinese culture. ‘阴阳人' [an epicene person] is usually regarded as '怪物' [monster] and suffers strong social bias (Tang Zhen 2009, Ai Mi 2012, Yan Chenguo 2012). The term is also used to refer to a 'double-dealer' (Zhang Hao 2008). Such a term also reveals Tao's attitude towards lesbianism. 
11 ST: The truth is that homosexuality is no more a perversion deliberately indulged in than it is a curse of fate. (446)

$\mathrm{S} / \mathrm{N}$ : 事实是, 同性恋爱既非天生之命运, 亦非存心耽溺的变态。 (196)

[The fact is that homosexuality is not an innate fate, nor a deliberate perversion.]

Tao: 实际上, 同性恋既不是一种厄运, 也不是被有意纵情享受的一种 变态, $[\ldots]$. . (483)

[In fact, homosexuality is not a misfortune, nor a perversion deliberately indulged in, [...].]

Li: 事实上, 同性恋并非是一种厄运, 更不是故意恣情狂欢的变态, $[\ldots] \circ(177)$

[In fact, homosexuality is not a misfortune, nor a perversion deliberately indulged in, [...].]

The word 'curse' refers to something that causes harm or evil; 'fate' refers to either 'bad things that will happen or have happened to sb/sth' or 'the power that is believed to control everything that happened and that cannot be stopped or changed' (Hornby 2009: 491/733). If homosexuality is fate, society (in Beauvoir's time, and even today in some places) commonly regards such a fate to be very bad fortune. In TSS, Beauvoir challenges the society of her time, which regards homosexuality as something shameful and disgraceful. She wants to replace this very negative attitude with a positive one, and points out that homosexuality is 'no more a perversion deliberately indulged in than it is a curse of fate'. In other words, it is a way of life which is not perverse and therefore shameful, something which has nothing to do with fate. It is an attitude that is both motivated and freely adopted. S/N translate 'a curse of fate' into '天生之 命运' [an innate fate], which expresses the essence of the source text meaning, but the force behind 'a curse of fate' is lost. This to some extent reveals an attempt to remove social bias against homosexuality which Beauvoir intends to dismiss. Tao and $\mathrm{Li}$ both translate it as '厄运', meaning 'adverse/evil fate, misfortune' (Hui Yu 2011: 419), retaining the spirit of the source text.

\subsection{Lesbianism in the Chinese translations of The Vagina Monologues}

Female same-sex love in TVM is one of the ways for women to appreciate their bodies and enjoy sexual pleasure, 'represent[ing] a women-centered pleasure' (Cooper 2007: 750). The subject of lesbianism appears in two monologues: 'The Little Coochi Snorcher that Could [Southern woman of color]' (Ensler 2001: 77-82), and 'The Woman Who Loved to Make Vaginas Happy' (Ensler 2001: 105-111). The former recounts the vagina stories of a coloured southern woman at ages five, seven, nine, ten, thirteen and sixteen respectively. Half of 
the monologue is about her lesbian encounter at sixteen (thirteen in the 1998 version). The latter tells the story of a tax lawyer who enjoys making women happy and becomes a lesbian prostitute. She talks in great detail about her moaning, and at the end, she summarises as many as twenty types of moans. After the monologue, there is a section 'As a lesbian ...' (Ensler 2001: 115-118), a follow-up interview with the woman who loves to make vaginas happy. In this section, the woman gives an erotic description of how she has sex with women. This is actually an extended part of the monologue and therefore is discussed as part of the monologue. In addition, there is a monologue called 'The Vagina Workshop [A slight English accent]' (Ensler 2001: 43-50), which talks about a workshop teaching women masturbation. Since it is about women seeking sexual orgasm by themselves, this story is included as a variation of female samesex sexuality for the analysis here. These monologues challenge 'normal' heterosexuality, show an appreciation for lesbian love, and encourage women's autonomy in sexuality. They have all caused more or less controversy in their source context, and are an interesting test case for what may happen to them in the Chinese context. In what follows, the monologues are discussed according to the sequence in which they appear in TVM.

\subsection{1 'The vagina workshop'}

This monologue describes the experience of a woman who attends a vagina workshop to learn how to find and touch her clitoris to generate orgasms. It echoes 'The Flood' (Ensler 2001: 25-30) in resisting shame and explores a woman's connection to her vagina as a source of both pleasure and empowerment (Hammers 2006: 232). This workshop monologue is based on Dodson's 'Bodysex Workshop' which teaches women how to masturbate and how to find their clitoris, and helps women learn about orgasm by explaining the difference between clitoris and vagina (Bell and Reverby 2005: 434). Yet, Dodson thinks TVM talks about her Bodysex Workshop 'in a distorted view' of what she has been doing for over 25 years. Dodson vehemently rejects the word 'vagina', saying that " $[\mathrm{n}]$ ever in my wildest nightmare would I have ever considered using the word "vagina" (Dodson 2001); while for Ensler, vagina is the only word that is not derogatory (Braun and Ensler 1999: 518). This again exhibits the discrepancy, disunity, or multiplicity of feminism.

The translations by Chen Cangduo and Yu Rongjun are on the whole closer to the source text, representing what is given in the source text, except that $\mathrm{Yu}$ Rongjun removes the parenthetical note 'A slight English accent' from the title, severing the translated monologue from the English woman. Ai's translation is a rewriting in a colloquial and humorous way with detailed in-text parenthetical notes (see Examples 5 and 13 in Chapter Five). The notes have two functions: (1) to elaborate in detail the psychology of the woman who learned to respect her own body and regain her own body and sexuality in the workshop; and (2) to explain to the performers how to represent the woman's distance to and separation from her vagina and her 'desperate groping and her inability to find 
her clitoris without the aid of the workshop leader' (Hammers 2006: 233). Ai Xiaoming also removes the note to the title 'A slight English accent', but gives a subtitle ‘献给贝蒂・道森' [For Betty Dodson], which clearly locates the monologue in Betty Dodson's workshop, and brings the audience's attention to such a workshop in real life. Ai's translation shows and encourages '(re)imagining female subject positions in ways that embrace-rather than eschew-the importance of the body, particularly the vagina', and reveals that ' $[\mathrm{t}]$ hese subject positions are bold, creative, honest, and even a little defiant; they are also sexy and sexual' (Hammers 2006: 234).

The differences between the female and male translators in understanding and translating female sexuality discovered in Chapter Five also exist in their translations of this monologue, expressed in their lexical choices. The following are some examples.

12 ST: The woman who ran the workshop asked us to take out our hand mirrors again and to see if we could locate our clitoris. $(47-48)$

Chen: 工作坊的女主持者要我们再把手镜拿出来, 看看能否找出阴 核。(66)

[The female host of the workshop asked us to take out our hand mirrors again to see if we can find out our clitoris.]

$\mathrm{Yu}$ : 随后, 那个做工作坊的女人让我们再次拿出小镜子, 看看我们能 否找出我们自己的阴核。

[Then, the woman who ran the workshop asked us to take out the small mirrors again to see if we can find out our own clitoris.]

Ai: 主持工作坊的女人要求我们, 再拿出镜子来, 看谁能找出自己 的*。..., 那个从来没有人告诉我们有什么用的* (请注意, 这 里, 台词的意思是讽刺传统, 讽刺传统对待女人性器官的态度, 在性压抑文化中，女人的性是被控制的，怎么会告诉女人如何获 得快感呢)。

[The woman who ran the workshop asked us, to take out our mirrors again, to see who can find out their ${ }_{-}^{*} . .$. , that ${ }^{*}$ for which nobody had ever told us the use (Please note, here, the line is intended to satirise tradition, satirise the attitude of tradition to woman's sexual organ. In a culture of sexual repression, women's sexuality has been controlled, how can [such culture] tell women how to gain [sexual] pleasure).]

In this monologue, 'clitoris' is the key word. Chen Cangduo translates 'clitoris' into ‘阴核' [clitoris] throughout the monologue. Yu Rongjun translates it into ‘阴核' [clitoris] in this sentence only and into ‘阴蒂' [clitoris] throughout the rest of the monologue. ‘阴核' [clitoris] and ‘阴蒂' [clitoris] are two technical Chinese terms for clitoris. Their faithful translations can be regarded as achieving 
Ensler's purpose to demystify the female body and female sexuality, because an effective technique for demystifying something is to call a spade a spade. Repression of female sexuality in all its forms means that women are kept, by and large, ignorant of their own anatomy and physiology, as well as the related matter of their own sexuality. Such ignorance would naturally bring about ignorance of the names for female genitalia. Liberation from such ignorance and repression would, therefore, include teaching women not simply where that organ is to be found but also giving it its proper name- that is, to be proud of it by proclaiming to the world that it is called 'clitoris'. Hence Ensler rejoices in invoking it at every possible turn. The translations by Chen Cangduo and Yu Rongjun could be said to have retained this specific feminist charge.

Ai Xiaoming translates it in a dramatically different way. She adopts semiotic translation, turning 'clitoris' into a symbol '*' and adds a sentence '那个从来没 有人告诉我们有什么用的*' [that * for which nobody had ever told us the use] after the first appearance of the symbol, stressing that women have been kept ignorant of their own bodies, not to mention enjoying sexual pleasure. It is followed by a parenthetical note to tell performers (and readers) that this line is intended to satirise tradition and to expose the fact that women have been kept ignorant of their sexual organ; and in a culture of sexual repression, where women's sexuality has been controlled, how can such a culture tell women how to gain sexual pleasure? Ai's semiotic translation of 'clitoris' foregrounds the absence of female sexual pleasure. The added sentence and the note help readers and performers of the production understand the text, and make them aware of the sexual repression women have suffered.

13 ST: (I came into my own muscles and blood and cells and then I just slid into my vagina.) It was suddenly easy and I fit. (50).

Chen：情况忽然变得很容易, 很吻合。(68)

[It suddenly became very easy, very fit.]

Yu: 那里突然变得很容易而且合适。

[There it suddenly became very easy and suitable.]

Ai: 忽然, 一切变得很简单; 接着, 我的手指突然碰到了与我很和谐 的那个地方。

[Suddenly, everything became very plain; subsequently, my finger suddenly touched the place that is harmonious with me.]

The two short clauses 'It was suddenly easy' and 'I fit' at first sight do not appear to be intelligible, which must have caused trouble for the translators, as reflected in the Chinese translations. In the source text, 'easy' does not mean 'not difficult, done or obtained without a lot of effort or problems', but means 'comfortable, relaxed and not worried' (Hornby 2009: 632). When the woman in the workshop tried hard to search for her clitoris, she felt 'the panic coming', worrying that she 'did not have a clitoris' (Ensler 2001:48). Therefore, 'It was 
suddenly easy' expresses what the woman felt, physically and psychologically, when her hands reached her clitoris.

The verb 'fit' here also does not carry the usual meaning (such as 'to match or be suitable for sth') (Hornby 2009: 764). According to the World English Dictionary, when used informally and as an intransitive verb, 'fit' can mean 'to have a sudden attack or convulsion, such as an epileptic seizure' (Dictionary.com 2011). Obviously, 'fit' is not used in the literal sense here, but to describe the quivering of the woman's clitoris, a response to her hand touch and an expression of orgasm. This is made explicit in the following sentences: 'I was all warm and pulsing and ready and young and alive. [. . . There was a quivering at first, [...] Then the quivering became a quake, an eruption, [...]' (Ensler 2001: 50).

Chen Cangduo and Yu Rongjun both translate 'easy' into ‘很容易' [very easy], expressing one of the dictionary meanings of 'easy'. ‘容易' [easy] has two meanings in Chinese: 'not difficult' and 'likely', and does not contain the contextual meaning 'comfortable, relaxed and not worried' of the source text. They translate 'fit' into ‘很吻合' [very fit] and '合适' [very suitable] respectively, expressing the usual meaning or one of the dictionary meanings of 'fit' but not the meaning of the source text. In addition, they both turn the two short sentences into one, in an identical manner. Their literal translations make little sense in Chinese, while failing to convey the source text meaning. It might be difficult for the male translators to understand the mechanics of female masturbation. Lived experience, or gender, seems to have played a role here.

Ai Xiaoming translates 'easy' into '很简单' [very plain], expressing the sense of the source text. When something becomes 'plain', it is 'easy' and there is no need to worry. She translates 'I fit' into '我的手指突然碰到了与我很和谐的那 个地方' [my finger suddenly touched the place that is harmonious with me], which implies the source text meaning. '和谐' literally means 'harmonious, melodious' (Hui Yu 2011). It can be used in a sexual context. For example, the idiom ‘琴瑟和谐' [marital harmony] refers to a harmonious relationship between husband and wife, and can also be used to refer to harmonious sexual love. Therefore, '和谐' [harmonious] can be seen as a roundabout expression of the orgasm the woman achieved. Overall, Ai's translation of the two sentences makes sense and conveys the source text meaning, although the language she uses is very implicit. Her lived experience may have helped her in translating female masturbation. Ai's translation also shows that like $S / N$ and $W / Q, A i$ Xiaoming as a woman seems conservative in expressing female sexuality.

14 ST: and I felt connection, calling connection as I lay there thrashing about on my little blue mat. (50).

Chen: 我感觉到连接的关系, 喊叫着连接的关系, 同时我躺在那儿, 在 我那块小小的蓝色席垫上疯狂地打转。(66)

[I felt the relationship of connection, cried the relationship of connection, at the same time I lay there, on my little blue mat crazily turning round and round.] 
Yu: 所有这些都和我紧紧相连在一起, 而我只是躺在那些蓝色的鲜亮 的席子之上。

[All these were closely connected with me, while I only lay on these blue and bright mats.]

$\mathrm{Ai}$ : 我感觉到了, 我喊叫着, 我在我的蓝色的垫子上重新获得了它。 [I felt it, I cried, I on my blue mat again achieved it.]

The beginning of the monologue tells that the woman who attended the workshop had had accidental orgasms but did not know how to make one happen and never tried to make one happen. This selected passage describes that the woman burst into a happy cry when she achieved orgasm by masturbation. That is to say, she learned how to make one happen. The source text 'I felt connection, calling connection' does not appear to make much sense at first sight to non-English speakers like the Chinese, which must have also caused problems for the translators, as reflected in their translations. According to the World English Dictionary, 'connection' has a rare usage, meaning 'sexual intercourse' (Dictionary.com 2011). Such usage can hardly be found in general dictionaries. Here 'connection' refers to the woman's success in finding her 'locus' and reaching orgasm through masturbation. When she felt it, she cried with ecstasy. '[T]hrashing about' (meaning 'move in a violent or uncontrolled way') shows the woman's ecstasy at that moment (Hornby 2009: 2105).

Chen's translation of 'felt connection, calling connection' into '感觉到连接 的关系, 喊叫着连接的关系' [felt the relationship of connection, cried the relationship of connection] and Yu's translation '和我紧紧相连在一起' [closely connected with me] are based on the literal or surface meaning of 'connection', which make little sense in the Chinese sentence and fail to convey the source text meaning. Chen's '疯狂地打转' [crazily turning round and round] is a literal translation of 'thrashing about', which fails to represent the bodily movements of the woman while creating a funny picture. The phrase 'thrashing about' disappears in Yu's translation and the woman's excitement is also lost. Ai Xiaoming also omits 'thrashing about', but the woman's excitement is expressed in 'I cried'. The translation by Ai Xiaoming is very brief but clearly expresses the gist of the source text. This example again shows that the male translators could be disadvantaged in understanding and translating female sexuality.

\subsection{2 'The Little Coochi Snorcher That Could'}

This monologue seems to be the most controversial among the three and has attracted much backlash. It involves a woman recounting memories of her sexual experience, erotic or violent, 'a private history of self-loathing turned to self-love' in her childhood (Cooper 2007: 743). 'Coochi snorcher' is a slang term for vagina, used as the nickname of the 13-year-old girl's genitalia (she is sixteen in the 2001 revised version). What makes the monologue controversial is the section about her first sexual encounter with a 24 -year-old woman, and 
the way she learned to appreciate her 'coochi snorcher', a part of her body that had, in the past, brought her only pain. In the story, the woman kissed her in the car and invited her to stay over at her house. The woman gave her vodka before seducing her. Up to then, the girl had always thought of her coochi snorcher as nasty. But the older, experienced woman taught her how to give herself pleasure so that she would never need to rely on a man. As a result, the young girl came to regard the seduction as her 'surprising, unexpected, politically incorrect salvation' and said that this woman took her vagina and 'raised it up into a kind of heaven' (Ensler 2001: 82).

In America, it is illegal to ply a child with vodka, especially with the intention of sexually violating or seducing the child in question. Therefore, many people take what happened to the girl to be statutory rape even if the girl consented. Both by statute and by feminist definition, the 'seduction' scene is rape, although the girl declared that 'if it was rape, it was a good rape' (Ensler 1998: 75). It is generally thought that regardless of the gender, sex should not be experienced between adults and children because adults ultimately hold the power in these situations, and that rape is wrong, no matter the sex or the sexual orientation of the person who commits it or whether it is statutory or not. Thus this story has come to be justified paradoxically as an example of sexual violence that is not 'violent' (Swope 2000, McElroy 2000 and 2002, Cleaveland 2006, Samhita 2006, BCatholic 2008).

Consequently, the original performances of the play and the published text have been attacked as promoting lesbianism, paedophilia and the view that men are violent and women are victims, and idealising child molestation by eulogising the lesbian 'rape' of a 13-year-old girl by a 24-year-old woman who plies her with alcohol (McElroy 2002 and 2004). Thus, the sentence in which the girl calls her rape 'good' is eliminated from the performances of 1999 and from the revised 2001 text, and the girl becomes sixteen in the revised 2001 text (Swope 2000, McElroy 2000, 2002 and 2004, Renshaw 2004: 324, Ensler 2001: 80). The play is no longer to be performed from the original text but from a special script that is distributed for use to campus groups that meet the organiser's requirements. Unlike V-Days 1999 and 2000, the organisers of 2001 laid down rules. The 2001 feminist.com site, which coordinated performances, requires that performances for anti-violence or campus events adhere to the new script:

You must use the version [...] that is included in the Performance Kit that you will receive. No other version of the play is acceptable for your production. Do not use the book of the play or versions of the script from previous College Initiatives.

(McElroy 2000 and 2002)

In the three translations of this monologue, Chen Cangduo and Ai Xiaoming keep close to the first published version in 1998, and in their translations, the girl remains 13 years old and the 'good rape' is there. Yu Rongjun changes the 
girl's age from thirteen to sixteen and eliminates the 'good rape', making his translation conform to the new rules. This change may also be out of the consideration that thirteen is too young and less acceptable to the audience or social norms. ${ }^{1}$ Chen Cangduo published his translation in 2000; thus the new rules do not apply to his translation as they came out later. Ai Xiaoming was invited to join the V-Day productions in 2003 after the new rules came out. However, it seems that her translation was not affected by the new rules. She did not make any changes in her translation of this monologue to accommodate the new rules, although her translation of the play shows that she knew about the new changes because she did take some new skits from the revised version or new script, such as 'Because He Liked to Look at It', which appears in the revised 2001 edition, and 'My Short Skirt', one of the two new skits added in the show of 2000 by Ensler (Tucker 2002). Yu Rongjun updated his translation here as well as in other sections.

The following is the end of the monologue, showing the difference between the 1998 version and the revised 2001 version, and between the three translations.

15 ST: (Now people say that it was a kind of rape. I was only thirteen and she was twenty-four.) Well, I say, if it was a rape, it was a good rape then, a rape that turned my sorry-ass coochi snorcher into a kind of heaven. (1998: 75)

Chen: 嗯, 我说, 如果那是一种强暴, 那么那是一种不错的强暴! 这种 强暴把我那可怜的孔儿变成一种天堂。(85)

[Um, I say, if that is a kind of rape, then that is a pretty good rape; this kind of rape turned my poor hole into a kind of heaven.]

Ai: 恩, 我说, 如果那是强暴, 那可真是挺不错的经验; 这种经验, 把我可怜的阴道变成了天上的伊甸园。

[Um, I say, if that is a rape, that is a pretty good experience; this kind of experience, turned my poor vagina into a heavenly paradise.]

cf.: ST: I realized later she was my surprising, unexpected, politically incorrect salvation. She transformed my sorry-ass coochi snorcher and raised it up into a kind of heaven (2001: 82).

Yu: 我意识到她其实是我的拯救者, 一个惊喜, 一个意外, 一个及时 而正确的拯救者。是她彻底改变了我的库奇斯洛切, 是她把那儿 变了 $(\mathrm{sic})$ 一个极乐世界。

[I realised that she is actually my salvation, a surprise, an accident, a timely and correct salvation. It is she who thoroughly changed my coochi snorcher; it is she who turned it into an Elysium.]

The word 'rape' means 'the crime of forcing sb to have sex with one, especially using violence' (Hornby 2009: 1639). The source text attempts to convey the 
defiance in the feminist attitude and its determination to celebrate all manifestations of lesbian sexuality. 'A good rape' can therefore be interpreted to say: 'We lesbians want sex, even if it amounts to rape'. Chen Cangduo translates 'rape' into '强暴' [rape], the same as the source text. Ai Xaioming translates it into '经验' [experience]. As 'rape' has appeared in the if-clause, 'experience' in the main clause can be seen as another way to refer to rape to avoid repetition. Since 'it was a good rape', with no violence and no forcing, it may be more appropriate to call the rape an 'experience'. Chen's '一种不错的强暴' [a pretty good rape] and Ai's '挺不错的经验' [a pretty good experience] all convey the source text meaning. Yu's translation is based on the 2001 version, in which 'rape' is removed and 'politically incorrect' is used instead to make the text appear politically correct. It is interesting to see that $\mathrm{Yu}$ Rongjun translates 'politically incorrect' into '及时而正确的' [timely and correct], paying no attention to Ensler's compromise to make the text politically correct and to some extent retaining the spirit of bravado and defiance in the 1998 text. All the three translations more or less reflect a feminist stance.

16 ST: (A gorgeous 24-year-old woman in our neighborhood invites me, a 16-year-old girl, to her house and spends the night. My mother is delighted that such a beautiful, successful woman has taken an interest in me. Her apartment is fantastic. I decide right there that) I want to be a secretary like her when I grow up. $(80)$

Chen: 我长大时要像她那样成为一个女秘书。(83) [when I grow up, I will be a female secretary like her.]

Yu: 我长大了以后一定要向她那样——做个秘书。 [when I grow up, I will be like her-to be a secretary.]

$\mathrm{Ai}$ ：等我长大了, 也要做个成功女人, 就像她那样。 [when I grow up, I will also be a successful woman, just like her.]

In Example 16, the three translators treat 'secretary' differently. In the source text, 'secretary' is unmarked. Chen Cangduo turns it into marked form '女秘书' [female secretary], which often contains a complex and equivocal message and has a negative connotation in Chinese culture. A female secretary is often regarded as an equivalent to a lover because there are many examples of a female secretary ending up being the lover of her boss. Chen's translation seems to be paying no attention to the effect on the Chinese audience. Yu's translation '秘书' [secretary] is the same as the source text which looks rather neutral. Ai Xiaoming translates 'secretary' into '成功女人' [ successful woman], foregrounding what TVM has described about the woman: a gorgeous 24-year-old woman, and a beautiful and successful secretary. Ai Xiaoming seems to be trying to avoid the negative connotation around '(female) secretary'. Her translation conveys the 
positive attitude of the source text towards the lesbian woman, which is not seen in the men's translations.

17 ST: (In the morning, I am worried that I've become a butch because I'm so in love with her. (82).

Chen: 我担心自己变成了女同性恋中扮演男性的一方, 因为我是那么爱 着她。(85)

[I am worried that I have become a lesbian who plays the role of a man, because I love her so much.]

Yu: 我很担心我就此变成了一个婊子, 因为我很爱她。

[I am worried that I have thus become a whore, because I love her very much.]

Ai: 我担心自己已经变成了一个男人, 因为我是那么、那么地爱着 她。

[I am worried that I have become a $\underline{\operatorname{man}}$, because I am so greatly in love with her.]

The word 'butch' in the source text was an offensive term for a masculine lesbian at least till the end of the 1980s. In the Oxford Advanced Learner's Dictionary of Current English (Hornby 1984/1990: 155) and the Collins Cobuild English Language Dictionary (Sinclair 1987: 190), the term was marked as offensive. It seems the term has gradually lost its derogatory implication with increased social tolerance of lesbianism, especially the development of lesbian feminism. In later dictionaries, such as The Concise Oxford Dictionary of Current English (Allen 1990: 152), The New Shorter Oxford English Dictionary on Historical Principles (Brown 1993: 307), and the Collins English Dictionary (Wilkes et al. 1998: 218), the term is no long marked as 'offensive' or 'derogative'.

Chen's translation of 'butch' as ‘女同性恋中扮演男性的一方’ [a lesbian who plays the role of a man] explains the role of such a lesbian with no offensive implication. As a translator of erotic books (see 3.4), he seems to have a good understanding of different sexual orientations. Yu Rongjun translates it into '婊子' [whore], a very disparaging term for a prostitute in Chinese culture. '婊子' [whore] is usually considered as even more degraded than a prostitute, revealing either Yu's unconscious dislike for lesbianism, or an absolutely conscious dislike for lesbians and his desire to degrade them. Ai Xiaoming translates it into 'a man', which also explains the role of such a lesbian without any derogatory connotation. Moreover, her translation fits the tone and cognitive level of the young girl.

\subsection{3 'The Woman Who Loved to Make Vaginas Happy'}

This is another controversial monologue, which talks about a successful tax attorney who leaves her career to become a lesbian dominatrix prostitute and 
gives examples of various orgasmic moans. Dramatic differences can be seen between the three Chinese translations. As usual, Chen Cangduo adopts a literal translation to deal with the whole monologue and the follow-up interview with the lesbian, on whose interview Ensler has based the monologue. In Yu's translation, a couple of lines are removed here and there, and the follow-up interview is not included. In the follow-up interview, the interviewee gives a graphic description of lesbian sex, which seems more suitable for reading privately than presenting publicly on the stage. This could be the reason Yu Rongjun cuts it. Yu's translation looks literal here and there, but overall more poetic than Chen's translation. Like Yu Rongjun, Ai Xiaoming also cuts the unstageable follow-up interview 'As a lesbian ...', removing the 'embarrassing' lesbian sex (Ensler 1998: 100). And she makes dramatic changes to the monologue, leaving the specific story and adapting the moaning content into a Chinese sketch '呻吟' [Moaning], a Chinese story about moans. One year later in 2004, Ai Xiaoming was invited to watch the production by $\mathrm{Fu}$ Dan University, the first campus production in China and a production completely by students. In this production, the lesbian love was retained. She was amazed at the bold way the students challenged the cultural taboo and was happy to see promise in these young people (Bu Wei 2004).

In Ai's rewritten story, the series of moans in the source text are turned into Chinese types of moans. The 'full multicultural spectrum' of moans, 'from the Greek Slick moan to the WASP moan to that of a militant bisexual', may be interesting and amusing to Western audiences (Cooper 2007: 750), as I found from the 2008 production at the University of Manchester: the moans produced a humorous effect and won much laughter when they were performed on the stage. However, a literal or faithful translation of them (as Chen Cangduo and $\mathrm{Yu}$ Rongjun have done) looks rather alien to Chinese audiences and can hardly arouse their interest and imagination. This may be the reason for Ai Xiaoming localising or domesticating the monologue, which recreates the humour of the source text. The adapted moaning story becomes a comedy of three Chinese women: A (single?), B (has a boyfriend), and C (married). A asks B and C whether they have ever heard of moaning. C is shocked by A's boldness in talking about moaning, and tells a sad story in her village where there still exists a culture of “听房' [listening outside the bridal chamber]. In the story, a mischievous young man put a mini-recorder under the bed of the newlyweds, and played what he recorded to the villagers the next day. The bride happened to come out to wash clothes. Some young men imitated her moaning in her presence. Unable to bear such shame, the bride immediately ran home and hanged herself. B can hardly believe that a person would commit suicide for such a reason. She boasts that she enjoys moaning at birth and that she often moans: when she has bought tasty food in the canteen or new clothes, and especially when she reaches an orgasm in making love to her boyfriend. A and $\mathrm{B}$ both perform several types of moans, and encourage $\mathrm{C}$ to do it. $\mathrm{C}$ at first feels shy and ashamed of doing it, declaring that she and her husband have never moaned, but she finally joins them. They have much fun performing 
moans. This story exhibits that rural women, especially those in backward areas, suffer more sexual repression.

The language each character speaks has symbolic meaning and humorous effect. A speaks Cantonese, B Mandarin, and C Henan dialect. Mandarin represents modern and liberal culture; Cantonese, open and permissive culture; and Henan dialect, backward and conservative culture. Henan is a large agricultural province in Central Eastern China. It is generally regarded as an underdeveloped and backward place. Henan dialect immediately evokes an impressive picture of underdevelopment and backwardness. Therefore, in the production, A is a smartly dressed girl from Guangzhou, while $\mathrm{C}$ is a rural woman from a village in Henan. All the information about B in the script implies that she is an educated, modern girl: she speaks Mandarin which is spoken mostly by educated people, she often buys new clothes, and she moans at will when making love to her boyfriend. Different pronunciations, especially Henan dialect and Cantonese, make it amusing. Henan dialect and Cantonese (and North Eastern dialect as well) are the major dialects adopted in comic skits, such as those staged in CCTV's yearly Spring Festival Gala (held on the eve of the lunar New Year, an annual must-see event for many Chinese people). Such skits, usually humorous and/or satirical, are meant to make people laugh and think. Ai's localising serves this purpose. The Chinese sketch brings the moaning story very close to the Chinese audience and adds much humour to the production. While making the audience laugh, it reminds the audience of the big urban-rural gap, exposes patriarchal oppression, and encourages women to enjoy sexual pleasure.

The production also makes good use of intertexuality to the well-known Henan opera 花木兰 [Lady General Hua Mulan]. The opera is about a legendary Chinese heroin Hua Mulan, who disguised herself as a boy to take her sick father's place in the army. She gained high merit, but refused any reward and returned home to take care of her family. Hua Mulan is regarded as a model of filial piety, braveness and courage. In the play, a widely known line by Hua Mulan is: '谁说女子不如男' [who says a woman is inferior to a man]. Encouraged by $\mathrm{A}$ and $\mathrm{B}, \mathrm{C}$ imitates moans and belts out to the tune of the opera: '谁说女子不能叫' [who says a woman cannot moan]. This allusion evoked hearty laughter and cheering. It is praised to have produced the effect of subverting a taboo topic into a hilarious revel and rewriting power relations between women and men with laughter (Xiao Hui 2009: 64). The line challenges the traditional view of women's sexual behaviour and encourages women to enjoy sexual equality. Ai Xiaoming rewrites the story to challenge traditional sex culture that has suppressed female sexuality and ignored female sexual experiences (Ai Xiaoming in Zhang Qi and Pang Minghui 2003).

The vice-director of the production, Song Sufeng, explained that in order to achieve reception by the audience and avoid the embarrassment of the performers, three actresses were arranged to perform 'Moaning', with local dialects and Henan opera used in jest. She pungently points out that when performers do not need to make gags in their performance, and can perform 'Moaning' in a direct way and melt themselves in the scene, it would mean that female 
sexuality is liberated to a certain degree in China (Anonymous 2005). In view of the fact that prostitution is illegal and homosexuality is largely unacceptable in China, it is understandable that Yu cuts the graphic description of lesbian sex, and Ai Xiaoming rewrites the whole story based on the moaning motif of the monologue and even turns the homosexual moans into heterosexual moans. Since the two Mainland translations are not published in book form and circulated only on the internet, such omission and rewriting can be understood as an act of self-censorship by the translators themselves for better reception. Chen's translation shows no omission, which reflects a more permissive social environment for lesbianism in Taiwan. The issue of censorship will be discussed in detail in Chapter Seven.

\subsection{Summary}

In the fourteen cases of translation differences in Examples 1 to 11 from TSS, six translation strategies are identified: repetition, attenuation, literal translation, amplification, bilingual translation, and transliteration. The number of times the translators use the strategies is summarised in Table 6.1. S/N use only two strategies: repetition in eleven of the fourteen cases, and attenuation in three cases, keeping close to the source text. Tao uses as many as six strategies and $\mathrm{Li}$ four. He uses literal translation in five cases, amplification in three cases, and attenuation in two cases, which disclose either his negative attitude towards lesbianism or his difficulty in understanding lesbian sexuality. He uses bilingual translation in Examples 4 to 5 in the same way as Chen Cangduo does in translating the female body in TVM (see Examples 1 and 3 in Chapter Five). In the seven cases, Li uses literal translation three times, attenuation twice, and amplification once, which disclose either his negative attitude towards lesbianism or his difficulty in understanding lesbian sexuality. Repetition appears only once in Tao's and Li's translation. In the examples of translating lesbianism in TSS, 'man translation' appears again. Tao and Li use the same or similar words or expressions in four of the five examples where Li's translation is present (see Examples 2, 6, 8 and 11). A feminist stance or sympathy with lesbianism

Table 6.1 Number of times the strategies are used (TSS, Examples 1-11, 14 cases)

\begin{tabular}{lccl}
\hline Strategies & $S / N$ (No. of times) & Tao (No. of times) & Li (No. of times) \\
\hline Repetition & 11 & 1 & 1 \\
Attenuation & 3 & 2 & 2 \\
Amplification & - & 3 & 1 \\
Literal translation & - & 5 & 3 \\
Bilingual translation & - & 2 & - \\
Transliteration & - & 1 & 0 \\
Total & 14 & 14 & 7 \\
\hline
\end{tabular}

NB: Examples 1, 3 to 5, and 9 to 10 are cut in Li's translation, and only seven cases in five examples are involved here. 
Table 6.2 Number of times the strategies are used (TVM, Examples 12-18, 9 cases)

\begin{tabular}{llcc}
\hline Strategies & Chen (No. of times) & $\Upsilon_{u}$ (No. of times) & Ai (No. of times) \\
\hline Repetition & 4 & 2 & 5 \\
Literal translation & 4 & 4 & - \\
Amplification & 1 & 2 & 1 \\
Omission & - & 2 & 2 \\
Localising & - & - & 1 \\
Semiotic translation & - & - & 1 \\
Total & 9 & 10 & 10 \\
\hline
\end{tabular}

is seen in S/N's translation (such as Examples 4, 5, 6(2), and 11). In several cases, the men's translations make little sense or fail to express the source text meaning (such as Examples 3, 6(1), and 7). Sometimes, the men's translations contain negative connotations (such as Examples 6(2), 9, and 10). Mistranslation and misunderstanding appear in a few cases in the men's translations (such as Examples 1(2), 2 and 8).

In the nine cases of translation differences in Examples 12 to 18 from TVM, six translation strategies are identified: repetition, literal translation, amplification, omission, localising, and semiotic translation. The number of times the translators use the strategies is summarised in Table 6.2. Chen mainly uses repetition (five times) and literal translation (four times), with amplification used once. Yu also mainly uses literal translation (four times), with repetition, amplification and omission each used twice. Ai mainly uses repetition (five times), with omission used twice and amplification, localising and semiotic translation used once. A feminist stance is seen in Ai's translation (such as Examples 12, 15, 16 and 18), and also in the translations by the male translators Chen and Yu (such as Examples 12 and 15). In a few cases, the men's translations make little sense or fail to express the source text meaning (such as Examples 13 and 14). Sometimes, the men's translations contain negative connotations (such as Examples 12, and 16) or show dislike for lesbianism (such as Example 17). In general, the analyses in 6.1 and 6.2 produce similar results to each other and to the results in Chapters Four and Five.

\section{Note}

1 A similar case is that of Queer As Folk. In the original British version, one of the main characters is a 15-year-old boy who loses his virginity. In the American version, the age is changed to seventeen (almost eighteen).

\section{Bibliography}

Ai, Mi 艾米 (2012) ‘阴阳人’ [A Bisexual Person], http://blog.sina.com.cn/s/blog_ $4 \mathrm{e} 5 \mathrm{~d} 62450102 \mathrm{e} 2 \mathrm{wu} . \mathrm{html}$ (last accessed on 28 June 2013).

Ai, Xiaoming 艾小明 (trans.) (2003) 阴道独白 [The Vagina Monologues], http://smileinwind. bokee.com/2440712.html (last accessed on 31 March 2006). 
— (2004) ‘全球女性主义口述史访谈’ [An Interview on Global Feminist Oral History], www.umich.edu/ glblfem/en/transcripts/china/aixiaomingm.pdf (last accessed on 22 February 2008).

Allen, R. E. (ed.) (1990) The Concise Oxford Dictionary of Current English (8th edition), first edited by H. W. Fowler and F. G. Fowler, Oxford: Clarendon Press.

Altman, Meryl (2007) 'Simone de Beauvoir and Lesbian Lived Experience', Feminist Studies 33(1): 207-232.

Anonymous (2005) ‘戏剧一阴道独白’ [Drama一The Vagina Monologues], http://myweb. ncku.edu.tw/ kailing/generaled/g\&l_s05/activity.htm, (last accessed on 4 July 2008).

— (2010) ‘范冰冰与女导演舌吻, 太那个了 ... 真受不了 ... [ [Fan Bingbing Tonguekissed the Female Director, Really Too Much . . . Really Unbearable ... .], http://bbs.ent.163. com/bbs/bagua/191015368.html? fromBbsFloat (last accessed on 5 November 2010).

BCatholic (2008) 'The Little Coochi Snorcher that Could', http://bcatholic2.blogspot. com/2008/01/little-coochi-snorcher-that-could.html (last accessed on 10 August 2008).

Beauvoir, Simone de (1975) Force of Circumstance, translated by Richard Howard, Harmondsworth: Penguin. The French original was first published in Paris by Librairie Gallimard in 1963.

_ (1993) The Second Sex, translated and edited by H. M. Parshley, New York: Knopf. Bell, Susan E. and Susan M. Reverby (2005) 'Vagina Politics: Tensions and Possibilities in The Vagina Monologues', Women's Studies International Forum 28: 430-444.

Braun, Virginia and Eve Ensler (1999) 'Virginia Braun in Conversation with Eve Ensler: Public Talk about "Private Parts"', Feminism \& Psychology 9(4): 515-522.

Brown, Lesley (ed.) (1993) The New Shorter Oxford English Dictionary on Historical Principles, Oxford: Clarendon Press.

Bu, Wei (2004) '从上海到全国' [From Shanghai to the Whole China], http://cyc6. cycnet.com:8090/othermis/stopdv/content.jsp?id=9024\&scode=0201020101 (last accessed on 6 July 2008).

Chen, Cangduo 陈苍多 (trans.) (2000) 阴道独语 [The Vagina Monologues], Taibei: 新雨出版社 [Xinyu Publishing House].

Cleaveland, Adam Walker (2006) 'The Vagina Monologues', http://pomomusings.com/ 2006/02/19/the-vagina-monologues/(last accessed on 11 August 2008).

Cooper, Christine M. (2007) 'Worrying about Vaginas: Feminism and Eve Ensler's The Vagina Monologues', Signs 32(3): 727-758.

Dictionary.com (2011) 'connection', http://dictionary.reference.com/browse/connection (last accessed on 20 October 2011).

- (2011) 'fit', http://dictionary.reference.com/browse/fit (last accessed on 20 October 2011).

Dodson, Betty (2001) 'Vagina Monologues \& V-Day', www.bettydodson.com/vaginano. htm (last accessed on 12 August 2008).

Ensler, Eve (1998) The Vagina Monologues, New York: Villard.

— (2001) The Vagina Monologues: The V-Day Edition, New York: Villard.

Fuchs, Jo-Ann P. (1980) 'Female Eroticism in "The Second Sex"', Feminist Studies 6(2): 304-313.

Gao, Juefu 高觉敷 (trans.) (1984/2004) 精神分析引论 [Introductory Lectures on Psychoanalysis], Beijing: 商务印书馆 [The Commercial Press].

Ge, Chuangui 葛传椝, Lu Gusun 陆谷孙, and Xue Shiqi 薛诗绮 (chief eds) (2000/2002) 新英汉词典（世纪版） [A New English-Chinese Dictionary (Century edition)], Shanghai: 上海译文出版社 [Shanghai Translation Publishing House]. 
Hammers, Michele L. (2006) 'Talking About "Down There”: The Politics of Publicizing the Female Body through The Vagina Monologues', Women's Studies in Communication 29(2): 220-243.

Ho, Loretta Wing Wah (2008) 'Speaking of Same-sex Subjects in China', Asian Studies Review 32(4): 491-509.

Hornby, A. S. (ed.) (1984/1990) Oxford Advanced Learner's Dictionary of Current English (4th edition, 2nd impression), A. P. Cowie (Chief ed.), Oxford: Oxford University Press.

— (ed.) (2009) 牛津高级英汉双词典（第7版） [Oxford Advanced Learner's EnglishChinese Dictionary] (7th edition), translated by Wang Yuzhang 王玉章, Zhao Cuilian 赵翠莲, Zou Xiaoling 邹晓玲, Beijing: 商务印书馆 [The Commercial Press], Oxford University Press.

Hui, Yu 惠宇 (ed.) (2011) 新世纪汉英大词典 [A New Century Chinese English Dictionary], Beijing: 外语教学与研究出版社 [Foreign Language Teaching and Research Press].

Li, Qiang 李强 (trans.) (2004) 第二性 [The Second Sex], Beijing: 西苑出版社 [Xiyuan Publishing House].

$\mathrm{Li}$, Yinhe 李银河 and Wang Xiaobo 王小波 (1992) 他们的世界一一国男同性恋群落 透视 [Their World-An Investigation into the Chinese Gay Community], Hong Kong: 香港天地图书公司 [Hong Kong Cosmos Books Ltd].

Liu, Dalin 刘达临 and Lu Longguang 鲁龙光 (2004) 中国同性恋研究 [A Study on Homosexuality in China], Beijing: 中国社会出版社 [China Social Press].

Lu, Gusun 陆谷孙 (chief ed.) (1989/2003) 英汉大辞典（上卷） [The English-Chinese Dictionary (unabridged) (Volume 1)], Shanghai: 上海译文出版社 [Shanghai Translation Publishing House].

Ma, Shanji 马善记 (2010) ‘范冰冰舌吻女导演让人恶心’ [It is Disgusting that Fan Bingbing Tonguekissed the Female Director], http://blog.ifeng.com/article/8476624.html (last accessed on 5 November 2010).

McElroy, Wendy (2000) 'The “Monologues” Ride Again', www.lewrockwell.com/mcelroy/ mcelroy 19.html (last accessed on 10 August 2008).

_ (2002) 'Take Back Valentine's Day!' www.ifeminists.com/introduction/editorials/ 2002/0212.html (last accessed on 10 August 2008).

_ (2004) 'A Not Very Funny Valentine', www.canadiancrc.com/NewspaperArticles/ FoxNotFunnyValentine27JAN04.asp (last accessed on 11 August 2008).

Renshaw, Sal (2004) 'Divine Gifts and Embodied Subjectivities in The Vagina Monologues', International Feminist Journal of Politics 6(2): 318-325.

Samhita (2006) 'Vagina Monologue Backlash', www.feministing.com/archives/002752. html (last accessed on 10 August 2008).

Sang, Zhuying 桑竹影 and Nan Shan 南珊 (trans.) (1986) 第二性一女人 [ The Second Sex一Women], Changsha: 湖南文艺出版社 [Hunan Literature \& Art Publishing House].

Simons, Margaret A. (1999) Beauvoir and The Second Sex: Feminism, Race, and the Origins of Extentialism, Lanham, MD: Rowman \& Littlefield Publishers.

Simons, Margaret A. and Jessica Benjamin (1979/1999) 'Beauvoir Interview', in Margaret A. Simons, Beauvoir and The Second Sex: Feminism, Race, and the Origins of Extentialism, Lanham, MD: Rowman \& Littlefield Publishers, 1-21.

Sinclair, John (chief ed.) (1987) Collins Cobuild English Language Dictionary, London and Glasgow: Collins Publishers.

Swope, Robert (2000) 'Applauding Rape at Georgetown', www.academia.org/campusreports/2000/may20004.html (last accessed on 10 August 2008). 
Tang, Zhen 唐珍 (2009) ‘不想再做“阴阳人”, [Don’t Want to Be ‘an Epicene Person’ Any More], 《生命时报》[Life Times], 16 October 2009, page 14, http://paper.people. com.cn/smsb/html/2009-10/16/content_363043.htm (last accessed on 26 July 2010).

Tao, Tiezhu 陶铁柱 (trans.) (1998) 第二性（全译本）[The Second Sex (complete translation)], Beijing: 中国书籍出版社 [China Books Publishing House].

Thompson, Della (chief ed.) and Chen Kai 陈凯 (trans.) (2003) 牛津现代英汉双解 词典（新版） [Concise Oxford English-Chinese Dictionary (new edition)], Beijing: 外语 教学与研究出版社 [Foreign Language Teaching and Research Press], Oxford University Press.

Tucker, Charlotte (2002) 'V-Day Filled with Moans, Screams: Vagina Monologues Draws Hundreds to David Lawrence', http://media.www.pittnews.com/media/storage/ paper879/news/2002/02/15/News/VDay-Filled.With.Moans.Screams-1795031.shtml (last accessed on 11 August 2008).

Wen, Jianguo 文建国 and Luo Lina 罗丽娜 (executive eds.) (2009) '2009年中国同性恋 生存状况调查报告' [2009 Research Report on the Living Conditions of Homosexual in China], 39 健康网 www.39.net, 广州启生性息技术有限公司 [Guangzhou LifeEnlightening Sex Information and Technology Ltd].

Wilkes, G. A., W. A. Krebs and W. S. Ramson (1998) Collins English Dictionary (4th edition), Glasgow: HarperCollins Publishers.

Wittig, Monique (1997) 'One Is Not Born a Woman?', in Katie Conboy, Nadia Medina and Sarah Stanbury (eds) Writing on the Body: Female Embodiment and Feminist Theory, New York: Columbia University Press, 309-317.

Wu, Guanghua (chief ed.) (1993/2002) 汉英大辞典（第二版） [Chinese-English Dictionary (2nd edition)], Shanghai: 上海交通大学出版社 [Shanghai Jiao Tong University Press].

- (chief ed.) (1998) 英汉科技大辞典 [An English-Chinese Dictionary of Science and Technology], Shanghai: 上海交通大学出版社 [Shanghai Jiao Tong University Press].

Xiao, Hui 肖慧 (2009) ‘《阴道独白》的跨国旅行' [Transnational Voyage of The Vagina Monologues], 妇女研究论丛 [Collection of Women's Studies] 2, http://qkzz.net/ article/8ad0ae2e-736c-45a9-b5al-d007c6602c4e.htm (last accessed on 7 June 2009).

Xin Feng 信风 (2010a) ‘费翔爱上刘文正有何不可' [Why Shoudn't Fei Xiang Fall in Love with Liu Wenzhang], http://xf1798.blog.sohu.com/162004933.html (last accessed on 5 November 2010).

— (2010b) ‘舌吻女导演, 范冰冰还有什么不敢做?’ [Tonguekissing the Female Director, What Else Does Fan Bingbing not Dare to Do?], http://xfl798.blog.sohu.com/ 162133141.html (last accessed on 5 November 2010).

Yan, Chenguo 间辰国 (2012) ‘阴阳人’ [Epicene People], http://blog.tianya.cn/blogger/ post_read.asp? $\mathrm{B} \log I \mathrm{D}=2892331$ \&PostID=44919524 (last accessed on 28 June 2013).

Yu, Rongjun 喻荣军 (trans.) (2003) 阴道独白 [The Vagina Monologues], http://bbs. sachina.pku.edu.cn/archiver/tid-3681.html (last accessed on 27 December 2006).

Zhang, Hao 张浩 (2008) '阴阳人’ [Double-dealers], http://blog.sina.com.cn/s/blog_ 4a21a96f01009hou.html (last accessed on 26 July 2010).

Zhang, Qi 张祺 and Pang Minghui 庞明慧 (2003) ‘重新想象女性的身体: 《阴道独白》 广州演出综述' [Re-imaging the Female Body: A Review of the Performance of The Vagina Monologues in Guangzhou], http://cyc6.cycnet.com:8090/othermis/stopdv/ content.jsp?id=8812 (last accessed on 6 July 2008).

Zhou, Quan 周泉, Yan Zesheng 严泽胜, and Zhao Qianghai 赵强海 (trans.) (2000/2007) 精神分析导论讲演 [Introductory Lectures on Psychoanalysis], Beijing: 国际文化出版公司 [International Cultural Publishing Corporation]. 


\section{Censorship, sexuality, and translation}

Censorship in translation is considered a coercive and forceful act that blocks, manipulates, and controls cross-cultural interaction in various ways (Billiani 2009: 28 ). It suppresses or prohibits speech or writing that is condemned as subversive of the common good (Allan and Burridge in Santaemilia 2008). It can be institutional and personal in practice (Billiani 2009: 29), and exercised by the authority, the editor, or the translator. It takes place in various forms, and is related to complex social, historical, political, cultural, and economic factors. Hence, censorship in translation involves 'multiple agents', such as 'publishers at home and abroad, literary agents selling and buying foreign rights, editors selecting foreign texts and commissioning translators, publishers and their complex links with the political establishment, cultural policy-makers', and 'the translators who operate within a web of constraints and may have their own political and ideological allegiances' (Kuhiwczak 2014: 362).

Censorship has been exercised in China as in other parts of the world, with regard to political, cultural, moral, religious, and economic subject matters. In Chapters Three to Six, the Chinese translations of The Second Sex (TSS) and The Vagina Monologues (TVM) have been examined globally and locally, from lexical choices to sectional rewriting. The examinations have revealed a common phenomenon, i.e. omission of materials concerning lesbianism and prostitution. The omission intimates a kind of censorship of (homo)sexuality. This chapter investigates why censorship takes place in some of the translations and what factors underlie the censorship, and situates the study of the censorship in the broader social, historical, and political context, particularly in the context of the translation publishing industry during the 30 years of reform and opening up when the Chinese translations of TSS and TVM came into being.

\subsection{Censorship, translation, and translation publishing}

To understand censorship in the Chinese translations of TSS and TVM, it is important to know how censorship has been operated, what has been censored, and who the censors are, particularly in translation and publishing in China. All these constitute a backdrop to the censorship operated in the Chinese translations of TSS and TVM and help explain why censorship has occurred in some of the translations. 
China has a long history of censorship. It officially started in the Qin Dynasty (221 B.C.-206 B.C.), a time notorious for 'burning books and executing scholars', because the Qin Emperor Shihuang and his minister Li Shi regarded Confucian scholars and their books as 'a serious threat to the authority of their sovereign'. Since then, censorship has 'never stopped growing', with different scopes, degrees and effects at different times, and has always been used by the governments 'as a favourite tool to vindicate their ruling' (Zhang Wenxian 1990: 61-64, 70). The object of censorship in history ranges from 'the historical record' in the Qin Dynasty; to 'religious books' (Buddhism and Taoism) in the Han Dynasty (206 B.C. -220 B.C.); to 'erotic books' in the early Ming Dynasty; to 'politics', such as books on the history of the Ming Dynasty (1368-1644) and books by the Ming writers opposing the Qing; and to 'obscene books', such as 金瓶梅 [Golden Lotus], in the Qing Dynasty (1644-1911/12). From 1912 to 1949, politics was the major issue of censorship, with 'communism and communists' as its first target, while obscene and religious books were less censored, though sometimes censors 'didn't know very much about what they censored'. For instance, the Chinese translation of Edgar Snow's Red Star Over China, a book 'full of recommendations for the Chinese Communists', was published in 1938 after a change of title to 西行漫记 [A Journey to the West] (Zhang Wenxian 1990: 62-70, Burger 2012: 185-186).

Since 1949, Chinese publishing has been highly regulated, and the Chinese publishing industry has been state owned and state controlled for ideological reasons (Drury 1998: 111-112). The import of cultural products has been monopolised by the government. The exclusive state trading ensures direct government control over the inflow of foreign contents and a maximum level of flexibility and efficacy in the government censorship of imports, with the process of censorship kept non-transparent (Qin 2011: 271-272). From the late 1940 s to the 1970s, no overt censorship was exercised in translation in China since publishing was strictly controlled by the government and texts considered to have problems would not be selected for translation. In post-Mao China, state control is decentralised and overt censorship is exercised in translation and publishing (Chan 2007: 127, Chang Nam Fung 2008: 227).

Censorship in translation and publishing concerns two broad areas: sensitive political issues and explicit descriptions of sex (Chang Nam Fung 2008: 230). Such materials are likely to be cleansed through deletion, attenuation, mistranslation, or denunciation within the text, the title, the preface, or a disclaimer (Chan 2007: 119, Chang Nam Fung 2008: 229-30). China's censorship of Hillary Clinton's memoir Living History is a good example of censorship for political reasons (see Chan 2007). Sex is a taboo and crude topic in China's conservative culture and is not expected to crop up under any circumstances (Lung 2003: 240). As soon as it came to power in 1949, the Chinese Communist Party banned all pornography and erotic fiction. In Mao's regime, every hint of eroticism was extinguished, and the entire topic of sex was shrouded in silence. The late 1970s saw a resurgence of erotica, which the government tried hard to stamp out. Since then, the government has constantly launched the 'Sweeping 
the Yellow' campaigns against pornography and vice (Burger 2012: 185-187). Hence, censorship of sexual material is commonly seen in translation. Translated or otherwise, literary works that contain vivid or explicit descriptions of sex could seldom be published uncensored until the early 2000s (Chang Nam Fung 2008: 233). In translation and publishing circles, there is an unwritten bottom line that descriptions of sexual organs and specific sex acts should not be allowed to remain in the text (Wang Zhisong 2010: 14). Take Haruki Murakami's novel Noruwei No Mori [Norwegian Wood] (1987) as an example. In its two Chinese translations (by Lin Shaohua 1989, and Zhong Hongjie and Ma Shuzhen 1990), references to sexual organs and detailed descriptions of love-making were all deleted to avoid being punished according to relevant rules and regulations (Wang Zhisong 2010: 12).

In China, publishing is subject to post-publication censorship rather than prepublication censorship. Therefore, censorship is imposed more by the publisher than by the government (Chan 2007: 127, Chang Nam Fung 2008: 226). Under post-publication censorship, publishers will be held responsible if they publish something deemed offensive to the leadership (Kahn in Chan 2007: 128). The consequences can be heavy economic losses for the publisher, dismissal of the editorial staff concerned, or even the closing down of the whole house or magazine. Thus, the system of post-publication censorship induces self-censorship by editors. Working under a double tension, publishers try to maximise profits by catering to the tastes of the reading public while trying to stay within the bounds allowed by the authorities. Editors are also found to assume the duty of revising translated texts. Sometimes, they revise the translation without checking the source text or communicating with the translator, depending on the power relations between the two parties (Chang Nam Fung 2008: 235-236).

Translators' self-censorship is often seen, especially in treating sexual materials. Chinese translators have been very cautious in dealing with sexual descriptions in Western literary works in fear of the sex taboo in Chinese culture, and tend not to select works with many sexual descriptions. Such fear is even pervasive among my students. Every year since 2005, I have kept asking my MA students in translation studies whether they would translate TVM if they were approached by a publisher. Many students, especially female students, firmly state that they would not, because if they were to translate it, their reputation would be undermined and they would be considered as having loose morals. Some male students said that they would not, because they were not married yet. When dealing with sexual descriptions, Chinese translators usually euphemise, dilute, summarise, or simply delete explicit sexual descriptions. For example, Zhao Susu diluted and cut some descriptions of sex in her translation of Lady Chatterley's Lover. Most translation scholars are in favour of such sanitisation, due to 'the intolerance of Chinese sexual ethics towards such description' (Han Ziman 2008: 80, Chang Nam Fung 2008: 235, Wang Zhisong 2010: 12 and 14). Editors and translators seldom admit their changes to the text. If they do, it is usually very brief and in an 'obscure' place in the book, such as the 'Translator's Postscript', and probably not to the full extent. In most cases, there is no indication at all 
(Chang Nam Fung 2008: 235). This makes it hard for the reader, especially the researcher, to discern who the censor is when examining and critiquing a translation that has been subjected to cuts and omissions. Consequently, the translator often suffers indiscriminate blame for the editing in the translation, as Parshley, the first English translator of TSS, did.

Although explicit descriptions of sex and sensitive political issues are the two main forbidden zones, the government actually pays more attention to political issues, because political dissent may pose a challenge to the official mirage of 'harmony and stability', bringing a sense of insecurity and loss of face, while face is all-important in Chinese culture, especially to those in power (Chang Nam Fung 2008: 239). That accounts for why explicit sexual descriptions, erotic or even pornographic, can often be seen, especially in literary works, while even an indirect reference to politically sensitive topics may come under censure. It is even more so on the internet, which is an interesting topic to be explored. A case in point is the censorship exercised by the publisher to Chang Nam Fung's book 中西译学批评 [Criticism of Chinese and Western Translation], an academic work published by an academic press. In the book, there is one chapter on a case study of David Lodge's Small World, which contains examples of explicit sexual descriptions (see Examples 1-2 below) and another chapter on Chinese translation tradition, which cites examples of political issues (see Example 3 below).

1 ST: Is it really twenty-five centimeters?

TT: Ni de xingyu zhende feichang qiang ma?

[Is your sexual desire really very strong? $]^{1}$

(Lodge in Chang Nam Fung 2008: 234)

2 ST: Didn't you make your wife measure it with her tape measure?

TT: Ni meiyou baonüe guo ni de qizi ma?

[Have you never violated your wife?]

(Ibid: 234)

3 The arrest of a dissident is not unusual in China, and Harry Wu's imprisonment might have received scant attention in the American media. But China had been chosen to host the upcoming United Nations Fourth World Conference on Women, and I was scheduled to attend as honorary Chair of the U.S. delegation. Wu, a human rights activist who had spent nineteen years as a political prisoner in Chinese labor camps before emigrating to the United States, was arrested by Chinese authorities on June 19, 1995, as he entered Xinjiang Province from neighboring Kazakhstan.

(Clinton in Chang Nam Fung 2008: 230-231)

Examples 1 and 2 are two questions that Fulvia Morgana asks Morris Zapp in Small World. These two examples illustrate how the sexual descriptions are attenuated in the Chinese translation. Although the English examples contain 
explicit sexual content, the case study chapter 'has slipped through the hand of the editor'. By contrast, the chapter containing Example 3 (and other such examples) is deleted. Example 3 is the beginning of the original example which is a long quotation from Hillary Clinton's memoirs Living History. The underlined parts are deleted in the Chinese translation. Living History is critical of China's human rights record and thus has been extensively expurgated in its Chinese translation published in the Mainland. This example shows how the text is sanitised by deleting 'nocuous' parts. Such examples are believed to be unpublishable (Chang Nam Fung 2008: 230 and 238).

Sometimes, the operation of censorship can be rather arbitrary, depending not only on the likes and dislikes of those in power, but also reflecting a fair degree of randomness. The fate (the banning and unbanning) of Lady Chatterley's Lover in China has to some extent shown that sex itself is not the key issue of censorship. Market competition underlay its banning in 1987, with the sexual content as a good excuse. Seeing the popularity of Lady Chatterley's Lover, the director of a book store regretted having turned down the order. He wanted but failed to regain the order. He then wrote a letter to a superior, reporting the publication of Lady Chatterley's Lover by Hunan People's Publishing House. This secret and base report led to the banning of the work and punishment of the relevant staff. However, the chief editor could have suffered more severe punishment if another superior had not found Lady Chatterley's Lover in an exhibition of obscene publications and disagreed with categorising the work as obscene. An even more absurd story is that Lady Chatterley's Lover was once misunderstood by a superior in the Hunan Publishing Bureau as Mrs. Thatcher's Lover, who then criticised the publisher, saying that such a book should not be published as it may influence the relationship between China and Britain (Chen Xiaoping 2008, also see 7.2.1).

\subsection{Translation publishing from 1980 to 2009}

During the decade of the Cultural Revolution (1966-1976), the publishing industry suffered serious restrictions. Most of the publishing houses were paralysed, either being closed down or switched to other functions with the editorial staff transferred to do manual labour (Tian Zhiling and Zhang Hao 2008). In such circumstances, translation publishing almost stopped. Almost all translators were 'overthrown', and translation was under the strict 'control of power and ideology'. Only a limited number of works was selected for translation for '内部发行' [internal distribution] instead of '公开发行' [public distribution] (Xie Tianzhen 2009: 23-24). Such books were usually intended for high-ranking officials and some specialists. Most Chinese people were deprived of access to them. Once such a book was lent out, it was often passed from one person to another and became worn out after going through innumerable hands. In the 1970s, it was often these worn-out copies of (mostly partial) translations that provided ideological resources and incubated underground cultural trends (Dai Jinhua 2007: 37). 
China started its reform and opening up in the late 1970s when the Cultural Revolution ended. The turn of 1980 witnessed the unfreezing and all-round rapid development of the publishing industry in China. Since 2008, almost in every field, reviews have been made of what has happened or has been achieved in the past 30 years of China's reform and opening up. One common way is to roughly divide the past 30 years into three periods and take stock of the major events or achievements in each decade. Each of the three decades has its own features in translation publishing, which can be generally summarised as: the revival and fluctuation of translation publishing from 1980 to 1989, the depression and reformation of translation publishing from 1990 to 1999, and the market-oriented development of translation publishing from 2000 to 2009 ( $\mathrm{Li}$ Jingrui 2008a and 2008b, Wu Xusheng 2009). Except for the translation by Zheng Kelu (2011), the existent Chinese translations of TSS and TVM were published from 1986 to 2009, within the time frame of the three decades. Hence, the periodisation is very useful for looking into the censorship exercised in the Chinese translations of TSS and TVM, because the fate of each of the translations is closely related to the ups and downs in translation publishing from 1980 to 2009 , in addition to other factors.

\subsubsection{Revival and fluctuation from 1980 to 1989}

The Cultural Revolution resulted in a special period of book shortage until the beginning of the 1980s. The policy of “解放思想' [emancipating the mind] and the ensuing thirst for books led to the decision by the State Publication Bureau to rush out Chinese and foreign literary masterpieces. Many publishers dug out the Chinese and foreign masterpieces that they had accumulated and reprinted them to meet the urgent demand from readers (Anonymous 2008). That is to say, the publishers first reprinted already published books and then made plans to publish new books (Tian Zhiling and Zhang Hao 2008), just as was the case for TSS, new translations of which came out later one by one after the first reprinted version.

Massively reprinting Chinese and foreign classic masterworks was accompanied by an upsurge of translating and introducing Western classic academic books and the most popular foreign light-reading books. As far as academic books were concerned, an array of foreign books in the social sciences sold very well, including Being and Nothingness by Sartre (1987) and The Interpretation of Dreams by Freud (1987), 150,000 copies of each being sold (Wu Xusheng 2009). During this period, Western theories of all kinds, including feminism (such as TSS), generated a great deal of attention and enthusiasm in China, especially among Chinese scholars and students of literature. As a result, roughly 50 or 60 years' worth of Western theories were introduced to Chinese readers in a short span of 5 or 6 years. All these theories found themselves both much desired by Chinese readers and "potentially dangerous as "spiritual pollutants" in the Chinese political atmosphere' (Zhang Longxi 1998: 155-156). Consequently, successive waves of political campaigns against Western 'spiritual pollution' and 
'bourgeois liberalisation' punctuated a period of recent Chinese history since the end of the Cultural Revolution. The 'spasmodic rhythm' of the political campaigns led to ups and downs in translation publishing, especially in the 1980s (Zhang Longxi 1998: 153).

The Central Party's policy of '拨乱反正' [setting things to right] did relax control of translation publishing after the Cultural Revolution. Nevertheless, translation publishing continued to encounter resistance due to the continued influence of 'leftist' thought at some levels and a discrepancy of value judgment resulted from some people who looked at new things with an old view formed in the coercive period of the Cultural Revolution. In 1980, the government launched 'an aggressive attack' against 'spiritual pollution', 'an amorphous term that let the government go after anything it perceived as threatening' (Burger 2012: 185-187). In 1983, publishing houses were required to check the translations published since 1980 ( $\mathrm{Li}$ Jingrui 2008b), and a number of foreign classics reprinted from 1980 were listed among the ‘精神污染之作' [spiritual pollutants] (Anonymous 2008). ‘黄皮书' [yellow cover books] of restricted publication served as '反面教材' [negative teaching material] were regarded as spreading mental pollution and encouraging liberalisation. ${ }^{2}$ Even 'Sartre fever' was criticised. In consequence, some publication plans had to be stopped, and publishers would not run the risk of publishing translations of modern political and academic works (Li Jingrui 2008b).

This regressive tendency was soon 'corrected' (Anonymous 2008) and did not stop the processes of reform and opening up (Zhang Yin and Huang Min 2006). At the end of 1983, Hu Yaobang (General Secretary of the CPC Committee from 1981-1987) stressed that a clear distinction had to be drawn between works of spiritual pollution and works of value. As for translation publishing, he pointed out that generally recognised world classics should not be banned. It did not matter even if there were some erotic descriptions in famous novels by bourgeois writers. What ought to be banned were writings purely concerned with sex. The spirit of his speech being implemented, translation publishing increased rapidly in category, variety, and number of copies (Li Jingrui 2008b).

One consequence is the publication of 'sex books'. Before 1978, China was a '无性社会' [sexless society], and sex 'disappeared from the realm of cultural expression'. During the Cultural Revolution, class struggle was the major task, while public discussions of sex and romance were considered bourgeois and became taboo (Pan Suiming in Dai Shuang 2008, Pan Suiming 2006: 17). With the deepening of reform and opening up, Western 'sexual liberation' and 'sexual freedom' spread to China, and Chinese people's minds, which had been shackled for a long time, were gradually liberated (Liu Shengquan 2009: 27). Once sexual repression was released, the quest for sexual knowledge exploded (Dai Shuang 2008). In the 1980s, the richest source for sex education was books (Chen Xiaoping 2008). At that time, many books on sex were published, such as 性医学 [Sexual Medicine] by Wu Jieping (1982), 情爱论 [On Love] by the Bulgarian Orlin Vasilev (1984), ${ }^{3}$ 性知识手册 [A Handbook of Sexual Knowledge] by Ruan Fangfu (1985), 中国娼妓史 [A History of Prostitution in China] by 
Wang Shunu (1988), and 人类性生活史 [A History of Human Sex Life] by Zhu Yunying (1988) (see Wang Yi 2001, Anonymous 2008, Li Jingrui 2008b, Liu Shengquan 2009: 27). What is interesting is that the 1988 Chinese translation of TSS was also listed among 'sex books' (Wang Yi 2001). These books started modern sexual education in China, making dramatic contributions to removing the mystery of sex and sexual ignorance and to enjoying sexual pleasure and sexual health (Liu Shengquan 2009: 27).

High demand and prospective profit resulted in '性书热' [sex book fever] in publishing. In the mid- and late 1980s, the threshold for publishing translations was lowered. At that time, foreign literary and artistic books were very popular, and publishers and booksellers flocked to such books for profit. Large numbers of foreign literary and artistic books were translated and published, including books featuring hard pornography and violence, such as 玫瑰梦 [Rose Dream] by Jackie Collins and 暴力与色欲 [Violence and Lust] by Nishimura Juko. 'Jackie Collins fever' appeared in 1987, followed by 'Nishimura Juko fever'. With its provocative cover and vulgar content, 玫瑰梦 [Rose Dream] was regarded as representative of obscene books and later was at the top of the list of banned and confiscated books and magazines (see Anonymous 2005). Thirty-five novels by Nishimura Juko had been published before the banning of obscene publications started. Many of them feature sexual violence and sexual perversion. Vulgar translated (and domestic) books containing sex and violence were sold everywhere in bookstores and bookstalls (Anonymous 2008, Li Jingrui 2008b, Wu Xusheng 2009).

In response to what the government saw as a dangerous excess, a campaign was launched to suppress obscene publications. In 1985, new anti-smut regulations were announced: 'Pornography is very harmful, poisoning people's minds, inducing crimes [...] and must be severely banned.' In 1988, more antipornography regulations were signed into law at the National People's Congress, with higher fines and longer prison sentences. In the same year, Deng Xiaoping, the paramount leader of the People's Republic of China from 1978 to 1992, was quoted in the Chinese media as even saying that some publishers of pornography should be put to death. In this massive campaign, 'tens of thousands of erotic books and magazines were confiscated in city after city' (Burger 2012: 186-187). In 1987, Lady Chatterley's Lover was banned upon being printed, a reprint by Hunan People's Publishing House of the 1936 translation by Rao Shuyi. The director and vice-director of Hunan Publishing Bureau and the president of the publishing house were all punished and given a warning by the Party. The chief editor was removed from his position (Chen Xiaoping 2008). ${ }^{5}$ In little more than a year from April 1988, over 100 publications were banned or confiscated due to obscene or sexual content or for other reasons (see Anonymous 2005 for the list of banned books and periodicals since April 1988). In 1989, publishing circles started to rectify the liberalisation tendency in publishing translated works and the anarchy in introducing Western culture that appeared from the mid-1980s (Anonymous 2008, Li Jingrui 2008b). 
All this must have made the publishers in the late 1980s more careful with their publications. For example, seeing Lady Chatterley's Lover banned, Lijiang Publishing House cautiously put off its plan for publishing Lolita, and when publishing it in 1989, the editor censored some detailed and explicit sexual descriptions according to '关于认定淫秽及色情出版物的暂行规定' [Provisional Regulations for the Identification of Obscene Publications] issued by the State Press and Publication Administration in 1988. The regulations provide detailed rules, such as no descriptions of homosexuality or sexual perversion and no descriptions of sexual crimes (Zhang Yin and Huang Min 2006). In spite of the self-censorship, Lolita was still banned later (Liu Shengquan 2009: 27). Nowadays, the provisional regulations are still used in the press and publishing industry, and most of the publishing houses observe the regulations when editing their publications (Zhang Yin and Huang Min 2006).

\subsubsection{Depression and reformation from 1990 to 1999}

In the early 1990s, a series of events gradually brought translation publishing to its nadir. First, the rectification of liberalisation in translation publishing which started from 1989 led to strict control on publishing translated works. Then in October 1991, the Copyright Law of the People's Republic of China came into effect. One year later in October 1992, China acceded to the Berne and the Universal Copyright Conventions (Drury 1998: 116). These two events meant that the publisher had to get permission to publish copyright works. At the beginning, some publishers did not know how to buy the copyright, or were not willing to part with their money for the copyright. This could be the reason why it took so many years for Tao Tiezhu to get his 'complete' translation of TSS published. He had already finished his translation in 1990, but it was not published until 1998 with the publisher's help in dealing with the copyright (Chen Huan 2004). At the same time, '读书无用论' [the idea of uselessness of study] came to prevail. The strong desire for books all over the country in the 1980s no longer existed. These factors led to the number of translations published falling precipitously in 1993 (Anonymous 2008, Li Jingrui 2008b, Wu Xusheng 2009). According to Liu Xiantao (1999: 105), the number of translated books published in 1989, 1990, 1991, and 1992 are 2240, 2060, 1951, and 2202 respectively, but only 698 in 1993.

Yet from 1994, the publishing industry, as well as many other industries, started to transfer towards a market economy, or what was officially called 'socialist market economy' in China. Translation publishing ushered in another run of rapid development geared to the market, leading to the dramatic increase of the total number of translations. Big profits engendered unprecedented 'translation publishing fever'. Translation publishing became more open. For example, in 1995, for the first time there came two uncensored Chinese translations of Ulysses, a contemporary classic which aroused much controversy in the West. This is regarded as an important signal of China persisting in opening up (Li Jingrui 2008b). 
Although translation publishing was depressed in the early 1990s, the Fourth World Conference on Women held in Beijing in 1995 created a good environment for Western feminism to come to China. The 1990s witnessed an influx of Western feminist works, which continued into the next decade. The feminist works translated and published in this period include Moi Toril's Sexual/Textual Politics: Feminist Literary Theory [性与文本的政治一女权主义文学理论] (1992), a retranslation of Betty Friedan's The Feminine Mystique [女人: 走出陷阱] (1992), Mary Wollstonecraft's A Vindication of the Rights of Woman [女权辩护] (1995), John Stuart Mill's The Subjection of Women [妇女的屈从地位] (1995), Kate Millett's Sexual Politics [性的政治] (1999), and Susan Alice Watkins's Feminism [女性主义] (1999) (Huang Lin 2006: 80, Huang Lin and Zhuge Wenrao 2007: 88). Tao's 1998 'complete' translation of TSS is also among the list.

\subsubsection{Market-oriented development from 2000 to 2009}

A more market-oriented economy has promoted the growth of translation publishing while it has also given rise to many problems, such as the degradation of translation ethics, dishonesty, and disorderly competition. The specific problems in translation publishing include partiality of particular types of works imported, degraded translation quality, heavily duplicated publication, lingering plagiarism after repeated banning, continued rampant piracy, lack of book reviews (especially on imported books), lack of guidance, and lack of necessary monitoring of translation qualifications (Li Jingrui 2008a). Many foreign literary classics, for example, have been duplicated in low quality but large quantity, because they are no longer copyright books. There is no need to buy copyright for these kinds of books, and there is a stable readership for them. Therefore, both retranslations and reprints posing as retranslations have appeared. Some works have even had ten to twenty so-called 'retranslations', such as The Red and the Black, The Lady of the Camellias, Pride and Prejudice, and Lolita. Some such retranslations are simply previous translations with slight changes, often using a false name for the translator, like the two 2009 Chinese translations of TSS. This kind of retranslation used to be produced by shady booksellers, but now some regular publishing and printing houses have also been found to be doing it. Some publishers have brought out around 100 retranslations of classics in a year (Li Jingrui 2008a). Perhaps a typical example is Beijing Yanshan Publishing House. This publishing house has published a series of 'translations', some of which, such as The Scarlet Letter, have been found to be simply 'copied translation', i.e. reprints of previous translations but circulated as new translations (Shenzhen Fanyi 2009a and 2009b, Anonymous 2010).

\subsection{Censorship of sexuality and the Chinese translations of The Second Sex}

The global and local examinations of the Chinese translations of TSS in Chapters Three, Four and Six have indicated what is omitted and why. The omissions 
examined actually indicate no deliberate deletion of the sexual content in the translations, with the possible exception of the 1988 translation of Book II by Wang Youqin and Qiu Xichun et al., in which two whole sections on 'abnormal' sexuality are deleted: 'The Lesbian' and 'Prostitutes and Hetairas'. The reason has been briefly discussed in 3.2. But why were materials cut in the 1988 translation kept intact in the 1986 translation by Sang Zhuying and Nan Shan and in the 1998 'complete' translation by Tao Tiezhu? This has much to do with the special circumstances of the time, especially the ups and downs of translation publishing in the 1980s, resulting from the ups and downs of 'emancipating the mind' (Li Jingrui 2008b).

As mentioned in 7.2.1, the environment of translation publishing was very relaxed in the mid-1980s after the then General Secretary Hu Yaobang instructed that world classics should not be banned due to erotic descriptions. This is one of the factors for the 1986 version remaining intact. Another reason could be that the 1986 version is a reprint from a Taiwan translation to meet the urgent need of readers. The publisher did not need to be responsible for the 'problems' of a reprinted book. However, the government soon saw dangerous excess lead to 'sex book fever' and launched a campaign to suppress obscene publications with the 'Provisional Regulations for the Identification of Obscene Publications' issued in 1988, which bans descriptions of homosexuality. This largely accounts for the deletions of the lesbian and prostitute chapters in the 1988 retranslation of Book II, in addition to the social attitude towards lesbianism and prostitution. From 1994, 'socialist market economy' led to the rapid development of, and more open, translation publishing ( $\mathrm{Li}$ Jingrui 2008b). The changing social circumstances allowed for a complete translation of TSS. The 1998 'complete' translation came 3 years after the Fourth World Conference on Women was held in Beijing, which created a favourable environment for the import and reception of Western feminist theories. Tao Tiezhu (1998: 2) explained in his translator's preface that he translated TSS in order to meet the needs of women's studies in China. Thus, in this translation, not only are no large sections omitted, but also no words or sentences are deleted in the descriptions of the female body, female sexuality, and lesbianism (analysed in Chapters Four and Six).

By and large, it can be concluded that there is a lack of censorship of sexuality in the Chinese translations of TSS. Since the explicit description of sex is one of the two main forbidden zones in China, we might ask why the translators or editors did not try to 'sanitise' the work, and why such a work of a 'strongly sexual' nature (Fallaize 1998: 8) has never been banned, despite being regarded as 'disturbing' even in the West (Millett in Forster and Sutton 1989: 20), being on the list of 'sex books' in the 1980s in China, and which is still regarded as avant-garde in present-day China due to its sexually explicit content (Wang Yi 2001). Rather, it has travelled smoothly in China. Explanations vary. In addition to the factors already discussed, there are other important reasons.

One very important reason is Beauvoir's identity as Sartre's 'wife' and Beauvoir's rapport with China. The reform and opening up from the late 1970s, especially the emancipation of the mind, provided a favourable condition for Western 
theories coming into China. The arrival of Beauvoir's TSS is regarded as marking the arrival of European and American feminism. Ironically, its arrival and subsequent popularity was not so much due to its feminism as to the introduction of Sartre and existentialism. Sartre was one of the very few non-Marxist thinkers introduced and translated through the mainstream channels in China in the 1960s. In the 1970s and 1980s, Sartre and existentialism became popular in universities (Dai Jinghua 2007: 37). Due to the rise of existentialist thought in China, as a representative existentialist writer Beauvoir was welcomed by literary circles, and her works were translated and interpreted from an existentialist perspective. The death of Sartre in 1980 brought about a surge in Sartre studies and also enhanced interest in Beauvoir studies (Luo Ting and Wang Fang 2004: 126), because Beauvoir had been well known as Sartre's life-long partner, the 'wife' of a great man, and the woman behind the great man. Although Sartre and Beauvoir were never married, Beauvoir was referred to as the wife of Sartre in the earliest introduction to Sartre (Dai Jinghua 2007: 38). The unmarried relationship between Sartre and Beauvoir was especially fascinating to Chinese readers, and their life was described as a love myth, through which Chinese readers got to know a new life pattern of Western intellectuals. Chinese urban readers, especially professional and intellectual women, idealised and romanticised the life of Sartre and Beauvoir so as to relieve the double pressure from family and career caused by society running at an increased speed (Huang Lin 2006: 79). Besides Sartre and existentialism, Beauvoir's pro-China view should have played a role in the smooth travel of her works in(to) China. As early as 1955, Beauvoir and Sartre visited China for over a month at the invitation of then Premier Zhou Enlai. After this visit, Beauvoir published La Longue Marche [The Long March] (1957), in which she not only introduced the politics, economics, culture, and cities of China, but also refuted some anti-China and anti-communist views in the West at that time (Luo Ting and Wang Fang 2004: 126). Undoubtedly, this helped lay a good foundation for the reception of her works in China. Therefore, TSS (and her other works) experienced little difficulty in entering China, and its translations have experienced little censorship of sexuality.

Beauvoir's naming women as the second sex is an important reason for the popularity of TSS upon its arrival in China, because it reflected the experience of Chinese women as an invisible gender in society (Dai Jinghua 2007: 38-39). Chinese urban women in the 1980s were in theory equal to men at the political, economical, and legal levels created by the socialist system. To some extent, what women intellectuals faced was not “公然的性别歧视' [open gender prejudice] or '针对女性的社会放逐' [social exclusion against women], but the delicate double standard or double role under seemingly absolute equality. In other words, women faced the heavy burden of a male standard of work in society and a concealed expectation of being “贤妻良母' [a good wife and virtuous mother] at home. The campaign of emancipating the mind at the turn of the 1980s showed a tendency to reconstruct a patriarchy-centered gender order, and Chinese women's political and social status deteriorated with the economic reform. Beauvoir's naming women as the second sex struck a chord among 
Chinese intellectual women and prompted them to reflect on their own experiences as the 'second sex'. Chinese feminists of the 1980s made use of 'women, the second sex' to mark the existence of gender differences so as to break through their invisibility in this period of 'men and women are the same', and to cultivate women's consciousness as being essentially different from men's. The 1986 reprint of the Taiwan translation, though only a translation of Book II, not only echoed but also helped construct the initial orientation of contemporary Chinese feminism, which is 'more cultural than political' (Dai Jinghua 2007: 38-39, also see Dai Jinghua 1999).

Li Xiaojiang (1999) has a slightly different opinion on the popularity of TSS in the 1980s. She argues that naming women as the second sex was not novel to Chinese readers because women had been long oppressed and enslaved. What makes TSS appealing is the word 'woman' added to the title of the 1986 translation, because the word 'woman' was especially refreshing to Chinese people who had just come out of the Cultural Revolution, during which China had been a society of 'men and women are the same' (which actually made women disappear). She contends that the added 'woman' was challenging a society where women had been lost (Li Xiaojiang 1999: 98, also see Li Xiaojiang 2006). She has a point here. As one of the pioneers in women studies in China, doing research on women's issues in China in the 1980s, Li Xiaojiang had known very well the problems of Chinese women. Naming women as the second sex was certainly not novel to her and other relevant researchers, but this did not necessarily apply to general Chinese readers.

Mao's statement 'Men and women are the same' was made in 1964, and published in the People's Daily a year later. It was a time when the 'push for male-female equality was strongest' and 'the boundaries separating the sexes were overridden by the movement of women into men's works and political activism' (Mann 2011: 49). Such equality between men and women actually deprived women of their difference, and androgynised women, which somehow gave the illusion that Chinese women were liberated and enjoyed an equal position to men. Many Chinese (men) still hold this view today. Ai Xiaoming said she often heard people saying 'Chinese women have been well liberated' (Zhang Qi and Pang Minghui 2003). I also heard such remarks in a dialogue between a Chinese young couple in their late twenties who were both pursuing their $\mathrm{PhD}$ studies in the UK. The man told his girlfriend, 'Be contented! Chinese women have been enjoying much better equality [than women from other countries]'. Few Chinese in the 1980s had gender awareness and would connect 'the second sex' with women. For general readers, the first or major function of the added 'women' was to make it clear that The Second Sex was a book about women. I still remember that I felt completely in the dark at the first sight of the title '第二性' [The Second Sex], and could not tell from the title itself what the book was about. Nord (1995: 274) rightly points out that 'the phatic function of a title depends on its length and its mnemonic quality, which is often strengthened by the use of familiar title patterns'. This may also be the reason why the 1988 retranslation of Book II was renamed as '女人是什么' [ What is Woman?]. It has 
been mentioned in the last section that Chinese people of the 1980s had just stepped out of a sexless time, and books about women (and sex) were particularly appealing to readers at that time. According to Dai Qing, a well-known Chinese female writer, 'What readers see is sex and not feminism. [...] Chinese people are quite ignorant about things going on in Western post-industrial societies, such as homosexuality and feminism' (Wang Zheng 1993: 193). Hence, in the 1980s 'women' was often used as a 'selling point' (Cheng Hongwu 2013: 33). Whatever the reason, the 'women' added in the title did seem to have contributed to the popularity of the 1986 translation and the other translations of the 1980s.

What Huang Lin identifies in the partial translations of the 1980s is the power of translation and publishing. She argues that it reflects a consideration of the need and reception of Chinese readers, or as it were, a consideration of the survival of feminism in the Chinese context. To her, 'the second sex' is not only an important naming, but a term that could be immediately understood in the Chinese context. Compared with Book I, which is a deep analysis of the Western cultural background, Book II is more comprehensible. The difficult situation of women that it focuses on is very similar to the difficult situation Chinese women were facing, an issue that Chinese women writers were discussing. This underlay the immediate popularity of its Chinese translation and fostered the development of Chinese feminism (Huang Lin 2006: 79).

The two 1988 Chinese translations of TSS (Book I and Book II) came together with the Chinese translations of two other early feminist English writings: The Feminine Mystique by Betty Friedan (1963) and The Golden Notebook by Doris Lessing (1962). This represents a good reception of Western feminism in China, although the lesbian and prostitute chapters were cut in the 1988 Chinese translation of Book II of TSS. Dai Jinghua (2007: 40) summarises three reasons why Western feminism did not encounter a direct attack or an official ban in China in the 1980s:

(1) Promoting and practising women's liberation has been one of the important and basic social policies of the People's Republic of China. Hence, Western feminism did not seem very alien. The translation of and introduction to early European and American feminist works did not exhibit a radical political complexion of feminism.

(2) Although the process of reconstructing a patriarchy-centered gender order potentially began in the 1980s, some sense of morality and honour prevented male elitist intellectuals, who had previously called for 'liberation' and promoted 'progress', from openly expressing hostility and refusal towards feminism.

(3) As a European-American theory, feminism has a 'natural' authority and truth which protected feminism in China in the 1980s. Beauvoir and feminism surfaced in 1988 due to the translation, introduction, and discussion of Euro-American feminist theories and practices over 10 years, which was also a direct feedback on and counterattack to the looming rehabilitation of patriarchal culture. 
The English source text of the Chinese translations is another important reason for the lack of censorship of sexuality. Although TSS contains sexual content, the Chinese translations are based on the censored English version, in which references to cultural taboos (such as lesbian relationships) and unwelcome realities (such as the tedium of women's everyday lives) are toned down or deleted (Simons 1983: 561, Flotow 1997: 50, Moi 2002: 1009). Since the source text of the Chinese translations is more or less an already sanitised version, further censorship of sexual material may have been unnecessary or difficult. What is more, just as discussed in 7.2.1, sexual views of Chinese people have become much more open since the 1980s (Liu Shengquan 2009: 27). TSS does not impose as much of a shock in terms of sex as it does in terms of how women are constructed and oppressed in a patriarchal culture.

Sales considerations could also have played a role since sexual content can always be a selling point for publishers, whether in America or in post-Mao China. The wife of the American publisher became interested in the book due to its sexual content, thinking that it was a 'highbrow sex manual' (Thurman 2009/2010: xiii). It might be true for the Chinese publishers too. Just as the early editions of the English translation often had nude women on the cover with a sort of mischievous cachet (Millett in Forster and Sutton 1989: 20), most of the covers of the Chinese translations have either a picture of a naked woman, or a picture of a woman's bust, with strong sexual implications. No doubt this kind of illustration can make a big academic work seem less daunting to general readers.

\subsection{Censorship of sexuality, and the Chinese translations of The Vagina Monologues}

The favourable reception of TSS in China and the lack of censorship of sexuality in the Chinese translations discussed above form a sharp contrast with the progress of TVM in China, as TVM has encountered much more censorship regarding the script and resistance to its productions. The fact that no Chinese translation of TVM has been published in the Mainland represents a kind of institutional censorship in the first place, not to mention the banning of its productions in Shanghai and Beijing in 2004. The global and local examinations of the three Chinese translations in Chapters Three, Five and Six have shown that censorship of sexuality takes place in the two Mainland translations. Yu Rongjun and Ai Xiaoming both omit the follow-up interview of the 'woman who loved to make vaginas happy', removing the erotic description of lesbian sex not suitable for the stage, and Ai Xiaoming goes further to rewrite the lesbian story in the monologue 'The Woman Who Loved to Make Vaginas Happy' into a Chinese heterosexual moaning story, turning the homosexual moans into heterosexual ones. This intimates that the translators' self-censorship is more or less directed at the lesbian content. This self-censorship seems somewhat unusual when taking into consideration the content of the play and the time the translations came out. Since the piece is of a very sexual nature, what 
difference does it make to cut a short section of explicit description of lesbian love? This is deeply entangled with the institutional and public attitudes towards homosexuality.

Attitudes towards homosexuality are a complicated topic because of the dramatic differences in ancient China and modern China. Burger (2012: 123) claims that 'no country has as rich and unusual a history of homosexuality as China', and that 'more tolerant of same-sex love than nearly any other society', ancient China can be regarded as a 'golden age' of same-sex love, though some eras were more tolerant than others. The word 'homosexuality' did not exist in ancient China, because homosexuality was 'not a life style choice or an identity or something that could be explained psychologically as it is in the West', but a 'natural' behaviour, practised by the nobility, the literati and wealthier merchants who were heterosexual or bisexual and often married. The only sin of homosexuality from the perspective of traditional China was that men would likely not provide their parents with grandchildren. The word 'lesbian' did not existed either. Romantic feelings between women, such as those living together as concubines or servants, were classified as 'sisterhood', not lesbianism. Although same-sex love between women was 'perfectly fine' under Daoism and 'even expected because they lived together in close quarters', female same-sex love was rarely celebrated publicly as was male same-sex love. British colonisers imposed homophobic laws after the Second Opium War and Christian missionaries brought Western values to China. Homoerotic behaviour was reclassified as a psychological disorder in the early twentieth century. The spirit of homophobia 'continued and accelerated', and by the time of 1949 most Chinese people viewed same-sex behaviour as 'deviant behaviour'. The establishment of the People's Republic of China in 1949 started 'the dark days for homosexuality in China'. Seen as a form of 'spiritual pollution', homosexuality 'in any form' was banned. No references to same-sex love can be seen in literature and art from the 1950s to the early 1980s. The notion of homosexuality was erased from the public consciousness, and the 'illustrious history of homosexuality in the times past' was kept unknown to most Chinese. Homosexuals were forced underground, because those who met in public places (such as public parks and toilets) ran a great risk of being arrested and even imprisoned (Burger 2012: 123-138). Because homosexuality was rarely discussed in China's press or in routine conversations, most Chinese never knew anything about homosexuality and did not believe it even existed in China. Even today, most Chinese people are still ignorant of homosexuality and millions of people believe that homosexuality is something imported from the West.

During the Cultural Revolution, homosexuals were subject to criticism; many were branded as class enemies; and some were beaten to death. Until 1997, homosexual acts were regarded by law as 'hooliganism', 'a broad, amorphous term that could apply to any type of social offenses'. Not knowing the actual laws, gays were in a constant state of fear and confusion. The penalties homosexuals faced ranged from prosecution for the crime of hooliganism, to a warning, to stigmatisation, to notifying the families, to demotion or dismissal, which forced 
them to live with 'nearly unbearable shame and isolation' (Burger 2012: 135-136). Under such circumstances, the Chinese had no understanding of homosexuality anymore, including the homosexuals themselves, who perceived it as a disease to be shunned or believed there was something wrong with it. Records of the penalties are mostly about gay men, with very few involving lesbianism, perhaps due to the reason that lesbianism was more invisible or closeted (Sang 2003, Burger 2012). Research on lesbian lives is also very scant in Mainland China (Leung 2002: 129). According to Li Yinhe, Chinese people are more tolerant of lesbianism, because China is a very patriarchal and traditional society that overlooks women in some ways but regards it as shameful for a man to be gay (Burger 2012: 147, also see Sang 2003: 6-7).

As discussed in 7.2.1, China stepped from being a society where sex was completely taboo into a mind-liberated one in the 1980s, under the influence of Western sexual liberation and sexual freedom, and 'sex book fever' appeared as a source for sex education. In 1985, a popular Chinese health magazine 'took the unprecedented step' of publishing an article about how homosexuality exists in all cultures and nations, and argued that gays should not be discriminated against (Burger 2012). In 1991, homosexuality was no longer regarded as a crime of hooliganism and was decriminalised in 1997, though there are 'no explicit legal protections for gay rights' (Dai Shuang 2008, Mann 2011: 196). The cosmopolitan lesbian subject became visible in the late 1990s, but Mainland lesbians do not have 'the same kind of public media presence that gay men have' (Sang 2003: 171 and 173, Cui Zi'en 2008). Lesbians are less visible in contemporary China, partly because female same-sex relationships are often uncritically linked with notions of friendship and sisterhood (Ho 2008: 496, Sang 2003: 3). In 2001, China redefined psychosis, and homosexuality was no longer defined as a disease (Zheng Shuhua and Tian Liping 2001, McMillan 2006: 93). In 2003, Li Yinhe proposed the legislation of homosexual marriage to the National People's Congress and Chinese People's Political Consultative Conference, which created a sensation both within and outside China. She has proposed it each year since then and is determined to carry on until it is legislated (Dai Shuang 2008). The two Mainland translations of TVM both came out in 2003, when the institutional and public attitudes towards homosexuality had much changed. A survey in 2008 of the public's attitude towards homosexuality by Li Yinhe (2008) shows that people of higher social position and of younger age are relatively permissive towards homosexuality. These facts indicate that Chinese culture is slowly becoming more tolerant of sex and homosexuality.

Nevertheless, with all these changes in attitudes towards sex and homosexuality, 'same-sex sexual contact still carries the weight of strong social disapproval' (McMillan 2006: 93), as the government has since 1949 'taken dramatic and coercive steps to ensure that a normative heterosexual model of marriage and carefully regulated reproduction keep the population productive and growing, at the right pace and with the right quality' (Mann 2011: 193). This official conflation of sex with marriage excludes premarital and homosexual relationships from the appropriate legal protection offered to the heterosexual marital unit 
(Sigley 2006: 49). Homosexuals are still facing misunderstanding and prejudice from mainstream society (Li Yinhe 2006a: 99). The general public, especially those who are older, of lower social position and poor education, and live in smaller cities and rural villages, are still less permissive towards homosexuality (Li Yinhe 2008). Many Chinese people still hold a very backward view towards sex (Li Yinhe 2006b). Sun Haiying, a famous film star in China, once made a very extreme remark on homosexuality. He regards homosexuality as 'a destruction of humanity' and 'a betrayal of human nature', which is 'disgusting', 'a crime', and 'should not be mentioned' at all (Cui Zi'en 2008). What he said sounds very similar to what a 'fervent nationalist' said in the late 1990s: 'We won't have homosexuality in China! We should eliminate homosexuals!' (Chou Wah-Shan 2001: 63) Such homophobia is still very pervasive in China.

The public's attitude towards homosexuality must have influenced the translators' decision-making in the process of translation. Yu Rongjun translated the play for commercial production. Ai Xiaoming organised the translation and production as a part of her course to educate her students and to extend the influence to the public. Therefore, their translations are all targeted at the public. They may have removed the explicit description of homosexual love to reduce potential resistance to their productions since the title itself already carries a great 'shock value' (Kahn 2004). Such self-censorship can be regarded as a 'censorship avoidance strategy' to 'prompt new forms of artistic expression' (Kuhiwczak 2014: 361).

Yu's translation of the lesbian monologue is basically close to the source text, keeping the exotic content. This reflects his gesture of keeping distance from the lesbian content. It is safer to translate foreign lesbian stories than to supplement them with Chinese lesbian stories that may bring trouble to him, given the public's view of homosexuality in China. In comparison, Ai Xiaoming appears somewhat bold to turn the Western lesbian sex worker's story into a Chinese moaning story. However, she removes the lesbian sexuality in 'The Woman Who Loved to Make Vaginas Happy' and turns the lesbian moans into heterosexual ones, which reflects her consideration of the social and institutional response to homosexuality. She self-censors it to ensure a better reception of her production. It seems her self-censorship has helped in achieving her aim to spread feminism to Chinese audiences, in view of the great influence of her translation and production (see 3.3). Hence, dialectically, her self-censorship through localising the lesbian monologue can be regarded as 'productive' censorship, an example of the 'creative' as opposed to 'repressive' power of censorship (see Baer 2011: 22)

$\mathrm{Ai}$ Xiaoming is a well-known feminist activist in China. Her self-censorship reveals the power of the traditional view of (homo)sexuality. China has had a long tradition of treating sex as something obscene, as a corruption, as something that can be done secretly but cannot be talked about openly. It reached an extreme during the Cultural Revolution, which has had a profound influence among Chinese people even today. Li Yinhe has expressed surprise at the banning in 2004 of the first commercial Chinese production in Shanghai and of the informal, non-profit English production for raising money in Beijing. She 
contends that this production should not be banned in China, a socialist country under the leadership of the Communist Party with equality between men and women as a basic state policy, because what this play seeks is exactly equality between men and women. She construes the banning as an anti-sex attitude since the title of the play is startling with the word 'vagina' in it. She asserts that the banning proves that the views on sex of many Chinese people still remain at the level of 1,000 years ago (Kahn 2004, Li Yinhe 2006b, Cao Shuying 2007). Ai Xiaoming expressed her anger at hearing about the banning of the productions in other cities and questioned: "What is wrong with "vagina"? Why can't it be spoken? Why trample on vagina?' She condemned the banning as restricting women's expression (see Jiang Hua and Dong Jun 2004). ${ }^{6}$

This anti-sex attitude erupted again when the public production toured to Shenzhen in March 2010 after its success in Beijing and Shanghai. This time the resistance was not from the authorities but from the public. A production is usually approved if it is not pornographic and/or politically sensitive. However, the title upset the local people, which led to a series of consequences. The production leaflets were not allowed to be distributed in many public places. Advertisements in taxis and video advertisements in buses were rejected. Outdoor light-box advertisements had to be removed due to complaints. Every theatre refused the poster, including the Children's Hall, the venue of the production. What was even worse, Children's Hall later refused to provide the venue after receiving complaints. Most of the media thought that this production should not be reported (Huang Lu 2010).

All the rejections originated just from the sensitive word 'vagina'. Ironically, the resistance came mostly from those who did not know the play. Ignorance led to prejudice. The resistance from the public, together with the banning from the authorities, made the production 'the most controversial play in history', and the controversy in turn became a good advertisement for the production (Shi Xiaoyan 2010). The production in Shenzhen was finally provided a venue by the Shenzhen Women and Children Theatre, and turned out to be very popular, earning lots of good comments from the audiences. Subsequently, the production had its second tour to Shenzhen three months later (Huang Lu 2010, Shi Xiaoyan 2010). The resistance from the public in Shenzhen proves Li Yinhe's comments on the backward view of many Chinese people towards sex (Li Yinhe 2006b).

According to Ensler, the play had been staged in 1,100 cities around the world by 2004 and censorship had been rare, even in deeply religious countries, except in some Catholic colleges in the United States (Kahn 2004). The censorship and resistance the play has encountered in China seem unusual since most of the stories in the play are inoffensive in the Chinese context and sexual content is not rare in literary works of the same time or even before it in China. According to Yu Rongjun, the rationale for Ensler in writing monologues about the female sexual organ rather than monologues of other organs is the cause of such resistance. He points out that the female physical organ 'vagina' has been closely related to the obscene and the private. As a result, the vagina and its 
related pubic hair have become taboo in public speech, except to physicians. Consequently, female bodies have been ignored and forgotten. Vaginas and pubic hair have become taboo because they are connected with female sexual desire, which a patriarchal culture must suppress in order to consolidate its dominance. That is why Yu Rongjun thinks it significant to translate TVM and put the work on the stage (Duanmu Zhengyang 2004). Yu's interpretation exposes the shackles on the female body and female sexuality by a patriarchal culture.

The most important reason for the resistance from the authorities and the public may be that TVM not only discusses sex and violence, but pays much attention to female sexual pleasure, especially female auto-erotic activity and female homo-erotic desire. This contradicts the traditional patriarchal belief that women's sexual pleasure is given by men and must be gained through sex with men. Women enjoy no autonomy in orgasm. 'The Vagina Workshop' helps women learn to gain clitoral orgasm, subverting patriarchal myths in sex and 'an implicit hierarchy of sex' (Duanmu Zhengyang 2004, Sang 2002: 524). Autonomous female sexuality threatens the social sex norms and 'the model of sexual and marital harmony upheld by the dominant discourse' (Evans quoted in Sang 2002: 527), upsets social 'moralistic expectations' that 'presume the obscenity of homoerotic desire', and implies 'a reversal of power relationship' (Sang 2002: 526/539). Even the heterosexual stories in the play are mostly intended to expose violence in heterosexuality. Such a play can hardly find a good place in a patriarchal society. This largely explains why none of the Mainland translations have been published in book form, because 'what kind of sex act [i]s described and by whom' makes a great deal of difference for censors (Sang 2002: 524).

Another important reason for the institutional censorship may be that the play touches an often-ignored social problem-women's sexually inferior position in society. Its publication in book form would mean wider circulation, and inevitably increase an awareness of the social problems and dissatisfaction with the reality of women's status. Ai Xiaoming became aware of women's real position in China during her academic visit to America where she was surprised to see so many books on women/gender/queer studies. This led to her active involvement in feminist activities (Jiang Hua and Dong Jun 2004). In this sense, greater awareness of women's position by more people may lead to greater activism, potentially 'threatening' the social stability, which is of the utmost importance to the authorities.

Other reasons, such as economic considerations, are also important. Although with the establishment of a socialist market economic system in the mid-1990s, publication of translations has become more open and even two uncensored Chinese translations of Ulysses were published (Li Jingrui 2008b), imported books since the late 1990s have become market-oriented, shifting towards 'practical types' and 'fast-food types', such as economics and administration books, books for encouragement and self-improvement, and books for children. As a result, books of taste and value, such as academic and intellectual books, have lost their attraction to publishers (Anonymous 2008). Sex books or books 
containing much sex published so far are mainly of two types: classics and pornographic works. Both are profit-making. TVM is a more recent feminist work, which has its political importance but may not be that profitable because sexual descriptions in pornographic works (and classics as well) usually mean to cater to the desires of men and tend to make much profit in this patriarchal society. In this respect, TVM appears out of step with Chinese society and therefore has been less attractive to publishers and even banned.

\subsection{Summary}

TSS and TVM both cite many stories of women's sexual experiences, happy and unhappy, but they have had different experiences of censorship. Censorship exercised in the Chinese translations of TSS and TVM reflects the reception of TSS and TVM in China, which is closely related to the social, historical, and political context.

TSS arrived in China in the 1980s when China had just opened its doors and sex was still a sensitive topic. However, TSS has encountered little censorship and has been well received by the authorities, intellectuals and the general public. TVM came to China at the beginning of the twenty-first century when 'sex norms' had 'eased considerably' (Kahn 2004). Nevertheless, the translations and productions have experienced several layers of censorship: self-censorship by the translators concerning lesbian sexuality; de facto rejection by the publisher (neither translations have been published in book form and are available only on the internet); the banning of productions by the authorities (such as in 2004), and resistance by the public to the production (such as the production in Shenzhen in March 2010). In addition to the social, historical, political, ideological and economic factors discussed above, the prestige of the authors, the cultural status of the texts, the types and genres of the texts, the forms of circulation, and the after-effects of the texts in China all play important roles.

Normally, censorship of sexual content operates more in literary works than in scientific texts. TSS is an academic work on the formation of women. The growth and change of the female body, and the formation, performance, and experience of female sexuality are an important part of the work as they go through a woman's life. With these cut out, the work would not be comprehensible. Beauvoir analyses the female body and sexuality in the life experience of various women from youth to old age in order to reveal how women become the second sex in patriarchal societies. The sexual content is not for arousing sensual pleasure among its readers but for arousing women's (and men's) awareness of women's oppression and for moving towards women's liberation from patriarchal subjugation. In other words, it is educational, not titillating. TSS did arouse much controversy in France when published in 1949, but the content was no longer that sensitive 30 years later when the Chinese translations came out, not to mention that the English source text had already undergone censorship. Although there have always been readers taking TSS as a book about sex both in China and in the West (see Patterson 1992: 42, Fallaize 1998: 8, Wang 
Yi 2001), they are a minority among its readers. It has been categorised as a sociological work by the publishers and studied from different perspectives, especially philosophy and gender/women's studies in China. As a feminist classic, TSS fitted in with the social appeal for a renewed gender relationship when it arrived at China. This, together with Beauvoir's influence in China, determines its smooth circulation in China.

TVM is a much more physical text and has only received a marginal place so far. It came to China at a time when social stability was of the utmost importance to the authorities. Unfortunately, TVM is meant to be provocative. It was published in the late 1990s and its content is closer to present life. The localised stories in Ai's translation not only expose women's problems in history, but also break the illusion that Chinese women enjoy equality with men. Thus, it poses a potential threat to the seeming gender balance, and sexual and marital harmony in present China. As a result, TVM has experienced many more obstructions in its circulation in China.

On the whole, the circulation of TSS and TVM is limited, with their audiences mainly consisting of intellectuals and from urban areas, due to the vastness of China and the wide gap, conceptually and intellectually, between people in the rural and urban areas of the country. On an intellectual or philosophical level, the authorities and the people have been willing to grant women (near) equal status, therefore TSS has gained greater acceptance. On a physical or visceral level, however, the authorities and the people are less willing to think about or debate women's bodies, especially the vagina; hence TVM has encountered both institutional and personal censorship, with much resistance, modification, and adaptation.

\section{Notes}

1 Chang Nam Fung does not provide the Chinese characters of the TT in Examples 1 and 2, which should be: “你的性欲真的非常强吗?’ and “你没有暴虐过你的妻子吗?’ respectively.

2 The term 'yellow cover books', a special product at a special time, refers to those Western literary books selected to be translated and published for internal reference and criticism in the 1960s and 1970s. These books all had yellow covers and were called yellow cover books. Only about 900 copies of each book were printed, and were targeted to senior officials and famous writers, and not meant for public distribution. For more details, see Liang Zimin and Bi Wenchang 2006, Zhang Fusheng 2006, and Wang Qiaoling 2008.

350,000 words of descriptions of sexual love had to be deleted from 情爱论 [On Love] in order to get it published (Shen Changwen in Zhang Qing and Hu Hongxia 2009).

4 Perhaps because they are banned books, the English titles for 玫瑰梦 [Rose Dream] and 暴力与色欲 [Violence and Lust] are hard to find. The titles given in square brackets are my back-translations into English.

5 The story behind the banning was absurd (see Chen Xiaoping 2008; also see 7.1), and only about six months later, the publishing house was allowed to sell the blocked books, due to a strong call for unbanning by readers (Liu Shengquan 2009: 27). Lady Chatterley's Lover was banned again when it was published in 2004 by the People's Literature Publishing House, because somebody in a position of power said that the 
publishing house published without authorisation a book banned in the 1980s (Hei Ma 2008).

6 The original words are: 阴道怎么了? 为什么不能说? 为什么要践踏阴道? 我觉得他是 在限制妇女的表达。

\section{Bibliography}

Ai，Xiaoming 艾小明 (trans.) (2003a) 阴道独白 [The Vagina Monologues], http:// smileinwind.bokee.com/2440712.html (last accessed on 31 March 2006).

Anonymous (2005) '海关总署关于转发国内查禁的书刊目录的通知' [Announcement of the General Administration of Customs Concerning Transmitting the List of Banned Books and Periodicals in China], www.chinesetax.com.cn/haiguanshiwu/haiguanzhengce/ 200502/34533.html (last accessed on 16 February 2010).

- (2008) '中国改革开放30年引进版畅销书甄析一一兼观三十年外来文化引进与中国 人心灵成长历程' [The Examination of Translated Bestsellers in Three Decades of Reform and Opening Up in China: How Did Western Culture and Translated Bestsellers Change Chinese People's Thoughts], 中国图书商报 [China Book Business Report], www.cbbr.com.cn/infol85061.htm (last accessed on 15 February 2010).

- (2010) '形形色色的《洛丽塔》中译本' [Various Chinese Translations of Lolita], www.hi-av.com/g/view/id- 36801 (last accessed on 14 March 2010).

Baer, Brian James (2011) 'Translating Queer Texts in Soviet Russia', Translation Studies 4(1): 21-40.

Billiani, Francesca (2009) 'Censorship', in Mona Baker and Gabriela Saldanha (eds) Routledge Encyclopedia of Translation Studies (2nd edition), London: Routledge, 28-31.

Burger, Richard (2012) Behind the Red Door: Sex in China, Hong Kong: Earnshaw Books. Cao, Shuying 曹疏影 (2007) “阴道的复数“独白”——记《阴道独白》在中国” [Plural 'Monologue' of Vagina: The Vagina Monologues in China], http://genders.zsu.edu.cn/ News/1768-Content-1768.html (last accessed on 7 June 2010).

Chan, Red (2007) 'One Nation, Two Translations: China's Censorship of Hillary Clinton's Memoir', in Myriam Salama-Carr (ed.) Translating and Interpreting Conflict, Amsterdam and NewYork: Rodopi, 119-131.

Chang, Nam Fung (2008) 'Censorship in Translation and Translation Studies in Present-day China', in Teresa Seruya and Maria Lin Moniz (eds) Translation and Censorship in Different Times and Landscapes, Newcastle: Cambridge Scholars Publishing, 229-240.

Chen, Cangduo 陈苍多 (trans.) (2000) 阴道独语 [The Vagina Monologues], Taibei: 新雨 出版社 [Xinyu Publishing House].

Chen, Huan 陈欢 (2004) ““正本清源”女性“圣经”, [Tracing the Women’s Bible Back to its Origin], 中华读书报 [China Reading Weekly], 4 August 2004, www.gmw. cn/01ds/2004-08/04/content71928.htm [last accessed on 16 May 2009].

Chen, Xiaoping 陈晓萍 (2008) “一部禁书的中国遭遇' [The Banning and Unbanning of a Book in China], 中国新闻周刊 [China New Week] 4, http://gaige.rednet.cn/c/ 2008/03/22/1467308. htm (last accessed on 12 March 2010).

Cheng, Hongwu 成红舞 (2013) “《第二性》在中国大陆的译介一一基于性别研究视角的 考察' [Translation and Introduction of The Second Sex in Mainland China-Investigating from the View of Gender Theory], 济南大学学报（社科版） [Journal of University of Jinan (Social Science Edition)] 23(5): 31-36, 91.

Chou, Wah-Shan (2001) 'Homosexuality and the Cultural Politics of Tongzhi in Chinese Societies', in Gerard Sullivan and Peter A. Jackson (eds) Gay and Lesbian Asia: Culture, Identity, Community, New York, London, Oxford: Harrington Park Press, 27-64. 
Cui, Zi'en 崔子恩 (dir. and producer) (2008) 同志 [Queer China, 'Comrade' China], DVD, documentary film, Beijing: Beisen Culture and Li Xianting's Film Fund.

Dai, Jinghua 戴锦华 (1999) 犹在镜中 [As if in the Mirror], Beijing: Knowledge Press.

- (2007) ‘岁月留痕' [Time Leaves Traces], 书屋 [Book Room] 10: 36-41.

Dai, Shuang 戴爽 (ed.) (2008) ‘中国谈性色变已成往事' [Chinese People Turning Pale at the Mention of Sex is a Thing of the Past], 京华时报 [Beijing Times], http://gb. cri.cn/18824/2008/12/12/3365s2359024.htm (last accessed on 12 March 2010).

Drury, Russell (1998) 'Publishing in China: Developments Since 1992', Asia Libraries 7(5): 111-119.

Duanmu, Zhengyang 端木正阳 (2004) ‘女性的秘密花园会说话’ [Woman’s Secret Garden Can Speak], http://qkzz.net/article/3aaf3f9b-2039-4547-aee6-a7353d7e8a57.htm (last accessed on 7 June 2010).

Fallaize, Elizabeth (ed.) (1998) Simone de Beauvoir: A Critical Reader, London and New York: Routledge.

Flotow, Luise von (1997) Translation and Gender: Translating in the 'Era of Feminism', Manchester: St Jerome.

Forster, Penny and Imogen Sutton (eds) (1989) Daughters of de Beauvoir, London: The Women's Press.

Han, Ziman 韩子满 (2008) ‘翻译与性禁忌——以 The Color Purple的汉译本为例' [Translation and Sex Taboo-A Case Study of the Two Chinese Translations of The Color Purple], 解放军外国语学院学报 [Journal of PLA University of Foreign Languages] 31(3): 80-86.

Hei, Ma 黑马 (2008) ‘朱正先生只回头但不看左右’ [Mr Zhu Zheng Looked Back But Did Not Look Left or Right], www.360doc.com/content/08/0628/08/19446_ 1377273.shtml (last accessed on 12 March 2010).

Ho, Loretta Wing Wah (2008) 'Speaking of Same-Sex Subjects in China', Asian Studies Review 32(4): 491-509.

Huang, Lin 荒林 (2006) '作为女性主义符号的另类场景' [Another Context of Feminist Symbols], 中国图书评论 [China Book Review] 5: 78-84.

Huang, Lin 荒林 and Zhuge Wenrao 诸葛文饶 (2007) ‘西方女性主义理论在中国的传 播和影响' [The Propagation and Impact of Western Feminist Theories in China], 海南师范大学学报 (社科版) [Journal of Hainan Normal University (Social Sciences)] 20 (2): 76-91.

Huang, Lu 黄璐 (2010) “《阴道独白》惹火了深圳的谁? [Whom has The Vagina Monologues Annoyed?]’, 南方都市报 [Southern Metropolis Daily], 13 March 2010, www.artc.net. $\mathrm{cn} /$ peripheral/shownews.asp?id=416 (last accessed on 7 June 2010).

Jeffreys, Elaine (ed.) (2006) Sex and Sexuality in China, London and New York: Routledge.

Jiang, Hua 江华 and Dong Jun 董珺 (2004) ‘艾小明: 我大概勉强可以归为女人’ [Ai Xiaoming: I May Be Catagorised as a Woman with Bad Grace], 人物周刊 [VIP Weekly] www.nanfangdaily.com.cn/nfrwzk/20041103/gg/200411220019.asp (last accessed on 4 July 2008).

Kahn, Joseph (2004) 'Beijing Journal: Offended by the V-Word, China Mutes "Monologues"', New York Times, 13 February 2010, Section A, Column 3, p.4, www.nytimes. com/2004/02/13/international/asia/13CHIN.html (last accessed on 2 June 2010).

Kuhiwczak, Piotr (2014) 'Translation and Censorship' (in Translation Studies Forum: Translation and Censorship), Translation Studies 4(3): 358-373.

Leung, Helen Hok-Sze (2002) 'Thoughts on Lesbian Genders in Contemporary Chinese Cultures', Journal of Lesbian Studies 6(2): 123-133. 
Li, Jingrui 李景端 (2008a) ‘引进版图书现状浅析 [The Status Quo of Imported Books]’, 中华读书报 [China Reading Weekly], 18 January 2008, www.cbi.gov.cn/wisework/ content/14067.html (last accessed on 16 March 2010).

- (2008b) ‘中国翻译出版风雨三十年' [The Ups and Downs of Publishing Translated Works in the Past Three Decades], www.china.com.cn (last accessed on 15 February 2010).

Li, Qiang 李强 (trans.) (2004) 第二性 [The Second Sex], Beijing: 西苑出版社 [Xiyuan Publishing House].

Li, Xiaojiang 李小江 (1999) ‘世纪末看“第二性”, [Looking at 'the Second Sex' at the End of the Century], 读书 [Reading Books] 12: 98-103.

- (2006) 女人: 跨文化对话 [Women: Cross-Cultural Dialogue], Nanjing: Jiangsu People's Publishing House.

Li, Yinhe (2006a) 'Regulating Male Same-Sex Relationships in the People's Republic of China', in Elaine Jeffreys (ed.) Sex and Sexuality in China, London and New York: Routledge, 82-101.

- (2006b) “《阴道独白》在中国的遭遇” [The Banning of The Vagina Monologues in China], http://news.xinhuanet.com/forum/2006-09/07/content5057 140.htm (last accessed on 7 June 2010).

- (2008) '公众对同性恋的态度' [The Public's Attitude Towards Homosexuality], www.chinavalue.net/Article/Archive/2008/6/17/126619.html (last accessed on 26 May 2010).

Liang, Zimin 梁子民 and Bi Wenchang 毕文昌 (2006) ‘黄皮书的功能变迁' [Changes of the Function of Yellow Cover Books], 中国青年报冰点周刊 ['The Freezing Point', China Youth Daily], 6 September 2006, http://zqb.cyol.com/content/ 2006-09/06/ content1501646.htm (last accessed on 12 April 2010).

Liu, Shengquan 刘升铨 (2009) '对 《查太莱夫人的情人》的查处、解禁与反思' [The Banning, Unbanning and Rethinking of Lady Chatterley's Lover], 华人性文学艺术研 究 [Chinese Sexuality Literature \& Art Research] 4(3): 22-28.

Liu, Xiantao 刘先涛 (1999) ‘试论我国翻译图书事业的两起两落” [On the Two Ups and Downs in Translation Publication in China], 内蒙古师大学报 (哲学社会科学版) [Journal of Inner Mongolia Normal University (Philosophy and Social Science)] 28(1): 103-107.

Lung, Rachel (2003) 'Translating Sensitive Texts', Perspectives: Studies in Translatology 11(4): 240-253.

Luo, Ting 罗婷 and Wang Fang 王芳 (2004) ‘波伏娃在中国的接受与影响’ [The Reception and Influence of Simone de Beauvoir in China], 当代外国文学 [Contemporary Foreign Literature] 4: 123-129.

Mann, Susan L. (2011) Gender and Sexuality in Modern Chinese History, New York: Cambridge University Press.

McMillan, Joanna (2006) Sex, Science and Morality in China, London and New York: Routledge.

Moi, Toril (2002) 'While We Wait: The English Translation of The Second Sex', Signs 27(4): 1005-1035.

Nord, Christian (1995) 'Text-functions in Translation: Titles and Headlines as a Case in Point', Target 7(2): 261-284.

Pan, Suiming (2006) 'Transformations in the Primary Life Cycle: The Origins and Nature of China's Sexual Revolution', in Elaine Jeffreys (ed.) Sex and Sexuality in China, London and New York: Routledge, 21-42.

Patterson, Yolanda Astarita (1992) 'Who was This H. M. Parshley?: The Saga of Translating Simone de Beauvoir's The Second Sex', Simone de Beauvoir Studies 9: 41-47. 
Qin, Julia Ya (2011) 'Pushing the Limits of Global Governance: Trading Rights, Censorship and WTO Jurisprudence-A Commentary on the China-Publications Case', Chinese Journal of International Law 10(2): 271-322.

Sang, Tze-Ian D. (2002) 'At the Juncture of Censure and Mass Voyeurism: Narratives of Female Homoerotic Desire in Post-Mao China', GLQ: A Journal of Lesbian and Gay Studies 8(4): 523-552.

_ (2003) The Emerging Lesbian: Female Same-Sex Desire in Modern China, Chicago and London: The University of Chicago Press.

Sang, Zhuying 桑竹影 and Nan Shan 南珊 (trans.) (1986) 第二性一一人 [ The Second Sex一Women], Changsha: 湖南文艺出版社 [Hunan Literature \& Art Publishing House].

Santaemilia, José (2008) 'The Translation of Sex-related Language: The Danger(s) of Self-censorship(s)', TTR 21(2): 221-252.

Shenzhen, Fanyi (2009a) ‘怎么能这样翻译? 述出版社翻译这乱套事 [How Can It Be Translated in This Way? The Muddle of Translation by the Publishing House]', www. transtounion.com/newsview.asp?id=239 (last accessed on 12 March 2010).

— (2009b) “深圳翻译再看《红字》翻译 三译本对比 [Shenzhen Translation Look at the Translation of The Scarlet Letter Again: A Comparison of its Three Translations]', www.transtounion.com/newsview.asp?id=240 (last accessed on 12 March 2010).

Shi, Xiaoyan 史小岩 (2010) ‘说说女人的那些事《阴道独白》6月再来深 [Talking About Women's Things, The Vagina Monologues Will Come Again to Shenzhen in June]', 深圳晚报 [Shenzhen Evening Post] B8, 27 May 2010, http://wb.sznews.com/html/ 2010-05/27/content1089621.htm (last accessed on 7 June 2010).

Shu, Xiaofei 舒小菲 (trans.) (2009) 第二性 [The Second Sex], Beijing: 西苑出版社 [Xiyuan Publishing House].

Sigley, Gary (2006) 'Sex, Politics and the Policing of Virtue in the People's Republic of China', in Elaine Jeffreys (ed.) Sex and Sexuality in China, London and New York: Routledge, 43-61.

Simons, Margaret A. (1983) 'The Silencing of Simone de Beauvoir: Guess What's Missing from The Second Sex', Women's Studies International Forum 6(5): 559-564.

Tang, Yi 唐译 (trans.) (2009) 第二性女人 [The Second Sex Woman], Beijing: 北京燕山 出版社 [Beijing Yanshan Press].

Tao, Tiezhu 陶铁柱 (trans.) (1998) 第二性（全译本) [The Second Sex (complete translation)], Beijing: 中国书籍出版社 [China Books Publishing House].

Thurman, Judith (2009/2010) 'Introduction', in Simone de Beauvoir The Second Sex, translated by Constance Borde and Sheila Malovany-Chevallier, New York: Knopf, ix-xvi.

Tian, Zhiling 田志凌 and Zhang Hao 张昊 (2008) “汉译名著让中国经历新的“思想启蒙” ’ [Chinese Translations of Masterpieces Led to China's New Experience of 'Thought Enlightenment'], 南方都市报 [Southern Metropolitan Daily], http://nf.nfdaily.cn/ nanfangdaily/zt/jnggkf/whsj/200811120067.asp (last accessed on 15 February 2010).

Wang, Qiaoling 王巧玲 (2008) ‘黄皮书、灰皮书: 一代人的精神食量' [Yellow Cover Books, Gray Cover Books: Spiritual Food for a Generation], 新世纪周刊 [News Magazine], 11 July 2008, http://book.ifeng.com/special/30reading/list/200807/ 071148318405203.shtml (last accessed on 12 April 2010).

Wang, Yi (2001) ‘读书笔记: “性书”盘点 [Reading Notes: An Inventory of 'Sex Books']', http://home.donews.com/donews/article/1/17549.html (last accessed on 15 February 2010).

Wang, Youqin 王友琴 and Qiu Xichun 邱希淳 et al. (trans.) (1988) 女人是什么 [ What is Woman], Beijing: 中国文联出版公司 [China Federation of Literary and Art Circles Publishing Corporation]. 
Wang, Zheng (1993) 'Three Interviews: Wang Anyi, Zhu Lin, Dai Qing', in Tani E. Barlow (ed.), Gender Politics in Modern China, Durham, NC: Duke University Press. 159-208.

Wang, Zhisong 王志松 (2010) ‘90年代出版业的市场化与“情色描写”一一与日本翻译文 学的关系' [The Marketisation of the Publishing Industry in the 1990s and 'Erotic Description': Related to Japanese Translated Literature], 日语学习与研究 [Japanese Learning and Research] 4: 11-18/63.

Wu, Xusheng 伍旭升 (chief ed.) (2009) 30年中国畅销书史 [Bestselling Books of the Past 30 rears in China], Beijing: 中国对外翻译出版公司 [China Translation and Publishing Corporation], http://vip.book.sina.com.cn/book/catalog.php?book=105347 (last accessed on 8 November 2011).

Xiao, Yi 晓宜 and Zhang Yali 张亚莉, et al. (trans.) (1988) 女性的秘密 [Female Secrets], Beijing: 中国国际广播出版社 [China International Radio Press].

Xie, Tianzhen 谢天振 (2009) ‘非常时期的非常翻译——关于中国大陆文革时期的文学翻 译' [Particular Translations During Particular Periods: On Literary Translation in the Mainland During the Cultural Revolution], 中国比较文学 [Comparative Literature in China] 2: 23-35.

Yu, Rongjun 喻荣军 (trans.) (2003) 阴道独白 [The Vagina Monologues], http://bbs. sachina.pku.edu.cn/archiver/tid-3681.html (last accessed on 27 December 2006).

Zhang, Fusheng 张福生 (2006) ‘我了解的“黄皮书”出版始末' [What I Know About the Publication of 'Yellow Cover Books'], 中华读书报 [China Reading Weekly], 23 August 2006, www.china.com.cn/international/txt/2006-09/08/content7142791. htm (last accessed on 12 April 2010).

Zhang, Longxi (1998) Mighty Opposites: From Dichotomies to Differences in the Comparative Study of China, Stanford: Stanford University Press.

Zhang, Qi 张祺 and Pang Minghui 庞明慧 (2003) ‘重新想象女性的身体: 《阴道独白》 广州演出综述' [Re-imaging the Female Body: A Review of the Performance of The Vagina Monologues in Guangzhou], http://cyc6.cycnet.com:8090/othermis/stopdv/ content.jsp?id=8812 (last accessed on 6 July 2008).

Zhang, Qing 张清 and Hu Hongxia 胡洪侠 (2009) 1978-2008 私人阅读史 [1978-2008 Individual Reading Experiences], Shenzhan: 深圳报业集团出版社 [Publishing House of Shenzhen Press Group].

Zhang, Wenxian (1990) 'Fire and Blood: Censorship of Books in China', International Library Review 22(1): 61-72.

Zhang, Yin 张英 and Huang Min 黄敏 (2006) ‘50岁《洛丽塔》11张中国脸禁书成世 纪经典' [50-year-old Lolita: Eleven Chinese Faces, Banned Book Has Become a Century Classic], 南方周末 [Southern Weekend], 16 March 2006, http://book.sina.com.cn (last accessed on 14 March 2010).

Zheng, Kelu 郑克鲁 (2011)《第二性》[The Second Sex], Shanghai: 上海译文出版社 [Shanghai Translation Publishing House].

Zheng, Shuhua 郑淑华 and Tian Liping 田利平 (2001) ‘我国重新定义精神病标准 同性 恋不再统划为病态' [China Redefines Psychosis, Homosexuality is No Longer Categorised as a Disease], 北京青年报 [Beijing Youth Daily], 12 March 2001, www.blog. china.com.cn/herihui/art/3277557.html (last accessed on 26 May 2010). 


\section{Conclusion}

\section{Gender, feminism, and translation studies}

In previous chapters, I reviewed the major Canadian feminist translation strategies and discussed the nature of the so-called feminist translation strategies. These are followed by a review of feminist translation studies within and outside China to locate where we are in feminist translation studies. Then I made a thorough study of the Chinese translations of the two feminist works The Second Sex (TSS) and The Vagina Monologues (TVM), investigating when, why, and how the translations were produced, and by whom, focusing on how the materials of the female body and female sexuality were rendered. Through the analysis, I have identified strategies used in the Chinese translations of TSS and TVM, and discussed the effects of the strategies from a feminist perspective. I also identified from the analysis censorship of sexuality, especially censorship of lesbianism, which intimates a particular kind of reception in the specific social, historical, political and economic context. The ups and downs of the translation publishing industry in China largely account for the fate of each translation. In this chapter, I am looking into the overall effects of the translation strategies, the implications of censorship of lesbianism for the reception of Western feminism in China and for the development of Chinese feminism, the issue of essentialism in (feminist) translation studies, and the prospects of feminist translation studies.

\subsection{Gender, translation strategies, and translation effects}

The analysis of the translation strategies in dealing with the materials of the female body, female sexuality, and lesbianism in TSS and TVM discloses similarities and differences between the translations at different levels and in different aspects, which carry different implications. Although TSS and TVM are two different types of texts and were translated at different times, the analysis shows similarities between the translations by the female translators and between those by the male translators. In their translations of TSS and TVM, the female translators on the whole respond similarly and so do the male translators. The women translators mainly keep close to the source texts, and their translations frequently reveal sympathy towards women and lesbianism, feminist awareness, and the feminist stance. Their translations in some cases also show that the female translators are more conservative in translating the female body and female sexuality, 
and more constrained by patriarchal culture. Feminist interventions, mild or radical, appear in the women's translations. Although sympathy towards women, feminist awareness, and the feminist stance sometimes also appear in the men's translations, quite a number of problems occur, such as the male perspective (male gaze, male judgement or a patriarchal view of the female body and female sexuality), negative attitudes towards lesbianism, meaningless translation, and mistranslation. The male translators seem to be detached in some cases when translating the female body, female sexuality, and lesbianism, and hence, the feminist message is either lost or reduced. The fluctuations in the men's translations prove that the intervention by the translator is 'rarely so black and white' (Munday 2008: 221). Several strategies are found exclusively in the men's translations: literal translation, bilingual translation, zero translation, and transliteration. This means the male translators keep the exotic elements of the source texts in the target texts, while the female translators either convey the (contextual) meaning of the exotic elements, such as the foreign terms in TSS, or simply remove the exotic elements that are considered unimportant or irrelevant to Chinese readers, such as the American vagina terms in TVM.

One difference between the Chinese translations of TSS and TVM is that more strategies are used in the translations of TVM: twelve are used in the translations of TVM while there are eight in those of TSS. This has much to do with text types and translation purposes. TSS is a feminist classic, and the translators were less constrained in translating the text. TVM is a provocative feminist play and a text open to update. As mentioned in 3.3, Ensler permits new stories to be incorporated into TVM when necessary, such as to embody the annual theme of the V-Day movement. Although there are restrictions on additions and alterations for a TVM performance according to V-Day's guidelines (Cheng 2004: 327, Cooper 2007: 729), in view of the American base of TVM, adaptations are inevitable to suit the indigenous culture and audience. Adaptation has been identified in both Yu Rongjun's and Ai Xiaoming's translations. Broadly speaking, adaptation involves rewriting a foreign text for its target readership, making the text suit the tastes and habits of the target culture while maintaining some form of equivalence between the source and target texts. As a cultural translation strategy, it is predominantly applied in drama translation (among others) to 'naturalise' the play for a new milieu and achieve the same effect as the source text (Bastin 2009: 3-4). The main concern is 'relevance' rather than 'accuracy'. It seeks to transmit the 'purpose' of the source text. Adaptation has been regarded as a kind of censorship by many historians and scholars of translation (Bastin 2009:3-6). Adaptation is often seen as the translator's selfcensorship, 'an individual ethical struggle between self and context' (Santaemilia 2008: 221-222). That somewhat explains why mild feminist strategies are used in the translations of TSS, while more radical feminist interventions are seen in the translations of TVM. The discussion of Canadian feminist translation strategies in Chapter Two and the analysis of the strategies identified in the translations of TSS and TVM show that strategies per se cannot be labelled feminist or unfeminist (my term). It is the use, the purpose, and the effect that 
define whether a strategy is feminist or not. The feminist interventions found in the translations of TSS and TVM, mild or radical, are different in form from but similar in spirit to the Canadian feminist translation strategies.

Censorship or self-censorship happens in the Chinese translations in question of both TSS and TVM, except in the translation by $S / \mathrm{N}$. The analysis has clearly shown that censorship concerning sexuality occurs exclusively in the Mainland translations of TSS and TVM. 'The Lesbian' and 'Prostitutes and Hetairas' are cut in W/Q's translation of TSS. It is not clear whether the cutting in W/Q's version is a decision by the translators or the editor(s). As for TVM, Ai Xiaoming dramatically condenses the story of the lesbian prostitute, deletes the follow-up interview which contains graphic description of lesbian sex, and adapts the lesbian moaning theme into a Chinese heterosexual moaning story. The adapted moaning story moves away from the source culture but recreates the humour of the source text. Yu Rongjun also cuts the erotic description of lesbian sex to make his translation more suitable for the stage. The fact that censorship of sexuality does not happen to the two Taiwan translations, i.e. the Chinese translation of TSS by S/N (1986) and the Chinese translation of TVM by Chen Cangduo (2000), reflects a more permissive social environment concerning (homo)sexuality in Taiwan. Of course, Chen's interest in erotic literature and his translation not being meant for the stage also contribute to the lack of censorship in his translation of TVM (see 3.4).

Compared with the Chinese translations of TVM, the Chinese translations of TSS suffer less censorship. An important reason should be its text type. TSS is an academic book. In the reform era, the government is rather more tolerant of the discussion of sexual problems in academic works, and the 'production and practice of expert opinion about sex' are 'both economically profitable and politically desirable' (McMillan 2006: 1). More censorship in the translations of TVM reflects “性禁忌的力量” [the power of sex taboo] in literary translation, as well as the consideration of performability and reception of the production. Therefore, Mainland translators and publishers of translated works tend to dilute or delete sexual descriptions (Han Ziman 2008: 85). Compared with the Chinese translations of TSS and TVM by the female translators, the translations by the male translators of both works exhibit less censorship. Whether female translators tend to self-censor sexual materials more than male translators needs to be proved with more case studies.

The three censored translations of TSS and TVM came out at different times: 1988 (W/Q's translation) and 2003 (Yu Rongjun's and Ai Xiaoming's translations), covering a time span of 15 years. However, what has been censored is consistently related to lesbianism and prostitution. This is by no means a mere coincidence, but reflects an ingrained institutional and social rejection of homosexuality and prostitution in China. It shows that lesbianism is still 'dismissed as unnatural', even seen 'as a threat to social order' (Conboy et al. 1997: 5). The Chinese government has always identified gender, sex and family as a legitimate and necessary site of intervention', and has made great efforts to maintain the 'sexual order' (McMillan 2006: 129). The censorship of lesbianism 
in a way reveals a difference between Chinese feminism and Western feminism, representing a kind of clash of Western feminism with Chinese culture in the process of its dissemination in the Chinese context. Western feminism takes lesbianism as a weapon to fight against patriarchal sexual oppression, which is not the case in Chinese feminism. Therefore, in the very rich body of work on women and feminism in China, lesbian practices are barely mentioned (Leung 2002: 129). After all, the reception of Western feminism is a gradual process, as has been proved by the banning and resistance the productions of TVM have experienced in China. Persistent work of translators (i.e. translations and retranslations of feminist works) contributes to the gradual reception of feminism. In this sense, any translation strategies used in translating feminist texts to represent the feminism of the source texts can be regarded as feminist.

\subsection{Female/male: Essentialism?}

To some, a comparative study of translations by female and male translators will fall into the snare of essentialism, and it is even more so if the study reveals differences between translations by female and male translators. Since 2009, I have been presenting sections of this study at international conferences to seek feedback and observe responses from the audiences. Over the years, I have heard the charge of 'essentialist' on a few occasions. During a coffee break at a conference in Manchester in 2010, participants were asking what each other's presentation were about. As soon as they heard that my presentation would be a comparison of translations by translators of different gender identities, without knowing the real content, a participant immediately alleged: 'Essentialist! Essentialist!'. In the era of third-wave feminism, 'Do men and women translate differently?' has become a sensitive question. I have noted that scholars have been cautious and have tried to avoid falling into the snare by doing queer studies of translation, or by using 'yes, but ...' discourse in discussing the differences between translations by female and male translators they found in their studies.

Nevertheless, I have received more encouraging feedback on this study from scholars in gender studies and translation studies at difference occasions. In a conference in Oxford in 2010, scholars in gender studies showed great interest in the examples I presented of translating the female body in TVM and gave me valuable information in gender studies. At the 2013 Nida School of Translation Studies (NSTS) held in Italy, I presented some examples of translating the female body in The Second Sex. Dr Sue Yan Yu, a male associate of the 2013 NSTS, said to me: 'You selected very good examples. You are right! It is very difficult for men to translate the descriptions of the female body. We men can hardly grasp the delicate meaning, and can only guess when translating.' Sherry Simon, one of the two 2013 Nida professors, said to me: 'Your research is very interesting. Now I am convinced. [. . . ] I look forward to reading your book.' At the 2013 NSTS, I also discussed this research with the other 2013 Nida professor, G. C. Spivak. At the end of our talk, Spivak said that she looked forward to reading the finished product. 
What would translators say about the role of gender identity in translation? The case of Zheng Kelu, the male translator of the latest Chinese translation of TSS, gives us a good example. When giving a talk at a university about his Chinese translation of TSS from the French original, Zheng Kelu made the following remarks:

因为我是个男的, 对女孩子的心理状况不是很清楚。她讲的有些是不是事 实我不是很清楚, 也没办法判断。 [ . . . 她认为女孩子来月经是很重要的, 但是往往母亲就忽略了这个东西, 女孩子来月经之后很多都是惊慌失措, 如果处理不好就会神经混乱, 甚至是精神病。这点我也不是很清楚, 可能 中国不是这样吧, 我没见过这种情况, 是不是西方法国就是这样啊, 我不 清楚。

(Zheng Kelu 2010: 13)

[As a man, I am not clear about young girls' psychology. I am not clear whether what she (Beauvoir) says (in TSS) is true or not, and I have no way to judge. [...] She thinks menstruation is very important for girls, but mothers often neglect to inform them; many girls fall prey to panic by their first menses; if lacking wise instruction, they become anxious, or even mad. About these I am also not very clear. Maybe it is not so in China? I've never seen this. Perhaps in the West/France it is so? I don't know.] (my notes and my emphasis)

Zheng Kelu's remarks and Sue Yan Yu's comments to some extent explain why meaningless translation and mistranslation occur in the translations by the male translators of TSS and TVM and why the male translators opt for literal translation, a method often used when one is not very sure of the sense of the source text.

Is there any way to get rid of essentialism? According to Flotow, the male/ female binary (and its implied heteronormative stance) that had proven so productive for feminism was effectively shaken up and displaced by queer theories from the early to mid-1990s, which unfortunately has led to a notable decline in research relating to women and translation. Being aware that the queer approach is used to avoid definitions and categorisations, which causes a methodological problem, Flotow poignantly asks: What exactly do you study if you avoid definitions and categories? Can you do research on more than one individual if you cannot categorise or group people? She warns that the blurred boundaries or unfixed gender categories may be hampering development of (feminist) translation studies (Flotow 2012: 131-134).

Santaemilia also points out that the new social constructionism cannot prevent a more primary phenomenon. He contends that ' $[\mathrm{t}]$ hough we cannot always equate sex with gender, one feels a certain identification between him/herself and the rest of members of his/her sex'; and that ' $[\mathrm{t}]$ here are certain actions or topics that are likely to trigger a primary identification between the said action or topic and the translator as part of a sexual group/category', which has given 
rise to an important area of research as feminist translation (Santaemilia 2014: 109-110). He insists that since both men and women seem to move the texts they translate into their own ideological positions and any gender or sexual identity seems inseparable from any activity of (re)writing, such questions as 'Do men and women translate in the same way', 'Do female translators manipulate the text?', and 'What about male translators?' deserve a great deal of reflection, with the same standards, of course (Santaemilia 2011: 22).

Perhaps, at this stage, it would be more constructive to keep doing descriptive translation studies of what translators really do under various circumstances and how various factors, personal and social, affect translators' decision-making, than to judge or accuse a methodology as being essentialist. As pointed out in Chapter One, in this study it is the differences in the Chinese translations of TSS and TVM that have inspired me to look deeper into the differences between the translations by the female and male translators and investigate, in addition to other factors, whether and how much gender plays a role in the translation process, particularly in dealing with the materials of the female body and female sexuality. I was not motivated by the differences of the gender identities of the translators to exam how differently they translated. Thus, all the findings are confined to the specific cases, and there is no intention to generalise. Essentialist or not, we let the translation (or evidence) speak.

\subsection{Feminist translation studies: Where are we going?}

Chapter Two paints two pictures of feminist translation studies: a global one and a Chinese one. In the Chinese context, feminist translation studies is still an emerging branch in the large system of translation studies; whereas, with all the expansion and development, feminist translation studies seems to be at the crossroads on the world map. It is noted that while having become a mainstream term, 'gender' has also become contested in its academic usage and has not been very useful for broader questions in translation studies, and that queer theories do not seem to be promoting the development, because with the identity focus being switched to the 'other' genders, i.e. the GLBTs (gay, bi-sexual, lesbian, transsexual), women seem to have been moved out of the picture, or the focus on them has been obscured and dispersed by the foregrounding of the GLBT genders in many disciplines, such as sociology and literary studies (Rassier and Blume 2011:252, Flotow 2012: 134). In which case, what is the way out? Where are we going or where can we go in feminist translation studies?

Fortunately, solutions seem to have been suggested. Flotow calls for a return to 'women and translation' to 're-focus research work and interests on women writers, translators, characters, and their fates in translation' (Flotow 2011). Interestingly, there is also a call for attention to men and translation. Santaemilia reminds us that 'it would be a serious mistake to forget "men" (and "man") as part of the analysis', because 'at other times, men translators have also been ignored, censored or burned at the stake', and that the analytical category of 'men' (and 'man') can contribute to 'a fuller picture of the dialectics between 
men and women in and through translation, thus offering a key to the exclusion and subordination of women across literary, philosophical or translatological traditions'. He confirms that the sex of translation, i.e. translation by female and male translators, though easily prey to essentialism, is 'a productive area of research into the complexities of gender identity, and into questions of power and authority, of legitimation and intervention, of (self)censorship and ethics', and the translation of $\operatorname{sex}$ (uality) is an ideal site for testing the complex rewriting(s) of identity in sociohistorical terms, because 'the reference to love, sex and intimacy was powerful enough to provoke important translation effects' (Santaemilia 2014: 106, 110, also see Flotow 2000).

As for theoretical tools, while admitting that 'there could be a lot of room for "queering" translation' if queer theories 'allow categorization and some generalization which they often resist' (Rassier and Blume 2011:253), Flotow (2012: 136-138) seems to recommend a recent feminist psychoanalytic theory for translation, i.e. Bracha Ettinger's metramophosis, which theorises translation as a 'threshold' experience. It brings in the female/maternal element that has been exercised from conventional psychoanalytic thought, thinks beyond the domineering Phallus, and incorporates the feminine matrix. With this theory, 'the translational relation is seen as one of encounter, exchange, and mutual transformation rather than assimilation, displacement, or rejection', which 'promotes a view of translation as generative, as a labour that [ . . ] is dependent upon and in conversation with its environment, all the while exerting an influence on it as well'(Flotow 2012: 136-138). The two case studies in this book seem to have illuminated this.

The translations of TVM by Ai Xiaoming and Yu Rongjun, particularly the one by Ai Xiaoming (and many other campus productions in China), vividly illustrate the notion of translation as encounter, exchange, and mutual transformation, reflecting the mechanisms of translating Western feminism into the Chinese context. It is mentioned in Chapter Three (3.4) that Ai Xiaoming made a documentary ‘阴道独白: 幕后故事' [The Vagina Monologues: Stories Behind the Scenes]. This documentary was brought to America and played at the University of Illinois at Urbana-Champaign. The audiences were amazed by the influence of the American play in faraway China and expressed high appreciation of the Chinese translator's creative rewriting and localising to make the play more pertinent and closer to Chinese audiences. In contrast, campus productions in America seem more conservative and deficient. Two student performers of the University of Illinois at Urbana-Champaign criticised the increasingly institutionalised and bureaucratic V-Day movement, which stipulated that they must gain permission for their production and must promise not to make any changes to the original script, including adding any individualised and local elements. While showing respect for the copyright of the original script, this also led to the loss of the edge of criticism the play had had, the loss of the passion of creation from performers in a specific time and place, and the loss of the possible impact of local experiences. Professor Cris Mavo was surprised by and could not understand the stipulation that not a single word should be 
changed. Mavo expressed special appreciation of the translation and recreation of the play by the Chinese intellectuals, and thought that the Chinese version was well done, afforded lessons for American productions and was an important source for discussion by Gender Studies and China Studies students. The impact of the Chinese TVM in America represents a 'reverse flow of knowledge', showing that the third world does not always passively receive knowledge and experiences from the first world but also provides precious experiences for the first world feminist movement (Xiao Hui 2009: 66).

The influence or reception of TSS in China illustrates 'translation as generative', or how meaning is generated in the process of translating Western feminism into Chinese feminism. As discussed in Chapter Three, TSS came to China in the 1980s and started its influence on university female students and in academia, particularly in Chinese female literature and the development of feminist literary criticism. Actually, the influence of TSS has been spread through the aphorism 'one is not born, but rather becomes a woman' to a lot more people who have never read it. As Lydia Liu has pointed out, post-Mao Chinese women deal with 'an order of reality vastly different from that which feminists in the West face within their own patriarchal society, where the female gender is exploited more on the grounds of her difference than the lack thereof' (1991: 24). Beauvoir's aphorism has inspired Chinese women and women researchers to re-think the process of the formation of Chinese women and Chinese women's real situation (Chen Xiaoli 2009: 49-50). Huang Lin's remarks exhibit how the meaning of the aphorism is generated in the Chinese context:

而最为畅销的《第二性》, 以翻译语言的方式, 无疑参与了中国社会最激动 人心的性别变动与言说。“女人不是天生的, 而是变成的”一从英语译来的 这个汉语名句, 显明的意义所在是：女人的处境是可以改变的! 人们不关 心法语原句型，也不追问译成英语的句式是否符合波伏娃原意，这个充满 辩证思维的汉语句子，才是变动的中国的现实生活所需！ [...] 中国所期待 的女性主义符号, 是建设性和非破坏特点的。

(Huang Lin 2006: 80)

[And the biggest seller The Second Sex, in the form of translated language, without a doubt has been involved in the most exciting gender transformation and discourse in the Chinese society. 'Women are not born, but turned'-this famous Chinese sentence translated from English, discloses the important message that: Women's situation can be changed! People don't care about the French original syntax, nor question whether the translated English sentence conforms to Beauvoir's original meaning; this Chinese sentence which is full of dialectical thinking, is exactly what the reality of changing China needs! [...] The feminist symbol that China is expecting is of constructive and non-destructive nature.]

It can be expected that translations by translators of different gender identities and translation of feminist/women's writing will continue to be a productive 
research area, because much remains to be done, and because it is just gaining momentum in non-Euro-American countries like China. Take this study as an example. This research examines the strategies and their effects in translating the female body, female sexuality, and lesbianism, and the factors leading to censorship concerning sexuality in the Chinese translations of TSS and TVM. To be able to further justify these findings, more studies could be undertaken. More cases can be examined, not only translations of feminist texts from English into Chinese, but also translations from Chinese into English. As for the case of TSS, this study compares the Chinese translations from the English version. It is worthwhile to do a relay translation study, i.e. comparison between the Chinese, English and French versions, to investigate what has happened to the text during the process of travelling from the French source through English as mediator to the Chinese language. It would also be interesting to compare the Chinese translations from the English version with the Chinese translation from the French original to examine the translation effects of direct translation and indirect translation in transmitting feminism. Another good project could be comparing the Chinese translation from the French with the English translation from the French to compare the reception of feminism in different cultural contexts. As for the case of TVM, this study examined the three Chinese translations with some attention to the reception of its productions. It would be interesting to compare the productions in the Mainland, Hong Kong, Taiwan, and other Chinese communities around the world. It would also be interesting to investigate all the university (and school) productions in China. Commercial productions and campus productions in China also deserve a comparative study. The issue of censorship in Chapter Seven is discussed mainly within the social, historical and political context. The relationship between the translator's gender identity and (self-)censorship of sexual descriptions is also worth studying, which would entail plenty of case studies. Gender issues in translation are still new in (feminist) translation studies in China. Translating the female body and female sexuality is even fresher in (feminist) translation studies around the world. There is much to be explored in gender, sexuality, and censorship in translation. With the increase in research concerning nonEuro-American languages and cultures (as pointed out in Chapter Two) and the expansion of research areas, further development in feminist translation studies can be expected.

\section{Bibliography}

Ai, Xiaoming 艾小明 (trans.) (2003a) 阴道独白 [The Vagina Monologues], http://smileinwind. bokee.com/2440712.html (last accessed on 31 March 2006).

Bastin, Georges L. (2009) 'Adaptation', translated from Spanish by Mark Gregson, in Mona Baker and Gabriela Saldanha (eds) Routlege Encyclopedia of Translation Studies (2nd edition), London: Routledge, 3-6.

Chen, Cangduo 陈苍多 (trans.) (2000) 阴道独语 [The Vagina Monologues], Taibei: 新雨出版社 [Xinyu Publishing House]. 


\section{Conclusion}

Chen, Xiaoli 陈肖利 (2009) ‘波伏娃《第二性》对中国女性主义的启蒙’ [The Enlightenment from Beauvoir's The Second Sex to Chinese Feminism], Journal of China Women's University 6: 48-52.

Cheng, Sea Ling (2004) 'Vagina Dialogues?', International Feminist Journal of Politics 6(2): 326-334.

Conboy, Katie, Nadia Medina and Sarah Stanbury (eds) (1997) Writing on the Body: Female Embodiment and Feminist Theory, New York: Columbia University Press.

Cooper, Christine M. (2007) 'Worrying about Vaginas: Feminism and Eve Ensler's The Vagina Monologues', Signs 32(3): 727-758.

Flotow, Luise von (2000) 'Translation Effects: How Beauvoir Talks About Sex in English', in Melanie C. Hawthorne (ed.) Contingent Loves. Simone de Beauvoir and Sexuality, Richmond, VA: Virginia University Press, 13-33.

_ (ed.) (2011) Translating Women, Ottawa: University of Ottawa Press. - (2012) 'Translating Women: From Recent Histories and Re-translations to "Queerying” Translation, and Metramorphosis', Quaterns: Revista de traducció 19: 127-139.

Han, Ziman 韩子满 (2008) ‘翻译与性禁忌—— 以 The Color Purple的汉译本为例' [Translation and Sex Taboo-A Case Study of the Two Chinese Translations of The Color Purple], 解放军外国语学院学报 [Journal of PLA University of Foreign Languages] 31(3): 80-86.

Huang Lin 荒林 (2006) '作为女性主义符号的另类场景' [Another Context of Feminist Symbols], 中国图书评论 [China Book Review] 5: 78-84.

Leung, Helen Hok-Sze (2002) 'Thoughts on Lesbian Genders in Contemporary Chinese Cultures', Journal of Lesbian Studies 6(2): 123-133.

Li, Qiang 李强 (trans.) (2004) 第二性 [The Second Sex], Beijing: 西苑出版社 [Xiyuan Publishing House].

Liu, Lydia (1991) 'The Female Tradition in Modern Chinese Literature: Negotiating Feminisms Across East/West Boundaries', Genders 12: 22-44.

McMillan, Joanna (2006) Sex, Science and Morality in China, London and New York: Routledge.

Munday, Jeremy (2008) 'Translation Studies', Year's Work in Critical and Cultural Theory 16: 215-234.

Rassier, Luciana Wrege and Rosvitha Friesen Blume (2011) 'Entrevista com Luise Von Flotow', Cadernos de Tracdução 2(28): 251-273.

Sang, Zhuying 桑竹影 and Nan Shan 南珊 (trans.) (1986) 第二性一女人 [ The Second Sex一Women], Changsha: 湖南文艺出版社 [Hunan Literature \& Art Publishing House].

Santaemilia, José (2008) 'The Translation of Sex-related Language: The Danger(s) of Self-censorship(s)', TTR 21(2): 221-252.

_ (2011) 'Gender, Sex and Translation: Preface', in José Santaemilia and Luise von Flotow (eds) MonTI 3 Women and Translation: Geographies, Voices and Identities, 9-28.

_ (2014) 'Sex and Translation: On Women, Men and Identities', Women's Studies International Forum 42, 104-110.

Tao, Tiezhu 陶铁柱 (trans.) (1998) 第二性（全译本） [ The Second Sex (complete translation)], Beijing: 中国书籍出版社 [China Books Publishing House].

Wang, Youqin 王友琴 and Qiu Xichun 邱希淳, et al. (trans.) (1988) 女人是什么 [ What is Woman], Beijing: 中国文联出版公司 [China Federation of Literary and Art Circles Publishing Corporation].

Xiao, Hui 肖慧 (2009) ‘《阴道独白》的跨国旅行’ [Transnational Voyage of The Vagina Monologues], 妇女研究论丛 [Collection of Women's Studies] 2, http://qkzz.net/ article/8ad0ae2e-736c-45a9-b5al-d007c6602c4e.htm (last accessed on 7 June 2009). 
Yu, Rongjun 喻荣军 (trans.) (2003) 阴道独白 [The Vagina Monologues], http://bbs. sachina.pku.edu.cn/archiver/tid-3681.html (last accessed on 27 December 2006).

Zheng, Kelu 郑克鲁 (2011) 《第二性》 [The Second Sex]. Shanghai: 上海译文出版社 [Shanghai Translation Publishing House].

Zheng, Kelu 郑克鲁 (speaker) and Cao Qian 曹倩 (writing-up) (2010) ‘存在主义女作家 波伏瓦的《第二性》' [Existentialist Female Writer Beauvoir's The Second Sex], 世界文 学评论 [The World Literature Criticism] 1: 11-13. 


\section{Index}

adaptation 14, 63, 70, 73-6, 112, 128, 179,186 ; adaptation theory 38

addition 14, 21, 25, 70, 75-6, 111, 120, $127-9,186$

age $11,60,69,83-4,91,96-8,125$,

$141,148,173-4,178$

agency $20-1,23$

agenda $3,20,27$

Agorni, Mirella 31

Ai, Xiaoming 13-14, 42, 70-1, 73-6, 108-9, 110-12, 114, 116, 118-24, $127-9,132,143-53,170,172-3$, $175-7,186-7,191$

Altman, Meryl 133

ambivalence 6

amplification 14, 69, 86-8, 95, 103, 128, $153-4$

analysis $8,10-14,25-6,40,42,44,59$, 61-2, 64, 66-8, 71, 84, 90, 96-8, $106,115-16,133,142,171,185-7$, 190

analytical category 5-6, 10, 33, 190

Andone, Oana-Helena 31

andro-texts 4

approaches 5, 13, 21, 24, 26, 30, 33, 117

Arrojo, Rosemary 29

attention 1, 4-5, 10-11, 28, 30, 35, $37-40,44,62,67-8,75-6,83,89$, $95,102,112,126,129,133,137$, $143,149,161,163,177,190,193$ attenuation 14, 90, 103, 128-9, 153, 159

attitude $4,7,10,12,103,106,125$, $138,140-1,149-50,153,168,173-6$, 186 attribute 2

author-centred strategies 23

back-translation 13-14

Baer, Brian James 33, 175

Bair, Deirdre 60, 83

Baker, Mona 4

Baldick, Chris 4

Banting, Pamela 29

Barlow, Tani E. 6

Barry, Peter 4

Bartky, Sandra Lee 84, 94-6

Bassnett, Susan 1, 29, 31

Baumgardner, Jennifer 27

Beasley, Chris 3

Beauvoir, Simone de 2-4, 11-13, 33, 59-66, 68, 83-4, 87, 91, 95-8, 102, 106, 114-16, 132-3, 135, 137, 141, 168-9, 171, 178-9, 189, 192

Bell, Susan E. 69-70, 107, 142

Belsey, Catherine 106

bilingual translation $14,107-8,111-12$, $114,128-9,136,153,186$

Billiani, Francesca 158

biology 26, 59, 61, 64, 140

Bird, Phyllis A. 29

body $5-6,33,38,41-2,44,75,84$, $86-7,89,90-3,95-6,114,120,123$, $126,135,142-3,147$; female 5,8 , $10-13,28,42,59-60,70,83-4$, 86-91, 94-6, 103-4, 106, 120, 132, $144,153,168,177-8,185-6,188$, 190, 193; man's 89; woman's 5,75 , 89; body work 68

Bogic, Anna 63

Braun, Virginia 68, 113, 142 
Brossard, Nicolas 25

Bu, Wei 69-70, 151

Burger, Richard 117, 159-60, 164-5, $173-4$

Butler, Judith 3, 6, 32, 84

Canada 1, 5, 20, 37

Canadian: feminist translation 2, 20, $25,31,37,185-6$; feminist translation strategies $11,185,187$; feminist translation theory 37,41 ; feminist translation approaches 44 ; feminist translators 44

canon 23

Cantonese 5, 152

Capperdoni, Alessandra 31

Castro, Olga 33

categories $6,10,22,24-5,27,132,189$

censorship 6, 8-13, 22, 33-4, 59, 76, 153, 158-63, 166-9, 172, 175-9, 185-7, 191, 193; post-publication 160; pre-publication 160; self-censorship 6 , $22,153,160,166,172,175,178,187$ challenge $1,5,8,107,112,161$

Chamberlain, Lori 5, 29

Chan, Red 159-60

Chang, Nam Fung 159-62

change $14,21,62-4,70,72,76,84,91$, $96,148,151,160,167,174,191$

Chen, Cangduo 13, 71, 72, 74-5, 107, $112,114,116,120-8,136,142-5$, $147-9,151,153,187$

Chen, Chapman 34

Chen, Lin 41

Chen, Tina Mai 6

Chen, Xiaoli 64, 192

Chen, Xiaoping 162, 164-5

Cheng, Sea Ling 70, 106, 186

China $1-3,6-13,21-2,26-31,34-8$, 40-4, 64-7, 70, 72-3, 75, 108-10, $116-17,132-3,151-3,158-79,185$, 187-8, 191-3; within 34; outside 2, 6 , 11, 21-2, 27-9, 34, 44, 174, 185; within and outside $6,11,20,22,27$, $44,174,185$

Chinese: custom 15, 117; women 6-7, 74, 116-17, 169-71, 179, 192; women translators 38 ; women writers 73,171
Chou, Wah-Shan 175

circulation 9, 21, 41, 177-9

Cixous, Hélène 4-5, 32

clitoris $142-5$

Comparative Literature Studies 33

Conboy, Katie 8, 10, 106, 187

concept(s) 1-3, 5, 32, 35, 60, 63, 75, 132

connotation $22,87,90,137,140,149-50$, 154

construction 2, 5-6, 8; cultural 8; social 2; social constructionism 189

context 1-2, 7, 11-12, 14, 20, 23, 26-9, $34,39,41-2,44,61,65,71-2,74-6$, 87-8, 90, 95, 104, 109-11, 115, 122, $126,128,135,137,142,145,158$, $171,176,178,185-6,188,190-3$

contextual meaning $24,88,90-2,95,97$, $115,121-2,145,186$

controversy $6,11,30,67,73,142,166$, 176,178

convention $1,5,127,166$

conventional: translation 25; (translation) strategies 26; translation theory 26

Cooper, Christine M. 69-70, 141, 146, 151,186

Cordero, Anne 29

corrective measures 22

Coward, Ros 22, 27

creative writing 26,73

creativity $20,25,107,112$

criticism 5, 21, 26, 30, 61-4, 69, 71, $161,173,191-2$

Cui Zi'en 174-5

Cultural Revolution 6-7, 64, 162-4, 170, 173,175

cultural: barriers 20 ; construction 8 ; difference 8,76 ; formation 5 ; mediators 10 ; studies 30 ; transfer 30 ; turn 1,10

culture $1-3,5,8-9,11,20,23,26,28$, $31-4,42,44,63,69,74,84,86,90$, $94,101,106,114,116,124-5$, 137-8, 140, 144, 149-52, 159-61, $165,169,171-2,174,177,186-8$, 193; Chinese 86, 90, 94, 114, 116, 137, 140, 149-50, 160-1, 174, 188; English 138; patriarchal 84, 101, 106, 124-5, 171-2, 177; target 1, 63, 186; source 1, 187; Western 165 
Dai, Jinhua 64, 162

Darbelnet, Jean 25

deletion 25, 41, 61, 65, 67, 76, 159, 168

Demarco, Marisa 8, 68, 69

description $8,10-12,33,41,66-7$, $72,84,87,98,133,142,151,153$, $159-61,164,166,168,172-3,175$, 178, 187-8, 193; detailed 160; erotic 72, 142, 164, 168, 172, 187; explicit 159-61, 168, 173, 175; graphic 8, $151,153,187$; objective 87,98 ; sexual 8, 41, 160-1, 166, 178, 187, 193; desire 5-6, 68, 73, 90, 134, 139, 150, 163, 166, 177-8; political 6; sexual 73, $90,134,177$

development $7,11,28,30-3,36,38,40$, $44,60-1,64,84,88,91-2,96,150$, $152,163,166-8,171,185,189-90$, 192-3

difference $2-3,5,7-8,10,12-14,21-3$, $25,31-2,42-3,62-3,72-3,76,87-9$, 93, 95-6, 99, 102-3, 114, 118-20, $124-6,129,142-3,148,151,153-4$, $170,173,177,185-6,188,190,192$; feminine 5 ; gender 7,170 ; ideological 14; language 62, 112; physical 3; sex 2 ; sexual 2; translation $10,42,153-4$ difficulty 8, 96, 111, 136, 138-9, 153, 169 director 13, 73, 133, 152, 162, 165 discourse 1, 5, 8, 29, 31-2, 42, 69, 73, 120, 177, 188, 192; dominant 5, 177; feminine 42 ; patriarchal 120

discursive: solution 6 ; spaces 5

Dodson, Betty 113, 142-3

domestication 14, 72, 75, 116, 128; see also localising

Douglas, Susan 27

Drury, Russell 159, 166

écriture feminine 4,32

editor $6,9,63,65-6,158,160,162$, $165-6,168,187$

Egeland, Cathrine 27

emergence 11, 20, 28, 30, 34, 36-7

Ensler, Eve 2, 68-70, 72, 74, 106-7, $109,110-15,119-21,125,128$, $141-2,144-5,147-9,151,176,186$ equivalence $1,35,38,186$ eroticism 8, 83, 96, 106, 159 essentialism 6, 13, 185, 188-9, 191

Evans, Harriet 8, 59-60, 177

Evans, Ruth 59-60

Fallaize, Elizabeth 61, 83, 168, 178

Farrer, J. 117

Federici, Eleonora 2, 32-3

Felstiner, Mary Lowenthal 84

female: appearance 103 ; body 5,8 , $10-13,28,42,59-60,70,83-4$, 86-91, 94-6, 103-4, 106, 120, 132, $144,153,168,177-8,185-6,188$, 190, 193; heterosexuality 10-13; masturbation $8,69,142-6$; same-sex sexuality 10; same-sex love $8,10,173$; same-sex relationships 174; sexual desire 177; sexuality $8,10-13,28,42$, 59, 70, 83-4, 104, 106, 132, 144, $168,177,185-6,190,193$

feminism 1-7, 10, 12-13, 20, 22, 24, 26-9, 30-2, 36-7, 42, 44, 59, 61, 66-71, 73, 83-4, 103, 106, 111, 118, $121-2,132-3,142,150,163,167$, 169-71, 175, 185, 188-9, 191-3; American 169; Anglo-American 70; Chinese 2-3, 6-7, 171, 185, 188, 192; Chinese-styled 7; French 20, 29; international 7,29 ; new 4 ; oppositional 7 ; socialist 6,61 ; 'softer' 7; Western 3, $6-7,10,12-13,37,66,71,133,167$, $171,185,188,191-2$; three waves 3-4, 27-8, 32, 188; see also feminist and feminists

feminist: agenda 20; consciousness 7, 20; meaning 22 ; position $2,10,41$; perspective 11-12, 42, 44, 102, 133, 185; interventions 22, 104, 186-7; text 20, 24-5, 31, 36, 129, 188, 193; translator $5,20-2,24,26,31,37,44$; writing 106; work $2,20,44,69,72$, $102,167,171,185,188$; translation $1-2,4-6,11,13,20-32,34-44,71$, 185-7, 190, 193; see also feminism and feminists

feminist-identified translation 22 feminists 3-6, 27-8, 69, 73, 121, 192; American 2; Chinese 170; Chinese diasporic 3; French Canadian 20; radical 5,132 
Fixmer, Natalie 27

Flotow, Luise von 1-2, 5-6, 10-11, 20-6, 29-33, 40-1, 44, 61, 83, 106, 172, 189-91

Forster, Penny 83, 168, 172

Fuchs, Jo-Ann P. 96, 132

Fullbrook, Edward 60

Fullbrook, Kate 60

Ge, Xiaoqin 40

gender $2-10,12-13,22-4,27-33,35-6$, $38,40-4,60,73,75,84,86,90$,

$94-6,106,117,128,139,145,147$, 169-71, 177, 179, 185, 187-93;

perspective $30,40,43$; studies 30,33 , $73,188,192$; performativity 3,6

Gender and Language 33

Genette, Gérard 22, 118

Gillis, Stacy 4

Glover, David 2

Godard, Barbara 20, 25, 29, 31

Guild, Elizabeth 5

Hall, Kim Q. 69-70, 125

Hammers, Michele L. 68-9, 126, 142-3

Han, Jiaming 37

Han, Ziman 41, 160, 187

Harvey, Keith 33

Hawthorne, Melanie C. 2, 83

He, Ping 6

Henitiuk, Valerie 30

heterosexuality $69,84,96,98,102,142$, 177

hijacking 21-2, 26

Ho, Loretta Wing Wah 132, 174

homosexuality $12,33-4,65,132-3,138-9$, $141,153,166,168,171,173-5,187$

Huang, Lin 7, 167, 169, 171, 192

Hung, Eva (Kong, Huiyi) 35, 37-9

identity $6-7,24,30-1,33,43,84,128$, 136, 139, 168, 173, 189-91, 193

Jeffreys, Elaine 8

Jiang, Xiaohua 41

Jiang, Xinyan 28

Jones, Ann Rosalind 5, 106

Journal of Feminist Studies in Religion 29

Jun, Tang 34-5
Kahn, Joseph 160, 175-6, 178

Kaplan, Cora 2

Keefe, Terry 60-1

Keenaghan, Eric 33

Ko, Dorothy 6-7

Krontiris, Tina 29

Kruks, Sonia 59

Kuhiwczak, Piotr 158, 175

Larkosh, Christopher 6, 32-3

Lefevere, André 1

Leonardi, Vanessa 2, 31, 33

lesbian 4, 12-13, 34, 42, 65, 71, 84, 96, $106,109,132-9,142,149-51,168$, $173-4,187,190$

lesbianism 8, 10, 12-13, 34, 60, 69, 83, 132-3, 135, 137-8, 140-1, 147, 150, $153-4,158,168,173-4,185-8,193$

Leung, Helen Hok-Sze 174, 188

Levine, Suzanne J. 29

Li, Bo 32,34

$\mathrm{Li}$, Jingrui 163-8, 177

Li, Qiang 13, 64, 66, 84, 143

Li, Xiaojiang 3, 170

Li, Yinhe 132, 174-6

Liao, Qiyi 37-8, 40

literal translation 14, 24, 66, 71-2, 89-90, 92, 97, 103, 116, 121, 128-9, $138,145-6,151,153-4,186,189$

Littau, Karin 31

Liu, Dalin 132-3

Liu, Junping 41

Liu, Lydia H. 6, 192

Liu, Shengquan 164-6, 172

Liu, Xiantao 166

lived experience $83,89,91,94,103-4$, 155

localising 14, 72, 75, 116, 126, 128-9, $151-2,154,175,191$

Longguang, Lu 132-3

Lotbinière-Harwood, Susanne de 20-1, 29,31

Lung, Rachel 8, 159

Luo, Ting 169

$\mathrm{Lv}$, Pin 73

Ma, Audrey 34

Maier, Carol 11, 21, 23-4, 29-31

manhandle 87; see also womanhandle 
Mann, Susan L. 170, 174

map 2, 33, 190

Massardier-Kenny, Françise 11, 21-4, 26, 29,31

McElroy, Wendy 69, 113, 147

McMillan, Joanna 9, 174, 187

mediation 1,5

mediator 10, 193

meta-discourse $23,25,27$

metatext 22, 118

Mezei, Kathy 29

Mills, Sara 106

Min, Dongchao 4, 6-7

misogyny 106, 124-5, 127

mistranslation $12-13,37,61,65,89$, $93-5,102,104,129,139,154,159$, 186,189

Moberg, Åsa 97

Moi, Toril 4, 6, 22, 27, 61, 63-4, 83, $106,167,172$

Moore, Jane 106

$\mathrm{Mu}$, Lei 37-8, 40-1, 43

Munday, Jeremy 1, 31, 34, 36, 186

Munford, Rebecca 4

Mwangi, Evan 31

Nan, Shan 13, 64-5, 83, 133, 168

Niranjana, Tejaswini 5, 30

Nord, Christian 170

Olson, Loreen N. 27

omission 14, 61, 63, 75, 111-12, 128-9, $153-4,158,161,167$

over translation 22

Palmary, Ingrid 32

Pan, Suiming 8, 164

paratexts 22, 118

paratranslation factor 11, 63

paratranslator 63

Parshley, Howard M. 11, 61-3, 68, 95, 161

Patterson, Yolanda Astarita 60-3, 67, 178

Pearce, Lynne 106

People's Republic of China 6, 65, 165-6, 171,173

Pilardi, Jo-Ann 60-1, 66

post-feminism 4

post-feminist work 4

prefacing and footnoting $21-3$
Price, Janet 106

prostitute $5,65,67,132,142,150,168$,

171, 187; see also sex worker

prostitution $60,65,153,158,164,168$, 187

publication $15,30,34-5,40,61-2$,

64-5, 68, 162, 164-8, 177; Chinese

15; obscene 162, 165-6, 168

publisher $9,41,62-7,71,83,132,158$, $160-8,172,177-9,187$

Qiu, Xichun 13, 65, 83, 133, 168

queer 33-4; theory 6, 32, 189-91;

approaches 13, 32, 189; studies 177,

188

reception $3,7,9-10,12-14,32,39$,

$111,126,129,152-3,168-9,171-2$,

$175,178,185,187-8,192-3$

Reimóndez, María 31-2

Renshaw, Sal 147

repetition $14,25,39-40,44,87,89$,

$103,128-9,149,153-4$

representation $6,8,11,29-30,60,129$, 133

reversion 14,103

rewriting 10-12, 21, 72, 106, 111, 142, $153,158,191$

Richards, Amy 27

Robinson, Douglas 29

Ruan, Fang-fu 8

same-sex: behaviour 173; love $8,106,138$, 173 (female 141, 173; male 173); sexual contact 174

Sang, Tze-Ian D. 8, 174, 177

Sang, Zhuying 13, 64-5, 83, 133, 168

Santaemilia, José 2, 10, 31-3, 158, 186, 189-91

Schaeffner, Christina 32

Schaffer, Kay 7

semantic translation $14,35,78,89-90$, $92,103,128-9$

semiotic translation $14,144,154$

sex $2-3,7-10,21,28,31,33,59,61-2$, $64-5,67,72,83,85,90,132-3,135$, $142,147-9,151-3,158-9,160-2$, 164-5, 167-72, 174-8, 185, 187-9, 191-2; organ 86; worker 132, 175 
sexual: abuse $68,70,103,119$; attraction 135; autonomy 132; harassment 97 , 128; implication 90, 140, 172; object $5,7,87$; oppression $8,123,132,188$; organ $41,68,86-7,90,98,112,137$, $140,144,160,176$; orientation 69, $132,147,150$; pleasure 42, 126, 139, 140-1, 144, 152, 165, 177; repression $144,152,164$; violence $68,75,106$, $119,125,147,165$

sexuality $4-6,8-13,28,32-4,38,41-2$, $44,59,65,68-70,75,83-4,88$, 96-7, 102-4, 106, 113, 120, 125, $127,132,138-40,142-6,149,152-3$, $157-8,167-9,172,175,177-8$, $185-7,190,193$

Shen, Ke 66, 68

Shildrick, Margrit 106

Showalter, Elaine 4, 22, 27

Shread, Carolyn 31

Sigley, Gary 8, 117, 175

Simon, Sherry 1, 20-2, 29-31, 40-1, $60-1,63,87,132-3,172,188$

Simons, Margaret A. 29, 59-61, 63, 132-3, 172

Snyder, R. Claire 4, 27-8

Song, Xianlin 7

Spakowski, Nicola 3, 7

Spencer, Aida Besançon 31

Spivak, G. C. 29,188

Spurline, William J. 33-4

subculture 132

Sun, Yifeng 30, 34-6, 40

supplementing 21-3

Susam-Sarajeva, Şebnem 31

Susan M. Reverby 69-70, 107, 142

Sutton, Imogen 83, 168, 172

Tang, Zhen 140

Tao, Tiezhu 13, 64-6, 84, 133, 166, 168 Tessera 29

text: feminine 4; source 11, 13-14, 21-3, 25-6, 41-2, 64, 66, 70-1, 73, 86, 88-98, 101-3, 109, 112, 114-16, 118-24, 127-9, 134-42, 144-6, 148-51, 153-4, 172, 175, 178, 185-8; target 14, 23, 25-6, 186 translation: Chinese 2, 7, 9-14, 27, 34-5, $37,39,41-2,59,63-8,71-2,83,86$,
$90,106,108,112,114,132-4,141$, $144,151,158-63,165-8,171-2$, 177-8, 185-7, 189-90, 193; effect 10, 87, 133, 185, 191, 193; English 11, 20, 33, 49, 59, 61, 63-4, 66-8, 83, 172,193 ; practice $5,22-3,30,35$, 40-1, 44; strategy/ies 2, 10-12, 14, $20-7,29,31,37-8,71,83,87,103$, $114,121,128-9,153-4,185-8$; theory $25-7,30,35,37-8,41-2$ translation publishing $158,162-4,166-8$ translation publishing industry 11-12, 158,185

Translation Review 29

translation studies 1-2, 5-6, 9-10, 13, 21, 29-38, 40-1, 43-4, 63, 68, 160, 185, 188-90, 193; Chinese 6, 10, 35, 37; Chinese feminist 2, 6, 10, 34-5, 39, 44; feminist 2, 5-6, 11, 13, 21, 27-32, $34,36-8,40-4,185,189-90,193$ translator-centred strategies 23 transliteration 14, 117, 153, 186

vagina $2,8,21,59,68-72,74-5,83$, $101,106-14,117-22,124-8,132$, $136,141-4,146-8,150,158,172$, $175-7,179,185-6,191$

Vazquez, Olga Castro 63

Vinay, Jean-Paul 25

Vintges, Karen 59-60, 96

Wallmach, Kim 11, 20-1, 25-6, 30-1

Wang, Fang 169

Wang, Ning 35-6

Wang, Youqin 13, 65, 83, 133, 168

Wang, Zheng 3, 6-7, 171

Wang, Zhisong 160

West, Kevin 33

Western: feminist translation 1 ; feminist translation practice and theory 35,38 , 40; feminist translation theory 38 ; feminist translation practice 38

Wheeler, Anne-Marie 31

Widerberg, Karin 2

Wittig, Monique 132

womanhandle 87, 102

Women's Studies International Forum 33

Wong, Lawrence Wang-Chi (Wang Hongzhi) 37 
Wood, Julia T. 27

word play/wordplay 5, 20, 22, 109

works: American feminist 171; Western feminist 167

writing: body 8 ; creative 21,73 ; experimental 5 ; experimental feminist $4-5,21$; female 43; feminine 4; feminist 5, 43, 106, 192; innovative 20; masculine 4; phallogocentric 4; productive 21 ; radical feminist 4 ; women's 4-5, 29, 44, 192

Wu, Xusheng 163, 165-6

Xiao, Hui 75, 152, 192

Xie, Tianzhen 37, 162

Xinran 8

$\mathrm{Xu}$, Baoqiang 40
$\mathrm{Xu}$, Feng 3, 6-7

$\mathrm{Xu}$, Jun 66, 68

Xu, Lai 41

Yan, Fu 26

Yu, Rongjun 13, 42, 72-4, 76, 108-9, 112 , 114, 118-28, 142-5, 147-51, $172,175-7,186-7,191$

Yu, Zhongli 34

Yuan, Wei 40

Yue, Ming-Bao 31

zero translation $14,108,111,128-9,186$

Zhang, Jinghua 41

Zhang, Longxi 26, 163-4

Zhang, Wenxian 159

Zheng, Kelu 68, 163, 189 